UNIVERSIDADE DE SÃO PAULO

FACULDADE DE FILOSOFIA, LETRAS E CIÉNCIAS HUMANAS

DEPARTAMENTO DE HISTÓRIA

PROGRAMA DE PÓS-GRADUAÇÃO EM HISTÓRIA SOCIAL

\title{
TACIANA WIAZOVSKI
}

\section{Cultura em Comentário \\ Uma revista de Cultura e Resistência}

(1960-1973)

Versão corrigida

São Paulo

2011 
TACIANA WIAZOVSKI

\section{Cultura em Comentário Uma revista de Cultura e Resistência (1960-1973)}

Versão corrigida

Tese apresentada ao Programa de Pós-Graduação em História Social, do Departamento de História da Faculdade de Filosofia, Letras e Ciências Humanas da Universidade de São Paulo, para obtenção do título de Doutor em História.

Orientadora: Profa. Dra. Maria Luiza Tucci Carneiro

São Paulo

2011 
WIAZOVSKI, T. Cultura em Comentário - Uma revista de Cultura e Resistência (1960-1973)

Tese apresentada à Faculdade de Filosofia, Letras e Ciências Humanas da Universidade de São Paulo para obtenção do título de Doutor em História.

Aprovado em:

Banca Examinadora

Orientadora: Prof. Dra. Maria Luiza Tucci Carneiro (Departamento de História FFLCH/USP)

Julgamento:

Assinatura:

Prof. Dra. Jajja Rifka Berezin (USP)

Julgamento:

Assinatura:

Prof. Dra. Elizabeth Cancelli (USP)

Julgamento:

Assinatura:

Prof. Dr. Márcio Selligman (UNICAMP)

Julgamento:

Assinatura:

Profa. Dra. Betty Bernardo Fuks (PUC/RJ)

Julgamento: Assinatura: 


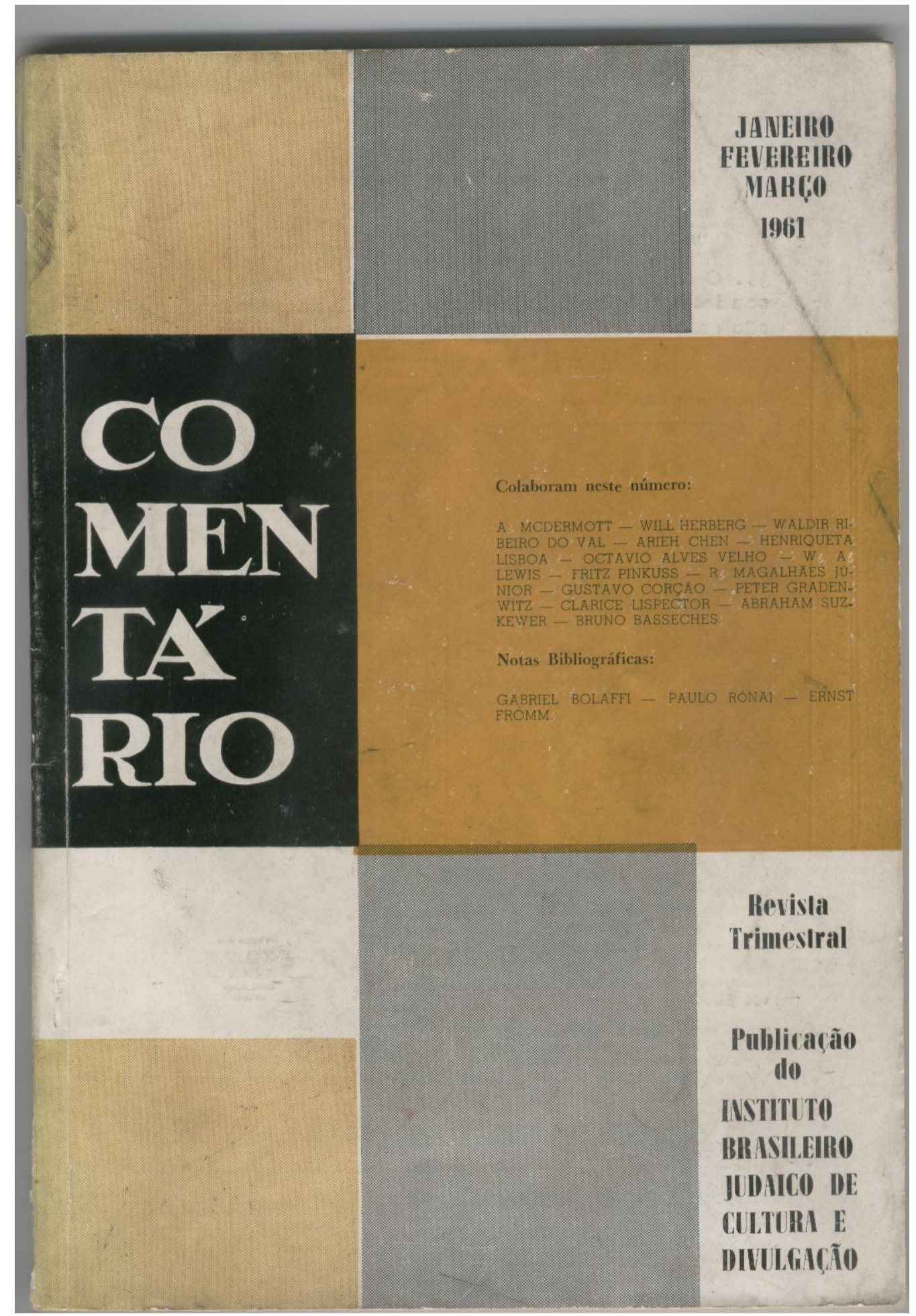

1 - Capa da revista Comentário, Ano II, n.1, 1961. 
Aos imprescindíveis

Vasco, Guiomar, Rodrigo e Sofia. 


\section{AGRADECIMENTOS}

À querida Profa. Dra. Maria Luiza Tucci Carneiro, a quem devo a minha formação em História, tendo me orientado desde a Iniciação Científica e Mestrado, servindo-me de referência, apoiando-me sempre, contribuindo de maneira fundamental para o meu crescimento intelectual;

Aos amados pais Vasco e Guiomar, minha filha Sofia e companheiro Rodrigo, pelo amor e ajuda em tudo, sem eles seria impossível a realização deste trabalho;

Ao querido Prof. Dr. Bóris Kossoy, pelo sorriso gentil, carinho e encorajamento;

À querida Profa. Dra. Elisabeth Cancelli, pelas sugestões e observações experientes;

À Profa. Dra. Ana Maria Vicentini de Azevedo, minha analista, por me escutar durante todo o período em que desenvolvi esta pesquisa e por me acolher desde 2007 no trabalho que desenvolve dedicado ao ensino e à transmissão da psicanálise;

Ao estimado Prof. Dr. Jacó Guinsburg, por me receber e fornecer informações tão preciosas para o desenvolvimento deste trabalho;

Ao estimado Prof. Dr. Boris Schneiderman, por conversar comigo e por sua doce figura;

À Sra. Lisette Pernidji por gentilmente me receber em sua casa e Sergio I. Eskenazi Pernidji por colocar à minha disposição todos os números que possui em seu arquivo da revista Comentário;

À amiga Márcia Yumi Takeuchi (in memoriam), que se foi cedo demais para quem ficou e desejava ainda mais dela ver e prestigiar. Colega sempre presente nos assuntos da academia e da amizade. Éramos cinco, agora quatro amigas que periodicamente almoçam juntas e dividem aflições, afinidades, caminhos de pesquisa e de vida;

Às amigas que ficaram: Mariana Cardoso dos Santos Ribeiro, Ismara Izepe de Souza e Gláucia Rodrigues Castellan;

Aos queridos amigos do Arqshoah, pelos bons momentos de descontração necessários para lidar com o pesado tema do Holocausto que durante alguns meses dividi com eles;

À Camila Werner, amiga e "consultora para assuntos diversos" com quem conversei muitas vezes sobre este trabalho e teve disposição para ouvir;

Ao Departamento de História da Faculdade de Filosofia, Letras e Ciências Humanas da Universidade de São Paulo, pela oportunidade de realização do curso de doutorado;

Ao Arquivo Histórico Judaico Brasileiro, por colocar à minha disposição o seu acervo e pela cordial atenção de seus funcionários;

À Fundação de Amparo à Pesquisa do Estado de São Paulo, pela concessão da bolsa de doutorado e apoio financeiro para a realização de parte desta pesquisa. 
"Por ora, gostaria de me limitar a indicar que, no que se chama globalmente um Comentário, o desnível entre texto primeiro e texto segundo desempenha dois papéis que são solidários. Por um lado permite construir (e indefinidamente) novos discursos: o fato de o texto primeiro pairar acima, sua permanência, seu estatuto de discurso sempre reatualizável, o sentido múltiplo ou oculto de que passa por seu detentor, a reticência e a riqueza essenciais que lhe atribuímos, tudo isso funda uma possibilidade aberta de falar. Mas, por outro lado, o Comentário não tem outro papel, sejam quais forem as técnicas empregadas, senão o de dizer enfim o que estava articulado silenciosamente no texto primeiro. Deve, conforme um paradoxo que ele desloca sempre, mas ao qual não escapa nunca, dizer pela primeira vez aquilo que, entretanto, já havia sido dito e repetir incansavelmente aquilo que, no entanto, não havia jamais sido dito."

FOUCAULT, Michel. A Ordem do Discurso. Trad. Laura Fraga de Almeida Sampaio. São Paulo Edições Loyola, 1996, pp 24 e 25. 


\section{RESUMO}

\section{WIAZOVSKI, T. Cultura em Comentário. Uma revista de Cultura e Resistência}

(1960-1973), 2011. Tese (Doutorado). Faculdade de Filosofia, Letras e Ciências Humanas - Universidade de São Paulo, São Paulo, 2011.

Este estudo reconstitui a trajetória e a contribuição intelectual de Comentário (19601973), revista financiada pelo American Jewish Committee (AJC) que seguiu o modelo da americana Commentary criada quinze anos antes. A publicação reuniu proeminentes nomes da cultura nacional e internacional da década de 1960. Procuramos pelas origens da revista nos Estados Unidos por meio de sua relação com a empreitada cultural norte-americana durante a Guerra Fria, considerando que tal publicação se dizia "aberta ao amplo debate cultural". Através da recuperação de partes deste debate avaliamos o papel do intelectual na cultura. A revista possibilitou uma análise da postura intelectual judaica no período pós-Holocausto, momento em que se ponderou o contexto internacional do alinhamento de Israel ao Ocidente, os processos antissemitas da União Soviética e a ruptura das relações entre Israel e União Soviética em 1953. Comentário favoreceu o estudo da inserção da comunidade judaica no contexto cultural e político brasileiro da década de 1960 e primeiros anos da década de 1970, abrangendo o golpe de 1964 e os anos de maior repressão política as ideias no Brasil. Nossa hipótese é de que a revista Comentário ofereceu, por seu potencial crítico e inovador, um espaço privilegiado para a intelligentsia judaica e não judaica no Brasil pensar as questões políticas e culturais de seu tempo no universo das ações que se desenvolveram no pós-guerra a partir da criação da Organização das Nações Unidas (ONU), sobretudo através da Organização Educacional, Científica e Cultural (UNESCO) e do conceito de Direitos Humanos. Consideramos o impacto destes valores na cena cultural brasileira, sua relação com a comunidade judaica radicada no Brasil e com o espaço da classe dirigente. A revista atuou como um espaço de divulgação dos estudos sobre antissemitismo, etnicidade, racismo e intolerância gerando linhas de pesquisas que têm hoje a sua atualidade. Através do inventário biográfico de alguns colaboradores da revista e sua produção, resgatamos a história de uma importante geração de intelectuais.

PALAVRAS-CHAVE: Antissemitismo, Cultura Brasileira, Intelectual, História Social, História Política, Judaísmo, Guerra Fria. 


\begin{abstract}
This study reconstructs the history and the intellectual contribution of Comentário (1960-1973), a magazine funded by the American Jewish Committee (AJC), which followed the model of the American Commentary established fifteen years earlier. The publication brought together prominent names in national and international culture of the 1960s. We seek the origins of the magazine in the United States through its relationship with cultural undertaking U.S. during the Cold War, considering that such a publication called itself "open to broad cultural debate." Through the recovery of parts of this debate we evaluate the role of intellectual culture. The magazine has enabled an analysis of Jewish intellectual position in the post-Holocaust, when it weighed the international context of the alignment of Israel to the West, the processes of antiSemitic Soviet Union and the rupture of relations between Israel and the Soviet Union in 1953. Comentario favored the study of the insertion of the Jewish community in the Brazilian political and cultural context of the 1960's and early 1970's, covering the 1964 coup and the years of greatest political repression in Brazil ideas. Our hypothesis is that the magazine Comentário offered by its critical and innovative potential, a privileged space for the Jewish and non Jewish intelligentsia in Brazil think the political and cultural issues of his time in all the actions that have developed in the postwar Since the creation of the United Nations (UN), especially through the United Nations Educational, Scientific and Cultural Organization (UNESCO) and the concept of Human Rights. We consider the impact of these values in the Brazilian cultural scene, its relationship with the Jewish community living in Brazil and the space of the ruling class. The magazine served as a forum for dissemination of studies on anti-Semitism, ethnicity, racism and intolerance causing lines of research that has its relevance today. Through the biographical inventory of some employees of the magazine and its production, we rescued the story of an important generation of intellectuals.
\end{abstract}

KEY WORDS: Antissemitism, Brazilian Culture, Intellectual, Social History, Political History, Judaism, Cold War. 


\section{ILUSTRAÇÕES}

1 - Capa da revista Comentário, Ano II, n. 1, 1961...................................... 4

2 - “llustração especial para Comentário, de Cândido Portinari”, em: Comentário, Ano I, n. 1,1960 , p. 69 127

3 - Fotografia do artista Lasar Segall, São Paulo, 1943, em: Comentário, Ano III, n. 3, 1962, entre as pp. 224-225. 128

4 - "Sobreviventes", 1941, óleo, de Lasar Segall, em: Comentário, Ano III, n. 3, 1962, entre as pp. 224-225. 129

5 - "Guerra”, 1942, óleo, de Lasar Segall, em: Comentário, Ano III, n. 3, 1962, entre as pp. 224-225 129

6 - Desenho da série "Guerra”, 1941, bico de pena, de Lasar Segall, em: Comentário, Ano III, n. 3, 1962, entre as pp. 224-225. 130

7 - "Pogrom", 1936-37, de Lasar Segall, em: Comentário, Ano III, n. 3, 1962, entre as pp. 224-225 131

8 e 9 - “Judeu em prece”, 1927, água forte e "Êxodo", 1947, óleo, de Lasar Segall, em:

Comentário, Ano III, n. 3, 1962, entre as pp. 224-225 132

10 - “Mães Errantes”, 1941, bronze, de Lasar Segall, em: Comentário, Ano III, n. 3, 1962, entre as pp. 224-225 133

11 - “Crianças com rabino”, 1908, desenho a lápis, de Lasar Segall, em: Comentário,

Ano III, n. 3, 1962, entre as pp. 224-225. 133 
TABELAS

Comentário: Autores Nacionais.

165

$2-$

Comentário: Autores Internacionais.

$3-$

Comentário: Diretoria, Conselho Editorial, Secretaria de

Redação e IBJCD.

$4-$ Comentário: Seção "Sôbolos rios que vão..." - cultura judaica excertos

213 


\section{SIGLAS E ABREVIATURAS}

$\mathrm{ABL}$ - Academia Brasileira de Letras

AHJB - Arquivo Histórico Judaico-Brasileiro

AJC - American Jewish Committee

AJYB - American Jewish Year Book

APESP - Arquivo Público do Estado de São Paulo

$A R I$ - Associação Religiosa Israelita (RJ)

BFFLCH/USP - Biblioteca da Faculdade de Filosofia, Letras e Ciências Socias da

Universidade de São Paulo

BCEJ/USP - Biblioteca do Centro de Estudos Judaicos da Universidade de São Paulo

BMMA/SP - Biblioteca Municipal Mario de Andrade

BNA/RJ - Biblioteca Nacional do Rio de Janeiro

CAPH/USP - Centro de Apoio à Pesquisa Histórica "Sérgio Buarque de Holanda"

$\mathrm{CIA}$ - Central Intelligence Agency

CEJ/USP - Centro de Estudos Judaicos da Universidade de São Paulo

CIP - Congregação Israelita Paulista

CCF - Congress for Cultural Freedom

CJR - Contemporary Jewish Record

DEOPS/SP - Departamento Estadual de Ordem Política e Social de São Paulo

DAESP - Divisão de Arquivo do Estado de São Paulo

DHBB - Dicionário Histórico Biográfico-Brasileiro

Fierj - Federação Israelita do Estado do Rio de Janeiro

Fisesp - Federação Israelita do Estado de São Paulo

IEB/USP - Instituto de Estudos Brasileiros/Universidade de São Paulo

IJBCD - Instituto Judaico Brasileiro de Cultura e Divulgação

IJACI - Instituto Judio Argentino de Cultura e Informação

JCA - Jewish Colonization Association

LEER/USP - Laboratório dos Estudos sobre Etnicidade, Racismo e Discriminação da Universidade de São Paulo

PROIN - Projeto Integrado Arquivo Público do Estado/Universidade de São Paulo

UNESCO - Organização Educacional, Científica e Cultural das Nações Unidas 


\section{SUMÁRIO}

\section{Cultura em Comentário \\ Uma revista de Cultura e Resistência}

(1960-1973)

RESUMO

ABSTRACT

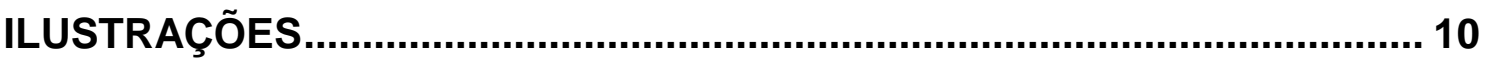

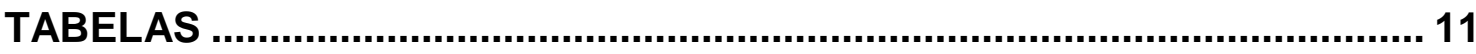

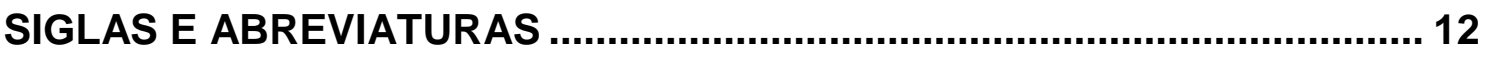

INTRODUÇÃO

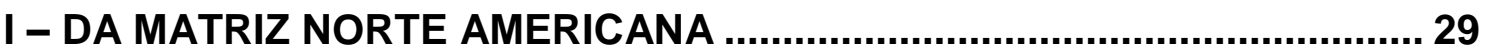

1.1 -COMMENTARY: UMA INICIATIVA DO AMERICAN JeWISH COMMITTEE (AJC) ...........................................29

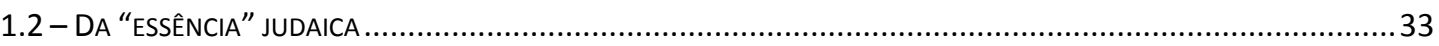

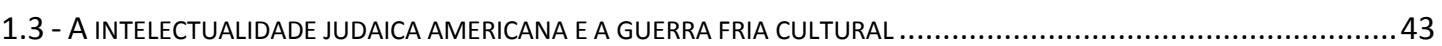

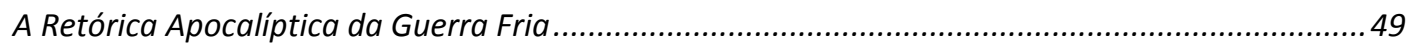

1.4 - AMERICAN JeWISH COMMITTEE E O COMBATE AO COMUNISMO...............................................................5 54

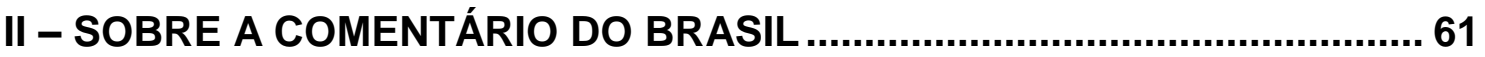

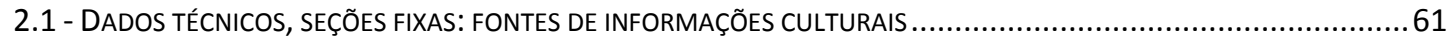

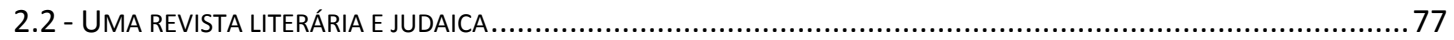

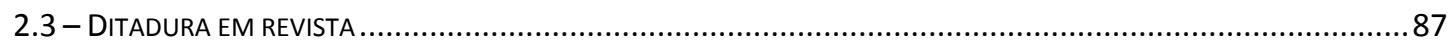

III - O MAL-ESTAR NA CULTURA EM COMENTÁRIO ............................... 99

3.1. INTEGRATION WITHOUT ASSIMILATION: LEMA E DILEMA DE SER JUDEU ......................................................99

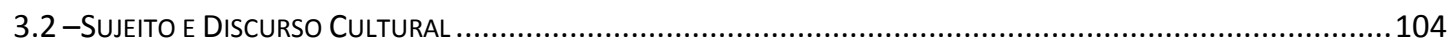

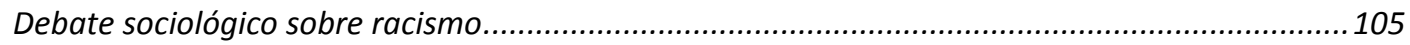

Entendimento entre judeus e cristãos.............................................................................. 112

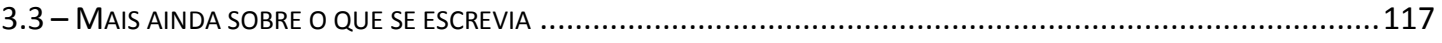

Antissemitismo, Psicologia Social e Ciência .......................................................................... 117

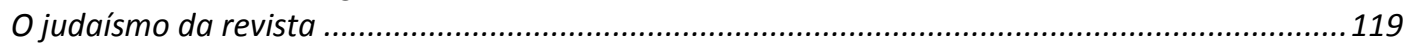

A Educação no Brasil e os inquéritos propostos pela revista ..........................................................123

Arte e Literatura: sobre o que se tratava e produções inéditas na revista ....................................125

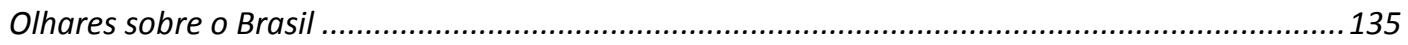

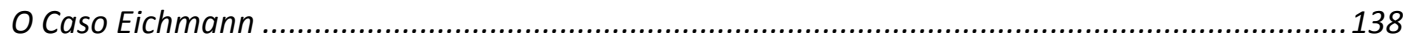

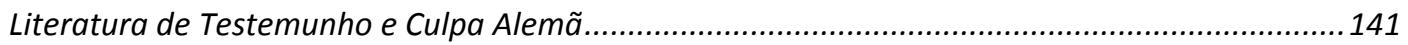

A guerra do Vietnam e A Guerra dos Seis Dias ...................................................................... 143

CONSIDERAÇÕES FINAIS .................................................................. 145

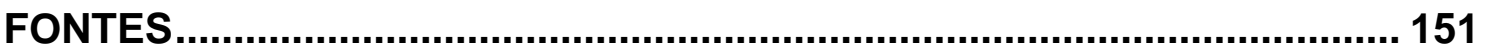

ANEXOS: TABELAS DE AUTORES....................................................... 165 


\section{INTRODUÇÃO}

O objeto desta investigação é o periódico Comentário, uma revista de opinião e informação patrocinada pelo Instituto Brasileiro Judaico de Cultura e Divulgação que circulou nos meios acadêmico e comunitário judaico na década de 1960 até 1973. Comentário foi proposta como uma publicação vinculada ao projeto editorial de uma das grandes e influentes revistas norte-americanas a Commentary, fundada em 1945 e que existe até hoje, sobre a qual tratamos no primeiro capítulo deste estudo. Na versão americana colaboraram intelectuais, especialmente judeus nova-iorquinos, que ficaram conhecidos como os "intelectuais de Nova lorque".

A Declaração de Princípios, tanto da revista americana como da sua versão brasileira, expressa uma pretensão integracionista associada a uma postura em defesa de valores liberais democráticos e de combate ao racismo, ao antissemitismo e ao totalitarismo.

Quinze anos após o surgimento de Commentary surgiu Comentário. A análise da estrutura, conteúdo e organização dos temas na revista, bem como de seus colaboradores, nos remete aos caminhos de pesquisa percorridos por uma geração de intelectuais junto às principais universidades brasileiras, sobretudo paulistas e cariocas. No seu conjunto, nos oferece um panorama (e até mesmo das matrizes) dos estudos que hoje se desdobram nas temáticas da intolerância, com foco no racismo e na discriminação. Os autores inovam nos campos da história, literatura, teatro, música e educação valorizando o sincretismo judaico-brasileiro. Atenção especial é dada ao lídiche, elemento de identidade que une a maioria dos colaboradores da revista em grande parte provenientes do Leste Europeu.

Procuramos reconstituir a trajetória de Comentário e analisar as questões suscitadas por ela no âmbito político, social e cultural brasileiro e nas suas relações com o cenário internacional. Para tanto utilizamos como fontes de pesquisa - além da própria revista - alguns documentos administrativos da revista brasileira, arquivos pessoais de membros do conselho editorial da publicação e entrevistas com alguns de seus colaboradores. Consultamos 
também o Jewish Year Book produzido no mesmo período em que a revista circulou, onde estão contidas informações sobre as comunidades judaicas estruturadas em diferentes países, incluindo o Brasil. Procuramos recuperar aspectos expressivos da vida intelectual brasileira e judaica contemporâneas, bem como a produção intelectual desse grupo na década de 1960.

$\mathrm{Na}$ sua essência, avaliamos as redes de sociabilidades e inter-relações entre a intelectualidade judaica e não-judaica nas Américas; favorecendo o inventário das principais questões que intrigavam esses intelectuais. Ao buscarmos elementos que expressassem o relacionamento da revista Comentário com a comunidade judaica novaiorquina, nos deparamos com os estudos desenvolvidos por Nathan Abrams, Nathan Glazer, Ruth R. Wisse, Fred Siegel, Terry Teachout, entre outros ${ }^{1}$.

Avaliamos em que medida a Comentário se valeu das críticas e elaborações de Commentary para criar um repertório original sustetado por importantes vozes da cultura brasileira representada por um círculo de intelectuais identificados com os objetivos da revista.

O combate às ideias totalitárias, antissemitas e racistas, um dos objetivos de Comentário, tinha como referência alguns estudos clássicos, como os trabalhos de Hannah Arendt, Cecil Roth, Leon Poliakov, Norman Cohn, entre outros. São, portanto, estes referenciais teóricos que estão sendo analisados e descortinados numa paisagem social e política de surgimento deste discurso.

A publicação é contemporânea em termos de política nacional ao breve governo de Jânio Quadros e ao de seu vice, João Goulart, que assumiu algum tempo depois da renúncia do primeiro em agosto de 1961. Cumpre lembrar que João Goulart representava para os setores militares a brecha por onde 0 comunismo poderia chegar ao poder. Tratou-se de um momento de crise durante os anos que antecederam as articulações políticas em torno da instauração do golpe militar em 31 de março de 1964 no Brasil, cujas conseqüências imediatas foram a repressão, a censura acentuadas nos chamados "anos de chumbo" da ditadura militar. Os líderes da "revolução"

\footnotetext{
${ }^{1}$ Ver: Murray Friedman (editor), Commentary in American Life, Philadelphia, Temple University Press, 2005.
} 
declararam que estas eras dirigidas em face ao avanço do comunismo, à corrupção, à administração incompetente, à inflação e alta dos preços.

Cumpre destacar que os anos que antecederam ao golpe foram caracterizados por um contexto de mobilização popular fortalecidos pelos ideólogos do governo e pelos dirigentes sindicais em torno da ideologia nacionalista e das reformas de base, de cunho sociopolítico. Foi também um período marcado por greves, incentivadas pelo governo federal para que se aceitassem as medidas propostas pelo Estado. Em São Paulo, o governador Ademar de Barros, as reprimia duramente. Registrou-se neste período intensa mobilização dos estudantes através da União Nacional do Estudantes (UNE), assim como de alguns setores da Igreja Católica que desde o início do século $\mathrm{XX}$, posicionou-se contra o comunismo.

A influência externa americana vinha se estabelecendo no Brasil desde a criação da Escola Superior de Guerra (ESG) em agosto de 1949, a partir da qual surgiram órgãos como o Instituto de Pesquisas e Estudos Sociais (IPES) e o Instituto Brasileiro de Ação Democrática (IBAD), financiado pela CIA. Inspirando as linhas do regime político instaurado em 1964, viriam garantir a ordem social e impedir a entrada do comunismo no Brasil. Esses órgãos estavam cada vez mais convictos de que apenas um movimento armado seria capaz de conter os avanços indesejáveis do comunismo².

Nesse momento de "experiência democrática" surgiu a revista Comentário, coincidindo com o período de gestação de um Estado autoritário. Houve, portanto, no decurso de sua produção, uma mudança drástica no processo social e político brasileiro, pano de fundo para a análise da sua proposta enquanto periódico de combate e protesto à intolerância e de construção de uma cultura de paz.

Assim, podemos afirmar que Comentário é produto do seu tempo: do período pós-Holocausto, delineado pela Guerra Fria e pelos conflitos que se sucederam à Partilha da Palestina em 1947, que culminou com a criação do

\footnotetext{
${ }^{2}$ Bóris Fausto, História Concisa do Brasil, São Paulo, Edusp, Imprensa Oficial do Estado, 2001, pp. 237-270.
} 
Estado de Israel em 1948 e de um Estado palestino, decisão rejeitada pelos árabes e palestinos. Criada em torno de 10 anos após estes acontecimentos, a revista é contemporânea aos conflitos armados no Oriente Médio incitados, ainda mais, pelo antissemitismo latente e a expansão de fronteiras de Israel após a Guerra dos Seis Dias, em $1967^{3}$. A revista é também contemporânea ao julgamento em Jerusalém de Adolph Eichman em 1961, fato que justifica a publicação de vários artigos sobre o tema.

Assim, consideramos como pano de fundo para a análise da revista Comentário os acontecimentos que marcaram o período de gestação do autoritarismo brasileiro concretizado na instauração da ditadura militar no Brasil. Apesar do seu perfil de combatente aos "desvios da democracia", a revista sobreviveu aos anos mais violentos em termos de censura, repressão e tortura. Além de estar atentos ao contexto nacional e internacional pósHolocausto e em plena Guerra Fria, o corpo editorial de Comentário assumiu como fato relevante para o povo judeu na Diáspora a recente realidade de um Lar Nacional como referencial identitário.

A revista nos revela em seu conteúdo o posicionamento da sua linha editorial principalmente diante dos diversos acontecimentos associados ao recém-fundado Estado Judeu e, a partir de depoimentos de alguns colaboradores, buscamos apreender as especificidades ou nuances de posicionamentos a respeito destes mesmos assuntos.

O estudo de Comentário é desenvolvido pelo viés da História da Cultura envolvendo questões da ordem da produção do saber, uma vez que seu conteúdo revela a produção de uma elite intelectual voltada para reflexões em torno da cultura em seu valor intrínseco. Dois percursos de análise se impuseram: a produção de uma revista de cultura por acadêmicos num contexto específico, assim como sua produção formulada a partir de matrizes teóricas em evidência, na década de 1960.

\footnotetext{
${ }^{3}$ Em 1967, durante a Guerra dos Seis Dias, Israel conquistou o deserto do Sinai, a faixa de Gaza (Egito), a Cisjordânia, Jerusalém Oriental (Jordânia) e as colinas do Golã (Síria), resultando na persistência do conflito no Oriente Médio e na dificuldade de criação de um Estado Palestino até os dias de hoje.
} 
As ponderações a respeito dos modos pelos quais atuamos na produção de conhecimento são essenciais para que possamos inserir esta pesquisa no universo dinâmico da historiografia da História Cultural. As reflexões de Neil Postman a respeito da linguagem nos servem de instrumento para pensarmos aquele que escreve um texto enquanto "fabricante do mundo". Assim, pressupomos que aqueles que escreviam na revista, valiam-se da ordem de "narrativa de poder, durabilidade e inspiração" e de "um relato de criação"4. Postman propõe que - sempre que escrevermos sobre algo -- estamos colocando a nossa maneira de imaginar o mundo. Se isso é perceptível através de nossos hábitos lingüísticos nos revelamos enquanto sujeitos inseridos numa determinada cultura. $\mathrm{O}$ autor, ao analisar a relação entre linguagem e realidade, enfatiza o quanto implica a construção da segunda pela primeira. Tais colocações podem ser correlacionadas com as ideias de Beatriz Sarlo que nos remetem ao tema da "guinada subjetiva através da linguagem do testemunho na história." 5

A revista Comentário está situada em meio ao debate que surge no final da década de 1960, a respeito do fim das utopias ou o surgimento de uma nova sociedade, onde o campo do conhecimento passa a ser atingido pelo impasse da indeterminação. A análise deste periódico permite a identificação deste debate teórico em seu nascedouro, permeado pela produção de seus primeiros significados, enquanto um "retorno ao passado como uma captura do presente"6.

Importante lembrar que a leitura do passado impõe uma situação delicada ao historiador que em vão busca pela "verdade histórica", pois esta é impossível de determinar. Tal postura o coloca, muitas vezes, diante de uma perspectiva que nem nega a realidade (niilista), nem afirma que uma realidade existe (metafísica). Carlo Ginzburg discute a delicada posição ${ }^{7}$ a partir de Certeau, Barthes, Vidal-Naquet, Hyden White, Croce e Serra, de modo a defender a ideia de realidade em contraposição ao relativismo, "da atitude

\footnotetext{
${ }^{4}$ Neil Postman, "Tecelões de Palavras, fabricantes de mundos", IN: O Fim da Educação, São Paulo, Graphia, 2001, p. 170.

${ }^{5}$ Beatriz Sarlo, Tempo Passado: Cultura da Memória e Guinada Subjetiva, São Paulo, Companhia das Letras, Belo Horizonte, UFMG, 2007, pp. 18-19.

${ }^{6}$ Ídem, p. 9.

${ }^{7}$ Carlo Ginzburg, Unus testis - "O extermínio dos judeus e o princípio de realidade". IN: O Fio e os Rastros, São Paulo, Cia das Letras, 2007, pp. 210-230.
} 
totalmente cética em relação às narrações históricas", infundada, segundo Ginzburg.

Questões como estas nos auxiliam a "pensar" os conteúdos da revista Comentário somados à singularidade de seus autores preocupados com os problemas do seu tempo e, em especial, da comunidade judaica em termos universais. Grande parte dos artigos nos remete ao papel preponderante que teve o Holocausto nas reflexões de intelectuais judeus e não-judeus pressupondo o mundo de projeções vivenciado pelo historiador-intérprete em relação aos significados desse passado.

"Lembrar para não esquecer", lema daqueles que lutam para que a memória do horror que foi o Holocausto seja preservada a fim de que algo de semelhante ordem jamais se repita - implica na eleição do relato, na sua colocação em primeiro plano. Beatriz Sarlo ao retomar o ensaio "O narrador: Considerações sobre a obra de Nikolai Leskov" de Walter Benjamin", considera o historiador como alguém que não reconstitui fatos do passado - uma vez que estes são mitos epistemológicos -, mas os relembra, de modo que isto implica numa condição de passado presente ${ }^{9}$ algo em relação ao qual afirma sempre haver uma dívida não paga.

É sob este ângulo que podemos (re)pensar Comentário que, desde a sua criação em 1960, se propôs uma revista "aberta" a todos os credos e pontos de vista", de opinião e informação direcionada para a essência dos "assuntos judaicos bem como temas da atualidade em geral". Ela se apresenta também como um veículo de combate ao posicionar-se frente a "luta constante da humanidade pelo respeito e diginidade do homem e pelo aperfeiçoamento de nossa civilização". Coloca-se, enfim, como elemento de integração cultural respeitando a diversidade étnica e política da sociedade brasileira como um todo. ${ }^{10}$

Comentário reúne uma geração de intelectuais e, não se pode apreender o processo de formação e produção cultural de uma geração de intelectuais, perdendo de vista o seu papel enquanto agentes sociais cuja

\footnotetext{
${ }^{8}$ Walter Benjamin, "O Narrador: Considerações sobre a obra de Nikolai Leskov", em Magia, e técnica, arte e política: Ensaios sobre Literatura e História da Cultura, São Paulo, Brasiliense, 1994.

${ }^{9}$ Beatriz Sarlo, Op. Cit., p. 28.

10 “Declaração de Propósitos", In: In: Comentário, № 2 (34), ANO IX - Vol. 9, 2 ํㅜㄴimestre, 1968.
} 
estratégia de resistência é a escrita. Os registros de suas ideias no papel impresso, assim como nas suas anotações pessoais e no conjunto de suas obras, nos oferecem os vestígios de distintos paradígmas e posturas ideológicas. Considerando o periodísmo, de uma forma geral, enquanto meio dinâmico para a circulação de ideias e instrumento formador de opinião é que nos debruçamos sobre a revista Comentário. O material permite esse "inventário" e análise a partir da desconstrução de um discurso contra a intolerância muito presente nos dias de hoje e que ali começou a ser elaborado. Importante é o trabalho de Michael Lowy que apresenta a intelectualidade judaica como uma "nova categoria social" construída a partir da trajetória do intelectual judeu de língua alemã antes da Segunda Guerra Mundial na Europa Central. Lowy explora em sua análise o conceito de afinidade eletiva para analisar o surgimento dessa categoria cuja dupla configuração espiritual se apóia na utopia romântica e no messianismo restitucionista. Pensadores oriundos dessa confluência, nascidos nos últimos vinte anos do século XIX e analisados por Lowy, fazem parte das raízes teóricas em que se funda a revista Commentary. Entre esses autores destacamos: Martin Buber (1878), Franz Kafka (1883), Gershom Scholem (1897), Walter Benjamin (1892), Ernst Bloch (1885), György Lukács(1885), Franz Rosenzweig (1886), Gustav Landauer, Ernst Toller (1893), Erich Fromm (1900) e Leo Löwenthal (1900) ${ }^{11}$.

Norberto Bobbio também nos oferece subsídios para avaliar o papel desempenhado pelos intelectuais em Os intelectuais e o poder, na perspectiva de um poder ideológico alinhado ao poder político e ao poder econômico ${ }^{12}$. $\mathrm{O}$ autor nos instiga a repensar esse perfil do intelectual idealizado, considerando seu engajamento a partir de uma causa. A obra de Sergio Miceli, por sua vez, nos serve de referência por tratar da história da formação da intelectualidade brasileira $^{13}$. Convém destacar que a revista também nos instiga a repensar a questão racial, que é "uma das vias diretoras da reflexão político - intelectual durante mais de um século" no Brasil. A produção da historiadora Ângela de

\footnotetext{
${ }^{11}$ Michael Lowy, Redenção e Utopia: o judaísmo libertário na Europa Central: um estudo de afinidade eletiva, São Paulo, Companhia das Letras, 1989.

${ }^{12}$ Norberto Bobbio, Os intelectuais e o poder: dúvidas e opções dos homens de cultura na sociedade contemporânea, São Paulo, Editora UNESP, 1997.

${ }^{13}$ Sergio Miceli, Intelectuais e Classe Dirigente no Brasil (1920-1945), São Paulo, Difel, 1979.
} 
Castro Gomes, a respeito da política cultural do Estado Novo é fundamental para nos ajudar a compreender a trajetória deste segmento da intelligentsia brasileira. $^{14}$

Para contrapor a discussão a respeito dos intelectuais e sua atuação na sociedade utilizamos também o clássico Os intelectuais e a política no Brasil: entre o povo e a nação, de Daniel Pécaut. Neste sentido, nosso trabalho se alinha aos estudos de História Social e Política direcionada para a avaliação da postura das elites intelectuais no Brasil ${ }^{15}$.

Ainda, que a revista Comentário fosse aberta a todos os credos, pensamentos e ideias, como nos revela a sua Declaração de Princípios, havia uma seleção do que seria publicado. São detalhes importantes para pensarmos o caminho percorrido pelo Conselho Editorial. Mais uma vez a "análise dos sinais" proposta por Carlo Guinzburg, a partir da noção de inconsciente freudiana, nos serve para pensarmos a respeito daquilo que não se revela através do discurso formal e preparado. Estaremos atentos aos filtros e aos silêncios que ajudaram a construir o perfil deste periódico que - como tantos outros - tinha medida para os seus comentários. ${ }^{16}$

Robert Darnton em Edição e Sedição é visto por nós como uma referência metodológica e teórica uma vez que se que dedicou a pesquisar e interpretar as matrizes ideológicas e as ações dos intelectuais envolvidos com a produção impressa que ajudou a "fazer" a Revolução Francesa ${ }^{17}$. Procuramos trazer para a nossa análise algumas de suas preocupações, como a de investigar a formação e a produção dos intelectuais identificados enquanto agentes sociais, promotores de mudanças. Sob este viés é que procuramos avaliar o envolvimento de conceituados intelectuais brasileiros, muitos dos quais ligados às principais universidades do país, com a revista Comentário. Os artigos, muitas vezes escritos no calor dos acontecimentos nacionais e

\footnotetext{
${ }^{14}$ Angela de Castro Gomes, História e Historiadores, Rio de Janeiro, Editora Fundação Getúlio Vargas, 1996, p. 191.

${ }^{15}$ Sergio Miceli, Intelectuais à brasileira, São Paulo, Cia das Letras, 2001; Daniel PÉCAUT, Os intelectuais e a Política no Brasil: entre o povo e a nação. São Paulo, Editora Ática, 1990.

${ }^{16}$ As reflexões de Carlo Guinsburg neste sentido nos servem de referência teórica e metodológica: Mitos, Emblemas e Sinais, São Paulo, Companhia das Letras, 1989.

${ }_{17}$ Robert Darnton, Edição e Sedição: O Universo da Literatura Clandestina no Século XVIII, São Paulo, Companhia das Letras, 1992; O Beijo de Lamourette, Mídia, Cultura e Revolução, São Paulo, Companhia das Letras, 1990.
} 
internacionais, muito nos revelam a respeito das influências que marcaram a forma de pensar desses "letrados".

Através do que foi publicado e citado procuramos recuperar as ideias veiculadas na revista, assim como seus principais interlocutores. Tais considerações se fazem associadas às propostas de Robert Darton e de Roger Chartier que fazem parte de uma corrente historiográfica que valoriza a história como dinâmica e complexa, múltipla de sentidos e, portanto, passível de interpretações que formulam mais questões do que afirmações, sendo enriquecida pela subjetividade de quem a produz num tempo particular pronto a se transformar. ${ }^{18}$.

São referências também os estudos desenvolvidos por Nicolau Sevcenko que se volta para o cruzamento do tema entre História, Ciência e Cultura no Brasil do final do século XIX e início do XX. Suas colocações nos servem como ponto de partida para a compreensão do lugar ocupado e papel desempenhado pela intelectualidade brasileira, principalmente nas metrópoles carioca e paulista. $^{19}$

A pertinência de tais debates e propostas metodológicas para a nossa análise sobre a revista Comentário se justifica na medida em que nosso corpus documental se baseia nos escritos de intelectuais não judeus, judeus leigos e também religiosos aqui definidos como grupos sociais formadores de opinião política, mas de alcance não popular. Alguns eram figuras proeminentes da comunidade judaica e outros dentro do Estado brasileiro caracterizando-se enquanto intelectuais cujos "nascimento, riqueza e função" se destacavam no cenário nacional. Recuperar as nuances destes velhos, novos e diversos olhares a respeito da realidade nacional requer uma proposta multidisciplinar de forma a permitir a identificação da complexa formulação das ideias e suas matrizes no ambiente acadêmico da década de 1960 no Brasil. Assim procuramos seguir a linha de análise dos sujeitos da história através dos seus discursos e ações.

\footnotetext{
${ }^{18}$ Roger Chartier, A História Cultural, entre Práticas e Representações, Rio de Janeiro/Lisboa, Editora Bertrand Brasil S. A./Difel, s/d; Roger Chartier (coord.), Práticas de Leitura, São Paulo, Estação Liberdade, 1996.

${ }^{19}$ Nicolau Sevcenko, Literatura como Missão - Tensões Sociais e Criação Cultural na Primeira República, $2^{\underline{a}}$ edição, São Paulo, Companhia Das Letras, 2003; Orfeu Extático na Metrópole São Paulo Sociedade e Cultura nos frementes anos 20, São Paulo, Companhia das Letras, 1992.
} 
Inseridas e revalorizadas em nosso aporte teórico utilizamos as reflexões da psicanálise, na produção de seu pai fundador, Sigmund Freud, que tanto influenciaram Michel Foucault, cujos trabalhos a respeito das práticas discursivas também nos servem de referência ${ }^{20}$.

As reflexões de Freud permitem a adoção de uma perspectiva de análise voltada para o discurso e para a singularidade da documentação servindo como referencial teórico por suas reflexões críticas acerca dos fenômenos e sintomas culturais e também por sua judeidade ${ }^{21}$. $O$ texto de Sigmund Freud $O$ Mal estar na cultura (1930 [1929]), proporciona uma reflexão sobre as exigências ideais de uma sociedade civilizada e leva em conta o advento da modernidade e as transformações trazidas por ela; mas, sobretudo, apresenta um aspecto principal do discurso freudiano que é o do desamparo no fundamento do sujeito.

É a partir da busca de um novo amparo que alguns desses intelectuais ligados à esquerda, assumiram uma posição de combate e resistência após a Segunda Guerra Mundial. Nem todos ficaram inertes diante dos eventos que tanto afetaram (e continuam a afetar) os judeus. A reflexão teórica a respeito do conceito freudiano de "mal-estar" se aplica, portanto, à cultura brasileira e a um certo grupo de intelectuais produtivos na década de 1960 e início de 1970. Assim, nos parece bastante pertinente analisar o caso específico dos intelectuais judeus identificados com correntes oriundas do marxismo ${ }^{22}$. Comentário reúne um número significativo de representantes destes intelectuais no Brasil, além de apontar para as novas questões que surgem enquanto preocupações das comunidades judaicas na Diáspora.

A elaboração teórica do conceito de antissemitismo moderno, que se utiliza em trabalhos centrados nesta questão até hoje, foi construída neste período por muitos dos intelectuais que escreviam no nosso objeto de análise. Importante lembrar - a respeito do papel dos intelectuais e do antissemitismo

\footnotetext{
${ }^{20}$ Tais como: Michel Foucault, $A$ Ordem do Discurso, São Paulo, Edições Loyola, 1996; As Palavras e as coisas: uma arqueologia das ciências humanas. $8^{\circ}$ ed. São Paulo: Martins Fontes, 1999.

${ }^{21}$ Aqui estaremos dialogando com as Reflexões desenvolvidas por Betty Fuks a respeito do termo que envolve o sentir-se judeu, ser judeu subjetiva e objetivamente, o modo como cada um vive o seu judaismo. Cf. Betty B. Fuks, Freud e a Judeidade: a vocação do exílio. Rio de Janeiro, Jorge Zahar Ed., 2000, p. 151, nota 3 da Introdução.

${ }^{2}$ S. Freud, "O Mal-Estar na Civilização (1930)", In: Obras Psicológicas Completas de Sigmund Freud: edição Standard Brasileira, Rio de Janeiro, Imago, 1996.
} 
na modernidade - o caso Dreyfus, cuja repercussão gerou uma divisão na intelectualidade francesa (os dreyfusard e os anti-dreyfusard) e simboliza, além do ponto de partida das manifestações e medidas baseadas no antissemitismo, o momento de total incorporação e aceitação do termo "intelectuais" 23 na Europa. O “Manifeste des intellectuales" publicado em 14 de janeiro de 1898 no jornal L'Aurore em Paris assinado por Èmile Zola, Anatole France, Proust, entre outros escritores denota o tipo de atuação e importância social do grupo cujo termo determina. Segundo Bobbio,

[...] homens não políticos, conhecidos por sua atividade prevalentemente literária, que tomam posição como homens de letras com respeito a uma prevaricação do poder político, e combatem a razão de Estado em nome da razão sem outras especificações, defendendo a verdade da qual se consideram os depositários e os defensores contra a "mentira útil". ${ }^{24}$

Hannah Arendt $^{25}$ retomou a trajetória do papel especial ocupado pelo grupo judaico dentro da organização social européia desde o Império Romano, passando pelo período medieval e atendo-se à formação dos Estados-nação e seu colapso onde identificou o crescimento dos movimentos antissemitas na Europa. A história do antissemitismo está vinculada às grandes transformações sociais e políticas européias e atualmente globais onde o grupo judaico ainda é considerado "outro", ainda conserva, ao menos no imaginário social, características particulares e vinculação com o poder. A resposta política sionista judaica ao antissemitismo colocou os judeus no centro dos acontecimentos mundiais segundo Hannah Arendt ${ }^{26}$. A partir ainda desta reflexão pensamos o posicionamento que se pretende apolítico no sentido partidário da proposta editorial de Comentário - lembrando que Hannah Arendt escreveu em Commentary - de modo a enfatizar a importância dos intelectuais judeus e da posição política que passam a ocupar no período posterior ao Holocausto, militando contra todas as formas de intolerância e colocando-se em relação à criação do Lar Nacional Judaico no meio de nações islâmicas e os conflitos gerados a partir de então.

\footnotetext{
${ }^{23}$ Norberto Bobbio, Os Intelectuais e o Poder, São Paulo, Editora UNESP, 1997, p. 123.

${ }^{24}$ Idem.

${ }^{25}$ Hannah Arendt, Origens do totalitarismo, São Paulo, Companhia das Letras, 1989.

${ }^{26}$ Idem, p. 143.
} 
Os estudos sobre o papel dos intelectuais na dinâmica do poder, a imprensa e a produção cultural no Brasil têm rendido diversos trabalhos. Muitos deles partiram de fontes produzidas por instituições acadêmicas a que alguns intelectuais estiveram relacionados ou dos meios de comunicação onde atuaram. A maioria desta produção historiográfica está centrada até as décadas de 1930 e 1940. Destacamos no Brasil os trabalhos de Sérgio Miceli (2001), Wilson Martins (1996), Carlos Guilherme Mota (1978), Marilena Chauí (1978), Maria Sylvia Carvalho Franco (1978), Angela de Castro Gomes, Lúcia Lippi de Oliveira (1983), Renato Ortiz (1994), Arãao Reis Filho (2000), Nicolau Sevcenko (2003) e Ana Luiza Martins (2001 e 2008).

Além da produção historiográfica que tem os intelectuais como objeto de estudo, destacamos os estudos sobre o antissemitismo e a história da comunidade judaica no Brasil concentrados nas décadas de 1930-1940. São de nosso interesse na medida em que a revista tinha como proposta discursiva o combate à intolerância e ao antissemitismo, em especial. Dentre os principais estudos a respeito do antissemitismo destacamos aqueles desenvolvidos por Maria Luiza Tucci Carneiro precursora de uma visão historiográfica que reavaliou a Era Vargas sob o prisma das ideologias e das ações intolerantes por parte do Estado. Em sua tese de doutorado publicada sob o título O Antisemitismo na Era Vargas: Fantasmas de uma Geração (1930-1945)",27, a historiadora trouxe à luz as circulares secretas que limitavam a entrada de judeus no país, além de indicar para a persistência do antissemitismo revitalizado durante o governo de Eurico Gaspar Dutra, portanto em plena "reabertura democrática" ${ }^{28}$ Estes dados nos colocam diante da persitência do discurso antissemita no Brasil e que vem a ser, nas décadas de 1960/1970 combatido pelo grupo da revista Comentário, muitos dos quais testemunhas oculares do Holocausto e/ou refugiados do nazismo no Brasil ${ }^{29}$.

Cabe também considerar a tradição brasileira de difusão de impressos antissemitas que, produzidos desde a década de 1930 por intelectuais conservadores católicos, integralistas e eugenistas, persistiram após a década de 1940 conforme demonstra Tucci Carneiro em seu livro O Veneno da

\footnotetext{
${ }^{27}$ Maria Luiza Tucci Carneiro, op. cit., $2^{\mathrm{a}}$ ed., 2001.

${ }^{28}$ Maria Luiza Tucci Carneiro, op. cit., 2003.

${ }^{29}$ Ver: www.arqshoah.com.br.
} 
Serpente $^{30}$. Através deste estudo, a autora retrata manifestações antissemitas no Brasil desde o século XIX até o inicio do século XXI, através da literatura, imprensa, policia politica e diplomacia ${ }^{31}$.

Além dos trabalhos de Sergio Miceli sobre o papel dos intelectuais no Brasil (2001) cumpre citar Ana Luiza Martins, e seu estudo Revistas em revista (2001). Ambos oferecem um quadro analítico da intelectualidade brasileira atuantes na Primeira República. Trata-se de um modelo, cuja metodologia seguimos, fundamentado nas biografias dos autores e relacionando-as aos seus discursos, de modo a traçar um perfil, de acordo com a temática em questão. Ainda, a partir do estudo de Martins procuramos utilizar as suas reflexões a respeito da revista enquanto periódico fragmentado e suas origens no Brasil, levando em conta dois principais aspectos: o contexto histórico que envolve o surgimento de cada revista e os dados sobre a sua produção e consumo. Para a autora os temas que pontuam o conteúdo das revistas ilutradas, no caso seu objeto de estudo, são reveladores da mentalidade de uma época e de seus interlocutores ${ }^{32}$.

Acreditamos que este trabalho sobre a revista Comentário possa representar um passo adiante no que se refere aos estudos sobre as revistas literárias ou de cultura, principalmente por se tratar de um periódico em circulação no período de repressão das ideias durante a ditadura militar. Mais intrigante ainda é o fato da revista não abordar apenas as questões da ordem

\footnotetext{
${ }^{30}$ Maria Luiza Tucci Carneiro, op. cit., 2003.

${ }^{31}$ Outras versões historiográficas sobre o antissemitismo enquanto instrumento político durante - governo Vargas podem ser identificadas nos importantes trabalhos de Marcos Chor Maio (1992), Roney Cytrynowicz (1992), Avraham Milgram (1994), Jeffrey Lesser (1995), Silvia Cortez Silva (1996), Maria das Graças Andrade Ataíde de Almeida (1997) e Fábio Koifman (2002). Entre os brasilianistas que percorreram o antissemitismo nos caminhos diplomáticos nacionais temos o trabalho de Jeffrey Lesser (1995) e entre os estudos comparativos merece destaque Leonardo Senkman (1994) que desenvolveu uma análise a respeito da política imigratória da Argentina e do Brasil em relação aos refugiados do pós-guerra. Como historiadora e pesquisadora do PROIN (Projeto Integrado Arquivo-Universidade) desde a graduação também desenvolvi estudos $(2001,2005)$ que englobaram as temáticas da diabolização do judeu, do mito da conspiração, do integralismo, do catolicismo e do nacionalismo sob o prisma da estruturação de um pensamento antissemita no Brasil. Rodrigo Patto Sá Motta (2002), ao analisar a onda de xenofobia anticomunista no Brasil nos anos de 1930, destacou a vertente antissemita em meio às representações do anticomunismo ligado à ação de estrangeiros. Todas as obras dos autores aqui relacionados encontram-se citadas na bibliografia final.

${ }^{32}$ Cf. Sergio Miceli, Intelectuais à brasileira, São Paulo, Companhia das Letras, 2001 e Ana Luiza Martins. Revistas em Revista: Imprensa e Práticas Culturais em Tempos de República. São Paulo: Editora da Universidade de São Paulo, FAPESP, Imprensa Oficial do Estado, 2001
} 
do judaísmo, mas se dedicar a pensar a cultura e a intolerância sob uma visão crítica e multidisciplinar.

Assim, a análise da Comentário nos coloca diante da dinâmica de tensões que envolviam diretamente o grupo de pensadores identificados com a linha editorial da revista. Levamos sempre em consideração que tal produção se fez em meio às articulações que culminaram no golpe militar de 1964, seguido do acirramento da repressão e da censura no final da década de 1960 e início da década de 1970 no Brasil. Este período coincide com os momentos iniciais e finais da circulação da revista que, em meio ao autoritarismo, não encontrou condições para sobreviver, segundo testemunhos dos professores Jacó Guinsburg e Bóris Schnaiderman. 


\title{
I - Da matriz norte americana
}

\section{1 -Commentary: uma iniciativa do American Jewish Committee (AJC)}

\begin{abstract}
Ao contrário de tantos escritores anteriores, que tinham apenas a sua dura estória para contar, e depois desapareciam, os "intelectuais" judeus que emergiram na década dos 40 encontraram agasalho sob as largas asas do "movimento moderno", demonstrando assim um espírito intelectual que os judeus nem sempre haviam conseguido no grande mundo. ${ }^{33}$
\end{abstract}

Commentary foi uma iniciativa do American Jewish Committee (AJC) responsável por sua criação em 1945. O AJC é a mais antiga agência de defesa judaica na América; uma organização comunitária fundada em 1906 com o objetivo de reunir os mais diversos setores da comunidade judaica americana em defesa dos direitos dos judeus radicados em vários países ${ }^{34}$. Em 1962, o AJC se apresentava como pioneiro entre as organizações americanas no combate à intolerância, protegendo os direitos civis e religiosos dos judeus no mundo e avançando na causa dos direitos humanos em todos os lugares. Contava naquele momento com unidades em mais de 60 capitais e membros em mais de 600 comunidades americanas ${ }^{35}$. Comentário, intermediada pelo Instituto Brasileiro Judaico de Cultura e Divulgação (IBCD), com sede no Rio de Janeiro, se classificava como "irmã" da norte-americana Commentary em seu primeiro número no ano de $1960^{36}$.

Elliot E. Cohen foi o primeiro editor da revista americana. Desde 1936 havia sido diretor de relações públicas da Federation of Jewish Philantropies de Nova lorque. No seu currículo ainda contavam oito anos como editor responsável do Menorah-Journal, além de artigos publicados em periódicos

\footnotetext{
${ }^{33}$ Alfredo Kazin, "O Judeu como escritor moderno", In: Comentário, Ano VIII, n. 1, 1967, p. 46.

${ }^{34}$ Cf. Nathan Abrams, "'America is Home' Commentary Magazine and the Refocusing of the Community of Memory, 1945-1960", In: Murray Friedman (editor), Commentary in American Life, Philadelphia, Temple University Press, 2005, p. 10.

${ }^{35} \mathrm{Cf}$. Cabeçalho contendo informação institucional em "Press Release on the opening of the Israel Office", (14/02/1962), In: www.ajcarchives.org/ajarchive/Digitalrchive.aspx, acesso em 9/06/2010.

${ }^{36}$ Ver In: Comentário no 1 , ANO I, 1ํo trimestre, 1960, p. 4.
} 
como Nation, New York Times Magazine entre outros. Foi classificado pelo Committee Reporter, periódico anterior do AJC, como um escritor e estudioso voltado para as questões judaicas e problemas sociais. No mesmo periódico, destacou-se enquanto um elemento curricular importante, a relação entre Cohen descobrir escritores judeus americanos e o fato destes se tornarem então conhecidos na cena literária:

[...] a close and discerning student of Jewish questions and social problems for many years and himself a writer of distinction [...]. [...] and this capacity was credited with the discovery of many talented young American Jewish writers who have since become well-known in the literary scene. ${ }^{37}$

De acordo com o sociólogo Nathan Glazer, um dos jovens editores de Commentary, os rumores que se ouvia do passado de Cohen como alguém que fez parte de um grupo de intelectuais próximo ao Partido Comunista foram sendo apagados e o que se ressaltava era o seu passado como responsável pelas relações públicas da Federation of Jewish Philanthropies ${ }^{38}$.

Para Glazer, o grupo de intelectuais reunidos em torno da revista que antecedeu Commentary, a Contemporary Jewish Record (CJR), não combinava muito com o perfil do AJC: “... the most conservative of the major Jewish defense organizations, ...,39. A exemplo disso citou Max Horkheimer, um dos expoentes da Escola de Frankfurt, que no ínício da década de 1940 estaria trabalhando para o AJC em estudos sociológicos sobre antissemitismo (incluindo a psicanálise e outras categorias de pensamento pós-marxistas). Essas categorias tão em voga na época, segundo o historiador Murray Friedman ${ }^{40}$, encaravam a religião e a identidade grupal como formas arcaicas e

\footnotetext{
37 “[...] um estudante de discernimento e próximo das questões judaicas e dos problemas sociais por muitos anos e ele mesmo um escritor de destaque [...]. [...] e essa capacidade foi creditada com a descoberta de muitos jovens escritores americanos judeus talentosos, que desde então se tornaram conhecidos na cena literária." Cf. o artigo "Elliot E. Cohen New Editor of AJC Record; Plan New Monthly Review for Fall of 1945", The Committee Reporter (maio de 1945). www.ajcarchives.org/ajarchive/Digitalrchive.aspx, acesso em 10/02/2010.

${ }^{38}$ Nathan Glazer, "Commentary: The Early years", In: Murray Friedman (editor), Op. Cit., 2005, p. 41.

${ }^{39}$ Idem, p. 39.

${ }^{40}$ Murray Friedman dirigiu até 2004 Myer and Rosaline Feinstein Center for American Jewish History -Temple University.
} 
primitivas superáveis na medida em que as pessoas se tornariam mais cultas e ilustradas ${ }^{41}$ Associados diretamente à revista, Glazer citou Clement Greenberg, que nada sabia de questões judaicas, havia sido editor da Partisan Review ${ }^{42}$ e escrevia crítica de arte para o periódico Nation. Autores que contribuíam na revista do $A J C$ também haviam sido colaboradores na esquerdista Partisan Review tais como: Harold Rosemberg, Lionel Trilling, Isaac Rosenfeld, Sidney Hook, Hannah Arendt e outros.

Foi, portanto um grupo de intelectuais historicamente identificados com correntes de pensamento de esquerda que fez Commentary, cujo primeiro número saiu em novembro de 1945, e foi anunciado em outubro de 1945 pelo The Committee Reporter. Com destaque, anunciavam uma lista de nomes de escritores judeus americanos, religiosos e acadêmicos. Entre eles, estavam: Percy S. Corbett, professor de Direito Internacional da Universidade de Yale, cujo artigo propunha um movimento para o desenvolvimento de um mecanismo internacional eficaz no sentido de assegurar os direitos humanos e proteger as minorias; Salo Baron, historiador da Universidade de Columbia, discutindo a reconstrução espiritual da judiaria européia; James Rorty, jornalista que escrevera a primeira reportagem a respeito dos estudos sobre antissemitismo financiados pelo $A J C$ e desenvolvidos pelo Institute of Social Research da Universidade de Columbia, dirigido por Max Horkheimer e Leo Lowenthal que haviam pertencido à Escola de Frankfurt. ${ }^{43}$

O primeiro número de Commentary foi impresso pela Yale University Press prevendo-se que custaria $\$ .40$ (quarenta centavos de dólar). ${ }^{44}$ Segundo Nathan Glazer este número da revista trazia uma mistura estranha de escritores da Partisan Review, judeus alemães emigrados, professores da Ivy League $^{45}$ e um grupo variado de escritores freelance de esquerda. Glazer que

\footnotetext{
${ }^{41}$ Cf. Murray Friedman, "Introduction. Comentary: The First Years", In: Murray Friedman (editor), Op. Cit., 2005, p. 2.

42 Partisan Review foi fundada em 1934 como uma alternativa à revista New Masses, publicação do American Communist Party.

43 "First Issue of $A J C^{\prime}$ 's New Monthly Commentary, to Appear Shortly". The Committee Reporter (outubro de 1945). www.ajcarchives.org/ajarchive/DigitalArchive.aspx, acesso em 10/02/2010. 44 ídem.

${ }^{45}$ A Ivy League era composta por oito universidades: Brown, Columbia, Cornell, Dartmouth College, Harvard, Pennsylvania, Princeton e Yale. Seus integrantes representavam uma elite histórica cristã e privilegiada norte-americana que exercia influência em conselhos diretivos, instituições acadêmicas, nos grandes jornais e meios de comunicação, nos escritórios de advocacia e no governo da América. Foi essa elite histórica que preencheu as fileiras da CIA
} 
fez parte da equipe editorial da revista desde o início (e havia trabalhado por um ano na revista bimestral do $A J C$ que antecedeu Commentary, a já citada Contemporary Jewish Record - CJR) afirmou que o corpo editorial de Commentary refletia "a divorce between Jewish writers and intellectuals and Jewish life - Jewish issues - that would be unimaginable today." ${ }^{46}$

Divorciados que estavam da vida organizada judaica, os intelectuais que contribuíram para as páginas de Commentary nos seus primeiros anos representaram um modo singular e eficaz de introduzir uma conexão entre a vida judaica em todos os seus aspectos e a cultura americana de um modo geral ${ }^{47}$. Cohen, nos primeiros anos do pós-guerra, mobilizou-se no sentido de desenvolver uma orgulhosa comunidade judaica americana que abraçara a modernidade e que encontrava espaço nessa mesma modernidade para manter um espírito judaico distinto e uma identidade cultural ${ }^{48}$. Esse esforço transparece em sua resposta ao então jovem Norman Podhoretz (aquele que iria mais tarde ocupar o seu lugar) no que tange à diferença entre as revistas Partisan Review e Commentary. Para Cohen, a segunda "era conscientemente uma revista judaica e apesar de Partisan Review ser judaica em função de sua liderança e colaboradores, ela não sabia disso." ${ }^{49}$

Tal definição se coloca diante do processo de significação dessa conscientização cuja origem atribuímos ao grupo de intelectuais judeus alemães, contemporâneos no tempo e espaço aos acontecimentos que antecederam a Segunda Guerra Mundial. Parte deles, vinculados a Escola de Frankfurt, irá desenvolver estudos sobre o antissemitismo, como pesquisadores-diretores nos Estados Unidos depois da Segunda Guerra, financiados pelo AJC.

nos seus primeiros tempos acreditando na democracia, mas temendo ao mesmo tempo o igualitarismo irrefreado. Cf. N. da T. In: SAUNDERS, Frances Stonor. Quem pagou a conta? Rio de Janeiro, Record, 2008, p. 14 e pp. 51, 57.

46 "um divórcio entre os escritores e intelectuais judeus da vida judaica - as questões judaicas que seria inimaginável hoje.Nathan Glazer, "Commentary: The Early years", In: Murray Friedman (editor), Op. Cit., 2005, p. 49.

${ }^{47}$ Nathan Glazer, "Commentary: The Early years", In: Murray Friedman (editor), Op. Cit., 2005, p. 50.

${ }^{48}$ Cf. Murray Friedman, "Introduction. Commentary: The First Years", In: FRIEDMAN, Murray (editor), Op. Cit., 2005, p. 2.

49 Ídem, ibidem. 
1.2 - Da "essência" judaica

\begin{abstract}
Nenhum leitor [da versão hebraica] deste livro achará fácil colocar-se na posição emocional de um autor que é ignorante da linguagem da sagrada escritura, completamente alheio à religião de seus pais - bem como a qualquer outra religião - e não pode partilhar de ideais nacionalistas, mas que, no entanto, nunca repudiou seu povo, que sente ser, em sua natureza essencial, um judeu e não tem nenhum desejo de alterar essa natureza Se the fosse formulada a pergunta: 'Desde que abandonou todas essas características comuns a seus compatriotas, o que resta em você de judeu?', responderia: 'Uma parte muito grande e, provavelmente a própria essência'. Não poderia expressar claramente essa essência em palavras, mas algum dia, sem dúvida, ela se tornará acessível ao espírito científico.

Assim, constitui experiência de um tipo muito especial para esse autor um livro seu ser traduzido para a língua hebraica e colocado nas mãos de leitores para quem esse idioma histórico é uma língua viva; um livro, além disso, que trata da origem da religião e da moralidade, embora não adote um ponto de vista judaico e não faça exceções em favor do povo judeu. O autor espera, contudo, estar de acordo com seus leitores na convicção de que a ciência sem preconceitos não pode permanecer estranha ao espírito do novo judaísmo. VIENA, dezembro de $1930 .^{50}$
\end{abstract}

Este prefácio de Freud à tradução hebraica da obra Totem e Tabu ao mesmo tempo em que apresenta um declarado conteúdo afetivo de pertencimento a uma cultura, adverte para a existência de um "novo judaísmo". Freud - assim como muitos outros intelectuais judeus na Europa tidos como "assimilados" - não praticava a religião. Ele a via como uma ilusão coletiva ${ }^{51} \mathrm{e}$ tampouco partilhava ideais nacionalistas ou que "assumissem um ponto de vista propriamente judaico". Essa herança, que ele definiu como sendo a sua própria essência se projeta na Psicanálise por meio da qual ele exerceu a sua judeidade ${ }^{52}$. Judeidade esta, como algo a se construir, subjetivo em contraposição à ideia de um Judaísmo ${ }^{53}$ canônico, repetitivo, inalterável, essencialista ${ }^{54}$.

50 Sigmund Freud, Prefácio à tradução hebraica de "Totem e Tabu (1913)", In: Obras Psicológicas Completas de Sigmund Freud: Edição Standard Brasileira, Rio de Janeiro, Imago, 1996, p. 19.

${ }^{51}$ Cf. Sigmund Freud, "O Futuro de uma Ilusão (1927)", In: Obras Psicológicas Completas de Sigmund Freud: Edição Standard Brasileira, Rio de Janeiro, Imago, 1996.

${ }^{52}$ A respeito do conceito de Judeidade, ver o trabalho de Betty Bernardo Fuks, Freud e a Judeidade: A Vocação do Exílio. Rio de Janeiro, Jorge Zahar Ed., 2000.

${ }^{53}$ Relativo ao conjunto da religião e ética do povo judeu.

${ }^{54}$ Betty B. Fuks em fala de 9/04/2010 afirmou que Freud abandonou o conceito filosófico de identidade que é o que confere a algo ou a alguém sua natureza ou sua essência, substituindo- 
Entendemos estar relacionada a assunção de uma herança arcaica judaica nesta afirmação de Freud à produção intelectual dos judeus de esquerda que representaram as matrizes teóricas da revista Commentary, próprios sujeitos da diáspora que ao mesmo tempo em que estão fora, estão dentro, pertencem e não pertecem a uma nação. É a partir dessa condição que se encontram semelhanças decorrentes do desenvolvimento intelectual de homens de um mesmo tempo cuja afinidade eletiva, conforme se verá adiante, se fez presente. Pensadores cujo traço judaico se manifestou em suas obras do mesmo modo que suas convicções universalistas de esquerda, o que se converteu num dilema para muitos.

A própria Psicanálise foi convocada em estudos desenvolvidos pela Escola de Frankfurt, onde atuaram alguns destes intelectuais. Estamos pensando, sobretudo naqueles que contribuíram para se pensar 0 comportamento individual e social. Para Martin Jay, “(...) a crescente integração da psicanálise à teoria crítica coincidiu com a maior atenção que começaram a dedicar ao antissemitismo durante a guerra" ${ }^{2}$. Essa "matriz" teórica se manifestará mais adiante na revista Commentary através da produção de muitos de seus colaboradores enquanto substituta do marxismo. Norman Podhoretz, editor-chefe entre 1960-1995, afirmou que Freud havia suplantado Marx como a principal influência formativa no pensamento da "Família" (referindo-se aos chamados New York intellectuals) nos anos que se seguiram à Segunda Guerra Mundial ${ }^{56}$.

Já mencionamos aqui a afirmação de Elliot Cohen (primeiro editor de Commentary) a respeito dos colaboradores judeus da Partisan Review que não sabiam a respeito de seu judaísmo. Nathan Abrahams menciona a mesma frase de Cohen citada por Norman Podhoretz: "The main difference between Partisan Review and Commentary is that we admit to being a Jewish magazine

o pelo conceito de identificação (inconsciente), crucial à concepção psicanalítica da subjetividade e análise dos laços sociais. A identificação, segundo a psicanalista, pressupõe um eu cujo núcleo é cindido, afeito a incorporações sucessivas. Betty B. Fuks, Mesa-redonda: "Psicanálise, Judeidade e Cultura", 9/04/2010.

${ }^{55}$ Cf. Martin Jay, "Os Judeus e a Escola de Frankfurt: Teoria Crítica e sua Análise do Antisemitismo", In: VIEIRA, Nelson H. (org.). Construindo a Imagem do Judeu: Algumas Abordagens Teóricas, Rio de Janeiro, Imago, 1994, p. 100.

56 "A principal diferença entre Partisan Review and Commentary é que nós admitimos ser uma revista judaica e eles não." In: Norman Podhoretz, Ex-Friends. Falling out with Allen Guinsberg, Lionel and Diana Trilling, Lillian Hellman, Hanna Arendt, and Norman Mailer, California:

Encounter Books, 2000, p. 142. 
and they don't $t^{57}$. Aparece aqui a preocupação e um orgulho manifesto em afirmar o judaísmo enunciado por Podhoretz.

Partisan Review não era uma revista com laços institucionais judaicos formais como Commentary que, ao contrário das revistas judaicas da época, possuía liberdade editorial completa ${ }^{58}$, ocorrência rara na vida organizacional judaica $^{59}$. De acordo com Ruth R. Wisse que analisou o "judaísmo de Commentary", a revista inaugurou uma nova era que se diferenciava da anterior na medida em que antes os escritores e leitores judeus poderiam escolher em apenas duas vertentes: revistas, tais como The Menorah Journal e Jewish Frontier, que lidavam quase que exclusivamente com assuntos tipicamente judaicos e revistas como Partisan Review ou The New Republic, onde colaboradores judeus escreviam sobre assuntos gerais. Commentary procurou ser o espaço de encontro dessa antiga bifurcação cultural a que os judeus modernos estiveram acostumados: "na sua casa", dentro da comunidade ou "na rua", interagindo com o mundo ao seu redor. ${ }^{60}$ Seria, portanto um lugar de integração cultural e, portanto, com potencial difusor de ideias expandido.

Quem eram esses intelectuais "de esquerda" que não participavam da vida organizada judaica, mas escreviam numa revista de cultura e opinião institucional judaica? Tal contradição implica dois caminhos que se opõem: o etnocentrismo cultural da religião judaica e o universalismo militante das utopias revolucionárias, como a socialista, por exemplo. Michael Lowy nos oferece um caminho de historicização a respeito da origem intelectual de alguns deles.

\footnotetext{
${ }^{57}$ Nathan Abrams, "'America is Home' Commentary Magazine and the Refocusing of the Community of Memory, 1945-1960", In: Murray Friedman (editor), Op. Cit., 2005, p. 19, apud Terry A. Cooney, "New York Intellectuals and the Question of Jewish Identity", American Jewish History 80, 1991, p. 345 conforme Norman Podhoretz, Making it, New York, Random House, 1967, pp. 99-100.

${ }^{58}$ Segundo Nathan Abrams esse conceito de liberdade editorial serviu para afastar a imagem da revista de uma publicação institucional. Ela foi vista como única sobre esse aspecto. Abrams, no entanto, apresenta uma série de depoimentos e documentos que demonstram haver uma relação estreita entre a revista e o $A J C$, dela funcionando como um instrumento extremamente importante para o $A J C$ na propagação da filosofia da instituição. Cf. Nathan Abrams, "'America is Home' Commentary Magazine and the Refocusing of the Community of Memory, 1945-1960", In: FRIEDMAN, Murray (editor), Op. Cit., 2005, pp. 10-28.

${ }^{59}$ Cf. Murray Friedman, "Introduction. Commentary: The First Years", In: FRIEDMAN, Murray (editor), Op. Cit., 2005, p. 2.

${ }^{60}$ Ruth R. Wisse. "The Jewishness of Commentary", In: FRIEDMAN, Murray (editor), Op. Cit., 2005, p. 54.
} 
Michael Lowy em sua tese Redenção e Utopia: o judaísmo libertário na Europa Central: um estudo de afinidade eletiva se utiliza do conceito de afinidade eletiva desenvolvido por Max Weber para analisar o surgimento da chamada intelectualidade judaica na Europa Central enquanto uma categoria social nova e identificar a época histórica - primeira metade do século $X X$ - em que aparece a confluência de um romantismo utópico-libertário e de um messianismo restitucionista. $O$ autor procurou reconstituir esse "universo cultural socialmente condicionado" tendo como referência a obra de quinze autores cujo pensamento teria uma dimensão fundamental comum ${ }^{61}$. Alguns pensadores oriundos dessa confluência, nascidos nos últimos vinte anos do século XIX e analisados por Lowy, têm em comum as raízes teóricas em que se funda a revista Commentary. Entre esses autores destacamos: Martin Buber (1878-1965), Franz Kafka (1883-1924), Gershom Scholem (1897-1982) ${ }^{62}$, Walter Benjamin (1892-1940), Ernst Bloch (1885-1977), György Lukács(18851971), Franz Rosenzweig (1886-1929), Gustav Landauer (1882-1919), Ernst Toller (1893-1939), Erich Fromm (1900-1980), que fora aluno de Scholem, e Leo Löwenthal (1900-1993).

Em sua análise sociológica Lowy identificou um processo de escolarização em massa da juventude judaica burguesa que levou à formação dessa intelectualidade judaica na Europa Central enquanto um caminho para se conquistar respeitabilidade na Alemanha impregnada de sentimento nacionalista. Sabe-se que os judeus não eram considerados alemães, eram párias.

A corrente dominante na cultura da Mitteleuropa na virada do século era o romantismo anticapitalista, momento em que os filhos dos empresários, comerciantes e banqueiros judeus romperam com o modo de vida burguês de seus pais e buscaram um caminho intelectual para viver, entre as artes e as letras, a Kultur que engloba ainda uma simpatia pela espiritualidade e pela religião. Lowy destaca um "retorno ao passado que estava no núcleo da atitude romântica", um retorno às suas raízes históricas, religiosas, à sua própria cultura, à sua ancestralidade. Um movimento de dessecularização ocorreu

\footnotetext{
${ }^{61}$ Michael Lowy, Redenção e Utopia: o Judaísmo Libertário na Europa Central - Um Estudo de Afinidade Eletiva, São Paulo, Companhia das Letras, 1989, p. 27.

${ }^{62}$ Gershom Scholem publicou em In: Comentário o artigo "Autoridade Religiosa e Misticismo", In: Comentário, Ano VI, n. 1, 1965, pp. 42-54.
} 
nesta geração em contraposição à anterior de assimilação cultural. Aliados a isso, de maneira dinâmica, se colocaram os movimentos de contestação à ordem estabelecida que atraiam esses intelectuais por diversos motivos: a marginalidade a que eram submetidos, a luta pelo fim das desigualdades sociais e nacionais, a recusa dos nacionalismos, etc. ${ }^{63}$ Contradições políticas e culturais dessa intelectualidade judaica específica da Europa Central que podem ser representadas por suas obras e, em especial, a de Walter Benjamim $^{64}$.

Sábio e místico, renovador da espiritualidade judaica e autor mais representativo do socialismo religioso na cultura judaico-alemã foi Martin Buber grande difusor do existencialismo judaico. Tendo dedicado a sua erudição ao pensamento hassídico, buscou por uma resposta às desumanas condições da existência, que se contrapunha ao intelectualismo medieval judaico. Daí a valorização do canto, da natureza, o estímulo à dança no programa hassídico. Essa retomada se deu no século $\mathrm{XX}$, quando o nazismo forneceu os motivos para se suspeitar do "desalmado intelectualismo".

Outro importante colaborador da revista Commentary era Abraham Joshua Heschel, considerado pelo sociólogo Joseph H. Lockstein como "o mais substancioso intérprete do hassidismo"65. Para Lockstein "o neo-hassidismo seria tanto uma resposta às indagações do judeu do século XX.como o fora 0 hassidismo para o século XVIII". Seu artigo "A crise da religião em nosso tempo" foi traduzido e publicado em Comentário em $1960^{66}$. Outros artigos expressivos dos sistemas filosóficos de pensadores religiosos como Buber e Heschel foram reproduzidos da revista americana Commentary e publicados em Comentário, entre os quais "Três Pensadores Judeus Contemporâneos Kaplan - Heschel - Buber", de Maurice Friedman, professor de filosofia religiosa, cujo texto inclui ainda o pensador Mordecai Kaplan, considerado tal como Buber e Heschel um pensador típico de uma das tendências dominantes do judaísmo liberal norte-americano no início da década de $1960^{67}$. Temos

\footnotetext{
63 ídem, pp. 37-41.

64 ídem, a esse respeito ver capítulo 7.

${ }^{65}$ Sobre Lockstein, Heschel e seus artigos publicados em Comentário ver Tabela 1 (b).

${ }^{66}$ Cf. Joseph H. Lockstein, "O Existencialismo Judaico”, In: Comentário, abr-mai-jun, ano II, n.

2, 1961, pp. 166-172.

67 Sempre cf. mais referências biográficas e dos artigos citados em "Tabela de autores" ("internacionais", neste caso) no final deste trabalho. As tabelas não contemplam todos os
} 
também o artigo do ensaísta John Sherman, "Martin Buber: o não conformista Judeu", que apresenta o pensador enquanto um espírito livre e corajoso, sionista e nacionalista, não conformado com o judaísmo ortodoxo e que defendia um abrandamento da política israelense em relação ao problema árabe ${ }^{68}$.

Michael Lowy, estudioso do judaísmo libertário na Europa Central, mencionou a Escola de Frankfurt como um exemplo que congregou elementos cujo cruzamento cultural (principalmente no que se refere aos "aspectos messiânicos e/ou libertários") merece ser destacado a despeito de seu racionalismo e da (autocrítica da) Aufklärung (Esclarecimento), "tendência dominante de seu pensamento". Nomeou como representantes dessa forma de pensar Leo Löwenthal, Walter Benjamin, Eric Fromm e também Kracauer, Hokheimer e Adorno ${ }^{69}$.

O lançamento por parte do $A J C$ dos principais estudos a respeito do antissemitismo nos Estados Unidos nos primeiros anos do pós-guerra dividiu com outras organizações de defesa judaicas a preocupação em compreender o fascismo e o antissemitismo. Projetou-se como uma das vias de entrada de uma postura cuja "perspectiva aberta" e "dimensão crítica" (em relação à Escola de Frankfurt - de pensamento marxista - a que estava vinculada ${ }^{70}$ ) se aliavam ao fato de estar marcada por uma "categoria social intelectual judaica". A responsabilidade por tais estudos pesou sob Max Horkheimer - que havia sido diretor em 1930 do Instituto de Pesquisa Social de Frankfurt - "e seus colegas"71.

Os estudos teóricos produzidos por estes pensadores se dividem em antes e depois das experiências transnacionais enquanto emigrados judeus da

autores e artigos da revista, mas são resultado de uma seleção daqueles citados durante o texto deste trabalho. Apenas os primeiros anos da revista tiveram todos os seus artigos e autores pesquisados.

${ }^{68}$ John Sherman, "Martin Buber: o não-conformista judeu", In: Comentário, Ano VI, n. 2, 1965, pp. $132-135$.

${ }^{69}$ Michael Lowy, op. cit., 1989, p. 150.

${ }^{70}$ Sobre o Instituto de Pesquisa Social de Frankfurt ver A. Schimidt e G. E Rusconi, La Scuola di Francoforte, De Donato editore, Bari, 1972; Phil Slater, Origem e Significado da Escola de Frankfurt, Zahar Editores, Rio de Janeiro, 1978; Martin Jay, La Imaginacion dialética - Uma historia de La Escuela de Frankfurt, Madri: Taurus, 1974; Olgária Matos, Os Arcanos do Inteiramente Outro - Escola de Frankfurt - Melancolia e Revolução, São Paulo, Brasiliense, 1996; Rolf Wiggershaus, Escola de Frankfurt - história, desenvolvimento teórico, significação política, tradução: Vera de Azambuja Harvey, Rio de Janeiro, Difel, 2002.

${ }^{71}$ Nathan Glazer, "Commentary: The Early years", In: Murray Friedman (editor), Op. Cit., 2005, p. 43. 
Alemanha nazista. Seus trabalhos na Alemanha pré-nazi, sobretudo os de Max Horkheimer, tendiam a colocar a chamada "questão judaica" sob o prisma do conflito de classes tão somente, praticamente ignorando o antissemitismo enquanto um problema em si, preocupado que estava em teorizar o socialismo. Nos Estados Unidos, no entanto, e aqui se deve incluir Adorno e Lowenthal, a "questão judaica" e suas implicações sociopolíticas ganharam espaço em suas pesquisas a partir do desenvolvimento da temática totalitária, fascista e socialista.

A imagem do judeu foi formulada como sendo este o representante do "não-idêntico", alvo da raiva que caracteriza o impulso dominador totalitário da civilização ocidental, equivalente metafórico de um resíduo de sociedade que preserva a negação. Mas essa mudança não se deu de imediato, quando Horkheimer imigrou em 1934. Ainda em 1939, em seu ensaio "Die Juden und Europa" (Os Judeus e a Europa), o antissemitismo se subordinava à crise do capitalismo. Durante a guerra, no entanto, tal abordagem começou a mudar. Os teóricos de Frankfurt fizeram planos de um projeto voltado ao antissemitismo que foi publicado em 1941, intitulado The Studies in Philosophy and Social Science. Em 1943, o Jewish Labor Committee patrocinou uma importante pesquisa a respeito da atitude dos trabalhadores americanos para com os judeus ${ }^{72}$.

O jornalista James Rorty ${ }^{73}$, um dos intelectuais de Nova lorque ${ }^{74}$, escreveu em Commentary a primeira reportagem a respeito desses estudos sobre antissemitismo financiados pelo AJC e desenvolvidos pelo Institute of Social Research da Universidade de Columbia (dirigido pelo grupo da Escola de Frankfurt - Max Horkheimer e Leo Lowenthal). A reportagem "American Fuehrer in Dress Rehearsal" foi publicada no primeiro número da revista

\footnotetext{
${ }^{72}$ Cf. Martin Jay, "Os Judeus e a Escola de Frankfurt: teoria crítica e sua análise do antisemitismo", In: VIEIRA, Nelson H. (org.). Op. Cit., 1994, pp. 91-101.

${ }^{73}$ Quando o artigo foi publicado em novembro de 1945 sob o título de American Fuehrer in Dress Rehearsal, James Rorty, seu autor, foi descrito como um jornalista voltado para a luta pelos direitos civis e que escrevia a respeito das relações raciais: "One of the last of the crusading journalists, James Rorty has been fighting all his career to extend civil rights and to expose the dangers threatening them. (...). Mr. Rorty, who has been working and writing specifically in the field of race relations for some years, (...)." Cf. http://www.commentarymagazine.com/viewarticle.cfm/american-fuehrer-in-dress-rehearsal-3, acesso em 11/01/2011.

${ }^{74}$ Rorty não está na lista de Daniel Bell, mas fazia parte do grupo segundo Neil Gross, Richard Rorty: The Making of an American Philosopher, Chicago, University of Chicago Press, 2008, p.16.
} 
americana em 1945, e o título original de acordo com o The Committee Reporter era "American Fueher in Preview"

Max Horkheimer foi quem dirigiu o Institute of Social Research da Universidade de Columbia. Pode-se afirmar que era representante do grupo de intelectuais judeus alemães cujo número de imigrantes não era dos maiores aproximadamente 140.000 - mas que teve grande impacto sobre a cultura norte-americana ${ }^{76}$. Assim que imigraram esses intelectuais passaram a influenciar o pensamento americano nas ciências, nas artes, nas Universidades e no discurso intelectual de um modo geral. Rapidamente ocuparam posições de destaque desenvolvendo atividades profissionais enquanto escritores, professores, fotógrafos de moda e de notícias, psicanalistas, diretores de cinema, maestros de orquestras e, eventualmente, presidentes de associações acadêmicas. Notavelmente eles adentraram em muitos campos da cultura responsabilizando-se por produtos culturais que se destacaram como expressões representativas da América. A herança judaica alemã havia encontrado um lar nos Estados Unidos da América, através de nomes como os de Horkheimer, Friedrich Pollock, Theodor W. Adorno, Herbert Marcuse, Leo Lowenthal, Erich Fromm, Henryk Grossman, Franz Neumann e Otto Kirschheimer ${ }^{77}$.

Segundo Joseph B. Maier, esses judeus alemães - a despeito das diferenças que havia entre eles - liberais, ortodoxos, sionistas ou não compartilhavam um ethos essencialmente comum, uma forte sensação de destino partilhado e uma recusa firme de voltar para o gueto ou trair a fé de seus pais. Um espírito que continuaram a partilhar pois viam um futuro na América e em Israel. Tornaram-se aculturados, porém não assimilados na América ou em Israel ${ }^{78}$.

Para Maier, entre os muitos projetos acadêmicos que o $A J C$ patrocinou visando o interesse dos judeus americanos de grande impacto, talvez o mais forte de todos, foram as séries Estudos sobre Preconceito (Studies on

\footnotetext{
75 "First Issue of AJC's New Monthly Commentary, to Appear Shortly". The Committee Reporter (outubro de 1945). www.ajcarchives.org/ajarchive/DigitalArchive.aspx, acesso em 10/02/2010. ${ }^{76}$ Joseph B. Maier, "A Precious Legacy", In: The German-Jewish Legacy in America 1938-1988 - A Symposium, American Jewish Archives Journal, Volume XL, November, 1988, number 2, p. 283. http://americanjewisharchives.org/journal/PDF/1988 $4002 \quad 00 . p d f$, acesso em $4 / 01 / 2011$.

77 Ídem, pp 283-284.

78 Ídem, p. 285.
} 
Prejudice Series) divididas em cinco partes e dirigidas por Horkheimer, Consultor-chefe de Investigação Científica do AJC entre os anos de 1944$1947^{79}$. O volume intitulado The Authoritarian Personality (A Personalidade Autoritária) foi escrito por Theodor Wiesengrund-Adorno em colaboração com outros pesquisadores-membros do Berkeley Public Opinion Study Gorup: Ilse Frenkel-Brunswik, Daniel J. Levinson e R. Nevitt Sanford. Hoje, um clássico, The Authoritarian Personality foi publicado em 1950, ano que Adorno regressou à Europa e reorganizou o Instituto de Pesquisa Social de Frankfurt. Este evento que marcou a ciência social americana ao produzir um modelo de sociologia empírica, gerou pesquisas posteriores sobre as causas psicológicas e políticas do antissemitismo e do fascismo ${ }^{80}$.

Entre as cinco publicações dos membros do Instituto Social de Pesquisa de Frankfurt que participaram da série Estudos sobre Preconceito, citamos o trabalho de Leo Lowenthal que, em parceria com Norbert Guterman, escreveu The Prophets of Deceit. Paul Massing desenvolveu o volume Rehearsal of Destruction, sobre os movimentos antissemitas alemães anteriores à Primeira Guerra gerados, sobretudo em virtude da depressão econômica de 1873$1896^{81}$.

Ao redor de projetos culturais financiados pelo $A J C$, como o dos estudos sobre 0 antissemitismo, outros intelectuais foram sendo convocados a colaborar. Nas páginas da revista Commentary discutia-se antissemitismo e o racismo aproximando-os na luta pelos Direitos Civis. Conforme Natham Abrams, o AJC havia há muito aprendido que o modo mais eficaz de se combater o antissemitismo não era defender tão somente os direitos dos judeus, mas a igualdade de todos os americanos, incluindo os judeus ${ }^{82}$.

A discussão étnica, de gênero e de sexualidade foi se firmando cada vez mais nos Estados Unidos se espalhando pelo Ocidente. Em relação à questão antissemita, em março de 1960, de acordo com Ralph Friedman, presidente do Comitê de Relações Exteriores do $A J C$, traçaram-se planos na América Latina

\footnotetext{
${ }^{79}$ Cf. Mass Media/ Education Committee Minutes File, 8/03/1960, AJC Subject Files Collection. 1960 (9), p. 2, www.ajcarchives.org/ajarchive/DigitalArchive.aspx, acesso em 13/01/2011. ${ }^{80}$ Ídem, p. 284.

${ }^{81}$ Cf. Martin Jay, "Os Judeus e a Escola de Frankfurt: teoria crítica e sua análise do antisemitismo", In: VIEIRA, Nelson H. (org.). Op. Cit., 1994, p. 101.

${ }^{82}$ Cf. Nathan Abrams, "'America is Home' Commentary Magazine and the Refocusing of the Community of Memory, 1945-1960", In: Murray Friedman (editor), Commentary in American Life, Philadelphia, Temple University Press, 2005, p. 12.
} 
no sentido de se cooperar com o chamado para estudos mais aprofundados sobre antissemitismo e outras formas de preconceito religioso e racial em conexão com a resolução sobre antissemitismo adotada pelas Nações Unidas através da subcomissão sobre Prevenção de Discriminação e Proteção das Minorias ${ }^{83}$. Solicitava-se informação e análise de organizações privadas tais como o AJC. Em Buenos Aires Maximo Yagupsky, representante do AJC, reuniria tais informações assim como Abraham Monk no Rio de Janeiro ${ }^{84}$.

Subjacente ao combate ao racismo, antissemitismo e totalitarismo emergia uma espécie de consciência étnico/cultural judaica que distinguia Commentary da Partisan Review. Esse novo olhar associado ao combate ao comunismo implicou numa reconfiguração do intelectual orgânico e universal de origem judaica que em terras americanas se distanciou cada vez mais do radicalismo libertário/revolucionário, tornando-se um intelectual judeu voltado para estudos "culturais", tendência da esquerda americana ${ }^{85}$. A revista resultou num espaço de registro dessa transformação que começou nos anos de 1930 e se estendeu por todo o período da Guerra Fria envolvendo, uma série de fatores. Assim, consideramos oportuno avaliar 0 desempenho desses intelectuais judeus, conhecidos a partir de 1960 como os New York

\footnotetext{
${ }^{83}$ O documento não cita número nem data da resolução. Criada em 1947 sob a autorização do ECOSOC (Conselho Econômico e Social das Nações Unidas), essa subcomissão é o principal órgão subsidiário da Comissão para os Direitos Humanos. Em 1999, o ECOSOC alterou-lhe o nome de Subcomissão para a Prevenção da Discriminação e Proteção das Minorias para Subcomissão para a Promoção e Proteção dos Direitos Humanos. A Subcomissão tem por principal função a elaboração de estudos e recomendações à Comissão relativas à prevenção da discriminação no âmbito dos direitos humanos e liberdades fundamentais e proteção das minorias raciais, nacionais, religiosas e lingüísticas. Cf. http://www.fd.uc.pt/hrc/enciclopedia/onu/subcomissao.htm, acesso em 10/11/2010. ${ }^{84} \mathrm{O}$ primeiro registro de ajuda financeira do $A J C$ à comunidade brasileira é de 1938. Os primeiros contatos com o AJC no Brasil se deram em 1936 através do Dr. Ludwig Lorch em São Paulo, que transmitia informações sobre os eventos no país. Lorch foi uma figura muito importante na ajuda aos imigrantes no período da Guerra tendo sido um dos fundadores da Congregação Israelita Paulista (CIP) e seu presidente até 1942. Em 1938, entre março e agosto o AJC enviou U\$3000,00 para fins educacionais através do médico conhecido por Luis Lorch. A respeito desta ajuda ver "Activities of the American Jewish Committee in Latin America", 5 de novembro de 1940, The Amercan Jewish Committee, p. 4, In: www.ajcarchives.org/ajarchive/DigitalArchive.aspx, acesso em 25/02/2011.

${ }^{85}$ A respeito dessa "mudança de função" dos "New York intellectuals" utilizamos a análise apoiada nos trabalhos de Antonio Gramsci e Michel Foucault de Nathan Abrams, que concluiu que através da aliança com a hegemonia anticomunista, muitos deles perderam suas funções originais enquanto intelectuais "orgânicos" e "universais" tornando-se ao invés disso, tradicionais e específicos. Ver o artigo de Nathan Abrams, "A Profoundly Hegemonic Moment: De-Mythologizing the Cold War New York Jewish Intellectuals". Shofar: An Interdisciplinary Journal of Jewish Studies - Volume 21, Number 3, Nebraska, University of Nebraska Press, Spring 2003, pp. 64-82.
} 
intellectuals, cuja atuação deve ser compreendida na paisagem política da chamada Guerra Fria Cultural ${ }^{86}$.

\section{3 - A intelectualidade judaica americana e a guerra fria cultural}

Ao invés disso, sente-se que para ele, como para nós, talvez não haja lugar para onde ir, nem há em nossa terrível situação nada concreto a que realmente se possa opor resistência. Entretanto, saímos com a noção de que onde há vida, há escolha, e de que onde há alternativa para decidir há também a possibilidade de que nós também possamos vir a ser chamados, um dia, para prestar contas por decisões que não tomamos, por oportunidades que talvez tenhamos desprezado, por alternativas que tenhamos desconhecido por estar demasiadamente cegos. ${ }^{87}$

Commentary se tornou uma revista influente na vida americana de um modo geral, tendo desempenhado importante papel enquanto veículo de ideias que contribuiu para o esforço anticomunista. Em seu artigo "America is Home", Nathan Abrams afirmou que o primeiro editor de Commentary, Elliot Cohen (editor entre 1945-1960), criou um discurso associado aos intelectuais "Americanos Judeus" ou New York Intellectuals"88 - como ficariam conhecidos.

\footnotetext{
${ }^{86}$ Para uma discussão sobre esse processo culturalista que teve início nos Estados Unidos e que envolveu os movimentos sociais e o seu abandono do universalismo próprio dos posicionamentos de esquerda sugiro o interessante artigo de Lindgren Alves, cônsul geral do Brasil em São Francisco (EUA) na época da redação do texto. J. A. Lindgren Alves, "Excessos do Culturalismo: pós-modernidade ou americanização da esquerda?", In: Impulso - Revista de Ciências Sociais e Humanas: Modernidade e Pós-modernidade, n. 29, vol. 13, Piracicaba: Editora da UNIMEP, 2001, pp. 63-81.

87 Jason Epstein, "O Julgamento de Nuremberg: Comentários sobre um filme", In: Comentário, ano III, n. 2, abr-mai-jun, 1962, p. 184.

${ }^{88}$ De acordo com Norman Podhoretz, editor-chefe de Commentary a partir de 1960, o termo foi criado pelo crítico Irwing Howe embora nem todos fossem de Nova lorque. Cf. Norman Podhoretz, Ex-Friends. Falling out with Allen Guinsberg, Lionel and Diana Trilling, Lillian Hellman, Hannah Arendt, and Norman Mailer, California: Encounter Books, 2000, p. 12. Howie preferia o termo à "New York Intellectual Family" também utilizado, que consistia em: Elliot Cohen, Sidney Hook, Philip Rahv, Lionel Trilling, Meyer Schapiro, William Phillips, Hannah Arendt, Diana Trilling, Alfred Kazin, Richard Hofstadter, Saul Bellow, Delmore Schwartz, Bernard Malamud, Harold Rosenberg, Clement Greenberg, Lionel Abel, Paul Goodman, Isaac Rosenfeld, Daniel Bell, Irving Howe, Leslie Fiedler, Robert Warshow, Gertrude Himmelfarb, Irving Kristol, Melvin Lasky, Nathan Glazer, S. M. Lipset, David Bazelon, Norman Podhoretz, Steven Marcus, Robert Brustein, Midge Decter, Jason Epstein, Robert Silvers, Susan Sontag, Theodore Solotaroff, Norman Mailer e Phillip Roth. Esta lista foi elaborada por Daniel BELL, "The 'Intelligentsia' in American Society", In: Sociological Journeys: Essays 1960-1980, London, Heinemann, 1980, pp. 128-129.
} 
A pesquisa desenvolvida por Frances Stonor Saunders intitulada "Who paid the piper" (Quem pagou a conta? - na tradução brasileira) fornece dados contundentes a respeito do papel que a Central Intelligence Agency (CIA) desempenhou no financiamento de personalidades de centro e esquerda, bem como de publicações que criticassem o marxismo e o comunismo com 0 objetivo de afastar a intelligentsia destas correntes de pensamento aproximando-a do American Way of Life e dos valores embutidos na sua configuração, que proporcionariam uma maior aceitação da política externa norte-americana. Este projeto do governo norte-americano reuniu pessoas extremamente influentes que integraram o serviço de informações, além de estrategistas políticos, personalidades do meio empresarial e antigos laços estudantis das universidades da Ivy League ${ }^{89}$.

Durante a década de 1930, radicais e intelectuais de esquerda decepcionados com o totalitarismo stalinista integraram este grupo. A desilusão com o comunismo e a queda da confiança que depositavam no marxismo se associou ao desejo de fazer parte de uma proposta de uma nova ordem. Neste momento a tradição intelectual de oposição radical dedicada à investigação de mitos e indagação de prerrogativas institucionais foi suspensa em favor do liberalismo norte-americano articulado através da Doutrina Truman e do Plano Marshall (1947). Muitos desses intelectuais foram subsidiados pela $C / A^{90}$, pois em determinado momento dividiram interesses comuns ${ }^{91}$. Participaram assim, uns sabendo, outros não, da Guerra Fria ideológica cuja atuação estratégica tal qual do lado soviético - muito se valeu de uma propaganda política que tinha a cultura como "arma operacional" - neste caso a americana - com o objetivo de estabelecer-se enquanto paradigma.

A América significou uma alternativa para aqueles que vivenciaram a guerra na Europa, um lugar para reconstruir a vida longe dos destroços e da miséria do Velho Mundo arrasado. Para os judeus, a América significou mais

\footnotetext{
${ }^{89}$ Frances Stonor Saunders. Op. Cit., 2008, p. 13. Sobre a história do anticomunismo norteamericano, ver Richard Gids Powers. Not Without Honor: the History of American Anticommunism. Yale, Yale University Press, 1998; M. J. Heale, American Anticomunism: Combating the Enemy Within, 1830-1970. Baltimore, Johns Hopkins, 1990.

${ }^{90}$ A CIA foi criada pela Lei de Segurança Nacional em 26 de julho de 1947, com o objetivo de coordenar informações militares e diplomáticas, sua atuação extrapolou em muito seus objetivos iniciais, sendo a Agência marcada por um histórico de intervenções abusivas dentro e fora dos Estados Unidos.

${ }^{91}$ Frances Stonor Saunders. Op. Cit., 2008, pp. 14 e 15.
} 
do que isso, significou um lar, uma pátria, um refúgio. $O$ apego que os judeus desenvolveram pelo Novo Mundo se deve ao papel de esteio que este desempenhou quando havia apenas duas alternativas na Europa: fugir e viver ou ficar e morrer. Para alguns intelectuais judeus emancipados a América passou também a ser um lugar onde se podia estar ao lado de quem lutava contra o absurdo nazista. A retomada das raízes ou traços culturais judaicos também pode ser avaliada como associada diretamente a este processo enquanto uma reação intelectual em protesto à tentativa deliberada de apagamento de uma cultura por meio de assassinato em massa de um povo.

É fundamental destacar que se chamavam de judeus (ainda hoje), inclusive os assimilados e ateus; indivíduos que, apesar de suas raízes ancestrais serem judaicas, não professavam a religião mosaica nem praticavam nada associado a nenhuma tradição ou rito de origem judaica. Mesmo assim foram estigmatizados, taxados como judeus, marcados, nomeados pejorativamente, rotulados a despeito da visão ou classificação que faziam de si mesmos. Ou seja, nomeados e/ou identificados como judeus e tendo em seu passado um histórico traumático de perseguição pelo simples fato de "ser", natural que se buscasse a essência desta condição para significar-se dentro de uma ancestralidade, além de (re)elaborar o trauma de ser alvo de tanta agressividade e ódio.

Portanto os estudos sobre $\mathrm{O}$ antissemitismo financiados pelo $A J C$ desenvolvidos a partir da década de 1940 são produtos de seu tempo, "tempos sombrios", segundo Hannah Arendt. Como tais, ficaram como um legado abrindo caminho para novas produções. Estudos em torno do tema do antissemitismo continuam sendo desenvolvidos no meio universitário de muitos países reunindo especialistas de diferentess áreas do conhecimento dedicados a registrar e analisar as manifestações antissemitas ao longo da história e, em especial, no mundo contemporâneo. Procuram explicar as origens e os desdobramentos desse sentimento além de discutir as doutrinas (jurídicas) que justificam a criminalização dos atos e manifestações antissemitas. O grupo de Horkheimer já citado, subsidiado pelo $A J C$, foi precursor destes estudos.

Nas décadas de 1920 e 1930, Nova lorque concentrava uma grande parcela da comunidade judaica da Diáspora que, ao longo dos anos fixou-se definitivamente na América do Norte. Para os intelectuais judeus nova- 
iorquinos (muitos dos quais de esquerda) uma sucessão de decepções em relação à União Soviética serviu-Ihes de desestímulo e os afastou do comunismo e marxismo, levando-os a confiar nos Estados Unidos onde ainda se podia viver em segurança e apostar no seu projeto de nação, político liberal. Tais decepções foram provocadas por um conjunto de fatos, como por exemplo, o julgamento de Leon Trotski por traição em 1936-1937, o pacto de não agressão ou pacto germano-soviético (1939) e uma série desastrosa de erros políticos, teóricos e de julgamento cometidos por Stálin ${ }^{92}$.

Grande parte dos New York Intellectuals identificados por Daniel Bell que também era um deles, autor de The end of Ideology [O fim da Ideologia] sofreu uma guinada radical do marxismo ao neoconservadorismo, incluindo a "nova esquerda" crítica do stalinismo. Entre eles esteve Melvin Lasky (judeu nascido no Bronx em 1920), militante político anti-stalinista que atuou ao lado de Michael Josselson (oficial norte-americano de origem estoniano-russa, excomprador de uma loja de departamentos) e Nicolas Nabokov (compositor bielo-russo que chegou aos Estados Unidos em 1933) integrante de uma das mais ambiciosas operações secretas da Guerra Fria: "conquistar a intelectualidade ocidental para a proposta norte-americana", segundo a narrativa de Saunders. Melvin Lasky antes havia integrado a equipe da revista anti-stalinista New Leader e, mais tarde, tendo servido o exército dos Estados Unidos, foi para Berlim onde se tornou correspondente da New Leader e da Partisan Review na Alemanha. ${ }^{93}$

Foi através do Congress for Cultural Freedom (CCF), criado em Berlim em 1950 em resposta aos congressos comunistas realizados em 1949 no Waldorf Astoria Hotel em Nova lorque e em Paris, que se empreendeu o afastamento da intelectualidade ocidental da admiração que ainda restava em relação ao marxismo e ao comunismo ${ }^{94}$. Os congressos comunistas fizeram parte da campanha pela paz mundial, cuja inauguração se deu com a Cultural Conference for Peace de Breslau em 1948, que associava a Doutrina Truman

\footnotetext{
${ }^{92}$ Idem, p. 70.

${ }^{93}$ Idem, p. 42-45.

${ }^{94}$ Sobre as origens do Congresso para a Liberdade Cultural conferir o artigo de M. Warner. Origins of the Congress for Cultural Freedom, 1949-50. www.cia.gov./csi/kent csi, acessado em 9/06/2010.
} 
ao fascismo ${ }^{95}$. O CCF tinha escritórios em 35 países, incluindo o Brasil, e foi dirigido pelo já citado Michael Josselson, agente da CIA, de 1950 a 1967. Entre as atividades desempenhadas pelo Congresso para atingir seu objetivo, estava a realização de conferências internacionais, exposições, concertos, premiações de músicos e artistas. O congresso contava com um serviço de notícias e publicava mais de vinte revistas de prestígio ${ }^{96}$.

A CIA atuava por meio de fundações filantrópicas como a Farfield, Ford, Rockefeller e Kaplan. Sua intromissão em fundações desse tipo foi intensa na década de $1950^{97}$. Ela subsidiava todas as atividades do Congresso por meio das fundações, em especial a Farfield, bem como subsidiava publicações norte-americanas do mesmo modo.

Criado em Nova lorque em 1951, o American Committee for Cultural Freedom foi presidido pelo filósofo Sidney Hook, tendo Irving Kristol como seu diretor executivo, ambos colaboradores de Commentary, sendo que Kristol havia se tornado editor-chefe da revista em $1947 .{ }^{98}$ Kristol também foi editor da Encounter, a revista intelectual patrocinada pelos serviços secretos americano e britânico ${ }^{99}$ onde escreveram "as maiores cabeças pensantes" de 1953 a 1990 e foi lida na Inglaterra, nos Estados Unidos, na Ásia e na África. O CCF patrocinou revistas em todo o mundo, com o mesmo perfil cultural e agregando desertores dos Partidos Comunistas locais. $\mathrm{Na}$ Itália subsidiou Tempo Presente, na Índia, Quest, na Austrália, Quadrant, no Japão, Jiyu, entre outras, como a Cuadernos, lançada em 1953 em Paris, sob a tutela editorial do romancista e teatrólogo Julian Gorkin, e dirigida aos intelectuais latinoamericanos.

No Brasil foi criada a revista Cadernos Brasileiros (1959-1970) fundada pelo CCF. Em 11 de abril de 1958, quarenta e dois intelectuais brasileiros e estrangeiros residentes no país fundaram a Associação Brasileira do Congresso pela Liberdade da Cultura. Entre eles citamos os nomes de Alceu

\footnotetext{
${ }^{95}$ Elizabeth Cancelli. "Intelectualidade e Poder: inconformidade na Guerra Fria, Revista ArtCultura, Uberlândia - MG, n. 9, jul-dez. de 2004, p. 114.

${ }^{96}$ Frances Stonor Saunders. Op. Cit., 2008, p. 13.

${ }^{97}$ Idem, p. 152. Ver listagem das fundações na p. 153.

${ }^{98}$ Kristol fez amizade na faculdade (City College) com Irwing Howe, Daniel Bell e Melvin Lasky, envolvendo-se com os Trotskistas e com a Liga Socialista dos Jovens, uma organização anticomunista de esquerda. Ajudou a editar a revista Enquiry (ex-trotskista). Ver: Idem, pp.190191.

${ }^{99}$ Idem, p. 189.
} 
Amoroso Lima (Tristão de Athayde), Manuel Bandeira, Austregésilo de Athaíde, João Guimarães Rosa, Cecília Meireles e Érico Veríssimo ${ }^{100}$, muitos dos quais também escreviam na revista Comentário.

Elliot Cohen, editor de Commentary era considerado um intelectual anticomunista conservador de nível "elevado". Para Saunders, "(...) a sede do anti-stalinismo 'profissional' era o Comitê Norte-Americano pela Liberdade Cultural, bem como as revistas cujos editores participavam de sua diretoria, a saber, Commentary, New Leader e Partisan Review."101

Desse modo, Commentary, se encaixa no perfil das muitas publicações que reuniam figuras alinhadas ao pensamento de esquerda e que atuaram no favorecimento da política anticomunista norte-americana, estando ligada ao CCF através de seus editores que faziam parte da diretoria do American Committee for Cultural Freedom (Comitê Norte-Americano pela Liberdade Cultural).

Segundo classificação de George H. Nash, Commentary passou por três fases ideológicas. A primeira (1945-1959), sob o comando de seu editorfundador Elliot Cohen, foi descrita como liberalismo da Guerra Fria. A segunda (1960-final dos anos 1960), sob Norman Podhoretz, pode ser chamada de leftliberalism (liberalismo de esquerda) ou New Leftism (Novo Esquerdismo). A terceira, iniciada por Podhoretz em 1970 foi uma fase de repúdio a segunda e um "assalto à esquerda em todas as suas formas", e foi nomeada de neoconservadorismo vigorando até os dias de hoje ${ }^{102}$.

Foi, sob o comando de Norman Podhoretz, que assumiu em 1960 a edição da "matriz" Commentary, que Comentário vigorou. Podhoretz foi o responsável pela revista americana durante a sua segunda e terceira fase até 1995. Ele foi considerado uma das mais destacadas vozes do neoconservadorismo americano tendo, no entanto, no início, em 1960, tornado a revista um veículo da New Left (Nova Esquerda). Aos poucos ficou cada vez mais preocupado com os perigos que a esquerda poderia representar para 0

\footnotetext{
${ }^{100}$ Cf. lista completa em Kristine Von Berghe. Intelectuales y anticomunismo: La revista "Cadernos Brasileiros" (1959-1970). Leuven: Leuven University Press, 1997, p. 55 apud, Elisabeth Cancelli. Op. Cit., 2004, p. 115.

${ }^{101}$ Ver Frances Stonor Saunders. Op. Cit., 2008, pp. 180-182. Ainda, a estratégia de fortalecer a esquerda não-comunista empregada pela CIA teve sua lógica exposta por Arthur Schlesinger em seu livro The Vital Center (1949), apud Idem, p. 79.

${ }^{102}$ George H. Nash, "Joining the Ranks", In: Murray Friedman (editor), Op. Cit., 2005, p. 152.
} 
Ocidente, especialmente para o Estado de Israel em guerra ${ }^{103}$. De sua fundação em 1945 a 1968 Commentary foi uma revista liberal tornando-se uma revista conservadora ao longo dos anos de 1970 e início dos anos de 1980 e um componente-chave do movimento neoconservador judaico ${ }^{104}$. No final dos anos 1970 Podhoretz foi uma das vozes do revival anticomunista muito relacionada com o antiamericanismo surgido a partir da Guerra do Vietnam, que o mobilizou a romper com a esquerda considerada por ele como "infectada pelo antiamericanismo". Após a Guerra dos Seis Dias em 1967, a esquerda passou a mudar a sua posição pró-Israel. Esses dois fatores induziram, certamente, Podhoretz a voltar-se, paulatinamente para a direita ${ }^{105}$.

\section{A Retórica Apocalíptica da Guerra Fria}

Uma angústia de aniquilamento da época aparece em todos os âmbitos da cultura na revista Comentário como, por exemplo, da dramaturgia do período. Citamos a análise que Leo Gilson Ribeiro faz a respeito de lonesco e do teatro de vanguarda francês, nomeando Eugene lonesco, Bertold Bretch e Beckett de cronistas do absurdo, "sombrios dramaturgos são os documentadores da angústia de uma humanidade sobre a qual se ergue 0 cogumelo negro da explosão atômica" (p. 247). Essa mesma "tragédia" - de "um pavor físico universal" foi também descrita pelo escritor norte-americano William Faulkner:

“... nossa tragédia, hoje, é um pavor físico universal que nos pesa há tanto tempo que já não o podemos suportar mais. Só nos resta a pergunta. Quando seremos atomizados?... Negome a aceitar o fim do Homem. Acredito que não somente o Homem vai resistir, mas que vai prevalecer..." William Faulkner, discurso de Estocolmo. ${ }^{106}$

\footnotetext{
${ }^{103}$ Cf. Murray Friedman, "Introduction. Comentary: The First Years", In: Murray Friedman (editor), Op. Cit., 2005, p. 4.

${ }^{104}$ Fred Siegel, "Commentary and the city", In: Murray Friedman (editor), Op. Cit., 2005, pp.7879.

${ }^{105}$ Richard Gid Powers, "Norman Podhoretz and the Cold War", In: Murray Friedman (editor), Op. Cit., 2005, pp.147-149.

${ }^{106}$ Apud Charles Astor, "William Faulkner", In: Comentário, Ano IV, n. 1, 1963, p. 90.
} 
Essa angústia tornou-se uma constante durante o período em que vigorou a divisão do mundo em dois blocos político-ideológicos: o comunista e o capitalista. O papel dos intelectuais na manipulação das ideias em defesa de um dos lados foi claramente demarcado em Comentário que, no segundo trimestre de 1962, reproduziu um debate entre Herman Kahn, influente advogado da defesa civil, versus Erich Fromm, psicólogo e Michael Maccoby a respeito da possibilidade iminente de uma guerra nuclear e o desaparecimento da humanidade, reproduzido da revista Commentary de janeiro de 1962. O tom dramático revelou Maccoby imaginando, como algo viável, as pessoas vivendo no pós-guerra sob contaminação. O debate retrata bem a paranóia típica do período da Guerra Fria, quando persistia o medo de atacar pensando que seria atacado e todo o trabalho ideológico de defesa dos ideais e instituições do Ocidente em detrimento do Oriente.

Segundo Fromm e Maccoby o despertar destas inquietações se deu em 1961 devido à aguda crise de Berlim e ao discurso do presidente Kennedy a 25 de julho relatando seu encontro com Krushev. Eles questionaram a eficácia da defesa civil (o presidente havia proposto em seu discurso um novo programa de abrigos no valor de 207 milhões de dólares) apontando diversas restrições e sugerindo, ao invés disso, o desarmamento universal e acordos políticos ${ }^{107}$.

Essa questão foi retomada em escala maior, num debate coordenado por Norman Podhoretz entre Sidney Hook, H. Stuart Hughes, Hans J. Morgenthau e C. P. Snow ${ }^{108}$ promovido por Commentary e reproduzido em 1963 em Comentário. No debate ocorrido no auditório do Instituto de Relações Humanas estiveram presentes escritores, publicistas, sacerdotes e educadores. O que se discutiu na verdade foram os valores do Ocidente então em cheque diante da possibilidade de guerra total. Duas escolas de pensamento se opunham: a do já citado Herman Kahn que encarava a possibilidade do uso das armas nucleares e calculava a reconstituição de uma

\footnotetext{
107 "Herman Kahn versus Erich Fromm e Michael Maccoby, "A Guerra Nuclear e a Sobrevivência Humana - Um Debate", In: Comentário, ano III, n. 1, 1962, pp. 103-124.

${ }^{108} \mathrm{Na}$ época ocupavam as funções de, respectivamente, chefe do Departamento de Filosofia da Universidade de Nova York, Professor de História em Harvard, Diretor da Seção bimestral "Public Affairs" de Commentary, também Diretor do Centro de Estudos Sobre Política Estrangeira na Universidade de Chicago e finalmente o autor do ensaio The Two Cultures and The Scientific Revolution.
} 
civilização após a guerra, e a de Karl Jaspers que entendia não ser possível falar na preservação da civilização, da liberdade ou valores se uma guerra desse porte ocorresse, defendendo a eliminação da guerra nuclear como instrumento de política nacional. A ideia de rendição significava um mundo livre avassalado pelo comunismo. Dessa discussão surgiu o dilema: red or dead? Apareceram as sugestões de um desarmamento multilateral e controle internacional através de um organismo supranacional de fiscalização sobre as armas termonucleares. Mas o que chama mais atenção é a certeza de uma não razoabilidade comunista em detrimento do bom senso americano tal como na fala paranóica de Irving Kristol:

O que o Sr. Hughes afirma se bem o entendi, é que do ponto de vista russo-comunista, não tem sentido dominar um mundo onde exista a ameaça de destruição termonuclear e que os comunistas consideram justificável entrar num acordo sobre desarmamento nuclear. Por conseguinte, a questão é saber por que não o fazem. Pessoalmente, creio que não o fazem por serem comunistas, por não serem razoáveis, por haver no comunismo mitos que ditam a sua política. ${ }^{109}$

As divergências entre União Soviética e Estados Unidos foram retomadas no primeiro trimestre de 1964 através do artigo "Além de Berlim Existirá um Novo 'Equilíbrio de Forças'”, de Theodore Draper, também colaborador da revista Encounter ${ }^{110}$. Comentário reproduziu os debates transcritos e artigos publicados em Commentary onde o discurso anticomunista era incentivado pelos serviços secretos americano e britânico representados por figuras como Sidney Hook e colaboradores da revista Encounter.

Comentário surgiu em 1960 com a proposta discursiva de Cohen consolidada. Esta consistia, segundo Abrams, entre outras coisas, em redirecionar a memória judaica através do uso de uma "desejável seletiva amnésia" em relação aos preconceitos sofridos pela comunidade nas décadas anteriores de modo a quase não criticar os problemas americanos e associar a imagem dos Estados Unidos à tolerância. A identidade judaica deveria ser

\footnotetext{
${ }^{109}$ Irving Kristol, ex-Diretor de Commentary, Diretor associado de Encounter, de Londres, Diretor do Reporter, em "Os Valôres do Ocidente e a Guerra Total" - um debate, In: Comentário, ANO IV, n. 1, 1963, p. 43

${ }^{110}$ As referências dos artigos de Comentário citados estão em: Anexos, na Tabela de Autores Internacionais.
} 
reelaborada a fim de caber no modelo americano do contexto da Guerra Fria. A revista passou a preencher a lacuna criada depois que muitos acadêmicos abandonaram o marxismo. Esse modelo ou influência foi transposto para o Brasil através de Comentário, cujas nuances e particularidades são avaliadas neste trabalho ${ }^{111}$.

Assim como nos Estados Unidos, no Brasil, as dificuldades sofridas pelos judeus - desde as diplomáticas relacionadas à sua entrada no país durante a Segunda Guerra Mundial ${ }^{112}$ até as perseguições das décadas de 1930 e 1940 pela Polícia Política enquanto estrangeiros associados ao comunismo durante o governo de Getúlio Vargas ${ }^{113}$ - não foram mencionadas pela revista, embora ela reunisse nomes de judeus que haviam sido fichados pelo Deparatamento de Ordem Política e Social (DEOPS/SP) na década de 1940. Este silêncio, segundo Tucci Carneiro, justifica-se pelo fato da comunidade judaica ter optado por não discutir abertamente o tema do antissemitismo e da prática das circulares secretas. Enfim, uma estratégia para facilitar a entrada e a adaptação dos refugiados do nazismo em terras brasileiras. A recente historiografia brasileira tem demonstrado que, somente após a década de $1970^{114}$, é que este silêncio começou a ser rompido com a publicação dos primeiros estudos sobre o tema, dependendo ainda da abertura dos arquivos diplomáticos e policiais ocorridos em $1995 .^{115}$

Este silêncio (ou omissão) pode ser constatado em alguns artigos da revista Comentário que, por exemplo, chegou a retratar a imagem "heróica" de

\footnotetext{
${ }^{111}$ Nathan Abrams, “'America is Home”: Commentary Magazine and the Refocusing of the Community of Memory", 1945-1960", In: Murray Friedman (editor), Op. Cit., 2005, pp.33 e 34.

${ }^{112}$ Maria Luiza Tucci Carneiro, op. cit., $2^{\mathrm{a}}$ ed., 2001 e Maria Luiza Tucci Carneiro, "Cidadão do Mundo. O Brasil diante da Questão dos Refugiados Judeus (1933-1945)". Tese de Livredocência, FFLCH/USP, 2001.

${ }_{113}$ Cf. Elizabeth Cancelli, O Mundo da Violência: a Polícia da Era Vargas, Brasília, Editora Universidade de Brasília, 1993, pp. 125-130; Taciana Wiazovski, Bolchevismo e Judaísmo: a Comunidade Judaica sob o Olhar do DEOPS, Módulo VI - Comunistas, Organizado por Maria Luiza Tucci Carneiro, São Paulo, Arquivo do Estado/Imprensa Oficial, 2001, (Coleção Inventário DEOPS); e O Mito do Complô Judaico-Comunista: Gênese, Difusão e Desdobramentos (1907-1954). São Paulo: Humanitas, 2008. Originalmente apresentada como Dissertação de mestrado, FFLCH, USP, Depto de Letras Orientais, 2005.

${ }_{114}$ Cf. análise da historiografia nacional a respeito do racismo contra cristãos-novos feita por Maria Luiza Tucci Carneiro em Preconceito Racial e Brasil Colônia, São Paulo, Perspectiva, 2005, pp. 22-28.

${ }^{115}$ Importante lembrar que o Arquivo Histórico do Itamaraty e os Fundos DOPS/DEOPS somente foram abertos para consulta pública a partir de 1995, data que marcou a produção historiográfica sobre o antissemitismo no Brasil e, em especial, durante o governo Vargas e Dutra. Ver citações na Bibliografia final.
} 
Oswaldo Aranha como "grande estadista (...), um símbolo da coerência do Brasil com a sua própria história e suas mais generosas tradições." ${ }^{116}$ Hoje, tal versão se faz contraditória e até mesmo polêmica tendo em vista os estudos desenvolvidos por Tucci Carneiro (2001), Jeffrey Lesser (1995), Avraham Milgram (1994) Leonardo Senkman (1994), Fábio Koifman (2002), Maria das Graças Athayde de Almeida (2001), Taciana Wiazovski (2008) e Anna Rosa Bigazzi.

Comentário reuniu alguns dos intelectuais que na década de 1930 foram "recrutados das famílias da classe dirigente", portanto antigos no "campo de produção cultural"117 em São Paulo e Rio de Janeiro, principalmente. Sua produção os aproximou da nova categoria intelectual: os judeus radicados no Brasil, imigrantes e filhos de imigrantes, porta-vozes do discurso da tolerância e da democracia. Cabe lembrar que neste contexto delineado pelo período do autoritarismo, xenofobia e nacionalismo exacerbado, projetou-se por parte do Estado e das correntes identificadas com as ideologias de direita, um forte sentimento anticomunista cujas raízes remontam ao início do século XX. Por força dos mitos políticos, persistiu no Brasil a imagem do comunista aliado ao judeu subversivo, representações manipuladas pelo discurso oficial da Igreja Católica, como pude constatar em meus estudos que analisam o processo de construção do mito do complô judaico-comunista no Brasil ${ }^{118}$.

Rodrigo Patto Sá Motta, em estudo sobre as representações do anticomunismo no Brasil, atentou para a forte presença do imaginário antissemita ao analisar a onda de xenofobia no Brasil nos anos de 1930, em que identificou o destaque da vertente antissemita em meio às representações do anticomunismo ligado à ação de estrangeiros ${ }^{119}$.

Destaque-se desde já, no entanto, que o anticomunismo vinculado à esquerda no Brasil não teve o mesmo desenvolvimento que nos Estados Unidos e na Europa. Para Rodrigo Patto Sá Motta o quadro de pobreza e atraso social brasileiro tornava constrangedor opor-se e/ou combater o projeto

\footnotetext{
${ }^{116}$ Ver o artigo que reproduziu o discurso proferido pelo Embaixador do Brasil em Israel em 1967 por ocasião da inauguração do "Centro Cultural Oswaldo Aranha" no kibutz "Bror Chail". Aloyísio Régis Bittencourt, "Brasil-Israel”, In: Comentário, Ano VIII, n. 2, 1967, p. 108.

${ }^{117}$ Cf. Sérgio Miceli, Op. cit., 2001

${ }_{118}$ Cf. Taciana Wiazovski. Op. Cit., 2008.

${ }^{119}$ Rodrigo Patto Sá Motta, Em Guarda contra o Perigo Vermelho, São Paulo, Editora Perspectiva, 2002, pp. 56-61.
} 
comunista. Ainda, segundo o autor, o anticomunismo ficou fortemente associado aos grupos reacionários e conservadores, de modo que assumir uma postura anticomunista significava um dilema político ${ }^{120}$.

\section{4 - American Jewish Committee e o combate ao comunismo}

No início dos anos 1950 Israel se alinhava ao Ocidente. Antes disso, no entanto, desde o início de 1947, a alegada associação entre judeus e comunismo foi amplamente considerada pelo Comitê Executivo do $A J C^{121}$, nos Estados Unidos. Nessa época, a consultora Selma G. Hirsh, vinculada ao AJC desde 1945, reconhecida hoje como uma defensora da causa humanitária, avaliou a questão sob o prisma da segurança dos judeus que estaria inextricavelmente amarrada à segurança da sociedade democrática, sociedade através da qual a dignidade individual e a segurança econômica deveriam ser alcançadas. Esta sociedade estaria ameaçada por duas forças: de um lado, conjugados estariam os reacionários, pró-fascistas e fascistas e, de outro, as forças da extrema esquerda (comunistas e afins). Dessa forma Selma G. Hirsh propôs que o trabalho do $A J C$ deveria ser o de travar uma luta contínua contra a esquerda e a direita alinhando-se politicamente às forças liberais no país ${ }^{122}$.

Em 1950 o $A J C$ criou um programa - divulgado em agosto daquele ano para os responsáveis por sua condução e difusão - visando dissociar os significantes judeus e comunismo no imaginário social e combater 0 comunismo entre os Judeus. Para atingir estes objetivos registrou-se ter havido uma grande mobilização por parte da instituição conforme alguns documentos produzidos pelo AJC. Este teria produzido um extenso conjunto literário e

\footnotetext{
120 Ídem, pp.16 e 17.

${ }^{121} \mathrm{Cf}$. Memorandum (confidential) to Domestic Affairs Committee, in Political Philosophy/Communism AJC Program File, AJC Subject Files Collection. Memoranda on alleged association of anti-semitism and communism, 11/08/1950, p. 1, In: www.ajcarchives.org/ajarchive/DigitalArchive.aspx, acesso em 12/01/2011. ${ }^{122}$ Cf. Memorandum (personal and confidential) to John Slawson from Selma G. Hirsh, 3/04/1947, In:

Political Philosophy/Communism Statements and Policy File, AJC Subject Files Collection. Memoranda and Policy Statements, 1947-1954 (6), p. 1, In: www.ajcarchives.org/ajarchive/DigitalArchive.aspx, acesso em 25/02/2011.
} 
conduzido diversas campanhas educativas na sociedade americana em geral e no meio judaico comunitário (panfletos, brochuras, memorandos, o American Jewish Year Book, artigos em periódicos). Dois livros descritos como "monumentais" foram preparados pelo AJC e publicados pela Syracuse University Press: The Jews in the Soviet Union de Solomon M. Schwartz (1951) e The Jews in the Soviet Satellites (1953). Tais volumes eram as fontes principais de informação a respeito do que estaria acontecendo aos judeus por detrás da Cortina de Ferro. ${ }^{123}$

O Memorandum a respeito do "Program on Communism", redigido por $\mathrm{S}$. Andhil Fineberg, em nome do $A J C$ inicia com a afirmação de que este sempre condenou o Comunismo como um sistema de governo e sociedade monolítico e totalitário, tendo se tornado em 1951 um membro do All American Conference to Combat Communism, que incluía sessenta organizações nacionais. Ainda de acordo com o documento, o AJC teria desempenhado um papel importante no combate à propaganda comunista nos Estados Unidos e também no âmbito internacional. Os artigos anticomunistas de Commentary foram citados assim como outras publicações do $A J C$ e suas declarações públicas a respeito do comunismo teriam sido amplamente citadas na imprensa.

Afirmando que em virtude de sua posição enquanto uma organização anticomunista conhecida e estimada pela Igreja, por organizações de veteranos, trabalhistas e outras, $\mathrm{S}$. Andhil Fineberg destacava que o AJC contribuiria largamente no combate aos esforços antissemitas de identificação dos judeus aos comunistas no imaginário social. ${ }^{124}$ Dessa forma, para o AJC, combater 0 comunismo significava em grande medida lutar contra 0 antissemitismo e a revista Commentary era um instrumento desse programa: "[...] 2) Commentary ran several articles on the incompatibility of Judaism and Comunism, as well as the genuine threat of Communism to freedom-loving people everywhere $[\ldots]^{p 125}$.

\footnotetext{
${ }^{123}$ Cf. "The American Jewish Committee Memorandum" from S. Andhil Fineberg to Eleanor Ashman, Subject: Brief Statement of AJC program on Communism, 1/08/1956, p. 1, In: www.ajcarchives.org/ajarchive/DigitalArchive.aspx, acesso em 10/02/2010. ${ }_{124}$ Idem, p. 2-3.

125 Cf. Memorandum (confidential) to Domestic Affairs Committee, in Political Philosophy/Communism AJC Program File, AJC Subject Files Collection. Memoranda on
} 
No Brasil, a associação entre judeus e comunismo se deu em virtude da adesão por parte de alguns imigrantes judeus a ideologias de esquerda desde a pátria de origem e, também conseqüente à mera associação de estereótipos que amalgamados muitas vezes por meio de naturezas e afinidades imprevistas em teorias políticas de conspirações mundiais, revelavam alguns dos indesejáveis sociais entre as décadas de 1910 e 1950 Essa relação associativa foi verificada por meio de estudos aqui já citados fundamentados em fontes policiais, iconográficas, periódicas e literárias ${ }^{126}$. Em geral esse discurso nos remete a uma das matrizes básicas das representações anticomunistas que é a matriz cristã, particularmente, a católica ${ }^{127}$. Essa representação maniqueísta colocava os judeus na posição de principais artífices da revolução comunista enquanto um projeto maléfico políticoeconômico-espiritual de dominação mundial.

Assim, combater a associação comunismo/judaísmo passou a ser, uma questão central para o bem estar/ bem viver e porque não dizer, "o sobreviver" da comunidade judaica nas Américas, segundo a visão do AJC. Este combate é declarado num relatório confidencial do ano de 1962 a respeito do antissemitismo na Argentina. O relatório de nove páginas revela os dados coletados por seu redator a partir de leituras e contatos com "especialistas em Argentina", nas cidades de Washington, Nova lorque, Rio de Janeiro, São Paulo, Buenos Aires, Cidade do México e Dallas, Texas. As conversas se deram junto aos oficiais governamentais dos Estados Unidos nos Departamentos de Estado, Comércio e Embaixada dos Estados Unidos em Buenos Aires; além de oficiais governamentais tanto do Brasil quanto da Argentina, oficiais militares da Argentina, jornais e televisão dos Estados

alleged association of anti-semitism and communism, 11/08/1950, p. 4, In: www.ajcarchives.org/ajarchive/DigitalArchive.aspx, acesso em 12/01/2011.

${ }^{126}$ Cf. Taciana Wiazovski, Bolchevismo e Judaísmo: a comunidade judaica sob o olhar do DEOPS, São Paulo, Arquivo do Estado/Imesp, 2001; Taciana Wiazovski. O mito do complô judaico comunista: gênese, difusão e desdobramentos (1907-1954). São Paulo: Humanitas, 2008; Cf. ainda Rodrigo Patto Sá Motta, Op. Cit., 2002; Maria Luiza Tucci Carneiro. O Veneno da Serpente, São Paulo, Editora Perspectiva, 2003.

${ }^{127} \mathrm{~A}$ respeito das matrizes das representações anticomunistas cf.. Rodrigo Patto Sá Motta, Op. Cit., 2002, pp.18 e 19. Verificar ainda o estudo de Cláudio Aguiar Almeida. Meios de Comunicação Católicos na Construção de uma Ordem Autoritária: 1907/1937, Tese de Doutorado em História Social, São Paulo, FFLCH/USP, 2002. Este trabalho identifica na matriz anticomunista cristã a relação comunismo/judaísmo. 
Unidos e Argentina, representativos das comunidades judaicas no Brasil, Argentina e México e com residentes e ex-residentes de Buenos Aires ${ }^{128}$.

O problema do antissemitismo na Argentina foi encarado como "altamente complexo" e "muito difícil". Singman passou a tratar dos antecedentes políticos, sociais e econômicos, citando no âmbito social os organizados grupos neonazistas, o "caso Sirota"129, o grupo "Tacuara" além de outros grupos fascistas ou neo-nazistas e suas origens familiares, destacadamente aristocráticas e elitistas com importantes parentes nos governos civis e nos círculos militares.

O discurso destes grupos, segundo Singman era baseado na propaganda da identificação dos judeus com um movimento mundial comunista (mito da conspiração judaico-mundial). O relatório destacou ainda a presença de certos oficiais no Exército, Marinha e Aeronáutica que eram extremamente anti-semitas e não sofriam sanção oficial, dando suporte a grupos como "Tacuara", como o fornecimento de armas militares. Cada uma das forças militares era conhecida por possuírem violentos grupos antissemitas e, embora seus líderes fossem conhecidos, eles não foram presos ou até mesmo interrogados. Citou-se, por exemplo, o capitão Horacio Enriques Green, chefe da Polícia Federal, como notoriamente antissemita. ${ }^{130}$

O relator também traçou as causas desse ressurgimento do antissemitismo na Argentina e as atribui ao caso Eichman, em virtude da violação da integridade territorial argentina; à necessidade de culpados para a crise econômica e política argentina e ao fato da Argentina ter sido um centro da inteligência nazista e de atividades de propaganda, além de ter tido seu exército treinado por oficiais alemães durante a Segunda Guerra Mundial. Depois da guerra muitos alemães permaneceram na Argentina, e esta se tornou um refúgio de nazistas. Outras causas ainda foram levantadas.

O documento revela a postura oficial da Igreja católica neste caso, quando a revista católica Criterio passou a criticar a campanha antissemita. 0

\footnotetext{
${ }^{128}$ Report on Anti-semitism in Argentina (confidential) by Julian H. Singman, setembro de 1962 , The Amercan Jewish Committee, p. 1, In: www.ajcarchives.org/ajarchive/DigitalArchive.aspx, acesso em 10/02/2010.

${ }^{129}$ Quando uma estudante universitária judia foi capturada e torturada por um grupo neonazista. Ela era assumidamente comunista.

${ }_{130}$ Report on Anti-semitism in Argentina (confidential) by Julian H. Singman, setembro de 1962, The Amercan Jewish Committee, p. 1-4, In: www.ajcarchives.org/ajarchive/DigitalArchive.aspx, acesso em 10/02/2010.
} 
Vaticano silenciara por seis meses um dos padres que liderava o grupo Tacuara. $^{131}$

No final, o relatório contém as medidas que já haviam sido tomadas (e a serem tomadas) contra as manifestações antissemitas. Entre elas, constavam:

- continuar a exercer pressão junto ao governo civil argentino;

- procurar ajuda junto ao Departamento de Defesa e amigos católicos;

- continuar a ajudar a comunidade judaica como um todo - ou somente através do Instituto - a conduzir uma silenciosa e efetiva campanha de relações públicas a fim de explicar as características positivas da vida judaica e a contribuição dos judeus para a Argentina;

- propagar por meio de uma campanha cultural educativa de uma visão que desvinculasse o judaísmo do comunismo:

\begin{abstract}
We should urge that influential Jewish organizations, including the Instituto, launch a broad educational campaign to convince the public that Judaism as a faith and philosophy is opposed to communist ideas and practices; that the Jews could never be communists; that Jews do not represent a threat to Argentina; and that some Jews, at least, are truly interested in argentine nationalism. ${ }^{132}$
\end{abstract}

O Instituto a que o documento se refere é o Instituto Judio Argentino de Cultura e Informacion criado em $1948^{133}$, responsável pela publicação da revista Comentario argentina, do mesmo estilo da Comentário brasileira, publicada pelo Instituto Brasileiro Judaico de Cultura e Divulgação, criado em 1956. As duas revistas, argentina e brasileira, reproduziam os artigos de Commentary e de autores de destaque nacional. Convém mencionar que a relação entre o Instituto argentino e o brasileiro era direta e intensa, tendo em vista que a sede do $A J C$ na América do Sul ficava em Buenos Aires.

\footnotetext{
${ }^{131}$ Idem, pp. 4-6.

132 "Devemos insistir para que as organizações judaicas influentes, incluindo o Instituto, lançem uma ampla campanha educativa para convencer o público que o judaísmo como uma fé e filosofia se opõe às ideias e práticas comunistas, que os judeus nunca poderiam ser comunistas, que os judeus não constituem uma ameaça para a Argentina, e que alguns judeus, pelo menos, estão verdadeiramente interessados no nacionalismo argentino." Idem, p. 7.

${ }^{133}$ Cf. Program Statement of Foreign Affairs Department, p. 11, Israel/ AJC Israel Office File, Foreign Affairs Department Collection, FAD-1. Memoranda on the question of estabilishing an office in Israel, 1947-1957 (9), In: www.ajcarchives.org/ajarchive/DigitalArchive.aspx, acesso em 25/02/2011.
} 
O AJC destacou Abraham Monk ${ }^{134}$ como seu porta-voz no Rio de Janeiro. Monk relatava não apenas os acontecimentos relacionados aos judeus no Brasil, mas as medidas que o $A J C$ vinha tomando no sentido de defender os interesses da comunidade no país ${ }^{135}$.

A exemplo disso citamos as ações promovidas pelo $A J C$ na resolução de problemas com manifestações antissemitas neonazistas. Distribuiu-se um memorandum do AJC em 1959, em português, para os principais oficiais governamentais, incluindo o Presidente Juscelino Kubitschek, o Vicepresidente João Goulart e o Ministro das Relações Exteriores Horácio Lafer ${ }^{136}$, entre outros; para os principais editores e para diretores dos mais importantes jornais, além da imprensa judaica. Membros do "Instituto Judeo Brasileiro" discutiram com o Presidente e outros líderes a respeito do assunto das manifestações antissemitas. Monk era quem relatava esses acontecimentos além de informar sobre a sua participação e palestra em seminário voltado para professores judeus no Estado de São Paulo e em conferência do mesmo tipo no Rio de Janeiro, desenvolvendo atividades no seio da comunidade ${ }^{137}$.

Dessa forma, o AJC, vigiava as manifestações antissemitas, promovia a aproximação das comunidades judaicas nas Américas dos grupos dirigentes nacionais, precavendo-se e agindo no sentido de manter a figura do "judeu estrangeiro" longe das acusações e responsabilizações comumente surgidas nos momentos de instabilidade social, econômica e política. Acrescente-se ainda a isso as acusações que os judeus sofreram de traidores da pátria e marxistas (líderes do marxismo), "apátridas", expressões repetidas no livro Mein Kempf de Adolph Hitler e em toda a literatura antissemita. Daí alguns

\footnotetext{
${ }^{134}$ Monk foi membro do conselho editorial da revista In: Comentário desde o seu surgimento e ligação com o $A J C$, escrevendo sobre a comunidade judaica no Brasil no American Jewish Year Book. Ele publicou em co-autoria com Jose Isaacson, Comunidades Judias de Latino America, Buenos Aires, Comité Judío Americano Instituto de Relaciones Humanas/Candelabro, 1968, 287 pp. Cf. Tabela Comentário: Diretoria, Conselho Editorial, Secretaria de Redação e IBJCD, em Anexos, para mais detalhes.

${ }_{135}$ O AJC se mantinha informado a respeito de eventos no Brasil já em 1936 através do Dr. Ludwig Lorch de São Paulo. Entre março e agosto de 1938 foi concedido a ele pelo AJC $\$ 500$ por mês, num total de $\$ 3000$ para propósitos educacionais. Cf. o relatório "Activities of the American Jewish Committee in Latin America", 5 de novembro de 1940, The Amercan Jewish Committee, p. 5, In: www.ajcarchives.org/ajarchive/DigitalArchive.aspx, acesso em 20/12/2010. ${ }^{136}$ Horácio Lafer foi o primeiro e único membro judeu da Câmara dos Deputados por muitos anos, tendo falecido em agosto de 1965.

${ }_{137}$ The Amercian Jewish Committee Memorandum from Ralph Friedman, Chairman to Members of the Foreign Affairs Committee, Subject: summary of special activities of AJC representatives in Latin America, 22/03/1960, In: www.ajcarchives.org/ajarchive/DigitalArchive.aspx, acesso em 10/02/2010, p. 3.
} 
judeus estarem "truly interested in argentine nationalism" conforme última citação acima.

As revistas eram instrumentos dessa empreitada de dissociar dois significantes - fortemente ligados no imaginário social (comunismo e judaismo) - e atuavam para além de promover a cultura judaica e a "aproximação entre os povos". Por seus conteúdos de combate e resistência acabaram se constituindo em meios de propaganda política anticomunista. O teor cultural, o peso intelectual dos nomes que a produziam e o público universitário e acadêmico a que eram voltadas, definiam o raio de atuação no sentido de politicamente determinar/ distinguir uma cultura judaica afastando-a do comunismo. Nesse sentido, pode-se afirmar que houve um encontro de interesses por parte tanto desta liderança judaica representante de uma elite política norte-americana $(A J C)$ como do esforço anticomunista da política cultural norte-americana como um todo, de coloração conservadora construída na década de 1950. 
II - Sobre a Comentário do Brasil

2.1 - Dados técnicos, seções fixas: fontes de informações culturais

\begin{abstract}
"A análise de um periódico permite distinguir as partes que 0 compõem, preenchendo funções e atendendo objetivos que podem ser não apenas informativos, mas políticos, sociais, econômicos, educativos ou culturais. Daí a necessidade de sabermos, antes de tudo, quais os propósitos mais amplos do periódico, as concepções que o definem e regem sua redação, que grupos ou grupo social ele representa, e mesmo qual é o seu sustento econômico-financeiro.

As chamadas seções, que nos periódicos mais representativos são permanentes, servem de roteiro técnico para fins de pesquisa, pois lá encontramos "sistematizados" os temas ou as questões que visamos elucidar ou estudar em nosso trabalho científico. "Nachman Falbel, Judeus no Brasil, Estudos e Notas, São Paulo: Humanitas; Edusp, 2008, p. 46
\end{abstract}

No capítulo anterior desenvolvemos uma análise das concepções e objetivos que definem a revista Commentary fazendo, sempre que possível, um contraponto com a Comentário brasileira. Tendo como arcabouço referencial as circunstâncias políticas e culturais de surgimento e desenvolvimento daquela revista americana e sua bem-sucedida inserção tanto na comunidade judaica como na sociedade americana como um todo ${ }^{138}$, analisaremos mais pormenorizadamente Comentário começando a partir de alguns elementos básicos propostos pelo historiador Nachman Falbel ${ }^{139}$.

Produzida no Brasil entre 1960 e 1973, Comentário teve como proposta oficial reproduzida de sua matriz Commentary americana: incentivar o debate, a exposição de ideias, a crítica e a livre expressão. Dentre seus principais colaboradores, destacavam-se pensadores das mais diversas áreas do conhecimento, dedicados a refletir sobre a cultura nacional e internacional. Música, teatro, literatura, política, psicanálise, educação, história, antropologia, são alguns dos segmentos valorizados pelo grupo editorial fundador. Manteve,

\footnotetext{
${ }^{138}$ De acordo com Murray Friedman por volta de 1950, Commentary havia se tornado a principal publicação da vida intelectual e do pensamento americano. Cf. Murray Friedman, "Introduction. Comentary: The First Years", In: Murray Friedman (editor), Op. Cit., 2005, p. 3. ${ }^{139}$ Nachman Falbel, Judeus no Brasil, Estudos e Notas, São Paulo: Humanitas; Edusp, 2008, p. 46.
} 
na sua essência, o perfil de um periódico de combate e resistência ao totalitarismo em prol de uma cultura de paz e dos direitos humanos.

Convém lembrar que o nazismo, a Segunda Guerra Mundial e a Shoah suscitaram mudanças em relação ao significado de judaísmo e de povo judeu contribuindo para a construção de uma nova concepção congregacional, que passou a unir as diferenças através de entidades. Assim, foi criado em Genebra em 1936 foi criado o World Jewish Congress, representante das comunidades judaicas na Diáspora com o objetivo de uni-las e mobilizar todos os países contra a investida nazista. A ideia era promover a unidade e a sobrevivência criativa do povo judeu e manter sua herança espiritual, cultural e social $^{140}$.

No Brasil surgiram instituições identificadas com a filosofia política de evidenciar o judaísmo que unia organizações particulares, respeitando as suas diferenças. Dentre estas cumpre citar a Federação Israelita do Estado de São Paulo (Fisesp) onde o rabino alemão Fritz Pinkuss ${ }^{141}$ participou da criação de um rabinato liberal e de um ortodoxo e a Confederação Israelita do Brasil, entre outras federações estaduais ${ }^{142}$.

Segundo a periodização da história dos judeus no Brasil elaborada pelo historiador Nachman Falbel, a revista Comentário está inserida no Período Republicano, especificamente, a partir da sexta classificação "1957 até hoje" compreendendo a "nova comunidade e o ingresso de novos imigrantes vindos

\footnotetext{
${ }^{140}$ A respeito do World Jewish Congress, ver http://www.worldjewishcongress.org/aboutus.html, acesso em 3/02/2011.

${ }_{141}$ Rabino alemão que imigrou para o Brasil em 1936, radicando-se em São Paulo onde passou a oferecer orientação judaico-religiosa a judeus alemães refugiados, que começavam a se organizar na América do Sul. Seguindo os princípios do judaísmo liberal alemão, Pinkuss iniciou suas atividades na SIP (Sociedade Israelita Paulista), precursora da CIP (Congregação Israleita Paulista), participando ativamente de sua fundação em 1936. Foi rabino da congregação atuando até 1955 e rabino-mor até a sua aposentadoria em 10/03/1987, quando passou a rabino-mor emérito. Pinkuss tornou-se membro da Central Conference of American Rabbis e fez parte do World Union for Progressive Judaism. Lecionou na Universidade de São Paulo de 1945 a 1975 como titular da cadeira de hebraico do Departamento de Linguistica e Estudos Orientais, tendo proferido a aula inaugural em 28/03/1946. Foi co-fundador e diretor do Centro de Estudos Judaicos (CEJ) da Universidade de São Paulo (USP). Foi nomeado Professor Emérito da Faculdade Renascença. Recebeu os títulos de Doutor em Divindade, Honoris Causa, pelo Hebrew Union College, de Cincinnati, Estados Unidos e Honorary Fellow, na Universidade Hebraica de Jerusalém. Cf. PINKUSS, Fritz, Estudar Ensinar Ajudar: seis décadas de um rabino em dois continentes, Livraria Cultura Editora, $1^{\underline{a}}$ edição: setembro de 1989. Cf. Tabela Comentário: Diretoria, Conselho Editorial, Secretaria de Redação e IBJCD, em Anexos, para mais detalhes.

${ }^{142}$ Cf. PINKUSS, Fritz, Op. Cit., 1989, pp. 67-68.
} 
de países da América Latina e de outros lugares e sua caracterização" ${ }^{143}$. Foi a partir da década de 1950 que a comunidade se desenvolveu e se estabilizou em termos organizacionais. O rabino Fritz Pinkuss foi uma figura muito importante no processo de criação de uma congregação (kehilá) no Brasil pensada não apenas enquanto um grupo de refugiados, mas como uma comunidade caracterizada pela composição judaico-brasileira ${ }^{144}$. A maioria da comunidade judaica havia chegado no período entre as duas grandes guerras. Portanto, ainda era uma comunidade de imigrantes em termos de liderança no início dos anos de 1960. De modo que as responsabilidades comunitárias nas mãos da primeira geração nativa de imigrantes - recém-formada em cursos superiores em sua maioria - era algo muito recente ${ }^{145}$.

A relação de Fritz Pinkuss com o American Jewish Committee era "profícua" como ele mesmo definiu em suas memórias, e caracterizada pela ideia de um judaísmo independente, mas em contato com o mundo todo, tendo participado do jubileu dos 50 anos do $A J C$, em Nova lorque, em $1957^{146}$.

Segundo Maria Luiza Tucci Carneiro, os intelectuais e artistas que se refugiaram no Brasil após 1933 traduziram "o mundo cinzento da guerra", "nas décadas de 1950 e 1960, sob a forma de verdadeiras metáforas" e contribuíram, enquanto "cidadãos do mundo" para uma nova situação cultural no Brasil, que se prestou, portanto, enquanto um "refúgio da cultura"147. A revista Comentário reuniu alguns destes refugiados fortalecendo a configuração de uma nova geração de intelectuais judeus que manteve a proposta de preservar a cultura judaica. Ao identificarmos os representantes dessas gerações de intelectuais que se cruzam, assim como as suas produções, estaremos reconstituindo o perfil político-cultural da Comentário..

A direção e administração da revista Comentário estavam sediadas à Avenida Rio Branco, no Rio de Janeiro, cidade que desde o final do século XIX abriga uma importante comunidade de imigrantes judeus. Estava representada nas cidades de São Paulo, Porto Alegre, Recife, Belo Horizonte, Curitiba,

\footnotetext{
143 Ídem, p. 27.

${ }_{144}^{144}$ Cf. PINKUSS, Fritz, Op. cit., 1989, p. 49.

${ }^{145}$ Cf. Abraham Monk, "Brasil”, Foreign Coutries: Latin America, American Jewish Year Book (AJYB), Vol. 64, 1963, p. 283. In: http://www.ajcarchives.org/AJC DATA/Files/1963 8 LatAmerica.pdf, acesso em 6/04/2011. ${ }^{146}$ Idem, p. 91

${ }^{147}$ Maria Luiza Tucci Carneiro, Brasil, Um Refúgio nos Trópicos: A Trajetória dos Refugiados do Nazi-fascismo. São Paulo, Estação Liberdade, 1996, p. 165.
} 
Niterói, Belém e Salvador. Além da assinatura anual, o número avulso poderia ser adquirido em livrarias de São Paulo, Rio de Janeiro e Recife.

\section{Em 1967 e 1968, o Conselho Editorial da revista era composto pelos}

seguintes nomes: Fritz Pinkuss, [como representante da comunidade judaica paulista em termos congregacionais como rabino da Congregação Israelita Paulista (CIP), de orientação liberal]; Henrique Lemle ${ }^{148}$ [representando a comunidade carioca, como rabino da Associação Religiosa Israelita (ARI)]; Walter Griessman e Rubens Amaral ${ }^{149}$. Integravam a Comissão Editorial, A. Koogan $^{150}$, Abraham Monk, Alfred Hirschberg ${ }^{151}$, Anita Novinsky, Boris Schnaidermann ${ }^{152}$, Celso Lafer $^{153}$, Gabriel Bolaffi ${ }^{154}$, Henrique Rattner, Jacó Guinsburg $^{155}$, Marcos Magulies, Peter Schwabe e Samuel Malamud ${ }^{156}$. Seu

${ }^{148}$ Henrique Lemle, rabino cuja formação se deu nos seminários rabínicos e nas Universidades de Berlim, Breslau e Wuerzburg. Esteve no campo de concentração de Bunchenvald antes de sua vinda ao Brasil em dezembro de 1940. Exerceu o cargo de professor de civilização Hebraica na Faculdade de Filosofia da UFRJ e recebeu o título de doutor honoris causa em teologia pela Universidade Hebraica de Jerusalém. Foi líder espiritual da Associação religiosa Israelita (ARI) no Rio de Janeiro e parceiro de trabalho de Fritz Pinkuss da CIP em São Paulo. As duas eram "organizações-irmãs", segundo Pinkuss. Lemle veio ao Brasil a convite de Pinkuss e como enviado do World Union for Progressive Judaism. Ele foi o primeiro rabino liberal do Rio de Janeiro no final dos anos 1930 e um importante interlocutor, constantemente ouvido pelas autoridades do governo brasileiro durante a II Guerra. Cf. PINKUSS, Fritz, Op. cit., 1989, p. 91; Henrique Veltman, A História dos Judeus no Rio de Janeiro. Rio de Janeiro, Editora Expressão e Cultura, 1998, p. 146.

${ }^{149}$ Issac Ruben Israel, como Rubens Amaral se chamava antes de vir para o Brasil, era advogado e um jornalista de destaque, tendo trabalhado na BBC de Londres por oito anos. Casou-se com Rosa, a filha mais velha dos Barki, que no Rio de Janeiro atuavam no ramo do comércio varejista e circulavam nos "meios elegantes e sofisticados da cidade". Cf. Rachel Mizrahi, Imigrantes Judeus do Oriente Médio - São Paulo e no Rio de Janeiro, São Paulo, Ateliê Editorial, 2003, p. 73.

${ }_{151}^{150}$ Abraham Koogan, editor.

151 Judeu alemão radicado em São Paulo a partir de 1940 e um dos maiores responsáveis pela criação, administração, organização de entidades judaicas e publicações judaicas no Brasil.

${ }_{152}$ Boris Schnaidermann nasceu em Uman na Ucrânia, tendo imigrado ao Brasil aos oito anos de idade com os pais. Começou a traduzir autores russos em 1944 e a colaborar na imprensa a partir de 1957. Entre os escritores que traduziu estão: Fiódor Dostoiévsky, Anton Tchekhov e vários poetas. Schaneidermann estimulou o estudo de tradução de obras da literatura russa. Não fez formação acadêmica na área de Letras, porém foi o precursor do curso de Língua e Literatura Russa da Universidade de São Paulo onde obteve o título de Doutor e Livre-docente. ${ }^{153}$ Quando começou a escrever na revista tinha 21 anos e era estudante da Faculdade de Direito e da Faculdade de Filosofia, Ciências e Letras da Universidade de São Paulo. Havia obtido o Prêmio Gastão Vidigal de 1960 destinado ao melhor aluno de Economia Política da F.D. Era redator da revista Onze de Agôsto e Diretor Cultural do centro acadêmico que levava o mesmo nome da revista. Cf. "Notas para um estudo do judeu em Gil Vicente", In: Comentário, Ano III, n. 1, 1962, p. 73.

${ }^{154}$ Sociólogo formado pela Universidade de São Paulo. Escreveu artigos para o suplemento literário de O Estado de São Paulo e para a revista Anhembi.

155 Jacó Guinsburg passa a fazer parte do corpo editorial da revista a partir do segundo trimestre de 1962 quando é criada a Comissão Consultiva de São Paulo que reunia ainda Alfred Hirschberg, Marcos Margulis, Fritz Pinkuss, Anatol Rosenfeld e Boris Schneiderman. No trimestre seguinte, essa comissão passa a se chamar Comissão Editorial de São Paulo. 
diretor foi de 1960-1971 o advogado e escritor Joseph Eskenazi Pernidji ${ }^{157}$, um dos contatos oficiais com o $A J C^{158}$.

A revista Comentário foi um produto do Instituto Brasileiro e Judaico de Cultura e Divulgação, uma sociedade civil fundada em 29 de novembro de 1956, sediada na cidade do Rio de Janeiro cujos fins são descritos em seu Estatuto como “(...) culturais e científicos, visando à divulgação de valores espirituais brasileiros e judaicos." Havia uma anuidade paga pelos sócios fundadores, efetivos e benfeitores que integrava o capital da sociedade. Os principais objetivos constantes no Estatuto foram assim definidos:

a) estimular a publicação de obras culturais e científicas, instituindo concursos;

b) organizar biblioteca, a ser franqueada a todos os estudiosos; c) publicar livros, revistas, separatas, monografias, de interesse cultural;

d) desenvolver intercâmbio cultural com instituições congêneres e Academias de Letras. ${ }^{159}$

Junto à diretoria do Instituto Brasileiro e Judaico de Cultura e Divulgação constavam os nomes de Isaac Albagli (1960-1961) e Joseph Eskenazi Pernidji (1962-como Presidente e de José Mindlin ${ }^{160}$ e Peter Schwabe como $1^{\circ}$ e $2^{\circ}$ vice-presidente, respectivamente ${ }^{161}$. Abraham Monk, Alfred Hirschberg e Marcos Magulies colaboraram entre 1960 e 1973 fornecendo o texto das informações a respeito da presença e posicionamento da comunidade judaica no Brasil associada à situação política, econômica e social brasileira para o American Jewish Year Book, publicado todos os anos pelo AJC e The Jewish

\footnotetext{
${ }^{156}$ Cf. dois números da revista. Cf. In: Comentário nos 1 (29) e 2 (34), Ano VIII, vol. 8 e ANO IX, vol. 9, $1^{\circ}$ trimestre e $2^{\circ}$ trimestre, 1967 e 1968 , respectivamernte.

${ }^{157} \mathrm{O}$ advogado carioca Joseph Eskenazi Pernidji (1920-2007) atuava na área de Direito Internacional e era um estudioso da história dos judeus e cristãos-novos da Península Ibérica.

${ }_{158}$ Mais detalhes sobre todos aqueles que ocuparam cargos na revista ver Tabela Comentário: Diretoria, Conselho Editorial, Secretaria de Redação e IBJCD, em Anexos.

${ }_{159}$ Ver Estatutos do Instituto Brasileiro e Judaico de Cultura e Divulgação, p. 1, Caixa 61, Instituto Brasileiro e Judaico de Cultura e Divulgação, Fundo Dr. Alfred Hirschberg, AHJB. 160 José Mindlin, advogado, foi presidente da CIP. Cf. PINKUSS, Fritz, Op. cit. 1989, p. 62.

${ }^{161}$ No início de 1950 o representante do Departamento da América Latina realizou conferências com líderes de vários grupos judaicos no Brasil em preparação para o estabelecimento do Instituto similar ao Instituto Judaico Argentino. Esperava-se que ele começasse a funcionar em 1951. Ver: Israel/AJC Israel Office File, Foreign Affairs Department Collection, FAD-1.

Memoranda from William Frankel to Foreign Affairs Department on the question of establishing an office in Israel, 1947-1957, 14 de março de 1947, In: www.ajcarchives.org/ajarchive/DigitalArchive.aspx, acesso em 20/12/2010, p. 11.
} 
Publication Society of América, nos Estados Unidos, e pela American BookStratford Press, Inc., New York. ${ }^{162}$

Alfred Hirshberg atuou junto ao AJC desde a década de 1940, escrevendo inclusive para a revista que antecedeu Comentário, a já citada Contemporary Jewish Record (CJR), a respeito, por exemplo, de Direitos Humanos. ${ }^{163}$ De São Paulo Hirschberg viajava aos Estados Unidos e freqüentava reuniões do Foreign Affairs Committee (Comitê para assuntos estrangeiros) do $A J C$ levando as informações sobre a comunidade judaica no Brasil que junto com a da Argentina eram tidas como, ainda hoje, as maiores da America Latina.

Em reunião de abril de 1959, Hirschberg, que colaborava com o Instituto Brasileiro e Judaico de Cultura e Divulgação e era Diretor executivo da CIP, tratou da história da comunidade judaica no Brasil afirmando que a imigração considerável para o país começara em meados de 1920 e que até muito próximo daquele momento a vida judaica estava modelada segundo a fragmentada paisagem do Velho Mundo, sem cooperação entre os diferentes grupos. Segundo Hirschberg, uma certa união tivera início na última década, primeiro com a ajuda ao Estado de Israel, através da federação das organizações judaicas que foram se desenvolvendo no âmbito das atividades judaicas. Ainda, naquele momento, ou seja, no final da década de 1950, começava a participação gradual da segunda geração nas atividades judaicas, e as divisões de grupos judaicos (Alfred Hirschberg não esclarece a natureza dessas divisões, mas supomos tratar-se das divisões políticas) estavam se tornando muito menos marcadas.

A impressão de Hirschberg, entretanto, era de que apesar do espírito liberal do povo brasileiro, ainda havia pouco contato entre judeus e não-judeus. Mesmo sem tais contatos os jovens judeus estariam rapidamente se assimilando ao ambiente, e uma vez que os brasileiros, embora católicos, eram largamente desinteressados em religião, a nova geração judaica estava

\footnotetext{
${ }^{162}$ Esse material pode ser consultado através do site do www.ajcarchives.org., acessado para esta pesquisa em 8/4/2008.

${ }^{163}$ Cf. Alfred Hirschberg, Human Rights or Minority Rights, CJR, contents for February 1945, pp. 43-47, Jews \& Judaism/ File, AJC Subject Files Collection. Memoranda and reports on American Jewry. Included a report on the American Council for Judaism, 1945-1947. (4), In: www.ajcarchives.org/ajarchive/DigitalArchive.aspx, acesso em 01/03/2011.
} 
também progressivamente perdendo o interesse pelo judaísmo. A principal tarefa da comunidade judaica organizada seria, portanto, dar conteúdo judaico à vida dos jovens, para que eles se mantivessem judeus concomitantemente à sua integração na sociedade brasileira. Os jovens judeus pareciam estar cada vez mais interessados na vida pública do Brasil, país onde considerariam um futuro, de acordo com a avaliação de Hirschberg. Nesse sentido, a expectativa era de otimismo, uma vez que, no final de 1959, a tendência era de desenvolvimento o que podia favorecer o rompimento com a velha estrutura partidária e o envolvimento com o processo de democratização da vida política. Assim, "jovens judeus dotados" podiam esperar melhores oportunidades para participar na vida do país.

Não havia antissemitismo explícito no Brasil naquele momento, segundo Hirschberg e, dentro de certos limites, as portas estavam abertas para a imigração de judeus. Desde 1958 até aquela data cerca de 5000 judeus teriam sido admitidos para receber visto para entrar no Brasil sendo a maior parte, húngaros e egípcios. Essa avaliação foi apresentada durante a 52ª . Reunião Anual do $A J C$ aos membros do AJC, ao pessoal do Foreign Affairs Committee (Comitê de Assuntos Externos ou estrangeiros) e da Committee on Israel (Comissão sobre Israel) além de convidados, entre os quais estava Hirschberg ${ }^{164}$.

Esse discurso de Hirschberg explica o projeto da inserção da revista no meio universitário, conforme ainda o perfil claramente acadêmico de seus colaboradores. O escritório do AJC ajudou o Instituto Judeu Brasileiro no lançamento da versão brasileira de Comentário. Primeiramente, se estabeleceu um contato com o Grupo Universitário Hebraico, uma organização de aproximadamente 250 estudantes universitários no Rio de Janeiro (de um total de 600 estudantes judeus nas três universidades da cidade), no sentido de cooperar na distribuição da revista Comentário. Esperava-se ampliar essa área da atuação com os estudantes. No oitavo ano de existência da revista, em

\footnotetext{
${ }^{164}$ Minutes of Joint Meeting of Foreign Affairs Committee and Committee on Israel Commodore Hotel, 17/04/1959 (AJC 52 $2^{\text {nd }}$ Annual Meeting, Jews \& Judaism/ File, AJC Subject Fille Collection. Memoranda and reports on American Jewry. (4), In: www.ajcarchives.org/ajarchive/DigitalArchive.aspx, acesso em 01/03/2011, pp. 1-3.
} 
1967, esse grupo contava com 2.500 membros com ramos na Bahia, Belo Horizonte, Guanabara, São Paulo e Porto Alegre ${ }^{165}$.

Havia um esforço no sentido de que a juventude judaica se envolvesse com os assuntos judaicos. Assim em 1964/1965 Gabriel Bolaffi e Henrique Rattner da Universidade de São Paulo, ambos atuantes na revista, conduziram uma pesquisa sociológica a respeito da atitude dos estudantes universitários em relação ao judaísmo. Essa pesquisa foi distribuída entre organizações judaicas e líderes comunitários no Rio de Janeiro e em São Paulo. Ao mesmo tempo uma reunião no Rio de Janeiro foi convocada pela ARI e o IBJCD para se discutir a pesquisa com os autores ${ }^{166}$.

A revista foi distribuída aos líderes em educação e religião; aos profissionais de diferentes áreas, incluindo aqueles do campo das artes, ao governo e aos oficiais da Embaixada Americana no Brasil, além de oficiais brasileiros nos Estados Unidos. De acordo com Ralph Friedman, presidente da Comissão de Assuntos Externos do $A J C$, a publicação foi amplamente aclamada e os Comentários da imprensa teriam sido favoráveis como um todo. ${ }^{167}$

Promovendo a cultura judaica, a publicação procurava não enfrentar as classes dirigentes. Ao contrário, conforme já destacamos, o objetivo era de estreitar laços e associar interesses por parte da $A J C$ de onde partiam as diretrizes e os rumos previstos para a revista. Tudo indica que a grande parte dos intelectuais da comunidade judaica representados em Comentário, se viu atuando no sentido de defender a preservação da cultura judaica através dos chamados estudos judaicos e combater o antissemitismo. Procuravam manterse desvinculados de qualquer partido político, investidos de um objetivo "maior": o debate intelectual cultivado enquanto defensores do diálogo para a paz através da aproximação entre os povos.

\footnotetext{
${ }^{165}$ Cf. Alfred Hirschberg "Brasil", Foreign Coutries: Latin America, American Jewish Year Book (AJYB), Vol. 69, 1968, p. 412. In: http://www.ajcarchives.org/AJC DATA/Files/1968 9 LatAmerica.pdf, acesso em 17/04/2011. ${ }^{166}$ Cf. Cf. Alfred Hirschberg "Brasil", Foreign Coutries: Latin America, American Jewish Year Book (AJYB), Vol. 67, 1966, p. 300. In: http://www.ajcarchives.org/AJC DATA/Files/1962 16 LatinAmerica.pdf, acesso em 14/04/2011.

${ }^{167}$ Cf. The Amercian Jewish Committee Memorandum from Ralph Friedman, Chairman to Members of the Foreign Affairs Committee, Subject: summary of special activities of AJC representatives in Latin America, 22/03/1960, In: www.ajcarchives.org/ajarchive/DigitalArchive.aspx, acesso em 10/02/2010, p. 3.
} 
Diversos intelectuais não-judeus representativos da elite intelectual brasileira colaboraram com revista Comentário. Entre alguns dos colaboradores da revista nacionais e internacionais - identificados a partir de artigos reproduzidos das revistas argentina e norte-americana - citamos Gershom Scholem, proeminente intelectual judeu, professor de misticismo judaico da Universidade Hebraica de Jerusalém e um dos representantes das matrizes teóricas da revista; Marcos Almir Madeira, professor de Sociologia da Universidade do Brasil, Fundação Getúlio Vargas, e Escola do Estado-Maior Exército, membro da Academia Fluminense de Letras e um dos diretores do Suplemento Literário de O Fluminense, publicado em Niterói; Claribalte Passos, compositor, sócio-fundador-proprietário da Orquestra Sinfônica Brasileira; José Arthur Rios, sociólogo, professor da Pontifícia Universidade Católica, presidente do Instituto de Estudos para o Desenvolvimento Social Contemporâneo; o escritor José J. Veiga; Moysés Blaumstein, artista plástico, desenhista e formado pela Escola de Arte Dramática; Luís Washington Vita, secretário do Instituto Brasileiro de Filosofia, professor da Escola de Sociologia e Política da cidade de São Paulo; Kurt Grossman, jornalista e escritor; Mauro Ribeiro Viegas, catedrático da Faculdade de Arquitetura e Urbanismo da Universidade Federal do Rio de Janeiro; Mário Barata, professor catedrático de História da Arte e Estética da Universidade Federal do Rio de Janeiro; Richard Marienstras, jornalista francês; Maurice Goldbloom, jornalista americano; Leo Strauss, professor de Ciência Política da Universidade de Chicago, estudioso do helenismo e do judaísmo; Arthur Hertzberg, rabino e professor de História da Columbia University; Maria Tereza Camargo Biderman, professora-regente de Lingüística Românica na Faculdade de Filosofia, Ciências e Letras de Marília; Moisés Gicovate, advogado, geógrafo e escritor; somente para citar alguns nomes ${ }^{168}$.

Tratava-se de um grupo heterogêneo, multidisciplinar, cujo perfil reforçava a proposta da publicação - trimestral no caso brasileiro - de defender a aproximação cultural, integração social e, sobretudo, oferecer um espaço para se pensar a cultura, favorecendo a elaboração intelectual da cultura

\footnotetext{
${ }^{168}$ Esse nomes foram levantados a partir de dois números da revista, somente a título de amostragem. Cf. In: Comentário nos. 1 (29) e 2 (34), ANO VIII, vol. 8 e ANO IX, vol. 9, $1^{\circ}$ trimestre e $2^{\circ}$ trimestre, 1967 e 1968 , respectivamernte.
} 
nacional e internacional. Entendemos que o grupo - enquanto representante de uma elite intelectual - buscava valorizar questões ligadas propriamente ao judaísmo e a aspectos da cultura nacional pressupondo a preservação da identidade judaica e sua inserção/participação na realidade social e política brasileira em detrimento de um partidarismo político. Mas não sem atuar politicamente, conforme já expusemos no primeiro capítulo ao tratarmos da atuação do $A J C$, embora julguemos que as diretrizes do $A J C$ fossem conhecidas apenas por alguns nomes ligados aos cargos de diretoria da revista. Importante frisar que a liberdade editorial foi amplamente citada pelos entrevistados e era como sendo muito importante para os colaboradores, principalmente os judeus cientes e críticos das perseguições e censuras sofridas pelos intelectuais judeus na União Soviética. Da mesma forma os intelectuais brasileiros de esquerda não aceitariam ter seus materiais censurados. Comentário publicava artigos reproduzidos da revista americana que frisavam a falta de liberdade para escrever na União Soviética. A liberdade editorial completa pregada pela revista se opunha a esse amordaçamento a cultura $^{169}$.

A seção "Cartas à Redação" permite a identificação do leitor que se interessava pela revista e, principalmente, quem a recebeu gratuitamente a título de divulgação enquanto público-alvo da direção do periódico nos primeiros anos da revista. Esta seção foi excluída da revista em 1962 retornando em 1965 sob o nome de somente "Cartas" e como último item. As cartas procediam de diferentes direções do Brasil informando sobre a circulação em nível nacional (Bahia, Pernambuco, Paraná, Paraíba, Rio Grande do Norte, Ceará, São Paulo e Rio de Janeiro) e internacional (Buenos Aires/Argentina, Santa Fé/Argentina, Estados Unidos, República Democrática Alemã).

Em 1960, no segundo número, a escritora Cecília Meireles recomendou a revista enquanto um veículo de diálogo entre judeus e não-judeus, manifestando apoio à criação do Estado de Israel. O Presidente da Associação Brasileira de Imprensa ( $\mathrm{ABI}$ ) também saudou o aparecimento da publicação seguido pelo educador e sociólogo Fernando de Azevedo da Universidade de

\footnotetext{
${ }^{169}$ Ver o artigo de Theodore Frankel, "Arte, Política - liberdade soviética", In: Comentário, Ano VIII, n. 1, 1967, pp. 5-16.
} 
São Paulo (USP), por Levi Carneiro da Academia Brasileira de Letras (ABL) que agradeceu o recebimento da revista ${ }^{170}$, o mesmo fazendo o então deputado Carlos Lacerda, a feminista Carmem Portinho, engenheira responsável pela construção do Museu de Arte Moderna (MAM) do Rio de Janeiro. O educador e primeiro dirigente da Campanha (hoje Coordenação) Nacional de Aperfeiçoamento do Pessoal de Nível Superior (CAPES), Anísio S. Teixeira, que escrevera um artigo sobre a Lei de Diretrizes e Bases no primeiro número da revista, também ofereceu os seus cumprimentos pela publicação e o Prof. Dr. Silveira Bueno da Faculdade de Filosofia, Letras e Ciências Sociais (FFLCH), USP a considerou um dos bons presentes que recebera no ano de $1960^{171}$. No quarto número da revista destacamos os elogios à revista e agradecimento pela remessa por parte de Cândido de Oliveira Neto, Procurador Geral da Justiça do Estado da Guanabara; Lourdes S. Bastos em nome de Niomar Moniz Sodré do Museu de Arte Moderna do Rio de Janeiro e Guilherme Estelita C. de Albuquerque, desembargador. Em 1961 a expressão de admiração pela revista sobrevém de Ivar Feijó dos Diários Associados, do deputado J. Barros de Morais, Prof. Dr. J. Angely, Diretor do Instituto Paranaense de Botânica e E. D. Moniz de Aragão, Prof. Catedrático da Faculdade de Direito do Paraná. Jeanne Berrance de Castro, docente da Faculdade de Filosofia, Ciências e Letras de Rio Claro enviou uma carta informativa a respeito da abordagem que vinha fazendo em seus cursos de História Geral e do Brasil a respeito do "problema judaico". Em 1967 (n. 2), o Serviço de Documentação Jurídica solicitou um exemplar da revista para a Bilbioteca do Ministério Público de São Paulo.

Receberam a revista, portanto, eméritos professores da USP e de outras importantes universidades ${ }^{172}$, escritores consagrados, presidentes de Centros de Estudos, Bibliotecas, políticos, juristas e líderes que representavam a cultura nacional brasileira em seus mais diversos setores. Além deles, destacase como público-alvo a juventude israelita que no terceiro número da revista se

\footnotetext{
${ }^{170}$ Levi Carneiro, jurisconsulto, presidiu a Comissão Brasileira da UNESCO, representando o Brasil ainda na Comissão de Conciliação com os Estados Unidos, na Comissão de Conciliação e Inquérito das Nações Unidas, na Côrte Permanente de Arbitragem de Haia e na Côrte Internacional de Justiça. Escreveu na revista o artigo "Stefan Zweig - no vigésimo aniversário de sua morte", In: Comentário, Ano III, n. 2, 1962, pp. 138-143.

171 Comentário no 2 , ANO I, $2^{\circ}$ trimestre, 1960, p. 4.

${ }^{172}$ Comentário no 1 , ANO II, Vol. 2, 1ำ trimestre, 1961, p. 6.
} 
manifesta por meio de Alexandre Goehler, presidente do Grêmio da Juventude da Congregação Israelita Paulista (CIP), aparecendo outros de seus portavozes ao longo dos anos e em diferentes regiões do país. Para Goehler, Comentário, preencheria uma "grande lacuna de cultura judaica brasileira" e seria de importante leitura para os jovens judeus ${ }^{173}$. Merece destaque ainda a liderança religiosa católica como Dom Manuel da Silveira D’Elboux, Arcebispo de Curitiba ${ }^{174}$ e P. Estevão Bettencourt, OSB do Mosteiro de São Bento no Rio de Janeiro ${ }^{175}$, além do Padre Eduardo Hoornaert, bibliotecário do Seminário Regional do Nordeste que solicitou assinatura de Comentário em 1966, n. 1, com outros casos similares em outros anos. Em 1965 a seção "cartas" apresenta os elogios à revista vindos de Salvador e João Pessoa como um elevado padrão de leitura para a juventude, público-alvo da revista, sobretudo a juventude judaica ${ }^{176}$.

Internacionalmente conhecida e respeitada, a revista foi entusiasticamente recebida pelo Prof. Edgardo Antonio Vigo, como editor, diretor e fundador da revista Diagonal Cero (1962-1968) de Buenos Aires. Vigo, artista visual, poeta e editor manifestou interesse pela xilografia contemporânea brasileira e israelense, solicitando que Comentário promovesse tal intercâmbio que realmente aconteceu. A partir deste momento, a redação da revista brasileira passou a receber em sua biblioteca a revista argentina ${ }^{177}$. Infelizmente não conseguimos nenhuma informação com os nossos entrevistados a respeito do paradeiro desta riquíssima biblioteca ${ }^{178}$.

A revista foi também elogiada e foi solicitada a remessa regular de alguns exemplares para distribuição e estudo entre os alunos e instrutores da escola de comando e Estado-Maior do Exército (ECEME) em carta assinada por Cauby Eduardo Maia Tenente Coronel e Oficial de Relações Públicas da ECEME. Este pedido demarca pela primeira vez nas cartas publicadas (1966, n. 2) um interesse por parte do Exército por tal publicação.

\footnotetext{
${ }_{174}^{173}$ Comentário oㅜ 3, ANO I, 3o trimestre, 1960, p. 4.

${ }^{174}$ Comentário ํo 1 , ANO II, Vol. 2, 1ำ trimestre, 1961, p. 6.

${ }^{175}$ Comentário no ${ }^{\circ}$, ANO I, Vol. IV, 4ํo trimestre, 1960, p. 6.

${ }_{176}$ Comentário no 1, ANO VI, 1965, p. 95.

${ }^{177}$ Comentário no 1 (21), ANO VI, Vol. 6, $1^{\circ}$ trimestre, 1965, p. 95 e n. 4, ANO I, 4ํ. Trimestre, 1960 , p. 90.

178 Tudo indica que ficou com o Diretor da revista que a doou, pois não está mais com a sua viúva, a Sra. Pernidji, que nada sabe a respeito.
} 
Pode-se ter conhecimento do conteúdo desta coleção, que é composta de livros, revistas e publicações avulsas, por meio de "Publicações Recebidas", seção criada a partir do último número da revista do ano de 1960 e "Recebemos e Agradecemos" criada em 1964 ${ }^{179}$. Eram também enviados livros $^{180}$ e revistas ${ }^{181}$.

Para Nachman Falbel, o anúncio comercial de um periódico fornece elementos "para uma história econômica da comunidade retratando as etapas e profissões desse desenvolvimento"182. Pode-se apreender pelos nomes comerciais que muitos pertenciam às famílias dos colaboradores da revista que aproveitavam o espaço para anunciar seus empreendimentos ${ }^{183}$. Alguns

179 Comentário dos anos de 1960, 1961 e 1965-1970, seções "Publicações Recebidas" e "Recebemos e Agradecemos".

${ }^{180}$ De autores como Manuel Diégues Júnior, Jarbas Maranhão, Florestan Fernandes, M. Rodrigues Lapa, Prado Kelly, Jacó Guinsburg, Herbert Caro, J. Roberto Moreira, Cecília Meireles, Queiroz Junior, Fernando Levisky, Joaquim Faria Góis Filho, Louis Jacobs, Edmond Fleg, Miguel Saidel, Anatol Rosenfeld, Irwin Edman, Stefan Baciu, Sátilas do Amaral Camargo, Emílio Willems, José Guaíba, Donald Pierson, Immanuel Velikovsky, Wladimir Lindemberg, Francis Bret Harte, Ruth Moore, Bruno de solages, Georges Bernanos, Vilem Flusser, Mário Palmério, João Guimarães Rosa, Levi Carneiro, Otto Zierer, Celso Láfer, Natália Nunes, J. Duarte, Sydnei Hook, Nelson Werneck Sodré, Carlos Heitor Cony, Jorge Amado, entre outros. ${ }^{181}$ Como Diagonal Cero, La Plata; Poesia de Venezuela, Caracas; Eco Contemporaneo, Buenos Aires; Piumo 2, Buenos Aires; Vertice, Caracas; Sintese, Guanabara; Siglo 1-Poesía, Mexico; Aqui Poesia, Montevideo; Boletín de Poesía, Buenos Aires; Inter-American Review of Bibliography, União Pana americana, Washington; Caracola, Málaga; Cadernos Brasileiros, Guanabara; Panoramas, Mexico; Alcor, Assunção; Boletín de Poesía, Buenos Aires; Commentary, Nova lorque; Horizontes, Mexico, El Correo, Paris, da UNESCO, Symposium, Pernambuco; Academus, São Paulo; Davar, Buenos Aires, Bolletino Ufficiale do Instituti e Corsi Integrati Della Fondazionne Latino America Pro Deo, Roma, Boletim do Centro LatinoAmericano de Pesquisas em Ciências Sociais, Rio de Janeiro, Síntese, Vozes, Boletim bibliográfico da UFMG, América Latina, Alcor, Juventude Renovadora, São Paulo; America Latina, Rio; Panoramas, México, Paz-Ahora, Buenos Aires; entre outras

${ }^{182}$ Nachman Falbel, Op. Cit., 2008, p. 46.

${ }^{183}$ Os anúncios eram da Sociedade Irmãos Albagli Ltda, sediados no Rio de Janeiro e que trabalhavam com importação e exportação; Parkton roupas; no Rio de Janeiro; a Importadora Helio Barki S. A., Rio de Janeiro; Barki roupas; Livraria Editora Guanabara Koogan S. A.; Comércio e Indústria de Metais "Arpa" S. A., Rio de Janeiro; Quartzolit Indústria e Comércio, Rio de Janeiro; Gethal S. A. Indústria de madeira compensada, Porto Alegre; Panauto S. A. (anúncio da motoneta Vespa), Rio de Janeiro; Banco Comercial do Estado de São Paulo S. A.; Promeca S. A. Indústria e Comércio, São Paulo; Transcontinental, empresa aérea; Restaurante Panorâmico Mesbla, Rio de Janeiro; Indústrias Móveis Guelmann S/A, Curitiba; Formiplac, Companhia química industrial de laminados, Rio de Janeiro; Neotron Comércio e Indústria Ltda., São Paulo; Produtos químicos Kauri Ltda., Rio de Janeiro; Sondotécnica Engenharia de Solos S.A., Rio de Janeiro; KLM, Royal Dutch Airlines; Formiplac, Companhia química industrial de laminados, Rio de Janeiro; IKA, fábrica de malas e artigos de viagem, Curitiba; Brasil-

Holanda de Indústria S. A. Madeiras Compensadas, Rio de Janeiro; Motoking, Rio de Janeiro, Panambra, ferramentas de corte e aparelhos científicos para laboratórios ensino e pesquisas, (São Paulo, Porto Alegre Rio de Janeiro, Belo Horizonte, Salvador, Curitiba, Blumenau e Recife); Suissair, (São Paulo, Rio e Porto Alegre), Editôra Delta S. A., Rio de Janeiro, Cavalcanti, Junqueira S. A. engenharia, (São Paulo, Brasília, Assunción - Paraguai, ), Tapeçaria Líder, Rio de Janeiro, Pan Americana - tubos e acessórios para Indústrias e Construções, Rio e São Paulo, Indústria de Papel Leon Feffer S.A., São Paulo e Rio; Severo e 
profissionais liberais anunciavam os seus serviços como no caso do engenheiro civil José Mizrahy, presente no quarto número da revista de 1960 e no terceiro número da revista do ano de 1961. Além da ajuda financeira do $A J C$ podemos atribuir a estes anúncios e aos valores das assinaturas da revista 0 seu financiamento. Também é possível constatar que a essa altura - a partir da década de 1960 - os membros da comunidade haviam se estabelecido ultrapassando os pequenos negócios e atingindo o patamar industrial no Brasil em cidades como Rio de Janeiro, São Paulo, Porto Alegre, Curitiba.

Algumas das seções fixas ou regulares de Comentário foram nomeadas de "No Prelo", englobando amostras de obras que estavam para ser publicadas, demarcando uma forte característica literária da revista; "Sôbolos do Rio que vão...", onde eram publicadas páginas antigas de conteúdo filosófico, religioso e cultural judaico, de modo a promover um resgate, valorização e divulgação de nomes consagrados da literatura hebraica e iídiche e dos filósofos e comentadores da Escritura. Havia também a seção "Registro", anotando e comentando acontecimentos da época, transcrevendo trechos de livros ou jornais, abrindo um espaço de caráter mais noticioso na revista. Em "Bibliografia", noticiavam-se os lançamentos nacionais e estrangeiros são comentados por "estudiosos de reconhecida autoridade". Ao longo dos anos essas seções sofreram algumas alterações.

Em "No Prelo" encontramos a reprodução de um capítulo do romance $O$ Canhão e a Foice, do escritor e naquele momento (1960) adido cultural de Israel no Brasil, Phinn E. Lapide ${ }^{184}$, cuja tradução brasileira seria lançada antes da versão original em inglês ${ }^{185}$, um capítulo da versão modificada de $O$ Galo de

\footnotetext{
Villares, (Bras'lia, Belo Horizonte, São Paulo e Rio de Janeiro); Manufactura de brinquedos estrela, São Paulo; Cartão Interlar; R. Simon joalheria, São Paulo; Elgin, máquina de costura; Sociedade Comercial e Importadora Hermes, S. A., Rio de Janeiro; Santos BahdurIncorporação e vendas de imóveis Itda;Predial Waisman S. A. - construção e incorporação de imóveis, Rio de Janeiro; Letras de Câmbio Credibrás, Rio de Janeiro e São Paulo; Válvula $D E C A$, São Paulo; Brasimet, comércio e indústria, S.A., São Paulo; Adonis, comércio de roupas, Rio de Janeiro; Tapêtes Tabacow, São Paulo; Leme Palace Hotel e Othon Palace Hotel, Rio de Janeiro e São Paulo, respectivamente; Xerox, São Paulo; FRANKI, tanques para combustíveis, galerias de águas e esgotos, Rio de Janeiro e outras cidades; Frigidaire, GM; entre outros. Ver em In: Comentário (1960-1966).

${ }^{184}$ Ver Comentário: Autores Internacionais, em Anexos, para mais detalhes sobre o autor.

185 ."O Canhão e a Foice", trecho, In: Comentário, 1960, n 1, ano I, Seção "No prelo", pp. 67-72. O artigo contém uma ilustração de Cândido Portinari idealizada especialmente para a revista (Ver ilustração 2 neste trabalho).
} 
Ouro, romance de Raquel de Queiroz ${ }^{186}$, o segundo ato da peça $O$ Tesouro de Chica da Silva de Antônio Callado ${ }^{187}$ e trechos da obra de fôlego de Otto Maria Carpeaux, História da Literatura Ocidental ${ }^{188}$.

Em "Sôbolos do Rio que vão..." 189 destacamos os trechos da autobiografia do consagrado escritor e humorista russo Sholem Aleichem ${ }^{190}$, o Comentário da Escritura de Malbim, rabino do Leste Europeu que produziu diversos trabalhos literários, entre eles um Comentário minucioso da Bíblia ${ }^{191}$, trecho da autobiografia de Theodor Herz ${ }^{192}$ e o conto do escritor em língua iídiche Itzchak Leib Perez ${ }^{193}$. A importância da língua e literatura iídiche, antes tão comum a milhões de judeus askenazim se ampliava na medida em que se percebia o desaparecimento das últimas gerações da Europa Oriental.

Em "Registro" foi citada a concessão do "Prêmio Moinho Santista" outorgado ao escritor Alceu Amoroso Lima, fato que suscitou uma breve análise de sua personalidade e obra, redigida por Gladstone Chaves de Melo, vereador na época e companheiro chegado daquele escritor católico e homem público que revia seus posicionamentos conservadores desde a década de 1940. Em 1961 o governo do então Estado da Guanabara atribuiu à uma escola primária do Rio de Janeiro o nome de Anne Frank, o que mereceu ser noticiado na seção junto com uma crônica de Valfrido Piloto. Importante ressaltar que, somente a partir da década de 1960, é que começou a ser rompido o silêncio que até então pairava sobre a história e memória do Holocausto. A historiografia brasileira precisaria ainda de mais alguns anos para se interessar pelo tema enquanto objeto de investigação.

A Seção "Bilbiografia" revela mais do perfil da revista que escolhia criticar publicações nacionais acadêmicas e literárias (envolviam os temas da

\footnotetext{
186 .O Galo de Ouro", trecho, In: Comentário, 1960, n 2, ano I, Seção “No prelo”, pp. 83-86.

187 "O Tesouro de Chica da Silva", Segundo ato, inédita, In: Comentário, 1961, n 3, ano II, Seção "No prelo", pp. 258-274.

188 "Uma História da Literatura Ocidental", In: Comentário, 1961, n. 4, ano II, "Seção No Prelo", pp. 364-366.

${ }_{189}$ Ver tabela específica com breves biografias dos autores dos textos publicados nessa seção em Anexos.

${ }^{190}$ Sholem Aleichem, "Como me tornei escritor - Contribuição para minha biografia", In: Comentário, revista trimestral, Ano I, ํo. 1, janeiro, fevereiro e março de 1960, pp. 73-76. Em 1966 a revista publicou de Elias Schulman, "Sholem Aleichem", In: Comentário, Ano VIII, n. 1, 1967, pp. 78-82, onde o autor de Jewish Education in the Soviet Union trata a respeito de um dos mestre daquela literatura.

${ }_{191}$ Malbim, "O Amor ao Próximo", In: Comentário, Ano I, no. 1, 1960, pp. 77-78.

192 Theodor Herzl "Autobiografia”, In: Comentário, Ano I, no. 4, 1960, pp. 68-70.

${ }^{193}$ Itzchak Leib Perez “'Neila' no Inferno", In: Comentário, Ano I, no. 4, 1960, pp. 71-74.
} 
imigração, racismo, as publicações do AJC, tais como o American Jewish Year Book, as primeiras obras artísticas a respeito do holocausto que começavam a surgir quinze anos depois da tragédia, romances nacionais, obras que envolviam temas da cultura como o folclore, dentre outros); além das publicações cujos Comentários eram diretamente reproduzidos da COMENTARIO argentina e de Commentary (envolvendo trabalhos sobre o panorama árabe, o nazismo, Israel, Holocausto e darwinismo). Havia ainda críticas como as contra obras de conteúdo antissemita publicadas ainda naqueles tempos como a de Pio Benedito Ottoni, A Inquisição (1960), que recuperava as acusações medievais de assassinatos rituais promovidos por judeus entre outras colocações preconceituosas ${ }^{194}$.

Em 1964, a revista Comentário foi reconhecida pelo Conselho Nacional para a Cultura como uma das principais publicações culturais. Registraram-se 125 assinaturas para a distribuição em 16 locais diferentes no norte do Brasil, visitados por uma caravana de cultura que aquele Conselho organizou ${ }^{195}$. No mesmo ano, cem cópias da revista Comentário foram distribuídas em escolas secundárias de São Paulo financiadas pela iniciativa do deputado estadual Zveibil, então diretor da Caixa Econômica Federal em São Paulo ${ }^{196}$.

Em 1969, portanto no seu décimo ano de existência, a partir do primeiro número, Comentário passou por uma série de modificações editoriais no formato e apresentação, enriquecida com ilustrações acompanhando os textos e a introdução de novos cargos como o de diagramador. A composição e impressão da revista começaram a ser realizadas em São Paulo. Fotografias dos autores foram adicionadas aparecendo ao lado de uma breve referência biográfica, demarcando uma tendência até hoje presente em revistas que comentam política, economia e cultura de inspiração nas publicações do mesmo gênero norte-americanas. O número de anúncios também aumentou, explicitando a ampliação do raio de circulação do periódico.

\footnotetext{
${ }^{194}$ Ver crítica de Ernst Fromm, "A Inquisição Reabilitada”, In: Comentário oㅜ 1, ANO II, 1ำ trimestre, 1961, p. 95.

${ }^{195}$ Cf. Alfred Hirschberg, "Brasil", Foreign Coutries: Latin America, American Jewish Year Book (AJYB), Vol. 65, 1964, p. 190. In: http://www.ajcarchives.org/AJC DATA/Files/1964 7 LatAmerica.pdf, acesso em 6/04/2011. ${ }^{196}$ Cf. Alfred Hirschberg, "Brasil", Foreign Coutries: Latin America, American Jewish Year Book (AJYB), Vol. 66, 1965, p. 348. In: http://www.ajcarchives.org/AJC DATA/Files/1965 8 LatAmerica.pdf, acesso em 6/04/2011.
} 
2.2 - Uma revista literária e judaica

Numa perspectiva de resgate do sentido do termo "revista" o artigo de fundo do primeiro número da revista Comentário a apresentava como um órgão

"de função explicativa e orientadora em que os fenômenos e os acontecimentos do momento são apreciados dentro de uma perspectiva mais ampla, submetidos à análise crítica e interpretados de maneira a estimular a reflexão e o debate. ${ }^{197 "}$

Tal definição se aproxima da original por ocasião do aparecimento da palavra "revista" no final século XIX, de acordo com os dicionários de língua portuguesa: "título de certas publicações periódicas, em que são divulgados artigos originais de crítica ou análises de determinados assuntos" ${ }^{198}$. Ana Luiza Martins levantou outras características próprias desse tipo de publicação entre as quais destacamos por se aproximar das de Comentário: "a oferta de leitura fragmentada, não contínua, seletiva e quase sempre uma manifestação da criação de um grupo"199.

Retomando as características originais de quando surgiram as primeiras revistas, Comentário procura se distanciar de uma tendência da época de "publicações semanais profusamente ilustradas" que complementavam a imprensa diária com imagens a serviço das notícias. Oferecia ao leitor "Comentários objetivos e honestos à margem da atualidade" explicando-se enfim o título do periódico. Como criação de um grupo, a revista se propunha servir como meio para o leitor de língua portuguesa pela primeira vez "documentar-se acerca dos problemas" de "uma vida judaica intimamente entrelaçada com a vida das diferentes nações em que os judeus estão

\footnotetext{
${ }^{197}$ In: Comentário no 1, ANO I, 1ํo trimestre, 1960, p. 5.

198 Laudelino Freire, Grande e Novíssimo Dicionário da Língua Portuguesa, Rio de Janeiro, A Noite Editora, 1943 apud Ana Luiza Martins. Revistas em Revista: Imprensa e Práticas Culturais em Tempos de República. São Paulo: Edusp, FAPESP, Imprensa Oficial do Estado, 2001, p. 45.

${ }^{199}$ Ana Luiza Martins. Op. Cit., 2001, p. 46.
} 
integrados" e de "um núcleo judeu com a modalidade política de um Estado", além de "focalizar os aspectos mais diversos da vida brasileira" por se destinar a leitores do Brasil $^{200}$.

Apenas a título de amostragem registramos algumas diferenças e semelhanças entre as revistas judaicas e não-judaicas de cultura para situar Comentário entre elas. As peculiaridades de cada uma se referem ora aos projetos pessoais dos envolvidos na sua direção, ora no seu viés comunitário. Mas é de se notar a difusão na época de revistas com uma proposta fortemente literária.

A partir de conversas que tivemos com colaboradores da revista ${ }^{201}$, esta esteve diretamente vinculada à publicação norte-americana financiada pelo $A J C$, que reunia contribuições de milionários e outros membros da comunidade judaica de lá. Era uma revista de penetração cultural que atingia um público universitário, acadêmico. Segundo a Sra. Lisette Pernidgi, esposa do advogado Joseph Eskenazi Pernidji (1920-2007), diretor da revista no Brasil ${ }^{202}$, a revista teve muita penetração no Brasil, principalmente nas faculdades. Era única na sua especialidade, comparada com outras também culturais como Senhor, ou voltadas para a comunidade judaica como Shalom. A influência da comunidade judaica americana parece ser decisiva nesta diferenciação. Havia o financiamento da AMOCO (American Oil Company) representada por Jacob Blaunstein ${ }^{203}$, conforme depoimento da Sra. Pernidgi, que afirmou ter viajado com o marido diversas vezes aos Estados Unidos e participados em grandes eventos e banquetes com personalidades do governo e diretores das universidades americanas (citou a Brown University) no hotel Waldof Astoria em virtude dos interesses de seus patrocinadores em promover a cultura e combater o racismo, o antissemitismo e o totalitarismo. Jacob Blaustein foi presidente do $A J C$ e pertenceu ao mundo diplomático. Foi através da Embaixada de Israel que o AJC chegou a Pernidji, conhecido "pelo seu poder de persuasão, inteligência e calma", segundo a Sra. LizettePernidji. José Eskenazi foi indicado para ser o representante do AJC no Brasil. Ela nos

\footnotetext{
${ }^{200}$ In: Comentário no 1, ANO I, 1ํ trimestre, 1960, p. 5.

201 Prof. Jacó Guinsburg e Sra. Lizette Pernidji.

202 Entrevista por telefone, em maio de 2009 e pessoalmente no Rio de Janeiro em 6/04/2010.

203 Jacob Blaunstein dono de uma das maiores empresas de petróleo americanas, a American

Oil Company (AMOCO) fundada em 1910, esteve no mundo do serviço diplomático tendo sido presidente do American Jewish Committee. Morreu em 1970.
} 
informou ainda que os patrocinadores de Comentário (AJC) tinham grande penetração em órgãos governamentais, sendo pessoas de muito "peso político e cultural", um "grupo que impunha respeito", "poderosos e privilegiados culturalmente". Os representantes desse grupo vieram diversas vezes ao Rio de Janeiro em função de propagar a revista e foram recebidos sempre por pessoas do governo brasileiro. Mencionou que chegou inclusive a conhecer 0 presidente norte-americano (do qual não recordava o nome naquele momento) numa das idas com seu marido aos Estados Unidos em virtude de questões em torno da revista. Sobre a revista nos informou que ela era fácil de ler e entender, de fácil penetração. Não era popular e sim vendida em livraria, "feita para pensar". José E. Pernidji, não recebia nada por sua função enquanto Diretor da revista e representante do $A J C$ no Brasil: era um "trabalho de envolvimento intelectual".

Deste modo, a revista Comentário diferenciava-se da revista Senhor, por exemplo, uma vez que esta última foi uma grande representante do jornalismo cultural na imprensa brasileira e Comentário parecia ser uma revista mais especializada no âmbito acadêmico, voltada para um "leitor brasileiro culto"204. Lida por intelectuais judeus e não-judeus, essa penetração no meio universitário pode ser exemplificada pelo conteúdo da carta ao "Sócio do Grupo Universitário Hebraico" encontrada dentro de uma das revistas. Neste documento a diretoria da revista apresenta uma promoção de assinatura da revista trimestral e afirma que

"[...] o nível que a revista se propôs manter exclui, naturalmente toda a possibilidade de sensacionalismo e difusão em massa, o que a circunscreve a um público mais seleto. A juventude universitária judia foi um dos nossos mais almejados objetivos, pois lamentamos sempre a escassez de material judaico em português a seu alcance." 205

\footnotetext{
${ }^{204}$ Cf. Introdução de Bem Tsion Tomer ao exemplar da revista especial sobre a Cultura em Israel, In: Comentário, Ano VIII, n. 4, 1967, p. 308.

${ }^{205}$ Carta da Diretoria de In: Comentário para Sócio do Grupo Universitário Hebraico, Rio de Janeiro, agosto de 1961, 1 p. A historiadora Rachel Mizrahi descreve a revista como "fonte de informação dos meios universitários do período". Ver Rachel Mizrahi, Imigrantes Judeus do Oriente Médio - São Paulo e no Rio de Janeiro, São Paulo, Ateliê Editorial, 2003, p. 253.
} 
Senhor foi "feita para um público com alto poder aquisitivo, residente nos centros urbanos, intelectualizado, sofisticado ou com desejo de sê-lo"206. O objetivo era de oferecer cultura e refinamento às classes dirigentes ${ }^{207}$. A revista tinha um estilo de produção situada entre a jornalística os "campos especializados". Muitos dos nomes que escreveram em uma revista também escreveram na outra, tais como Clarice Lispector, Anísio Teixeira e Otto Maria Carpeaux. Havia uma aproximação, mas Comentário, parece se encaixar mais enquanto uma revista de "campos especializados" enquanto Senhor se situava entre a produção jornalística e os campos especializados e seus colaboradores eram pagos por seus textos. Ambas surgiram numa época de prosperidade e auge da modernidade brasileira. As duas vendiam pouco provavelmente por terem como público-alvo uma elite cultural e, no caso de Senhor, uma elite econômica em formação. E o que mais diferenciava a revista Comentário de Senhor era, obviamente o fato dela procurar por artigos que abordassem majoritariamente os problemas ligados ao judaísmo e a Israel, não sem negligenciar as questões culturais nacionais contemporâneas promovendo debates e inquéritos.

A revista Comentário, por sua vez, recebia financiamento da comunidade judaica norte-americana $(A J C)$, condição que fez a diferença para a sua sobrevivência. Comentário tinha os direitos exclusivos para o Brasil dos artigos publicados em Commentary de Nova lorque, Comentario de Buenos Aires, Evidences de Paris e AMOT de Israel. Em Portugal Comentário era representada por I. Steinhardt, conforme consta na página de "Expediente" da revista. Havia representantes da revista brasileira em São Paulo, Porto Alegre, Recife, Belo Horizonte, Curitiba, Niterói, Santos, Manaus e Belém ${ }^{208}$. As condições financeiras e envolvimento com órgãos governamentais são cruciais para se compreender o processo de "sobrevivência" da revista.

Segundo o editor Jacob Guinsburg e Bóris Schnaiderman, ambos professores da Universidade de São Paulo e membros do Conselho Editorial, sempre houve liberdade para se escrever, autonomia na escolha de temas em

\footnotetext{
${ }^{206}$ BASSO, E. F. C. "Revista Senhor: Jornalismo Cultural na Imprensa Brasileira". Unirevista Vol. 1, no 3 (julho de 2006), p. 1.

${ }^{207}$ Idem, p. 3.

${ }^{208}$ Eram eles, respectivamente a cada estado citado: Alfred Hirschberg, Dr. Herbert Caro, Moyses Braia, Jacob Voloch, Nicolau Rottmann, Adolf G. Kaufmann, Dr. Benjamin Goldenberg, David J. Israel, Jayme Bentes.
} 
relação à Diretoria sediada no Rio de Janeiro, de modo que os intelectuais colaboradores trabalharam livremente. Essa apregoada liberdade de expressão era capaz de conquistar colaboradores do mais alto nível, e o fez, por exemplo, em relação à revista Encounter financiada de maneira camuflada pelo serviço secreto britânico e norte-americano enquanto veículo de ideias anticomunistas ${ }^{209}$. Os artigos reproduzidos da revista americana Commentary, não passavam pela seleção dos editores de São Paulo e representavam uma propaganda norte-americana, justificada principalmente pelo descontentamento dos intelectuais diante da opressão stalinista.

Este profundo desapontamento, especificamente dos intelectuais judeus americanos diante do stalinismo é demarcado na revista brasileira, sensível ao primeiro rompimento entre Israel e União soviética em 1953. Este fato occoreu logo após Stálin ter acusado um grupo de médicos soviéticos, majoritariamente formado por judeus, de tramar a morte de líderes militares soviéticos, o chamado "Complô dos Médicos", associado a uma "organização de espionagem sionista" conforme o Pravda de 13/01/1953 ${ }^{210}$. A reprodução de textos de Commentary no primeiro número da revista brasileira, demonstra esse sentimento. A crítica à União Soviética aparece ressentida nas palavras do escritor norte-americano Howard Fast a respeito de Boris Pasternak, autor da novela Dr. Jivago:

"As expressões do autor temidas pelos burocratas soviéticos
são as decorrentes de sua condenação de um período militar
que eles canonizaram. A minha geração, de juventude amarga,
despojada de toda a esperança, aceitou essa canonização, e
muitos de nós consagramos as nossas vidas à luta que nos
consumiu e nos deixou, ao chegarmos à maturidade, com a
mente enfêrma e ressentidos porque a ilusão soviética se
fragmentou.

Howard Fast rompeu com o Partido Comunista no final da década de 1950, tal como outros tantos intelectuais o fizeram após a divulgação do relatório Kruschev. As perseguições sofridas pelos escritores e artistas judeus seguiram retratadas na revista brasileira, por exemplo, pelo poeta iídiche

\footnotetext{
${ }^{209}$ Ver Frances Stonor Saunders. Op. Cit., 2008, pp. 185-210.

${ }^{210}$ Theodore Draper, "Israel e a Política Mundial", In: Comentário, ANO VIII, n. 3, 1967, p. 219.

${ }^{211}$ Howard Fast, “A Provação de Bóris Pasternak”, In: Comentário, № 1, ANO I, 1960, p. 14.
} 
Abraham Suzkewer em seu relato sobre o poeta Perez Markish, massacrado junto com outros expoentes da cultura iídiche na Rússia stalinista assim como por Boris Schneidermann apresentando o escritor judeu Óssip Mandelstam, também como vítima dos expurgos da era stalinista ${ }^{212}$.

Nessa mesma linha de apontar o antissemitsmo na Rússia está ainda o artigo de Joseph B. Schechtman a respeito de Babiy-Yar em Kiev onde mais de 30.000 judeus foram executados durante a ocupação alemã em 1941. Nikita Kruschev, inclusive, havia prometido um monumento em memória às vítimas do massacre em 1943, promessa que não havia sido cumprida ainda em 1959, ano em que $\mathrm{o}$ artigo foi escrito para a revista sionista Midstream. $\mathrm{O}$ autor então se perguntava por que os chefes do Kremlin ainda insistiam em obliterar a memória de Babiy-Yar, acusando uma posição antissemita por parte da Rússia.

$\mathrm{O}$ artigo de T. R. Fyvel sobre "A vida tormentosa de llya Ehrenburg" sugeriu que o escritor soviético havia pactuado com as autoridades soviéticas, fazendo no final uma ponderação leve a favor do escritor judeu. Mas, não deixou de questionar como ele havia sobrevivido à campanha levada a efeito por Stálin de 1948 a 1953 contra os "cosmopolitas desarraigados", como o ditador chamou os judeus ${ }^{213}$. O escritor sofreu uma série de acusações e em 1969, Comentário publicou um artigo que o redimiu ${ }^{214}$.

O totalitarismo foi também foco de diversas análises da revista, dentre as quais destacamos a do "sovietologista" ${ }^{215}$ Richard Lowenthal que escreveu para Commentary, sendo seu texto reproduzido na revista brasileira (primeiro artigo, tal qual o de Howard Fast). Lowenthal analisou os regimes totalitários fascistas e comunistas do século $\mathrm{XX}$, e o processo revolucionário neles institucionalizado.

No entanto, a partir de outra perspectiva, o sociólogo José Arthur Rios no segundo número de Comentário de 1964 analisou "As novas formas do terror totalitário" a partir do terror nazista, tratando dos métodos psicológicos

${ }^{212}$ Boris Schneidermann, "Óssip Mandelstam”, In: Comentário, N. 3, ANO, III, 1962, pp. 279282.

${ }^{213}$ T. R. Fyvel, "A vida tormentosa de llya Ehrenburg", In: Comentário, Ano III, n. 4, 1962, pp. 295-308.

${ }^{214}$ S. L. Schneiderman, “llya Ehrenburg: revisão ou redenção?”, In: Comentário, m. 1, Ano X, 1969, pp. 15-30.

${ }^{215}$ Expressão utilizada por Norman Podhoret em seu livro Ex-Friends. Falling out with Allen Guinsberg, Lionel and Diana Trilling, Lillian Hellman, Hanna Arendt, and Norman Mailer, California: Encounter Books, 2000, p. 79. 
soviéticos aplicados nas confissões chinesas e do então recente macartismo nos Estados Unidos (1950). O totalitarismo foi avaliado, inclusive, em sociedades liberais como os Estados Unidos e França, de modo que o autor apresentou não apenas o paradoxo esquerda-direita (comunismo-nazismo) totalitárias tão comum nos artigos anticomunistas de Commentary, como também incluiu as sociedades liberais ampliando a visão ideológica a respeito do totalitarismo para uma reflexão a respeito da própria estrutura da civilização ${ }^{216}$.

A revista Comentário não teve problemas de censura no período que esteve em circulação, apesar da intensa repressão das ideias durante a Ditadura Militar, segundo Lizette Pernidji, Jacob Guinsburg e Boris Schnaiderman ${ }^{217}$, viúva do Diretor da revista e membros do Conselho Editorial, respectivamentem, tendo sido Jacob Guinsburg o Editor responsável pela revista em São Paulo.

A revista Shalom, por sua vez, voltada para o público judaico começou mais tarde, em 1965. Boris Schnaiderman também participou da Comissão Editorial dela. Comentário estava associada à revista norte-americana Commentary que era de uma linha bastante conservadora, segundo Boris Schnaiderman. Para a Comissão de São Paulo havia uma orientação diferente procurando-se ampliar o quadro dos colaboradores num período de repressão sustentada pela ditadura militar. Não se procurava afrontar a censura ou 0 regime, mas, segundo Schnaiderman buscavam-se "materiais que de algum modo dessem uma orientação menos conservadora". A Shalom, tinha uma visão mais aberta e crítica a algumas posturas do Estado de Israel. Era a favor, por exemplo, da negociação com os palestinos, do reconhecimento do estado Palestino, além de posicionar-se contra a invasão do Líbano por Israel em 1982. Segundo nos relatou, Schnaiderman participara de um abaixo-assinado que defendia tais posições, o que lhe rendeu críticas por parte da comunidade.

A revista paulista Anhembi aparece anunciada em Comentário a partir do segundo trimestre de 1960, em todos os números do ano de 1961 e no

\footnotetext{
${ }^{216}$ José Arthur Rios, "As novas formas do terror totalitário", In: Comentário, Ano V, № 3, 1964, pp.213-220.

217 Entrevistas concedidas a autora por Lizette Pernidji por telefone, em maio de 2009 e pessoalmente no Rio de Janeiro em 6/04/2010; e por Jacob Guinsburg e Bóris Schneiderman em 11/04/2008 e 15/05/2009, respectivamente.
} 
primeiro trimestre de $1962^{218}$ assim como a publicação carioca Jornal de Letras, dirigida por Elísio Condé, anunciado pela primeira vez a partir do segundo número de 1960 até 1970, sendo homenageado em 1969 ao completar 18 anos. Anhembi, como o próprio nome sugere, se auto-definia como "uma publicação para a divulgação da cultura brasileira". A revista paulista Convivium da Sociedade Brasileira de Cultura também foi anunciada em Comentário a partir de 1968 até 1970.

Anhembi, criada em 1950, foi uma revista que se articulava aos campos cultural e acadêmico, saindo de circulação em 1962, em conseqüência da política econômico-financeira que arrasou a pequena imprensa no Brasil ${ }^{219}$. No ano de 1963, Comentário informou a respeito do fim da Anhembi, lamentando a interrupção do $144^{\circ}$ número mensal. Não perdeu a oportunidade de chamar a atenção para as "muitas atitudes vigorosas e decididas" de Paulo Duarte, "seu publicista", que teriam provocado protestos às vezes de seus próprios admiradores. O texto atribuiu à independência de Paulo Duarte como "um dos motivos que tornaram cada vez mais difícil a manutenção da revista". O registro da despedida se deu em tom de admiração e pesar diante do encerramento do periódico que lembraria "as melhores revistas de cultura e de opinião dos países de cultura mais elevada"220.

Anhembi era um projeto pessoal de seu editor Paulo Duarte e situava-se a meio caminho entre os campos político e cultural. Segundo pesquisa de Mônica Pereira, esse ériódico se aproximava do projeto liberal elitista que acreditava na formação de elites dirigentes ilustradas ${ }^{221}$. De acordo com Luiz Carlos Jackson, Anhembi assemelhava-se a Revista Brasiliense (1955-1964), embora de orientações políticas opostas, as quais

\footnotetext{
${ }^{218}$ Ver In: Comentário oㅜ 4, ANO I, 4ํtrimestre, 1960, p. 2; In: Comentário № 1, ANO II, 1o trimestre, 1961, p. 4; In: Comentário oㅡ 2 (6), ANO II, $2^{\circ}$ trimestre, 1961, p. 98 quando é anunciado um número especial sobre Israel (Anhembi, № 24); In: Comentário no 3 (7), ANO II vol.2, 3o trimestre, 1961, p. 194; In: Comentário no 4 (8), ANO II, 4ํtimestre, 1961, p. 369; In: Comentário no 1 (9), ANO III - vol.3, 1ํtimestre, 1962, p. 89.

${ }^{219}$ Ver Nelson Werneck Sodré, Historia da Imprensa no Brasil, 4a edição, Rio de Janeiro, Mauad, 1999, p. 413.

${ }^{220}$ Paulo Rónai, "Registro Literário", seção Bibliografia, In: Comentário, ano IV, n. 1, 1963, p. 108.

${ }^{221}$ ônica de S. Gouvêa França Pereira. 1987. Anhembi: criação e perfil de uma revista de cultura. Textos IDESP. Série História das Ciências Sociais, vol. 2 apud JACKSON, Luiz Carlos. A sociologia paulista nas revistas especializadas (1940-1965). Tempo social, São Paulo, v. 16, n. 1, June 2004. In: <http://www.scielo.br/scielo.php?script=sci_arttext\&pid=S0103$20702004000100013 \&$ Ing=en\&nrm=iso $>$. Accesso em 21/01/2011.
} 
[...] serviram também ao debate acadêmico, especialmente às ciências sociais, em decorrência, sobretudo da atuação de Florestan Fernandes, que delas se utilizou como "caixa de ressonância" para a legitimação de seu projeto acadêmico $[\ldots]^{222}$

Importante lembrar que Anhembi e a UNESCO ${ }^{223}$ patrocinaram a pesquisa do grupo de Florestan Fernandes e Roger Bastide (colaborador freqüente da revista) Relações Raciais entre Negros e Brancos em São Paulo, publicada de forma seriada na revista, sendo que os textos principais de autoria de Bastide e Fernandes saíram em 1953. A partir da metade dos anos 1950 Florestan Fernandes atuou quase como editor da revista ao lado de Paulo Duarte $^{224}$.

Havia, portanto, uma crítica cultural e divulgação científica com ênfase nas ciências sociais. Florestan também contribuiu em Comentário tratando da educação no Brasil no ano de 1960, de modo que Comentário também se caracterizava pela crítica cultural e divulgação científica, além da crítica literária e publicação de gêneros literários, dada a formação e talvez por isso o interesse da equipe editorial, sem esquecermos, é claro, do fato dela voltar-se não somente, mas em grande parte para questões relacionadas à cultura judaica. Muitos colaboradores de Comentário também escreviam em Anhembi como o sociólogo Gabriel Bolaffi e o jornalista Marcos Margulies que em Comentário não apenas colaboravam com artigos como também fizeram parte da Comissão Editorial da revista em São Paulo.

A já citada revista Cadernos Brasileiros (1959-1970), dirigida por Afrânio Coutinho e fundada pelo Congress for Cultural Freedom, começou a ser anunciada na revista Comentário a partir do segundo número do ano de 1964

\footnotetext{
222 JACKSON, Luiz Carlos. Op. Cit., 2004.

${ }^{223}$ A Organização Educacional, Científica e Cultural das Nações Unidas (UNESCO) foi criada em 1946 e está situada em Paris. A organização desde sua fundação atua por meio de financiamento de pesquisas e programas educacionais no sentido de combater o preconceito, a intolerância e o racismo. Ver verbete a respeito em CASHMORE, Ellis. Dicionário de Relações Éticas e Raciais. Tradução: Dinah Kleve. São Paulo, Summus, 2000, pp. 549-552. 224 Ídem.
} 
(p. 185) até 1970. Em 1964 Comentário (n. 4, p. 385) publicou a comunicação do concurso de contos que a revista Cadernos Brasileiros organizara em comemoração ao IV Centenário da cidade do Rio de Janeiro. As duas tinham um formato parecido enquanto revistas literárias. Propunham debates, mesas redondas, inquéritos que apenas mudando de nomes tinham por objetivo discutir temas da cultura brasileira como educação, teatro, literatura, entre outros. A semelhança na presença da crítica de livros e poesia também sinalizava uma aproximação.

Muitos intelectuais que escreveram em Comentário também o fizeram em Cadernos Brasileiros, a exemplo dos ensaístas e críticos literários Léo Gilson Ribeiro e Ernst Fromm, por exemplo, assim como o sociólogo José Arthur Rios e o Tenente-coronel Octávio A. Velho. A editora-assistente de Cadernos Brasileiros, Nelida Piñon, publicou em 1965 o conto "Menino Doente" em Comentário. Fernando Py, R. Magalhães Júnior, Prado Kelly, Olýmpio Monat, Manuel Diégues Jr., Carlos Drummont de Andrade, Florestan Fernandes, Vilém Flusser estão entre os colaboradores das duas revistas ${ }^{225}$. Dentre os autores internacionais que publicaram tanto em Comentário (via reprodução de Commentary) e Cadernos Brasileiros, cabe destacar o "sovietologista" ${ }^{26}$ Richard Lowenthal e Theodore Draper, também colaborador da revista Encounter, ligada aos serviços secretos americano e britânico ${ }^{227}$.

Comentário, segundo Boris Schnaiderman teve uma função importante como revista de cultura, "como expressão de um público judeu intelectualizado", e ainda mais naquele momento que havia "um fechamento grande, uma dificuldade de se publicar materiais". Foi um veículo rico em conteúdo e abordagens, publicando não somente temas relacionado ao judaísmo, como também, por exemplo, contos russos traduzidos pelo Professor Boris Schnaiderman de autores que nem eram judeus. Algumas traduções inclusive eram inéditas.

\footnotetext{
${ }^{225}$ Ver Cadernos Brasileiros, ns. 29, 31 e 32, todas do ano de 1965; n. 36 do ano de 1966; n. 39 de 1967 e n. 2 de 1968.

${ }^{226}$ Expressão utilizada por Norman Podhoret em seu livro Ex-Friends. Falling out with Allen Guinsberg, Lionel and Diana Trilling, Lillian Hellman, Hanna Arendt, and Norman Mailer, California: Encounter Books, 2000, p. 79.

${ }^{227}$ Ver, por exemplo, Cadernos Brasileiros, n. 31, 1965, n. 2 de 1966 e n. 2 de 1967.
} 


\title{
2.3 - Ditadura em revista
}

\begin{abstract}
Não acredito seja de fato possível negar que pela competição pela mente dos homens, em especial nas nações que estão surgindo, se encontrem os Estados Unidos em considerável desvantagem. Dá-se isso não por ser a política externa americana capitalista, mas por ser doutrinariamente anticomunista. Por isso apoiará qualquer movimento, governo ou elite que seja tenazmente anticomunista e quanto mais o for, tanto mais terá o apoio americano. Pela lógica dessa posição, temos apoiado através do mundo inteiro as elites, governos e sistemas sociais mais reacionários, mais estéreis e mais inviáveis. Hans J. Morgenthau, "Os Valôres do Ocidente e a Guerra Total" - um debate, In: Comentário, ANO IV, n. 1, 1963, p. 31.28
\end{abstract}

As revistas, semanários e outras publicações do gênero tiveram grande importância a partir da segunda metade do século XX no Brasil, momento de crise na imprensa internacional e nacional condicionada pela primeira, embora com aspectos particulares ${ }^{229}$. Entre as questões enfrentadas pela imprensa na época havia o problema do papel, na maior parte importado e, portanto, sujeito à política de comércio exterior e de câmbio. Da mesma forma devemos considerar que as máquinas para impressão também eram importadas, dificultanto a produção em grande escala ${ }^{230}$.

A produção da revista Comentário, assim com as demais aqui citadas, deve também ser compreendida no contexto da imprensa judaica no Brasil cujo início data de 1915, quando surgiu o primeiro órgão em í́diche, o Di Meinscheit (A Humanidade) criado pelo jornalista argentino Josef Halevi ${ }^{231}$. Em 1916 começaram a surgir os primeiros jornais e revistas em língua portuguesa criados por judeus sefaraditas, tendo sido A Columna (1916-1917) o primeiro jornal israelita, fundado por David José Pérez e Álvaro de Castilho ${ }^{232}$. Os jornais produzidos pelos imigrantes sofreram revezes durante o período

\footnotetext{
${ }^{228}$ Morgenthau foi diretor do Centro de Estudos sobre Política Estrangeira na Universidade de Chicago e dirigiu a seção bimestral "Public Affairs" de Commentary.

${ }^{229}$ Ver análise completa da crise estrutural da imprensa no Brasil a partir da segunda metade do século XX de Nelson Werneck Sodré, Op. cit., pp. 391-449.

${ }^{230}$ Ver a esse respeito o editorial de 18/09/1964 do Correio da Manhã, do Rio que, entre outras denúncias a respeito do 'preço que pagava pela liberdade de opinar', referiu-se ao monopólio Klabin-Lafer do papel aliado ao 'monopólio de opinião, representados pelo governo'. Em Nelson Werneck Sodré, Historia da Imprensa no Brasil, 4⿳亠丷厂 edição, Rio de Janeiro, Mauad, 1999, pp. 411-412 e nota 343, p. 412.

${ }^{231}$ Nachman Falbel, Judeus no Brasil, Estudos e Notas, São Paulo: Humanitas; Edusp, 2008, p. 41.

${ }^{232}$ Ídem, p. 45.
} 
varguista devido à vigilância da polícia política preocupada com a agitação em torno das ideologias européias.

O fim da ditadura Vargas não facilitou para os estrangeiros, pois, a nova Constituição de 1946 determinou que as empresas jornalísticas deveriam ser nacionais, sendo os estrangeiros proibidos de mantê-las, embora tenha havido algumas exceções em relação a grupos norte-americanos ${ }^{233}$. O controle estrangeiro sobre a imprensa brasileira foi se instalando através das agências estrangeiras de publicidade, transformando a imprensa em negócio. Os assuntos de interesse nacional só encontraram espaço para serem tratados em revistas especializadas ${ }^{234}$.

Segundo Nelson Werneck Sodré muitas revistas foram tragadas pela ditadura, principalmente as comunistas, como Problemas; o semanário Novos Rumos; Literatura e Estudos Sociais, fundadas e dirigidas por Astrogildo Pereira; Revista Brasiliense, fundada por Caio Prado Júnior em São Paulo; Publicidade e Negócios, que teve uma segunda fase nacionalista, fundada e dirigida por Genival Rabelo; o Semanário fundada e dirigida por Oswaldo Costa, veículo de estudos de teor nacionalista, entre muitas revistas e jornais estudantis. Muitas desapareceram logo após o golpe em março de $1964^{235}$.

Os anos de 1960 e 1961 abrigaram outras publicações judaicas além de Comentário, como a revista semanal Menorá, publicada no Rio de Janeiro por um grupo de jovens jornalistas. Cabe citar ainda entre as publicações que circulavam nessa época como O Novo Momento, revista em iídiche quinzenal depois semanal com uma página em português; Nossa Voz, publicação semanal bilíngüe iídiche-português representante de uma corrente da esquerda judaica e a Crônica Israelita, publicada quinzenalmente em português pela Congregação Israelita Paulista (CIP). No Rio havia ainda a Imprensa Israelita e o Diario Israelita, dois semanários independentes em iídiche e português; o Jornal Israelita e Aonde Vamos?, cujo editor era Aron Neumann, ambos semanários em português ${ }^{236}$. Al Hamishmar (Há-shomer Ha-tza'ir) e Brasil-

\footnotetext{
${ }^{233}$ Nelson Werneck Sodré, Op. cit., 1999, pp. 396-397.

234 Ídem, pp. 407-408.

${ }^{235}$ A respeito das revistas citadas que desapareceram com a ditadura ver Nelson Werneck Sodré, Op. cit., 1999, pp 408 e 409.

${ }^{236}$ Cf. Alfred Hirschberg e Abraham Monk, "Brasil", Foreign Coutries: Latin America, American Jewish Year Book (AJYB), Vol. 63, 1962, p. 480. In:

http://www.ajcarchives.org/AJC DATA/Files/1962 16 LatinAmerica.pdf, acesso em 6/04/2011.
} 
Israel eram publicadas em português e apareciam de maneira irregular. Ainda havia as mensais Folha da Coletividade e Shalom, em português.

No rádio se escutava o "Programa Mosaico", antigo "Hora Israelita" criado em 1940 e conduzido por Francisco Gotthilf, então Secretário Geral da Federação Israelita do Estado de São Paulo (Fisesp) e na TV Excelsior, um programa com o mesmo nome desde 16 de julho de 1961, todos os domingos na hora do almoço ${ }^{237}$.

A revista trimestral Comentário, criada quatro anos antes de 1964, ou da instauração do regime militar no Brasil, resistiu ao golpe e persistiu durante os anos de maior repressão política. Sobreviveu a decretação do Al5 (13/12/1968) - "a ditadura sem disfarces"238 - e grande parte do governo Médici (30/10/1969 a 15/03/1974). O último número da revista é do ano de 1973.

Em 1960, no terceiro número da Comentário chama atenção o artigo acerca das opções que os países subdesenvolvidos teriam naquele momento em termos de "escolhas ideológicas". A via liberal americana foi colocada pelo intelectual William J. Newman ${ }^{239}$, professor da Universidade de Boston, como uma solução razoável e desejável para os problemas daqueles países em detrimento das aparentes únicas opções: ditadura e comunismo. A ditadura indesejável para o professor que observava o rápido surgimento das ditaduras nos países subdesenvolvidos - é criticada por não ser uma forma de governo, mas o governo de um homem só destinado a preencher lacunas. Ao contrário da tendência, Newman entendia que o liberalismo era aplicável à situação daqueles países, única opção ao lado do comunismo completamente descartado por seu discurso. Comentário veiculava através da reprodução dos artigos de Commentary o anticomunismo norte-americano.

Por meio das manifestações artísticas como o teatro e o cinema muitos expressaram o descontentamento diante da imposição cultural norteamericana, das tensões políticas principalmente a partir de 1964 no Brasil que dividiam as pessoas entre a ideologia comunista e o capitalismo. A presença do teatro é muito forte em Comentário fazendo-se presente através da crítica

\footnotetext{
${ }^{237}$ Cf. Alfred Hirschberg, "Brasil", Foreign Coutries: Latin America, American Jewish Year Book (AJYB), Vol. 67, 1966, p. 302 e 303. In: http://www.ajcarchives.org/AJC DATA/Files/1966 8 LatAmerica.pdf, acesso em 15/04/2011. ${ }^{238}$ Termo empregado no livro Brasil, Nunca Mais. Petrópolis, Editora Vozes, 1996, 28a edição, p. 62.

${ }^{239}$ Ver mais a respeito do autor e citação completa do artigo em “ TABELAS DE AUTORES”.
} 
teatral e da publicação de textos na parte destinada à ficção. Cumpre citar a participação do conceituado autor teatral brasileiro Guilherme Figueiredo que já no primeiro número da revista contribuiu com uma peça em um ato inédita intitulada "O Princípio de Arquimedes" e a peça também inédita em dois atos "O Sorriso de Pedra" de Pedro Bloch publicada no segundo número da revista em 1960. O próprio autor comentou em 1963 sobre a repercussão da sua peça "O Espetáculo não pode parar". Citamos ainda a colaboração de Lúcia Benedetti com a publicação da peça "O Inferno de Rosauro tal como se deu" e do texto sobre o teatro infantil e seus problemas de 1960, um novo gênero literário e que começava a ser objeto de diversos estudos. O breve panorama do teatro em Pernambuco escrito por Joel Pontes, grande promotor do teatro amador no Brasil, informa a respeito de uma efervescência do gênero teatral, principalmente estudantil e amador, que incluía os estudantes israelitas como grupo mantido pela coletividade ${ }^{240}$. Sábato Magaldi, crítico teatral d'O Estado de $S$. Paulo também teve espaço na revista publicando em primeira mão em 1962 um capítulo do seu livro Panorama do Teatro Brasileiro. O foco na questão de gênero aparece no artigo "As mulheres no teatro brasileiro" de Luiza Barreto. Obras clássicas do dramaturgo Johann Christoph Friedrich Schiller receberam análises de especialistas como Raymundo Magalhães $\mathrm{Jr}^{241}$ que resenhou do livro Teoria da Tragédia de Schiller em 1964 publicada na Seção Bibliografia.

Em 1964 Augusto Boal do teatro de Arena de São Paulo, de orientação esquerdista, publicou na revista Comentário "A Arte inoportuna" onde identificou a ascendência do teatro leve, destituído de crítica social em detrimento do que ocorrera no ano de 1960, quando o teatro de esquerda teve uma extraordinária (e artificial) acolhida do público paulista. Boal embora concordasse com a essência da ideia de uma coexistência pacífica no campo das artes defendida por Sartre em seu discurso no Congresso pelo Desarmamento Geral e pela Paz Mundial realizado em Moscou em junho de 1963. Discordou dela para aquele momento, afirmando que ninguém no Brasil

\footnotetext{
${ }^{240}$ Ver a referência destes e outros textos destes autores na tabela de "Autores Nacionais" em "Tabelas".

241 "Schiller e o Problema da Liberdade", In: Comentário, Ano II, no. 1, 1960, pp. 63-64.
} 
poderia aceitar o seu desafio pois "todos acham-se empenhados até a alma na fase mais aguda da luta ${ }^{242}$."

Sobre o cinema esteve presente a nouvelle vague com Luc Godard por J. G. Weightman que observou as convenções americanas sendo impostas ao ambiente francês numa crítica a Sartre que ao lado de outros escritores do pósguerra estaria passando por uma crise de engagement ${ }^{243}$.

No Brasil, o crítico de cinema J. S. Ismael criticou a incorporação do ideal desenvolvimentista importado, embora não houvesse "nos últimos 30 anos alteração alguma na estrutura econômica do país que permita supor a necessidade de uma modificação na estrutura mental das suas elites." Ismael teceu uma crítica ao cinema norte-americano e os expurgos anticomunistas de elementos da esquerda, estes capazes de trazer à consciência "epifenômenos" em qualquer esquema cultural que participassem. O crítico via no cinema neorealista perspectivas de resgate de uma verdade anestesiada por produções alienantes. A crítica ao engajamento social na arte em termos de denúncia veio em seguida enquanto um falseamento da obra de arte, exemplificando a tendência desenvolvimentista que colocava como única verdade a urgência de um "sentimento euforicamente nacionalista". O cinema novo de influência neorealista precisava não apenas atuar no momento, mas sobreviver, segundo |smael $^{244}$.

No momento do golpe um grupo de intelectuais judeus que participava de grupos de esquerda apoiou João Goulart. A "Casa do Povo" em São Paulo, um centro iídiche de judeus progressistas, chegou a ser investigada pelo DEOPS/SP ${ }^{245}$. Havia também judeus militares como Isaac Nahoum ${ }^{246}$. De acordo com Alfred Hirschberg em 1967 a posição dos judeus no Brasil não havia sido afetada pelas tendências políticas. Nas eleições gerais de novembro do ano de 1966 havia seis judeus entre MDB e ARENA que haviam sido eleitos

\footnotetext{
${ }^{242}$ Ver referência na Tabela de Autores Nacionais.

243 “A Nova Onda na Cultura Francesa”, In: Comentário, 1961, n 2, ano II, pp. 124-134.

${ }^{244}$ Ver referência na Tabela de Autores Nacionais.

${ }^{245}$ Cf. Alfred Hirschberg, "Brasil", Foreign Coutries: Latin America, American Jewish Year Book (AJYB), Vol. 66, 1965, p. 341. In: http://www.ajcarchives.org/AJC DATA/Files/1965 8 LatAmerica.pdf, acesso em 6/04/2011. ${ }^{246}$ Cf. Alfred Hirschberg, "Brasil", Foreign Coutries: Latin America, American Jewish Year Book (AJYB), Vol. 67, 1966, p. 305. In: http://www.ajcarchives.org/AJC DATA/Files/1966 8 LatAmerica.pdf, acesso em 15/04/2011.
} 
para a Câmara dos Deputados (Guanabara, São Paulo, Paraná e Amazonas), o maior número em um único pleito ${ }^{247}$.

Detectamos entre os colaboradores de Comentário nomes de intelectuais judeus alinhados com o campo da esquerda que atuaram em associações culturais nas décadas de 1920, 1930 e 1940, muitas das quais perseguidas pela Polícia Política sob suspeita de exercerem atividades comunistas. Cito como exemplo, Samuel Malamud, da Biblioteca Israelita Scholem Aleichem (BIBSA) no Rio de Janeiro, que congregava os judeus progressistas, muitos deles ativistas filiados ao PCB. A BIBSA chegou a ser vigiada pela polícia em virtude de sua "tendência comunista" até os anos de $1950^{248}$. Samuel Malamud fez parte da Comissão Editorial de Comentário e do Conselho Editorial do tablóide A Voz Sionista. Conhecedor da história do movimento sionista escreveu artigos para Comentário sobre o tema ${ }^{249}$, além de fazer parte do Conselho Editorial da revista a partir do ano de 1965.

Em agoto de 1964, poucos meses após o golpe, a convite do Instituto Brasileiro Judaico de Cultura e Divulgação (IBJCD), uma delegação do American Jewish Committee (AJC) visitou Brasília, Rio de Janeiro e São Paulo. Foi recebida pelo Presidente Castelo Branco, que condenou o totalitarismo, pelo presidente do Supremo Tribunal Federal, além de senadores e deputados. Ainda visitou lideranças religiosas católicas no Rio de Janeiro e em São Paulo, que condenaram o antissemitismo e fez doações de livros à Universidade de São Paulo participando ainda de recepções comunitárias. A presença deles foi amplamente divulgada pela imprensa ${ }^{250}$.

Comentário se posicionou nesse sentido enquanto um segmento da chamada "imprensa alternativa", ou "imprensa de resistência" por lutar pelos

${ }^{247}$ Cf. Alfred Hirschberg, "Brasil”, Foreign Coutries: Latin America, American Jewish Year Book (AJYB), Vol. 68, 1967, p. 288. In: http://www.ajcarchives.org/AJC DATA/Files/1967 8 LatAmerica.pdf, acesso em 15/04/2011.

${ }^{248}$ A respeito da BIBSA e de Samuel Malamud, ver Cf. Esther Kuperman, "ASA - Gênese e Trajetória da esquerda judaica não sionista carioca". In: Revista Espaço Acadêmico, № 28, Setembro de 2003, Mensal, ISSN 1519.6186 (www.espacoacademico.com.br, acessado em 9/5/2008 e 06/04/2011).

${ }^{249}$ Ver "O Roteiro de uma ideia", In: Comentário, Ano II, no. 3, 1961, pp. 209-218; "David BenGurion: o homem e o Estadista", In: Comentário, Ano III, no. 3, 1962, pp. 226-234; "As experiências de coletivização do Estado de Israel", In: Comentário, Ano VI, n. 1, 1965, pp. 3541. Escreveu ainda sobre "Mêndeli - O patriarca da moderna literatura yidisch", In: Comentário, Ano V, no. 2, 1964, pp. 166-176.

${ }^{250}$ Cf. Alfred Hirschberg, "Brasil", Foreign Coutries: Latin America, American Jewish Year Book (AJYB), Vol. 66, 1965, p. 342. In: http://www.ajcarchives.org/AJC DATA/Files/1965 8 LatAmerica.pdf, acesso em 6/04/2011. 
direitos das minorias valendo de estratégias culturais, multidiscilplinares e defender uma causa: o combate ao antissemitismo, racismo e totalitarismo. Sua sobrevivência em pleno regime militar, talvez se explique pelo fato de seus autores não fazerem uma contestação "direta" ao regime. No entanto, nas suas entrelinhas, persistia embutido o apelo a uma ampla reforma democrática.

Assim, em alguns artigos a crítica ao regime aparece cuidadosa. É o caso do artigo do sociólogo Henrique Rattner "A América Latina na Encruzilhada", publicado no terceiro trimestre de 1965. O resumo do texto demonstra a delicadeza necessária para se tocar em determinados assuntos:

"O presente artigo é uma análise fria, desprovida de coloração política e sem intenção outra que não seja a constatação do fenômeno e a busca de melhoria." ${ }^{251}$

Rattner, sociólogo da Universidade de São Paulo vinha pesquisando os "desenvolvimentos econômicos" na América Latina naquela "época de transformações e inquietudes sociais". Ao analisar a estrutura social e política em mudanças referiu-se ao constante histórico de "assaltos ao 'poder", situações que impediam, ao seu ver, o lançamento dos "fundamentos de um regime livre e de uma sociedade democrática estável". As tensões e os conflitos que estariam por vir diante da transformação social e política já vinham ocorrendo na América Latina sendo previstas e temidas por Hattner ${ }^{252}$.

Outro sociólogo que fortalecia esta corrente era José Arthur Rios que, através da resenha do livro Evolução da Crise Brasileira, de Afonso Arinos de Mello Franco, salientou que "revolução sem legalidade não é democracia, mas ditadura, seja de classes, seja de partido, seja militar". Através dessa crítica não tão velada, insistiu num planejamento democrático ou "revolução consentida" ${ }^{253}$.]

No relatório de Alfred Hirschberg para o $A J Y B$, datado de 1967 a respeito do ano de 1966 transparece o clima de tensão diante das ações que vinham ocorrendo desde a derrubada de João Goulart, o golpe em 1964 e a

\footnotetext{
${ }^{251}$ Henrique Rattner, "A América Latina na Encruzilhada”, In: Comentário, Ano VI, n. 3, 1965, p. 197.

${ }^{252}$ Ver sua história de vida junto ao link "testemunhos" do portal WWW.arqshoah.com.br. 253 José Arthur Rios, resenha de Afonso Arinos de Mello Franco, Evolução da Crise Brasileira, São Paulo: Companhia Editora Nacional, 1965. In: In: Comentário, Ano VI, n. 4, 1965, pp. 371372.
} 
'ideologia' cada vez mais dominante de "segurança nacional" elaborada pela Escola Superior de Guerra (ESG). O Ato Institucional n. 3 havia sido decretado e o relator estava impressionado com o poder presidencial:

The most impressive proof of presidential Power was the sudden disappearence of São Paulo's Governor Adhemar de Barros from the political scene. He had been a key figure in the 1964 uprising, cut, in march 1966, he began voicing severe criticism of the regime's economic policy wich caused wide discontent in São Paulo industrial and commercial circles. In June he was suddenly ousted from the governorship, his political rights were suspended and he left for Europe to avoid imprisonment. ${ }^{254}$

Os relatórios anuais seguintes vão descrevendo à medida que se torna mais acentuado o controle militar da federação sobre os estados e os atos institucionais presidenciais. Crucial para a anulação da liberdade de expressão e de cidadania foi o Ato Institucional n. 5 (AI5) baixado em 13 de dezembro de 1968 pelo Marechal Costa e Silva autorizando o Presidente da República a decretar o recesso do Congresso por tempo indeterminado, restringir direitos individuais, suspender o intrumento do habeas corpus em relação aos crimes de natureza política, aos crimes contra a segurança nacional e os de ordem econômica, suspender os direitos políticos de qualquer cidadão por dez anos e cassar mandatos parlamentares. A ironia estava na justificativa de que o Al5 se fazia "em nome da defesa das instituições democráticas"255. As manifestações políticas contra a ditadura foram duramente reprimidas e muitas vezes custaram muitas vidas ${ }^{256}$.

\footnotetext{
254 "A prova mais impressionante do poder presidencial foi o desaparecimento repentino do governador paulista Adhemar de Barros, da cena política. Ele tinha sido uma figura-chave na rebelião de 1964, cortada em março de 1966 quando ele começou a manifestar severas críticas da política econômica do regime que causou grande descontentamento nos círculos industriais e comerciais de São Paulo. Em junho, de repente, ele foi expulso do governo, seus direitos políticos foram suspensos e ele partiu para a Europa a fim de evitar a prisão." Cf. Alfred Hirschberg, "Brasil", Foreign Coutries: Latin America, American Jewish Year Book (AJYB), Vol. 68, 1967, pp. 284-285. In: http://www.ajcarchives.org/AJC DATA/Files/1967 8 LatAmerica.pdf, acesso em 15/04/2011.

${ }^{255}$ Cf. Alfred Hirschberg "Brasil", Foreign Coutries: Latin America, American Jewish Year Book (AJYB), Vol. 70, 1969, pp. 307-308. In: http://www.ajcarchives.org/AJC DATA/Files/1969 7 LatinAmerica.pdf, acesso em 17/04/2011. ${ }^{256}$ Cf. Brasil: Nunca Mais, prefácio de Dom Paulo Evaristo Arns, Editora Vozes, Petrópolis, 1996; Janaína Teles (org.), Mortos e Desparecidos Políticos: Reparação ou impunidade?, São Paulo, Humanitas, 2001; Direito à verdade e à memória: Comissão Especial sobre Mortos e Desaparecidos Políticos - Brasília, Secretaria Especial dos Direitos Humanos, 2007.
} 
Alfred Hirschberg em relatório anual de 1969 expôs a ação de dois movimentos que se opuseram dentro da Igreja: um conservador fundado em 1960 por Plínio Correia de Oliveira e liderado pelo Bispo Proença Sigaud, cujo lema era "Tradição, Família e Propriedade" e outro, progressista, liderado pelo Arcebispo Helder Camara de Olinda e Recife que defendia a "Verdade, Justiça e Paz"257.

Naquele ano de 1968, Henrique Rattner publicou na revista o texto "A Luta pela Hegemonia Social" onde analisou a política externa norte-americana. O resumo deste artigo publicado pela revista revela a posição cuidadosa dos responsáveis pela publicação ao referir-se às colocações de Rattner:

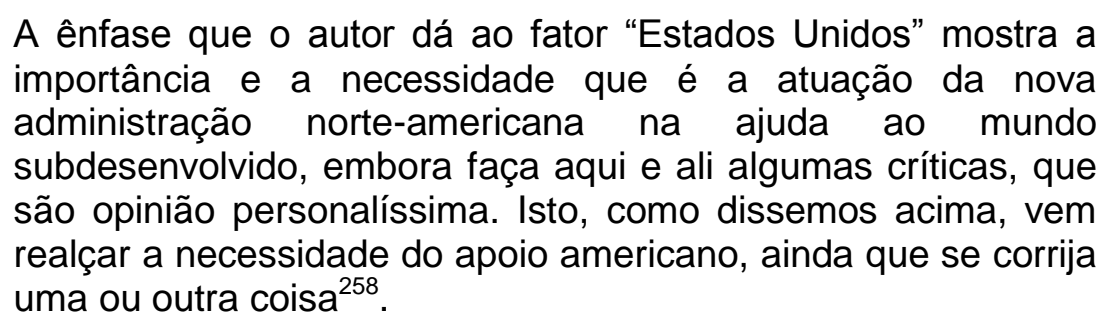

Rattner atribuiu à extrema miséria e ao subdesenvolvimento dos países pobres o perigo à segurança e estabilidade dos países ricos e não às "supostas conspirações e ações subversivas", classificando de inadequada a política externa norte-americana. As tentativas da população de intervir no processo político eram "brutalmente reprimidas pelas elites tradicionais" sustentadas pelas forças armadas. Segundo o autor, as forças armadas estavam sob intervenção direta dos representantes oficiais do Estados Unidos nos países latino-americanos ou eram apoiadas por eles. Rattner chegou à conclusão de que a defesa da democracia contra o perigo da tomada de poder por elementos de esquerda serviou, em última análise, ao fortalecimento no poder de grupos minoritários, talvez muito menos "democráticos" que os governos depostos. Enfim, "um retrato do que estava acontecendo no Brasil". Além deste comentário - aliás, bastante crítico e nenhum pouco sutil - Rattner fez também uma severa crítica às transgressões flagrantes dos princípios do Direito

${ }^{257}$ Cf. Alfred Hirschberg "Brasil", Foreign Coutries: Latin America, American Jewish Year Book (AJYB), Vol. 70, 1969, pp. 307-308. In: http://www.ajcarchives.org/AJC DATA/Files/1969 7 LatinAmerica.pdf, acesso em 17/04/2011. ${ }^{258}$ Henrique Rattner, "A luta pela Hegemonia Mundial", In: Comentário, Ano IX, n. 4, 1968, p. 313. 
Internacional e da Carta das Nações Unidas cometidas pelos Estados Unidos no Vietnam ${ }^{259}$.

Sobre as circunstâncias que culminaram com o fechamento da revista Comentário em 1973, Jacó Guinsburg, então editor responsável considera que apesar da real política de inter-relação promovida pela revista entre as comunidades judaicas de Brasil e Argentina e não-judaicas ocorreram problemas de censura e de crise demarcando os anos de 1969 e 1970, definidos como "anos insuportáveis". "As pessoas não estavam aceitando a opressão." Havia, segundo Guinsburg, um duplo perigo: "estava-se forçando a barra para dar saída de voz à oposição não diretamente, mas através de um livre acesso". Guinsburg lembrou também que o diretor estava sujeito a ser preso. Nunca houve nada, no entanto. Pesava também o fato de Pernidji estar ligado profissionalmente com os militares tendo escrito um livro sobre a guerra dos Paraguai ${ }^{260}$, entre outros. Para Guinsburg: "Tem-se a impressão que depois da saída de São Paulo (do Conselho Editorial) a coisa não resistiu muito tempo"261.

A partir do terceiro trimestre de 1970, a Comissão Editorial de São Paulo se desfez, sendo a revista composta e impressa no Rio de Janeiro. Guinsburg pediu demissão que foi aceita pela direção no Rio "o que pareceu absurdo a todos na época porque se desconhecia o outro lado", segundo testemunho do próprio Guinsburg. Marcos Margulies assumiu a direção da revista, então no seu segundo número do ano de 1971, que demarcou as transformações editoriais e gráficas a começar com um novo subtítulo: "a revista que comenta o mundo e seus problemas". Visualmente a revista foi enriquecida com um maior número de fotografias que, ao lado dos textos, extrapolavam a condição de mera ilustração. Outra alteração a ser ressaltada: alguns artigos vinham com a frase: "nós discordamos do autor", expressando a posição editorial da revista que abria espaço para opiniões divergentes instigando o debate. De

\footnotetext{
259 Ídem, pp. 318-321.

260 Joseph Eskenazi Pernidji, Homens e Mulheres na Guerra do Paraguais, Rio de Janeiro, Imago Editora, 2003.

${ }^{261}$ Entrevista concedida a autora por Jacob Guinsburg em São Paulo, 11/04/2008.
} 
acordo com Marcos Margulies para o $A J Y B$, naquela época Comentário era considerada uma das principais revistas intelectuais do Brasil ${ }^{262}$.

A Comentario argentina desapareceu em 1971 devido à crise econômica naquele país, segundo informou Nissin Elnecave para o $A J Y B^{263}$. Comentário despareceu um pouco depois no ano de 1973. Em termos de circulação, penetração e estabilização, a revista não foi bem sucedida, de acordo com Guinsburg. O fechamento dela também se deu por não haver autosustentação, dependendo de subsídios financeiros que garantissem a sua continuidade. Ainda segundo Guinsburg, não se tratava de uma revista sionista: "o Estado de Israel era um tema de apoio e crítica". O fato dela não ter penetração na coletividade judaica brasileira acabou por minar suas bases culminando com o seu fechamento. Nos EUA a Commentary "vingou", na opinião do seu ex-editor em São Paulo porque o American Jewish Committee, através de Jacob Blaustein, investiu pesadamente naquele projeto. Conseguiram uma grande penetração pelo tipo de trabalho que realizaram junto a comunidade judaica nos EUA que representava uma massa organizada enquanto no Brasil ainda estávamos engatinhando nesse sentido.

Retomando J. Guinsburg: os aspectos políticos são dois, de um lado a revista tinha uma postura democrática aberta, antirracista, antissemita, contra as discriminações de todo o tipo; de outro havia os interesses políticos, mas que acabaram sendo neutralizados. Inquieto e crítico Guinburg pergunta: "Se fosse uma publicação eminentemente conservadora, porque teriam convidado uma comissão editorial desse tipo? Porque ninguém ali atenderia imposições absurdas", afirma. Havia liberdade para se trabalhar. "Por exemplo, tínhamos Celso Lafer ${ }^{264}$, um jovem intelectual ainda. Anatol Rosenfeld, Henrique Rattner, Anita Novinsky, pessoas com reconhecidas posturas políticas e acadêmicas. Muitos vieram inclusive da esquerda, Anatol Rosenfeld tinha uma posição

\footnotetext{
${ }^{262}$ Cf. Marcos Margulies, "Brasil", Foreign Coutries: Latin America, American Jewish Year Book (AJYB), Vol. 74, 1973, p. 326.. In: http://www.ajcarchives.org/AJC DATA/Files/1973 7 LatinAmerica.pdf, acesso em 18/04/2011. ${ }^{263}$ Cf. Nissim Elnecave, "Argentina", Foreign Coutries: Latin America, American Jewish Year Book (AJYB), Vol. 73, 1972, p. 436. In: http://www.ajcarchives.org/AJC DATA/Files/1972 8 LatinAmerica.pdf, acesso em 18/04/2011.

${ }^{264}$ Celso Lafer escreveu o artigo "Notas para um estudo do judeu em Gil Vicente", In: Comentário, Ano III, n. 1, 1962, pp. 73-83. Naquela época tinha apenas 21 anos e era estudante da Faculdade de Direito e da Faculdade de Filosofia, Ciências e Letras da Universidade de São Paulo.
} 
bastante à esquerda e o próprio Jacob Guinsburg. Na sua opinião, "o que não dava para aceitar era a censura", um dos motivos (e também um pretexto) diante da crise que vinha se desenvolvendo. Importante lembrar que participavam também do conselho daquela época alguns senadores da República, além do católico Hamilton Nogueira e outros.

Enfim podemos considerar que Comentário foi uma revista de vanguarda por ser uma revista de resistência cultural aberta para múltiplas temáticas e campos do conhecimento. Como definiu J. Guinsburg:

"Se ela não vingou pelas suas raízes terem sido rasas, a árvore foi frondosa, talvez tenha sido uma flor de verão". Mas há toda uma história intelectual e social a ser resgatada." 265

${ }^{265}$ Entrevista concedida a autora por Jacob Guinsburg em São Paulo, 11/04/2008. 


\section{III - O Mal-estar na cultura em Comentário}

3.1. Integration without assimilation: lema e dilema de ser judeu

Em ambas estas atitudes - a conservadora e a revolucionária o místico descobre novamente a própria experiência no texto sagrado $^{266}$.

O vínculo estabelecido entre o povo judeu e a cultura relaciona-se com a Torá o que o levou ser conhecido como "o povo do Livro". A emancipação judaica resumidamente coincidiu com o desenvolvimento da democracia, da maturidade política européia, da industrialização e do avanço do capitalismo. Tudo isso gerou um alargamento de horizontes culturais no universo judaico. $O$ século XVIII testemunhou as novas necessidades culturais a que aspirava 0 mundo judaico; um movimento chamado de Haskalá, conhecido também como o iluminismo judaico se desenvolveu na Alemanha, Holanda, Áustria, Ucrânia, Polônia e Rússia. Um de seus fundamentos era a cultura, ou a expansão da inteligência o que levou o judeu moderno a entregar-se às ciências, às técnicas e às artes do Ocidente, devendo conciliar essa integração real às qualidades distintivas de seu povo. No entanto, a expansão e a integração foram além, de modo que os laços tradicionais judaicos se tornaram no século XIX e início do XX esmaecidos e quase apagados e muitos casos. A perseguição aos judeus foi retomada no final do século XIX, reaparecendo através dos pogroms na Rússia e, finalmente, recrudescendo com o nazismo na Alemanha e países colaboracionistas.

O trauma pós Holocausto se impôs definitivamente - e se impõe até os dias de hoje - como uma ferida aberta cuja dificuldade de cicatrização resulta (tem resultado) em repetidas tentativas de cura. Elaborar esse trauma parecenos ser uma das tarefas desses intelectuais ainda sob o impacto da barbárie. A revista se apresenta como um dos resultados desse trabalho ao refletir sobre a natureza da cultura em que se está inserido. Freud descreveu a palavra cultura

\footnotetext{
${ }^{266}$ Gershom Scholem, "Autoridade Religiosa e Misticismo", In: Comentário, Ano VI, n. 1, 1965,
} pp. $42-54$. 
enquanto a soma integral das operações e normas/ regulamentos que servem para proteger-nos contra a natureza e para ajustar-nos em nossos relacionamentos mútuos ${ }^{267}$. Proveniente de uma estrutura da qual faz parte a ideia de comunidade (imaginada), a revista Comentário "comentava" as dimensões da existência humana com um objetivo de estabelecer vínculos ou identificações com a sociedade brasileira durante a década de 1960.

No contexto do surgimento da revista americana o movimento solidário resultante do mesmo fato histórico (Shoah) revigorou um ideal identitário esmaecido pelo período de emancipação na Europa e sincronizou grupos judaicos espalhados pelo mundo durante o período que teve como pano de fundo os conflitos no Oriente Médio resultantes de 1948. Cabe enfatizar, que o advento do Estado de Israel dividiu opiniões, inclusive entre judeus, sobre a sua legitimidade, colocando o judeu da Diáspora numa posição de destaque e delicada. O investimento libidinal em torno da construção de um Estado para um povo foi de tal ordem que gerou um fato sem precedentes na história mundial: o renascimento de uma língua (enquanto outra foi aos poucos se perdendo - o iídiche), recuperando uma tradição que extrapolava a religião.

Quando Comentário aborda cultura, entendemos que esteja engajada num movimento capaz de promover a divulgação e o interesse em torno da cultura judaica no meio da elite intelectual e política brasileira visando reconhecimento social, alinhando-se ao discurso democrático do qual tomou frente. Trata-se de um esforço na manutenção de uma direção de relacionamento que, pode-se afirmar, tenha oficialmente começado com 0 emblemático papel representado pela diplomacia brasileira quando da criação do Estado de Israel, na Assembléia Geral da ONU em 14 de maio de 1948, presidida pelo Embaixador Oswaldo Aranha. Um esforço que se reúne a outras forças, que são as organizações dos grupos de judeus radicados em outros pontos das Américas, sobretudo o maior e mais consistente em termos organizacionais que é o norte-americano.

Lado a lado reuniram-se na revista uma elite intelectual brasileira e uma categoria específica, os intelectuais de origem judaica, ambas envolvidas com a condição humana e os direitos humanos. Albert Einstein ao referir-se a

\footnotetext{
${ }^{267}$ Sigmund Freud, "El Malestar en la Cultura", In: Obras Completas. Buenos Aires, Amorrortu, $2^{\mathrm{a}}$ ed., 2006, p. 88.
} 
tradição talmúdica afirmou estar associada à "busca do conhecimento por seu valor intrínseco, um quase-fanático amor pela justiça" ${ }^{\text {"268 }}$. Para a análise da especificidade deste grupo valemo-nos do conceito de judeidade e identificação presentes no estudo da psicanalista Betty B. FUKS que analisa a produção freudiana da cultura levando em conta a judeidade de seu autor. $O$ entrecruzamento de dois temas se revela em nossa abordagem: judeidade e cultura. Como judeidade entende-se "algo a ser construído, jamais terminado, mesmo que o judaísmo enquanto religião não conte para o sujeito"269. O trabalho da autora retoma a "relação entre judeu e escrita" e discute a proibição da idolatria do texto na tradição talmúdica o que "não apenas não impede o advento da palavra como a estimula"270. A proposta de Comentário é justamente a de um modelo de revista de cultura aberta que estimulava a exposição de idéias e que propunha debates.

O processo de construção da judeidade é da ordem das identificações. A judeidade como uma característica marcadamente judaica que está relacionada ao exílio e à postura do povo judeu na Diáspora, cuja coesão sempre se definiu para mais além do que pertencer a um território de origem. Este mecanismo está na própria estrutura original da revista que colocava em circulação um conjunto de questões sócio-políticas, associadas diretamente à comunidade (imaginada como idêntica, sem diferenças) e, ao mesmo tempo inseridas na cena política, econômica e cultural nacional e internacional. O fato de seus colaboradores serem atuantes e representantes das principais universidades cariocas e paulistas, judeus e não-judeus, dava ao periódico um status privilegiado na produção de um saber afinado com os problemas do seu tempo. Tempo de mudanças e inquietações políticas que aqui são consideradas enquanto elementos delineadores deste projeto editorial.

\footnotetext{
${ }^{268}$ Albert Einstein sobre aspectos da tradição judaica. In: SCLIAR, Moacyr, Se eu fosse Rothschild: citações que marcaram a trajetória do povo judeu, Porto Alegre, L\&PM, 1993, p. 139.

${ }^{269}$ Betty Fuks, Freud e a Judeidade - a vocação do exílio, Rio de Janeiro, Jorge Zahar Editora, 2000 , p. 151;

${ }^{270}$ Para o rabino Zvi Yehuda, "ouvimos tantas vezes a frase "o povo do Livro" que pensamos que ela vem de fontes judaicas. Na verdade é uma expressão de origem muçulmana. Do ponto de vista judaico, nós não somos "o povo do livro", mas um "povo de Deus"”. Ver Herbert Weiner. "A Bíblia dos Israelenses: O Sagrado e o Profano", In: Comentário, № 1, 1ํtrimestre de 1960 , p. 26.
} 
As "matrizes" liberais americanas da revista Comentário definiram uma parte significativa da finalidade do projeto na sua versão brasileira. As conseqüências desse projeto podem ser vistas na formação intelectual de uma geração de jovens judeus universitários influenciados pela valorização de estudos da língua, literatura e cultura judaicas e pelos princípios da Declaração dos Direitos Humanos, que geraram uma série de trabalhos específicos sobre exclusão, violência, minorias, racismo, etc, assuntos de ordem política, mas não ideológica ou partidária tão comuns nas décadas de 1930 e 1940 sobretudo entre os imigrantes judeus do Leste Europeu.

Este fato está associado, é claro, à delicada situação de um grupo que aprendeu com a Diáspora e integrar-se para sobreviver e do momento específico da Guerra Fria. No caso nacional, entendemos que a revista tinha por função garantir (politicamente) a pertença da comunidade enquanto presença integrada à cultura brasileira, enquanto parte dela, embora mantendo seus traços culturais próprios. "Integration without assimilation", foi uma frase que Lizette Pernidji se lembra claramente de ter ouvido durante as recepções que ela organizava ou oferecia em sua casa no Rio de Janeiro e nos jantares e eventos promovidos pelo $A J C$, dos quais participou com seu marido, diretor de Comentário e representante do AJC no Brasil, o Sr. Joseph Eskenazi Pernjidji ${ }^{271}$.

É importante ter em mente que Comentário era um produto do $A J C$, e como tal, apesar da liberdade editorial apregoada não poderia deixar de corresponder pelo menos em parte aos seus interesses. Havia uma intenção de transportar para o Brasil a promoção de estudos sobre o antissemitismo, as reflexões acadêmicas sobre o totalitarismo e a promoção da tolerância como uma característica marcadamente judaica. A ideia era evitar envolvimentos políticos que impedissem a integração com a cultura americana, ou ainda, com a cultura de países como os Estados Unidos, o Brasil e a Argentina, centros agregadores de uma parcela significativa da comunidade judaica de origem européia.

Assim, a revista passou a ser um dos meios pelos quais o $A J C$ defendia seus interesses, formando a opinião de estudantes e intelectuais e fortalecendo

${ }^{271}$ Entrevista com Lizette Pernidji concedida à Taciana Wiazovski, Rio de Janeiro, 6/04/2010. 
uma intelectualidade judaica 'antenada' com as questões políticas de seu tempo e orgulhosa de sua origem cultural judaica.

A publicação brasileira durou mais de dez anos ${ }^{272}$. Segundo Jacó Guinsburg - seu editor em São Paulo, fundador da Editora Perspectiva e professor aposentado da Escola de Comunicações e Artes da USP, a publicação brasileira tinha grande relação com a "filial" argentina ${ }^{273}$. Abrangeu toda a década de 1960 e os anos de "chumbo" da ditadura militar (até 1973) conseguindo circular em diversos estados do Brasil, apesar da vigilância e censura comuns em tempos ditatoriais.

As palavras da Sra. Lizette Pernidji, viúva do advogado e escritor Joseph Eskenazi Pernidji, repetidas vezes reproduzidas da fala dos representantes americanos do $A J C$, revelam a insistência na difusão de uma postura ativa: "Integration without assimilation"274, ou seja, integrar-se à cultura nacional, porém sem assimilar-se a ela, preservando os traços da origem judaica.

Esse assunto surge nos artigos da revista, como por exemplo, no texto de Simon Halkin a respeito da literatura hebraica moderna apontando a questão do estrangeiro no meio nacional e a sua integração. A então recente desintegração do judaísmo teve como conseqüência no romance hebraico do pós-guerra a relação de todos os aspectos do martírio judeu ao desarraigamento do judeu sem pátria. Havia que se lidar com a contradição que opõe o nacionalismo arraigado a uma consciência viva de luta de classes $^{275}$ não apenas em Israel, mas entre os judeus espalhados nos países que os receberam nas Américas.

Pode-se pensar que esse 'lema' tanto se aproxima do etnocentrismo cultural judaico na medida em que não pressupõe a assimilação, como também do universalismo militante das utopias revolucionárias que previam a exclusão de fronteiras e nações. É quase uma síntese das transformações pelas quais passou essa categoria intelectual judaica, síntese esta que representa no âmbito mais amplo da condição diaspórica judaica (não pertencer a e ao

\footnotetext{
${ }^{272}$ O número 1 é do primeiro trimestre de 1960 e o último número é do ano de 1973.

${ }^{273}$ Entrevista com Jacó Guinsburg concedida à Taciana Wiazovski, São Paulo, 11/04/2008.

${ }^{274}$ Entrevista realizada em 6/04/2010.

${ }^{275}$ Simon Halkin, "A Literatura Hebraica Moderna", In: Comentário, revista trimestral, Ano I, no 2, 1960 , p. 46 e 48.
} 
mesmo tempo pertencer), a sua própria acepção bipartite (de outro/ igual), um lema que enquanto síntese descreve o (di)lema de ser judeu.

\section{2 -Sujeito e Discurso Cultural}

A revista se revela num espaço de discursos que são registrados na forma de Comentários que nos permitem tratar a respeito do sujeito e do discurso cultural a ele correspondente. Começamos pelo artigo que inaugura a revista cujo autor, Afonso Arinos de Melo Franco, imagina a comunidade brasileira num processo complexo que a pressupõe "harmônica". Assim ele apresenta a sociedade brasileira. No entanto, a pluralidade de culturas - tais como a presença de africanos durante o período da escravidão e a maciça presença de imigrantes no Brasil - indica um provável outro caminho, na direção oposta. Projeta-se de modo que aparece o discurso de uma minoria que marca a nação, muitas vezes barrada e/ou cindida "pelas histórias heterogêneas de povos em disputa, por autoridades antagônicas e por locais tensos de diferença cultural”. ${ }^{276}$

Homi Bhabha se apropria da concepção da "divisão do eu" que revela o "sujeito do inconsciente", termo introduzido por Jaques Lacan ${ }^{277}$, para designar a hipótese do inconsciente freudiano. Onde há corte, há real e foraclusão do sujeito, há real ou o ser puro, o sujeito (do inconsciente) é outro e é lugar. Pensando o povo-nação a partir destes pressupostos Bhabha nos dirige ao local da cultura como este real, corte ou cisão, impossível de ser simbolizado, mas que prescinde de uma ideia de nação arcaica em meio às margens da modernidade, uma ambivalência que faz parte da escritura de uma nação.

Os diaspóricos representados em Comentário escrevem a sua versão da história da nação brasileira lado a lado com intelectuais ditos nacionais tendo em vista um objetivo comum: o combate ao racismo, ao antissemitismo e ao totalitarismo. O negro e o judeu nesse discurso recebem o mesmo tratamento de defesa contra a discriminação histórica. $O$ elemento totalitário se opõe à

\footnotetext{
${ }^{276}$ BHABHA, Homi K. O local da cultura. Belo Horizonte: Ed. UFMG, 1988, p. 210.

277 Cf. Pierre Kaufmann, Dicionário Enciclopédico de psicanálise, Rio de Janeiro, Jorge Zahar Ed., 1996, pp. 501-505.
} 
proposta solidária de confraternização entre os povos. Estamos diante do que Bhabha denominou de "performático", o processo de perda de identidade, perda da narrativa nacional, de estranhamento, um discurso à margem na própria narrativa nacional disseminada por todo o mundo que se pressupunha de certa forma homogênea, no sentido de se haver harmonia nas relações inter-raciais. Importante enfatizar que de 1937 até 1945, até o fim da II Guerra Mundial viveu-se sob um regime autoritário, o Estado Novo Varguista, cujas práticas de violência e exclusão de direitos e garantias individuais se contrapunham ao momento democrático em que vivia o Brasil ainda em 1960. Esse conjunto repleto de paradoxos aparece registrado nos artigos publicados em Comentário, cujo status comunitário e político representam um meio privilegiado de comentá-lo.

Debate sociológico sobre racismo

A revista foi inaugurada com 0 artigo de um homem público cujo reconhecimento social e cultural tinha potencial para Ihe conferir prestígio além de ser autor de uma lei emblemática na história da legislação brasileira sobre racismo, o que se alinha imediatamente aos seus interesses. $O$ pequeno texto de Afonso Arinos de Melo Franco ${ }^{278}$ - de família tradicional que compôs os quadros da elite nacional - está dentro da proposta da revista, na lei que ele anuncia. Em seu artigo introdutório do primeiro número da revista, Afonso Arinos exalta "a luta que o Brasil chefia contra a discriminação racial", apesar de insistir na "nossa indiscutível democracia racial". O projeto de lei que se converteu na Lei 1390 de 3 de julho de 1951 (lei Afonso Arinos) veio, segundo o autor, transferir para o campo penal a prática de ato resultante de preconceito racial, apesar de afirmar que "o problema judeu, o problema negro" haviam sido "questões artificialmente provocadas por vícios e desvios culturais dos círculos governantes, ou, no máximo, sentimentos confinados a grupos de imigrantes

\footnotetext{
${ }^{278}$ Afonso Arinos de Melo Franco, jurista, professor, político ensaísta, memorialista, historiador e crítico, autor da lei AFONSO ARINOS contra a discriminação racial (Lei 1390 de 3 de julho de 1951). Foi eleito senador em 1958 pelo antigo Distrito Federal, RJ. Ver mais a seu respeito em Anexos na tabela "Comentário: autores nacionais".
} 
estrangeiros, procedentes de países onde a discriminação se assenta nas camadas mais profundas." Essa lei veio suprir uma demanda simbólica, portanto e o acolhimento dela, segundo o seu autor, veio confirmar a convicção de que o Brasil se acha "na vanguarda da democracia racial, em todo o mundo."279

A tese da democracia racial brasileira foi defendida por Gilberto Freire em muitos de seus livros, cabendo citar aqui Casa Grande e Senzala (1933) como uma obra de grande sucesso e repercussão. Elisabeth Cancelli - no capítulo "Mal estar de civilização: a democracia e o negro no Brasil" de sua tese de livre-docência - identificou um certo mal estar que se foi instalando na cultura nacional após a II Guerra Mundial e a vitória dos Aliados sobre o nazifascismo. Esse mal estar estava no bojo do encaminhamento da política mundial em direção a dois grandes blocos políticos ideológicos: o capitalismo e - comunismo liderados pelos Estados Unidos e a União Soviética, respectivamente. Ele surgiu especificamente a partir das críticas por parte da esquerda sobre as nações que se diziam democráticas e que, no entanto, mantinham formas de racismo chegando até a segregação, como acontecia nos Estados Unidos. Estes investiram em estudos sobre os problemas raciais procurando demonstrar que a democracia os resolveria. A questão racial fazia parte dos problemas a serem superados para se poder enfrentar o comunismo e sua propaganda ${ }^{280}$.

Cancelli revela como no Brasil também a democracia haveria de "acertar as contas com o negro brasileiro" através das pesquisas financiadas pela UNESCO em 1951 e 1952 sobre as relações raciais no país. Estas pesquisas foram justificadas a partir das ideias principais de Gilberto Freire, cuja visão “ [...] enfatiza a sensibilidade de uma cultura sustentada na bondade humana ou no humanismo [... $]^{\prime 281}$. Cancelli atribui essa leitura idílica de Freyre da sociedade brasileira ao período em que o sociólogo permaneceu nos Estados Unidos em 1918 e nos anos de 1920 (Texas - Universidade de Baylor; Nova Iorque - Universidade de Columbia; visitas a Maryland e Virginia) e a uma

\footnotetext{
${ }^{279}$ Afonso Arinos, "A discriminação Racial em Face da Lei e do Sentimento Brasileiros", In: Comentário, № 1, 1ำ trimestre de 1960, pp. 7 e 8.

${ }^{280}$ Ver Elisabeth Cancelli, O Brasil e os Outros - estranhamento, humilhação, memória e política. Trabalho apresentado para Concurso de livre-docência, Departamento de História FFLCH/USP, 2008, p. 149.

281 Ídem, p. 153.
} 
influência que sofreu de um grupo de sulistas americanos denominado de Agrarians. Cabe ainda acrescentar a respeito da biografia de Gilberto Freyre e sua aproximação com os americanos, que ele completou em 1917 os estudos secundários no colégio norte-americano Gilreath de Pernambuco o que fez com que ele se transferisse para os Estados Unidos ${ }^{282}$.

Mas o grupo de pesquisadores do Programa de Pesquisa sobre Relações Raciais no Brasil, também patrocinado pela Organização das Nações Unidas para a Educação, a Ciência e a Cultura (UNESCO) era coordenado por Roger Bastide e Florestan Fernandes, cujos estudos sociológicos desenvolvidos na Universidade de São Paulo, chegaram a conclusões opostas às de Freyre afirmando que a escravidão no Nordeste gerara segregação racial e era um empecilho estrutural ao desenvolvimento do capitalismo.

A pesquisa de Florestan Fernandes se opunha completamente à tese sobre a inexistência de preconceito e discriminação em nosso país, inaugurando uma nova visão do estudo do negro, rompendo com as explicações culturalistas e conjugando questão racial, pesquisa empírica e método dialético. Segundo Cancelli, tanto a visão agrarista, sua descrença na industrialização e desenvolvimento do capitalismo e a interpretação do grupo de Florestan Fernandes noticiavam um mal estar no Brasil inserido no ambiente mundial de debate em torno da questão racial, tão estratégica para os americanos. ${ }^{283}$

Em Comentário o tema do racismo aparece em 1960 em artigo de Lúcio Costa Pinto, diretor do Centro Latino-Americano de Pesquisas Sociais adjunto à UNESCO, tratando a respeito da opessão racial na África do Sul. Assim como a situação política na África, a discriminação racial e as transformações pelas quais o continente atravessava eram analisadas tendo como pano de fundo as disputas ideológicas da Guerra Fria e o monopólio desempenhado pelos poderosos trustes conforme artigo de A. McDermott ${ }^{284}$.

O tema das relações raciais definitivamente se impôs como objeto de pesquisa sociológica e na ordem do dia. A questão racial no Brasil vinha sendo

\footnotetext{
${ }^{282}$ Dados biográficos de Freyre no DHBB disponível em http://www.fgv.br/, acesso em 20/01/2011.

${ }^{283}$ Ver Elisabeth Cancelli, Op. cit., 2008, p. 165 e dados biográficos de Florestan Fernandes no DHBB disponível em http://www.fgv.br/ acesso em 02/03/2011.

${ }^{284}$ Ver as referências desses artigos nas tabelas de autores nacionais e internacionais.
} 
tratada desde o final do século XIX a partir de múltiplas abordagens. Comentário era um veículo que dava espaço privilegiado para o assunto e para as pesquisas do Centro Latino-Americano de Pesquisas Sociais adjunto à UNESCO além de divulgar as pesquisas de Florestan Fernandes como o fez Gabriel Bolaffi no artigo "Preconceito e Grupos sociais no Brasil"285.

Neste artigo de 1960, Bolaffi argumentou contra a corrente que negava haver preconceito racial no Brasil, chamando atenção para a relação entre brancos e negros no país e incluindo os preconceitos sofridos por grupos de imigrantes como os italianos, os judeus e os poloneses. Citou a pesquisa de Florestan Fernandes patrocinada pela UNESCO que visava "conhecer através da análise de uma situação nacional os diversos fatores - econômicos, psicológicos, políticos e culturais que influem no sentido da harmonia ou desarmonia nas relações de raça. ${ }^{286 " . ~}$

Em $1961^{287}$ Bolaffi escreveu uma resenha do livro Mudanças Sociais no Brasil (1960) de Florestan Fernandes ${ }^{288}$, novamente tratando da obra científica de Florestan Fernandes e sua nova perspectiva das ciências sociais no Brasil. Em 1962, na seção "Bibliografia" comentou a monografia de Octavio lanni, então publicada sob o título de As Metamorfoses do $E s c r a v{ }^{289}$, elogiando a abordagem dialética marxista "controvertida" afirmando tratar-se "de um esforço de fazer da Sociologia, sem partir de prenoções, uma ciência militante a serviço do homem" 290 .

A escritora e jornalista Yvonne Jean também escreveu sobre a UNESCO para Comentário a respeito do racismo a partir do número de outubro de 1960 da revista mensal daquela instituição nomeada de Le Courrier que saía simultaneamente em diversos idiomas: francês, espanhol, inglês, russo, alemão, árabe e japonês. Aquele número surgiu em virtude das manifestações antissemitas na Alemanha e em diversos países, além da divulgação das medidas discriminatórias contra os negros na África do Sul. Yvonne Jean tratou

\footnotetext{
${ }^{285}$ Gabriel Bolaffi, "Preconceito e grupos sociais no Brasil”, In: Comentário, Ano I, no. 4, out-novdez, 1960.

${ }_{286}$ Ídem, p. 25.

${ }^{287}$ Ídem, pp. 91-92.

${ }^{288}$ Da coleção "Corpo e Alma do Brasil" dirigida por Fernando Henrique Cardoso que tinha por objetivo de embora especializada, voltar-se para o grande público

${ }^{289}$ Também da coleção "Corpo e Alma do Brasil".

${ }^{290}$ Gabriel Bolaffi, "As Metamorfoses do escravo", seção "Bibliografia", In: Comentário, Ano III, no. 4, out-nov-dez, 1962, p. 379.
} 
da campanha antirracista desenvolvida pela UNESCO desde 1950 quando a "Conferência Geral da UNESCO encarregou o Secretariado da organização de elaborar farta documentação científica sobre a questão racial, dando ampla difusão aos estudos realizados, publicando-os em folhetos e reunindo os folhetos mais importantes em coletâneas". Daí o surgimento de "diversos inquéritos sobre o conceito de raça e a situação das raças em diversas regiões". Foi a partir dessa iniciativa que se desenvolveram os estudos sobre 0 problema das raças e classes no Brasil. No artigo a jornalista faz um resumo dos principais textos publicados na revista enfatizando "o fenômeno" do antissemitismo e a necessidade de se educar os indivíduos e os povos. ${ }^{291}$.

Voltando ao discurso presente no artigo de Afonso Arinos notamos que ele simplesmente reafirma o mito da democracia racial através de um político herdeiro de uma tradicional família de políticos e intelectuais brasileiros, e que criou uma lei segundo a qual o preconceito racial passa a representar uma infração de âmbito penal. Não se pode dissociar o senador, o político, seu papel do seu discurso. O racismo estava na ordem do dia e uma lei ainda que "preventiva" servia como meio e garantia de visibilidade política.

As décadas de 1950 e 1960 foram caracterizadas por homenagens, doutoramentos e premiações a Gilberto Freire e sua obra por todo o mundo. Conferencista convidado pelas principais universidades mundiais, a visibilidade de Gilberto Freire enquanto sociólogo era internacional, bem como a sua participação em eventos que envolvesse temas culturais. Assim foi em 1949 na Assembléia Geral da Organização das Nações Unidas (ONU), como membro da Comissão Social e Cultural e representante do Brasil, ou no ano seguinte quando participou do Conclave dos Oito, uma conferência convocada pela ONU para a Educação, a Ciência e a Cultura (UNESCO), enquanto um dos oito especialistas mundiais em "ciências do homem". Gilberto Freire era uma referência mundial em sociologia e antropologia.

Existe um ponto de tensão na versão do político Afonso Arinos a respeito da questão racial, paradigmática da construção da identidade brasileira, uma vez que persistia na revista enquanto programa o combate ao

\footnotetext{
291 Yvonne Jean, “A UNESCO e o Preconceito Racial”, In: Comentário, Ano II, no. 3, jul-ago-set, 1961, pp. 275-281.
} 
racismo. Os modos pelos quais o periódico e seus colaboradores se colocavam a esse respeito era assunto central da revista envolvendo uma postura de militância. O ponto de tensão talvez se encontre no discurso (na palavra) do político que não sustenta bases históricas nacionais e demanda social suficiente para provocar o estabelecimento de uma lei, um discurso muito de acordo com as teses de Gilberto Freire a respeito da relação harmoniosa cordial entre senhores e escravos no Brasil. A lei, no entanto, foi feita e ainda elaborada prevendo prisão e multa, mas "apenas para garantir uma norma ética” presente na liberal-democrática Constituição Brasileira de 1946 que, no Artigo 141, parágrafo quinto, possuía um trecho que "proíbe, dentre as manifestações do pensamento 'a propaganda de preconceitos de raça'” 292.

Não temos a pretensão de aqui analisar juridicamente o amplo conceito de norma jurídica e sua complexa função. Entendemos estar a mentalidade a respeito da questão racial descrita acima calcada na experiência antidemocrática associada aos eventos relacionados ao período da Segunda Guerra Mundial e ao posicionamento do Estado brasileiro ao lado dos Aliados apartir de 1942. A norma, neste caso, não reflete a mentalidade das classes dirigentes, representadas pelo discurso de Afonso Arinos que não percebe desigualdades de relações raciais na sociedade brasileira, sustentado "cientificamente" pela perspectiva freireana, mas, se estabelece enquanto "um dever-ser da conduta" ${ }^{293}$. Segundo Leon Frejda Sclarowsky, advogado e subprocurador da Fazenda Nacional aposentado, tratava-se mesmo de uma lei "de duvidosa aplicação e com efeitos meramente simbólicos, por tratar a matéria como contravenção, com penas reduzidíssimas"294.

O que se percebe nesse emblemático artigo é, portanto, a palavra que escapa e responde a ideia subjacente da não necessidade de uma revista de combate ao racismo e antissemitismo no Brasil, já que estes são tidos como questões pontuais numa narrativa nacional que envolve uma generalização do social em nome de uma nacionalidade não vista como unificadora, como as

\footnotetext{
${ }^{292}$ Afonso Arinos, "A discriminação Racial em Face da Lei e do Sentimento Brasileiros", In: Comentário, № 1, 1ํㅡㄹ trimestre de 1960, p 8.

${ }^{293}$ Sobre o conceito de norma jurídica ver FERRAZ JUNIOR, Tercio Sampaio. Introdução ao estudo do direito - técnica, decisão, dominação. São Paulo, Atlas, 1988, p. 101.

${ }^{294}$ Ver artigo de SKLAROWSKY, Leon Frtejda, "Crimes de Racismo - Crimes resultantes de discriminação ou preconceito de raça, cor, etnia, religião ou procedência nacional", disponível em http://www.movimentoafro.amazonida.com/crimes de racismo.htm, acessado em 21/01/2011.
} 
nacionalidades européias (na "leitura pedagógica" ou "sem diferenças" que Bhabha destaca), mas, em substituição a isso, "harmônica", respondendo do mesmo modo aos anseios da classe dirigente ou dos grupos dominantes.

O jurista e também político Prado Kelly, tal qual Afonso Arinos, pertencia ao grupo dos que afirmavam não existir preconceito racial no Brasil. Para ele, "a resistência, no Brasil, a qualquer preconceito racial foi antes a obra dos costumes que das leis." Além disso, remetendo-se à "vasta bibliografia", citando os "cruzamentos raciais" e a população mestiça afirmou que inexistiam nas classes dirigentes, "resíduos doutrinários que, em outros países, alimentaram a presunção, mais política do que obscurantista, da superioridade ariana". A Lei Afonso Arinos teria sido elaborada por "excesso de zelo", não havendo resquício de intolerância no Brasil, segundo o jurista. A lei teria função educativa e seria fruto dos princípios ideais proclamados através da “Declaração Universal dos Direitos Humanos" de 1948 da ONU 295.

Outro autor, seguindo essa mesma imagem da nação brasileira, Napoleão L. Teixeira - catedrático de Medicina Legal da Faculdade de Direito e da Clínica Psiquiátrica da Faculdade de Medicina, ambas da Universidade do Paraná - ao tratar do complexo de inferioridade, o atribuiu, entre outras razões à influência de uma inferioridade real, orgânica ou psicológica, citando como exemplo os casos daqueles que "são alvos de preconceitos de raça, cor ou religião, nos países em que estes existem (e, felizmente, nosso Brasil não é um deles)"296. O professor de Economia Ovidio da Cunha em seu artigo "Perspectivas de Atualização das Estruturas Sociais nas sociedades subdesenvolvidas" afirmou haver uma "predisposição biológica ao tropicalismo" por parte do colonizador ibérico que concorreu para a democracia racial e para a unidade nacional.

A ONU, a UNESCO e o documento da Declaração dos Direitos Humanos eram parâmetros a partir dos quais se posicionavam a comunidade jurídica internacional e os principais pensadores do país no período. Estes eram consideravelmente representados na revista Comentário, que publicava artigos lembrando a universalidade do documento citado e a necessidade de se

\footnotetext{
${ }^{295}$ Prado Kelly, "O Preconceito Racial e as Declarações de Direito do Homem", In: Comentário, № 4, 4ํㅡㄴ trimestre de 1960, pp. 21-23.

${ }^{296}$ Cf. Napoleão L. Teixeira". Aspectos do Complexo de Inferioridade", In: Comentário, N. 2, ANO V, 1964, pp. 138-148.
} 
educar os povos ${ }^{297}$. Desso modo a revista serviu de espaço às vozes do debate que colocou o Brasil ora ao lado dos países democráticos com histórico de segregação racial ora como um país

\begin{abstract}
"indicado para se colocar na vanguarda de uma campanha anti-racista, já que como declara o cientista americano Charles Wagley, 'este país é um exemplo: nesta nação oriunda de cruzamentos entre três grupos raciais diferentes, composta de descendentes de escravos e senhores, nasceu uma sociedade, que, nas relações entre indivíduos, coloca os valores humanos e sociais antes das questões de 'raça'", ${ }^{298}$
\end{abstract}

No Brasil, por influência americana, vingou a ideia de racismo que irá alimentar medidas de ação afirmativa, como, por exemplo, as cotas para negros, algumas décadas depois. Assunto extremamente polêmico nos dias de hoje e sequer resolvido.

Entendimento entre judeus e cristãos

O Instituto Brasileiro Judaico de Cultura e Divulgação (IBJCD) promoveu a aproximação do grupo intelectual judaico a grupos intelectuais de destaque nacional e influência política e junto à grande imprensa, entre os quais citamos, por exemplo, os herdeiros e líderes do movimento reacionário católico da década de 1930. Tanto que publicou o livro de Jacques Maritain e Padre Riquet intitulado $O$ Cristão diante do Anti-semitismo, a fim de remover os mitos antijudaicos difundidos pela Igreja Católica ao longo de séculos ${ }^{299}$. Na seção "Registro" do primeiro número da revista foi publicado um artigo sobre Alceu Amoroso Lima, que acabava de ganhar o "Prêmio Moinho Santista 1959". Alceu Amoroso Lima desde o início da década de 1940 vinha revendo suas posições mais conservadoras. Ele acabou lutando pela redemocratização do país em 1945 e destacou-se enquanto um líder católico que defendia a

\footnotetext{
${ }^{297}$ René Cassin, "Como lograr um mundo melhor", In: Comentário, n. 4, ano II, 1961, pp. 357363.

${ }^{298}$ Yvonne Jean, "A UNESCO e o Preconceito Racial”, In: Comentário, Ano II, no. 3, jul-ago-set, 1961 , p. 281.

${ }^{299}$ Cf. Lista de publicações do IBJCD In: Comentário, ano II, n. 4, 1961, p. 378.
} 
democracia cristã ${ }^{300}$. Conhecido na América e na Europa acabava de voltar dos Estados Unidos onde dera um curso de civilização brasileira a convite da New York University.

Comentário publicou um artigo de Barreto Filho ${ }^{301}$ a respeito da realidade americana interpretada pelo intelectual católico francês Jacques Maritain no período em que lá morou (1940-1960), tendo sido obrigado a deixar a França em virtude da origem judaica de sua mulher Raissa. Segundo Barreto Filho, Maritain identificava uma vocação moral na sociedade americana em virtude de um legado cristão, admirava seus institutos de caridade e via na civilização americana uma grande promessa para o gênero humano apontando entre os pontos vulneráveis o problema da segregação racial e "a ansiedade de serem amados pelos outros. ${ }^{302 " ~ A ~ c u l t u r a ~ a m e r i c a n a ~ a i n d a ~ e ́ ~ r e t r a t a d a ~ n a ~}$ revista a través de artigos reproduzidos de Commentary, sobre religião, por exemplo, como escreve o professor de filosofia Will Herberg.

A partir da década de 1950, a pátria da intelectualidade brasileira que antes era a França passou a ter os Estados Unidos como uma grande referência. $\mathrm{O}$ artigo de Gladstone Chaves de Melo a respeito de Alceu Amoroso Lima descreveu como parte de sua "personalidade espiritual" o fato de este reprovar "como desumano e anticristão, o anti-semitismo, como qualquer outra forma de discriminação racial, política ou religiosa" ${ }^{303}$. Vale notar que a revista A Ordem criada por Jackson de Figueredo em 1922 e dirigida a partir de sua morte em 1928 por Alceu Amoroso Lima, foi uma das porta-vozes do antissemitismo entre outros veículos de comunicação católicos da chamada "Boa Imprensa" por meio da difusão do mito do complô judaico-comunista, entre as décadas de 1920-1940 304 . O grupo de pensadores católicos manteve

\footnotetext{
${ }^{300}$ A respeito de Alceu Amoroso Lima foi consultado o verbete com o seu nome no DHBB, www.fgv.br, acesso em 21/02/2011.

${ }^{301}$ José Barreto Filho (1908-1983) foi filósofo, ensaísta, poeta, romancista, crítico literário, educador, advogado e político. Ligado ao círculo de amigos e de intelectuais vinculados ao pensamento de Jackson de Figueiredo do movimento reacionário católico ou de renovação católica. Ver mais detalhes na tabela de Autores Nacionais em "Anexos".

302 "Realidade norte-americana vista por Maritain", In: Comentário, Ano I, n. 1, 1960, pp. 50-53 (resenha da obra Reflexões sobre os Estados Unidos de Jacques Maritain. Rio de Janeiro, Editôra Fundo de Cultura, a respeito da sociedade e política estadunidense).

${ }^{303}$ Gladstone Chaves de Melo, "Alceu Amoroso Lima, o Laureado do Ano", In: Comentário, Ano I, ํㅡ 1, 1960, p 83.

304 Cf. Taciana Wiazovski. O Mito do Complô Judaico-Comunista: Gênese, Difusão e Desdobramentos (1907-1954). São Paulo: Humanitas, 2008. Originalmente apresentada como Dissertação de mestrado, FFLCH, USP, Depto de Letras Orientais, 2005, pp. 53-149.
} 
representação na revista Comentário ainda com artigos de autores como Gustavo Corção, José Barreto Filho e do próprio Alceu Amoroso Lima que escreveu a respeito do católico militante e reacionário Eduardo Prado. Alceu Amoroso Lima (Tristão de Athaíde) em abril de 1965 discursou em São Paulo por ocasião da memória da revolta do Guetto de Varsóvia ${ }^{305}$.

Assim, pode-se afirmar que no Brasil ao menos, ampliando de modo geral ao Ocidente, no início do século XX até o fim da Segunda Guerra Mundial, a pátria intelectual dos católicos do movimento reacionário era a França e os inimigos o Positivismo, a República, a Maçonaria, o Comunismo, o Liberalismo, a Revolução Francesa, o Marxismo, a "Má Imprensa" (judaica, para esse grupo de pensadores católicos), os Judeus, o Ateísmo, o Espiritismo, o Protestantismo, entre outros. As associações livremente se faziam: "judaísmo maçônico", "judeu sem pátria”, "positivismo sem Deus”, configurando-se uma livre-associação de indesejáveis ${ }^{306}$.

Após a Segunda Guerra Mundial, e sempre seguindo os ditames do Vaticano, a Igreja procurou aproximar-se dos valores humanitários e democráticos, diretamente identificados aos Estados Unidos, e afastar-se de qualquer relação com o nazismo que ocupava o "pólo do mal" tendo sido os judeus as suas especiais vítimas. A revista registrou 0 estreitar desse relacionamento que se deu através da ida freqüente da elite intelectual católica, inclusive brasileira, aos Estados Unidos e de livros e artigos publicados por eles elogiando a sociedade, política e valores norte-americanos. Alguns inimigos católicos foram passando para o lado de agora 'amigos'. No que concerne aos judeus, era de interesse do grupo que os mitos antijudaicos que haviam sido propagados durante séculos pela Igreja católica caíssem por terra de uma vez por todas eliminando talvez a principal fonte do antissemitismo. Uma postura vinda do Vaticano se fazia imperiosa.

O Concílio Ecumênico realizado entre 11de outubro de 1962 e 8 de dezembro de 1965 no Vaticano, sob o pontificado de João XXIII e Paulo VI apareceu em diversos artigos da revista tendo recebido ampla cobertura da

\footnotetext{
${ }^{305}$ Cf. Alfred Hirschberg "Brasil", Foreign Coutries: Latin America, American Jewish Year Book (AJYB), Vol. 67, 1966, p. 298. In: http://www.ajcarchives.org/AJC DATA/Files/1962 16 LatinAmerica.pdf, acesso em 13/04/2011. 306 ídem.
} 
imprensa de um modo geral, sobretudo durante a sessão final daquele evento. Naquele momento, de acordo com Alfred Hirschberg [para o American Jewish Year Book (AJYB)], a comunidade judaica esteve em constante contato com líderes católicos. Desse modo, em São Paulo, o Rabino Fritz Pinkuss recebeu a visita do Cardeal Dom Agnelo Rossi, nomeado presidente honorário do Conselho de Fraternidade Cristão-Judaica, antes dele ir a Roma. Na volta o rabino foi visitá-lo. A Federação do Rio de Janeiro se encontrou com o cardeal Dom Jaime de Barros Câmara em fevereiro de 1965. Em agosto do mesmo ano o Cardeal agradeceu publicamente os judeus pela contribuição na contrução da Catedral na área central do Rio de Janeiro. O Rabino Fritz Pinkuss foi o representante da comunidade israelita em um Colóquio interreligioso a respeito de "Verdade e Vida" em São Paulo. ${ }^{307}$

O artigo "O Concílio Ecumênico e os Judeus" de Arthur Gilbert publicado em Comentário em $1962^{308}$ fez uma espécie de "retomada", das condenações e mitos antijudaicos católicos, apresentando em certa medida uma "nova atmosfera" no sentido de uma aproximação entre judeus e cristãos, incluindo os mesmos inimigos classificados como ameaças à democracia: o "comunismo ateu" associado à "tirania" ou ao totalitarismo, o "Islão militante", "um mundo revolucionário" (p. 201). O texto assinalou como as raízes cristãs do antissemitismo depois do nazismo passaram a ser motivo de vergonha para os católicos (p. 208). Na lógica desse novo mundo as perseguições católicas sofridas pelos judeus durante séculos deveriam sofrer condenações veementes.

Aos poucos a lgreja foi se colocando, fazendo declarações contra o antissemitismo, revendo a parte relacionada aos judeus na liturgia, propondo o ecumenismo, mas o que o autor esperava - conforme escreveu no artigo publicado originalmente em The Reconstructionist, uma publicação religiosa judaica - era a redenção que deveria ocorrer durante o XXI Concílio Ecumênico que então estava por acontecer, através de uma denúncia categórica de toda a

\footnotetext{
${ }^{307}$ Cf. Alfred Hirschberg "Brasil", Foreign Coutries: Latin America, American Jewish Year Book (AJYB), Vol. 67, 1966, p. 298. In: http://www.ajcarchives.org/AJC DATA/Files/1962 16 LatinAmerica.pdf, acesso em $13 / 04 / 2011$

${ }^{308}$ Ver referência em na tabela de Autores Nacionais em "Anexos".
} 
forma de intolerância racial e religiosa, um apoio enfático à liberdade religiosa além do reconhecimento oficial do Estado de Israel por parte da Igreja.

Logo depois do artigo de Gilbert Comentário publicou um inquérito em defesa da democracia, prosseguindo nesse formato de debate que vinha fazendo. O já citado e um dos líderes do Partido Democrata Cristão, Gladstone de Oliveira, respondeu às perguntas, além de João Mangabeira, ex-senador, jornalista, conferencista e conhecido por "seus princípios dentro da linha socialista" ${ }^{309}$.

Desde a promulgação da Declaração Universal dos direitos da Pessoa Humana em 10 de dezembro de 1948 pela Terceira Assembléia Geral da Oganização das Nações Unidas, muitas modificações vinham ocorrendo. Assim, em 1954, o presidente Jânio Quadro mandara tirar dos dicionários os significados pejorativos das palavras "judeus" e "Judas" e o Papa João XXIII havia suprimido da oração litúrgica o adjetivo "pérfidos" que qualificava os judeus $^{310}$. Estas atitudes se relacionavam a uma postura global vinculada aos chamados Direitos Humanos e às excelentes relações diplomáticas entre Brasil e Israel ${ }^{311}$. Em 1965, na Terceira Assembléia Geral da ONU (questões sociais, humanitárias e culturais), onde foi debatido um projeto de Convenção Internacional sobre a Eliminação de todas as formas de Discriminação Racial, Brasil e Estados Unidos introduziram uma emenda que previa a condenação específica do antissemitismo pelas partes no tratado, além de se tomar medidas para a rápida erradicação nos territórios sob a sua jurisdição ${ }^{312}$.

\footnotetext{
${ }^{309}$ Cf. "A defesa da Democracia - um inquérito", In: Comentário, ano III, n. 3, 1962, pp. 210 212.

${ }^{310}$ Cf. o artigo do Padre Bertrand de Margerir S. J., então Diretor do Departamento de Formação de Vocações da Conferência dos Religiosos do Brasil, "Os Judeus na Catequese e nos missais do Brasil", In: Comentário, ANO v, N. 1, 1964, p. 63.

${ }^{311}$ Em 1965, no seu discurso de abertura no Colóquio da Organization of American States (OAS) no Rio de Janeiro em novembro, o Presidente Castelo Branco se referiu apenas a Israel como um país que teria fornecido ao Brasil real assistência técnica agrícola, resultando no plantio de trigo na Bahia com o auxílio de consultores técnicos israelenses, dentro do Programa Aliança para o Progresso atuando junto com a Superintendência de Desenvolvimento do Nordeste (SUDENE). Havia uma ativa troca cultural a científica entre os dois países. Cf. Alfred Hirschberg "Brasil", Foreign Coutries: Latin America, American Jewish Year Book (AJYB), Vol. 67, 1966, p. 304. In: http://www.ajcarchives.org/AJC DATA/Files/1966 8 LatAmerica.pdf, acesso em 13/04/2011.

${ }^{312}$ Cf. George E. Gruen, "Nazism, Zionism, Antisemitism - The United Nations and the ArabIsrael Dispute - United States, Israel and The Middle East", United States: Communal, American Jewish Year Book (AJYB), Vol. 67, 1966, p. 263. In:

http://www.ajcarchives.org/AJC DATA/Files/1966 6 USCommunal.pdf, acesso em 14/04/2011.
} 
Os Direitos Humanos foram abordados pelo Cardeal-Arcebispo de Santiago do Chile enquanto parâmetro, no artigo "Direitos Humanos no Antigo Testamento" de Raul Silva Henriquez, publicado em 1966 ${ }^{313}$. Assim Comentário atuava enquanto propagadora das ideias capazes de promover a aproximação entre judeus e cristãos.

3.3 - Mais ainda sobre o que se escrevia

No periódico Comentário se avolumam artigos que retratam a influência da perspectiva das ciências sociais norte-americanas tendo como eixo central os campos temáticos dos direitos civis, racismo, etnicidade, imigração, antissemitismo, religião, democracia, capitalismo e a revisão do comunismo a partir do descontentamento com 0 stalinismo. O conjunto conceitual psicanalítico ao lado da antropologia cultural e da sociologia - todos em voga na época - foi aplicado por muitos intelectuais na resolução das questões que se impunham incessantemente na década de 1960 em torno dos eixos temáticos citados.

Antissemitismo, Psicologia Social e Ciência

A partir do ano de 1962 a revista passou a anunciar algumas publicações do IBJCD, entre elas, um trabalho intitulado "A Ciência pesquisa o Antissemitismo". O propósito de se aprofundar a respeito do antissemitismo tendo por escopo combatê-lo está claro na revista como parte das ações do $A J C^{314}$.

A psicanálise, a biografia e a obra do alemão Erich Fromm, um dos intelectuais judeus analisados por Michael Lowy, citado no primeiro capítulo deste trabalho, foram abordados pelo Tenente-Coronel Octavio Alves Velho,

\footnotetext{
${ }^{313}$ Cardeal Raul Silva Henriquez, "Direitos Humanos no Antigo Testamento", In: Comentário, Ano VII, n. 1, 1966, pp. 33-38.

${ }^{314}$ Cf. In: Comentário, Ano III, n. 4, 1962, p. 379.
} 
antigo professor de Português da Academia Militar de West Point, descrito como "um dos maiores conhecedores da obra do psicólogo", que sintetizou traços da obra de Fromm, escreveu uma breve biografia sua e citou principais obras $^{315}$. Fromm examinou os sistemas totalitários, a psicologia do nazismo, escreveu sobre a linguagem simbólica, a personalidade e as influências culturais, entre outras ideias. Octavio Alves Velho no número 3 da revista de 1961 escreveu uma resenha a respeito de dois livros de Erich Fromm, entre os quais destacamos Marx's concept of man onde Fromm afirmou que a União Soviética era um sistema do capitalismo de Estado conservador e não a realização do marxismo socialista, além de ter enunciado que o ocidente tinha muito a oferecer como líder, em virtude de sua tradição de dignidade e fraternidade humanas ${ }^{316}$. Essas afirmações de Fromm são representativas da argumentação que levou o intelectual judeu de esquerda a se aproximar dos valores liberais americanos.

Em artigo de 1962, Eliezer Schneider baseou-se em Fromm ${ }^{317}$ por meio do estabelecimento de uma relação entre certas características da personalidade com atitudes sociais e políticas determinadas para desenvolver seu artigo intitulado "Autoritários, anti-semitas e liberticidas". Essa fundamentação das pesquisas sócio-psicológicas que foram financiadas pelo AJC conforme já tratado no primeiro capítulo, serviu para gerar um discurso científico, portanto com caráter de verdade, para relacionar a personalidade autoritária ao fascismo e ao comunismo, distanciando-a dos que defendiam a democracia, o liberalismo ou eram apolíticos. Tornar-se um antissemita a partir de uma personalidade autoritária seria um caminho curto e natural. Essas pesquisas associadas a outros argumentos (expurgos stalinistas) mostram a construção do raciocínio que foi levando os intelectuais judeus, de um modo geral, a se afastarem pouco a pouco do comunismo. ${ }^{318}$

\footnotetext{
${ }^{315}$ Octavio Alves Velho, “Erich Fromm e a Psicanálise”, In: Comentário, № 1, ANO II, 1961, pp. 47-51.

${ }^{316}$ Octavio Alves Velho, resenha de Marx's concepto of man de Erich Fromm, London, 1961, In: Comentário, № 3, ANO II, 1961, pp. 287-288.

${ }^{317}$ As obras de Erich Fromm serviram como referência teórica psicanalítica para muitos autores que colaboraram em In: Comentário. Um exemplo é o artigo do antropólogo Roberto da Matta "Edgar Allan Poe, o 'bricoleur': um exercício em análise simbólica" que analisou o conto "Gato Preto" de Poe atribuindo à obra do autor uma construção de caráter antropológico estruturalista. Para desenvolver essa ideia valeu-se do trabalho de Lévi-Strauss, que passava a usar o termo estruturalismo. In: Comentário, Ano, VI, n. 3, 1965, pp. 236-246.

${ }^{318}$ Ver cada autor e referência de artigo citado nas Tabelas de Autores.
} 
O artigo de Selma Fraiberg "A Ciência do Contrôle Mental" a partir dessa linha de produzir uma psicologia científica da tirania estudou o processo de escravização mental e a fidelidade mórbida de um homem a seus perseguidores onde estabeleceu uma aproximação entre estudos sobre 0 comportamento individual e coletivo na sociedade do campo de concentração aos dos acusados nos Julgamentos de Moscou e aos prisioneiros repatriados da guerra coreana de modo a avaliar as técnicas de confissão e de reeducação dos comunistas chineses (lavagem cerebral).

Em "Visão Geral da Psicologia” o médico Emilio Mira y Lopez faz uma espécie de definição do campo concluindo a partir da metáfora do corpo que a fórmula de se "obter a mais sadia e eficiente integração das células individuais no Grande Organismo da Humanidade" estaria num trabalho a ser desenvolvido pela Psicologia voltado aos "grandes problemas da comunicação e a conveniência coletivas", colaborando no desparecimento "das guerras e das revoluções" na atenuação dos delitos, vícios, sofrimentos e neuroses.

O interesse pela psicologia, dado o seu constante aparecimento em Comentário revela uma aposta de que através desse campo do conhecimento se pudesse chegar a uma integração - palavra de ordem depois dos traumas de guerra - entre as pessoas do mundo todo. Um caminho de transformação do "Vale de Lágrimas" em direção a um "Vale de Paz, Trabalho e Felicidade".

O judaísmo da revista

No que se refere ao "judaísmo" da revista americana, Ruth W. Wisse afirmou que este promoveu o neoconservadorismo antes mesmo que o termo viesse a ser usado. A defesa de Israel, segundo a autora, tornou-se o motor da inclinação conservadora a partir da década de 1960 e muito antes da Guerra dos Seis Dias em 1967, em virtude da ameaça de desaparecer que aquele Estado que sofreu desde sua criação ${ }^{319}$. Assim, a temática da experiência de um Lar Nacional Judaico e suas implicações culturais foi retratada na revista

\footnotetext{
${ }^{319}$ Ruth R. Wisse. "The Jewishness of Commentary", In: FRIEDMAN, Murray (editor), Op. Cit., 2005, pp. 67.
} 
brasileira em diversos artigos reproduzidos da revista Commentary, como "A Bíblia dos Israelenses" de autoria de Herbert Weiner, rabino e ensaísta norteamericano. Weiner tal como outros rabinos reformistas que apareciam em Commentary criticava o Judaísmo liberal tanto quanto os rabinos associados ao movimento conservador ${ }^{320}$. Nesse artigo analisa o significado da Bíblia em Israel naqueles dias, profetizando uma "absorção do profano pelo sagrado" 321 . Em "Israel e o Judaísmo", Shaul Levin tentou responder se existia uma cultura israelense particular destacada da cultura judaica geral em 1964. Em sua negativa previa uma integração em vinte anos de todas as tradições judaicas o que chamou de "pan-judaísmo" ${ }^{322}$.

A religião, história, literatura e filosofia judaicas eram abordadas em Comentário através de artigos traduzidos de Commentary por especialistas como: Abraham Joshua Heschel, Simon Halkin, Ch. W. Reines, Samuel S. Cohen, Will Herberg, Immanuel Lewy, Leo S. Baeck, Louis Filkenstein, Jehezkel Kaufman, A. Alan Steinbach, Emil L. Fackenheim, Jacob J. Petuchowski, Eugene B. Borowitz. ${ }^{323}$. A importância dos artigos sobre a tradição judaica literária foi se estabelecendo na medida em que esses autores (norte-americanos na sua grande maioria) escreviam.

Com subsídios do judaísmo o rabino de Nova lorque A. Alan Steinbach escreveu "Democracia: a Medida do Homem", como sendo a democracia uma "solução aceitável para a vida humana", criticando "o empedernido descaso com a vida e a dignidade humanas" da Rússia Soviética, da China Comunista, de Cuba e da Alemanha Oriental, ou seja, de "todos os países em que a foice e o martelo são o signo". O ateísmo associado ao comunismo foi alvo de ataques por parte dos religiosos que viam no "materialismo ateu" uma fonte "que degrada a trunca o homem e o torna um boneco à mercê de ditadores inescrupulosos e cruéis". Steinbach de forma progressiva analisou quatro revoluções do pensamento tecendo críticas a cada uma delas. Após criticar o materialismo de Marx como representante da revolução econômica, o rabino

\footnotetext{
${ }^{320}$ Idem, p. 66.

${ }^{321}$ Herbert Weiner, A Bíblia dos Israelenses - O Sagrado e o Profano", In: Comentário, 1960, n. 1 , ano I, p. 33.

${ }_{322}$ As referências biográficas e de artigos publicados na revista estão nas tabelas em "Anexos". 323 ídem.
} 
tratou da revolução biológica nas suas conseqüências, a exemplo da produção das teorias raciais que geraram políticas racistas como as de Hitler.

Para Steinbach a psicanálise de Freud, responsável pela revolução psicológica, deveria se reconciliar com a religião. Foi na revolução política através da democracia que o religioso viu a "medida do homem" na sua defesa da dignidade humana ${ }^{324}$. Artigos de religiosos como Steinbach, demonstram a afirmação de Ruth $R$. Wisse a respeito dos intelectuais conservadores de Commentary, os quais "assumiram que na civilização judaica e na democracia americana, a autoridade constituída agiu a seu favor"325.

No Brasil, Henriqeu Lemle, rabino da ARI e o escritor e crítico literário Anatol Rosenfeld escrevia sobre judaísmo porém em nada se aproximavam dessa perspectiva conservadora norte-america.

Da presença da história judaica na revista Comentário destacamos os artigos dos historiadores Cecil Roth e Salo W. Baron, reproduzidos de Commentary. Entre eles, de Cecil Roth: "Os manuscritos do Mar Morto Chaves para uma época" e "Simão Bar Giora, Herói Judeu". De Baron: "Novas Tônicas na História Judaica" e ainda o estudo etnográfico de Wolf Leslau: "Os Judeus Pretos da Etiópia”, de judaísmo anterior a Mishná e o Talmude. De Hans Borger: "Antecedentes da Revolta dos Macabeus", entre outros.

Entre os autores brasileiros, a história judaica nas Américas passou a ser abordada como, por exemplo, no texto de Mário Barata que, apesar de crítico de arte, escreveu sobre a nação judaico-portuguesa no Suriname como um exemplo de convivência e tolerância social e religiosa do século XVIII e até aquele momento ${ }^{326}$.

O sionismo, por sua vez, apareceu na revista de diversas formas: por meio da reflexão sobre a fé de Israel e sua natureza nacional no âmbito da

\footnotetext{
${ }^{324}$ Cf. A. Alan Steinbach, “Democracia: a medida do homem”, In: Comentário, Ano VI, n. 2, 1965, pp. 110-114.

325 "Intelectuais Conservadores não buscaram liberdade ou independende da autoridade constituída: eles assumiram que na civilização judaica e na democracia americana, a autoridade constituída agiu a seu favor (Conserative intellectuals did not seek freedom or independende from constituted authority: they assumed that in jewish civilization and american democracy, constituted authority acted on their behalf). Ruth R. Wisse. "The Jewishness of Commentary", In: FRIEDMAN, Murray (editor), Op. Cit., 2005, p. 70.

326 "'Nação Judaico-portuguesa' do Suriname e suas relações com o Brasil, no século XVIII", In: Comentário, revista trimestral, Ano I, №. 1, 1960, pp. 54-57.
} 
filosofia $^{327}$ e através de artigos de colaboradores, por exemplo, da revista sionista Midstream freqüentes em Comentário. Entre os colaboradores de Midstream que colaboraram em COMMENTARY citamos: Nissim Rejwan, redator do jornal árabe Al-Yaun e membro da redação do Jerusalém Post. ${ }^{328}$

$O$ ressurgimento de uma língua e todo esforço empreendido para tanto foi alvo do artigo de Hal Lehrman em "Uma Língua Volta à Vida" de 1961. O kibutz, a política, e as relações internacionais de Israel também receberam espaço privilegiado e eram comentadam por jornalistas tais como A. V. Sherman e especialistas como Leo Kohn e Joan Desser ${ }^{329}$.

O rabino Fritz Pinkuss, entre outros, escreveu sobre a migração judaica ${ }^{330}$ e os jornalistas Paul de Pally e Yoel Kechet abordaram a questão dos refugiados árabes. Paul de Pally lembrou a respeito da "responsabilidade dos países árabes pela perseguição, desapropriação de bens e expulsão de quase meio milhão de judeus, que Israel teve de abrigar" e o segundo, mostrou as teses em disputa a respeito do então recente debate sobre os refugiados árabes, ocorrido nas Nações Unidas.

Ainda no mundo árabe, esteve presente o nasserismo no Egito com depoimentos do intelectual socialista português Paulo de Castro (que havia defendido Nasser contra Bem Gurion em 1956) e artigo do israelense Meir Grossman. Elias Cooper tratou da política nazista no Oriente Médio e a relação de Hitler com o Mufti de Jerusalém, enquanto que Henri Siegman analisou as relações entre as comunidades árabe e judaica, identificando a origem das tensões entre "Árabes e Judeus: o Encontro Histórico". ${ }^{331}$

Shin Shamlom tratou da poesia hebraica em entrevista à Comentário quando esteve no Rio de Janeiro. Além de comentar, a revista publicava amostras dessa literatura hebraica, como é o caso do conto de Yehuda Yaari, "O Julgamento de Salomão"; as poesias traduzidas por Samuel Scolnicov de Y.

\footnotetext{
${ }^{327}$ Ver artigo de Jehezkel Kaufman (1962) em Tabela de autores internacionais (ver referência).

${ }^{328}$ Ver dele "O Problema Curdo no Iraque", In: Comentário, 1964, N. 2, ANO V, 1964, pp. 107114.

${ }^{329}$ As referências biográficas e de artigos publicados na revista estão nas tabelas em "Anexos".

${ }^{330}$ Fritz Pinkuss, "Dois milênios de migração judaica", In: Comentário, 1960, n. 1, Ano I, pp. 5662.

${ }^{331}$ Henry Siegman. "Árabes e Judeus: O Encontro Histórico", In: Comentário, Ano VII, n. 2, 1966, pp. 150-159.
} 
Amichai, T. Carni, Hayim Guri e Léa Goldberg ${ }^{332}$. Ainda, as traduções feitas por Jacó Guinsburg das poesias de Haim Bialik e de outras obras da literatura hebraica moderna como o conto de Devorá Baron, "No Coração da Cidade", publicado em $1966^{333}$. Guinsburg contribuiu também com uma análise da obra de I.L.Peretz ${ }^{334}$.

A obra e história do teatrólogo brasileiro Antônio José da Silva, vítima da Inquisição portuguesa, recebeu análises na revista, por exemplo, de Bruno Basseches, entre outras. Câmara Cascudo publicou na revista um artigo em que identificou os motivos israelitas na tradição brasileira desde o século XVI: "quando o Brasil nascia". Como parte da história, merece ser registrado o artigo de genealogia tal qual o de Edouard Roditi: "Uma Família Sefaradita". O teatro israelense foi retratado na revista por estudiosos como o brasileiro Arieh Chen $^{335}$.

A música enquanto expressão cultural também não foi negligenciada pela revista. Assim, musicólogos como o israelense Peter Gradenwitz publicaram enriquecendo o conjunto de registros a respeito da cultura judaica representado pela publicação. Ao mesmo tempo publicou-se sobre a "Música Popular Brasileira", nome do artigo de Claribalte Passos sobre o samba desde sua origem ${ }^{336}$.

A Educação no Brasil e os inquéritos propostos pela revista

A educação como tema constante em Comentário refletia uma preocupação constante da intelectualidade brasileira. Aparece pela primeira vez já no primeiro número com artigo do internacionalmente prestigiado e influente educador baiano Anísio Teixeira. Tratava a respeito do Substitutivo da Lei de Diretrizes e Bases, criticando-o enquanto uma forma de "conceder

\footnotetext{
${ }^{332}$ Shin Shalom, "Fé em nossa poesia", In: Comentário, 1960, n. 4, ano I, pp. 57-59.

333 J. Guinsburg, "Poesias de Haim N. Bialick", In: Comentário, 1961, n. 2, ano II, pp. 163-165 e "No Coração da Cidade", In: Comentário, Ano VII, n. 1, 1966, pp. 78-79.

${ }^{334}$ J. Guinsburg, "I. L. Peretz", In: Comentário, Ano VII, n. 2, 1966, pp. 160-172.

${ }^{335}$ As referências biográficas e de artigos publicados na revista estão nas tabelas em "Anexos".

${ }^{336}$ Claribalte Passos, "Música Popular Brasileira, In: Comentário, Ano VIII, n. 1, 1967, pp. 35-
} 40. 
categoria pública ao ensino privado". A avaliação de Teixeira era a de que o estado vinha com essa lei, e seguindo uma tendência, deixar para os particulares o encargo da educação. Defensor que era da Escola Nova que pregava a educação pública gratuita, laica e obrigatória, Teixeira estabeleceu uma dura crítica ao governo ${ }^{337}$ e foi defendido por Adolfo Casais Monteiro em sua empreitada no segundo número da revista do ano de 1961 com "Pensamento e Ação de Anísio Teixeira"338.

Florestan Fernandes também contribuiu a esse respeito com 0 artigo sobre a educação que, segundo ele, deveria ser vista como um problema social para ser transformada em um objeto de luta social dos homens ${ }^{339}$. Esses artigos faziam parte da Campanha em Defesa da Escola Pública, organizada para promover o projeto de lei original de diretrizes e bases da educação nacional e combater o substitutivo encaminhado pelo deputado carioca Carlos Lacerda. A análise sociológica a respeito da situação educacional do país foi desenvolvida por Florestan que entrou na Campanha em 1959 e proferiu diversas conferências a respeito dos perigos do substitutivo, que beneficiariam a escola privada em detrimento da pública ${ }^{340}$.

Outros escreveram sobre o assunto, entre os quais citamos J. Roberto Moreira e os participantes de um Inquérito sobre temas nacionais feitos por Comentário: novamente o educador Anísio Teixeira; Clóvis Salgado, exgovernado de Minas Gerais e ex-ministro da Educação e Cultura; Deolindo Couto, vice-reitor da Universidade do Brasil e vice presidente do Centro Cultural Brasil Israel; José Barreto Filho, professor de psicologia da PUC e membro do antigo conselho Nacional de Educação; Josué Montelllo, então Diretor do Museu Histórico Nacional e membro da ABL, além e nova contribuição de Florestan Fernandes ${ }^{341}$.

O formato "Inquérito" tinha por objeto temas de atualidade nacional, tendo sido bastante utilizado na revista como uma forma "indireta" de debater.

\footnotetext{
337 "A Nova Lei de Diretrizes e Bases: Um Anacronismo Educacional", In: Comentário, 1960, n. 1, ano I, pp. 16-20.

${ }^{338}$ As referências biográficas e de artigos publicados na revista estão nas tabelas em "Anexos".

${ }^{339}$ Ver Florestan Fernandes, "A Educação como problema social", In: Comentário, revista trimestral, Ano I, no. 4, out-nov-dez, 1960, pp. 7-13.

${ }^{340}$ Dados biográficos de Florestan Fernandes no DHBB disponível em http://www.fgv.br/ acesso em 02/03/2011

${ }^{341}$ Cf. "A LEI de Diretrizes e Bases da Educação Nacional - Um Inquérito", In: Comentário, Ano III, ns. 2 e 3, pp 125-130 e 213-220, respectivamente.
} 
Assim, outros temas da época foram alvo de análises. Dentre esses inquéritos citamos: "De que maneira deve o sindicato situar-se na política brasileira"342, "Como vê a Aliança para o Progresso face à realidade brasileira?" ${ }^{343}$. Assim, no seu conjunto, podemos considerar que o corpo editorial da revista Comentário estava atento aos problemas do seu tempo foi marcado pela Diradura Militar, que impunha sua versão aos fatos e clava a produção cultural, assim como seus produtores. Esse periódico representou uma brecha de luz enquanto durou, não conseguindo sobreviver mais por razões óbvias.

Arte e Literatura: sobre o que se tratava e produções inéditas na revista

Comentário publicou críticas, textos literários e resenhas dedicadas aos temas da arte e da literatura. Entre as críticas destacamos as do ensaísta e tradutor judeu húngaro Paulo Ronái (secretário de redação da revista e refugiado no Brasil) e as de Leo Gilson Ribeiro ${ }^{344}$, especializado em Literatura Comparada, que escrevia artigos e resenhas para a revista. Citamos o ensaio documentado "A Literatura de Protesto Americana e As suas Raízes Românticas", que identifica naquela literatura uma ira jovem, característica da revolta romântica perante a realidade, "A Busca do Absoluto Perdido Considerações sobre a obra de Kafka" e "Ionesco, O Cronista do Absurdo e o Teatro de Vanguarda Francês"345. O ensaísta e crítico literário Leo Gilson Ribeiro também escrevia resenhas na seção "Bibliografia", entre as quais

\footnotetext{
342 "De que maneira deve o sindicato situar-se na política brasileira", In: Comentário, Ano III, n. 4, 1962, pp. 309-316. Esse inquérito foi respondido por Dante Pellacani, Diretor Geral do Departamento Nacional de Previdência Social; José Alceu Câmara Portocarreiro, 1ํ. Secretário do Sindicato dos Trabalhadores em Empresas Telefônicas dos Estados da Guanabara, Espírito Santo e Rio de Janeiro; Ary Campista, Presidente da Federação Interestadual dos Trabalhadores nas Indústrias Químicas e Farmacêutica

343 "Como vê a Aliança para o Progresso face à realidade brasileira", In: Comentário, Ano VI, n. 1, 1963, pp. 67-70. Esse inquérito foi respondido por Theóphilo de Andrade, jornalista e diretor de O Jornal e Newton Carlos, responsável pelos assuntos de política internacional do Jornal do Brasil

${ }^{344}$ Ver mais a respeito de Paulo Ronái e Leo Gilson Ribeiro em "TABELAS DE AUTORES", Tabela 2, "In: Comentário: Quadro da Diretoria, Conselho Editorial, Secretaria de Redação e IBJCD.

${ }^{345}$ Leo Gilson Ribeiro, "Literatura de Protesto Americana e as suas Raízes Românticas", In: Comentário, Ano I, №. 1, 1960, pp. 36-41; "A Busca do Absoluto Perdido", In: Comentário, Ano I, no. 4, 1960, pp. 48-55.
} 
destacamos a de Visão do Paraíso de Sérgio Buarque de Holanda, publicada em 1959, pela Livraria José Olympio Editôra ${ }^{346}$.

Publicaram-se textos literários (muitos inéditos) de prestigiados autores nacionais como Lygia Fagundes Telles, Erico Verissimo ${ }^{347}$, Manuel Bandeira ${ }^{348}$, Henriqueta Lisboa, Clarice Lispector, Orígenes Lessa, João Guimarães Rosa e Carlos Drummond de Andrade. Além de análises de aspectos das obras de autores como Machado de Assis, descrito como um geógrafo-historiador por Waldir Ribeiro do $\mathrm{Val}^{349}$. Novos autores também mereceram espaço como foi o caso de Fernando Moreira e o seu conto "Visita Nortuna" publicado no terceiro número do ano de $1961^{350}$ e Osman Lins com o trecho "Um parisiense extranumeral" do livro Marinheiro de Primeira Viagem, em preparação no momento da publicação. Os autores regionalistas - como Guido Wilmar Sassi também escreveram para a revista ${ }^{351}$.

Comentário registrou produções inéditas de importantes nomes da cultura brasileira. Vários deles com reconhecido histórico de posicionamento político de esquerda. Entre eles destacamos o pintor Cândido Portinari, que além de pintor internacionalmente consagrado, havia se revelado poeta no Catálogo da Bienal de 1959. Portinari, em movimento de luta contra o fascismo, teve seu nome incluído na chapa de candidatos do PCB em 1945 ao lado de Jorge Amado e Caio Prado Jr. Em 1956 entregou ao governo brasileiro os encomendados painéis "Guerra e Paz" a serem doados à ONU para ficar em sua nova sede em Nova lorque, o que se deu em seis de setembro de 1957 em cerimônia oficial não divulgada pela imprensa americana, sem a participação das autoridades americanas e sem que Portinari sequer fosse convidado, tudo em virtude de seu envolvimento com o PCB. Em junho de 1956 a convite do governo Israelense, Portinari viajou a Israel com 200 trabalhos a serem

\footnotetext{
${ }^{346}$ Ver em In: Comentário, Ano I, no. 4, 1960, pp. 80-81.

${ }^{347}$ Erico Verissimo, "Estampas da Holanda", In: Comentário, 1960, n. 4, ano I, pp. 30-39.

Tratava-se de um trecho então inédito de um livro de viagem em que o autor comentou, entre outras impressões, a respeito de Anne Frank e opinou a favor da publicação de livros, peça, teatro e filmes sobre o nazismo como uma forma de impedir que o mundo esquecesse para que atrocidades semelhantes não se repetissem.

${ }^{448}$ O poeta traduziu uma poesia de André Gill publicada pela primeira vez por Comentário, intitulada "Horóscopo", In: Comentário, 1960, n. 4, ano I, p. 56. Ver mais na Tabela de Autores Nacionais.

${ }^{349}$ Waldir Ribeiro do Val, "O Rio de Janeiro de Machado de Assis", In: Comentário, Ano II, no. 1, 1961, pp.29-36.

350 "Visita Noturna”, conto, In: Comentário, Ano II, no. 3, 1961, pp. 254-257.

${ }^{351}$ As referências biográficas e de artigos publicados na revista estão nas tabelas em "Anexos".
} 
expostos. Em 1959 publicou na Itália o livro Israel da Série Israe/ desenvolvida a partir dos esboços, estudos e croquis que fez durante a sua estadia naquele país em 1956 e 1957. Os camponeses que sempre marcaram o trabalho de Portinari são retratados por ele em Israel, cuja nova realidade o inspirou ${ }^{352}$.

A revista publicou na parte destinada à ficção, duas poesias inéditas de Cândido Portinari: "A Beduína", escrita em Jerusalém, em junho de 1956 e "Os Retirantes", escrita em Paris, em outubro de 1958. Além de uma ilustração "especial para Comentário":

${ }^{352}$ Cronobiografia de Portinari em site do Projeto Portinari, pp. 35-40, em www.portinari.org.br, acesso em 15/02/2011 e Maria Luiza Tucci Carneiro, 'Imagens de Israel por Portinari', In: Candido Portinari. Portinari em Israel. São Paulo, Centro de Cultura Judaica, 2010. Catálogo bilíngüe. 


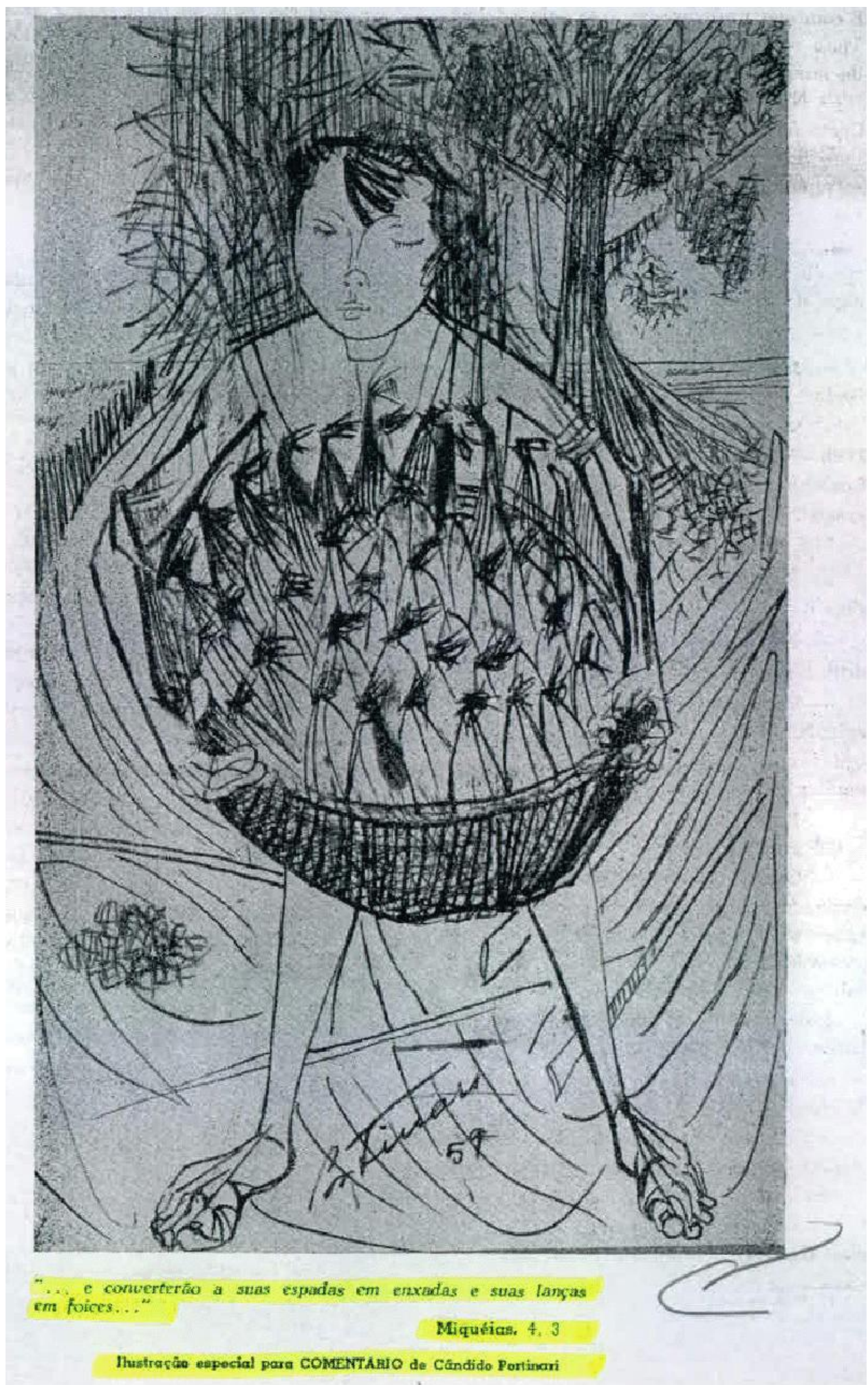

2 - "Ilustração especial para Comentário, de Cândido Portinari", In: Comentário, Ano I, n. 1, 1960, p. 69. 
Em 1962 Cecília Meireles traduziu poemas para o livro "Poesia de Israel" com desenhos de Cândido Portinari pela Editora Civilização Brasileira ${ }^{353}$.

Ainda no campo da expressão artística mereceu destaque vida e obra do artista lituano naturalizado brasileiro em 1923 e sua arte retratados pela revista em 1962 através da "Homenagem a Lasar Segal”, falecido em 2 de agosto de 1957, onde foi publicada uma fotografia do pintor judeu e reproduzidas algumas de suas obras. Foi Geraldo Ferraz, romancista e crítico de Arte d'O Estado de S. Paulo e da Tribuna de Santos quem escreveu "Meditação sobre Lasar Segall”.

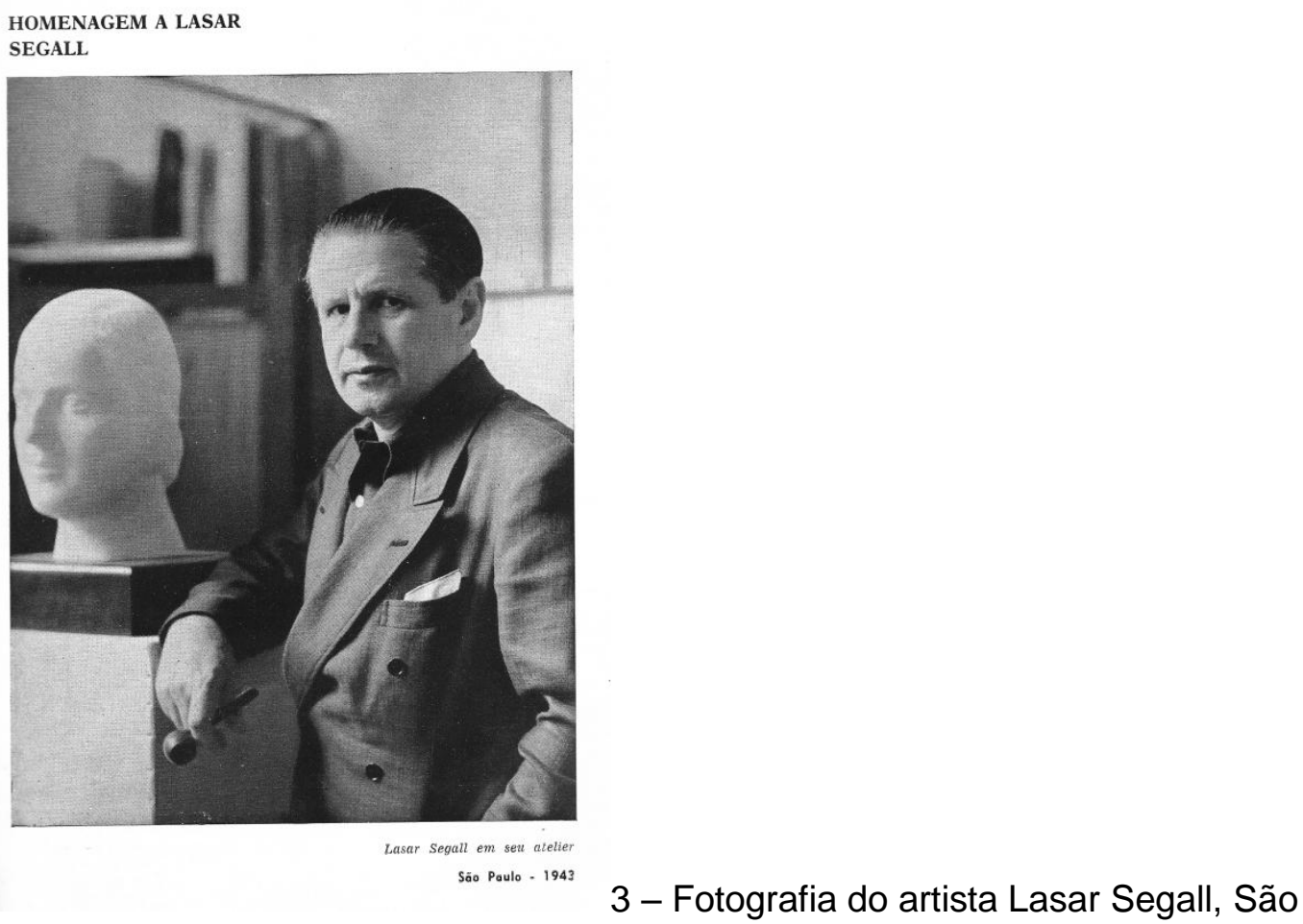

Paulo, 1943, In: Comentário, Ano III, n. 3, 1962, entre as páginas 224-225.

${ }^{353}$ Cf. “Registro Literário”, seção Bibliografia, In: Comentário, ANO III, n. 3, 1962, p. 283. 


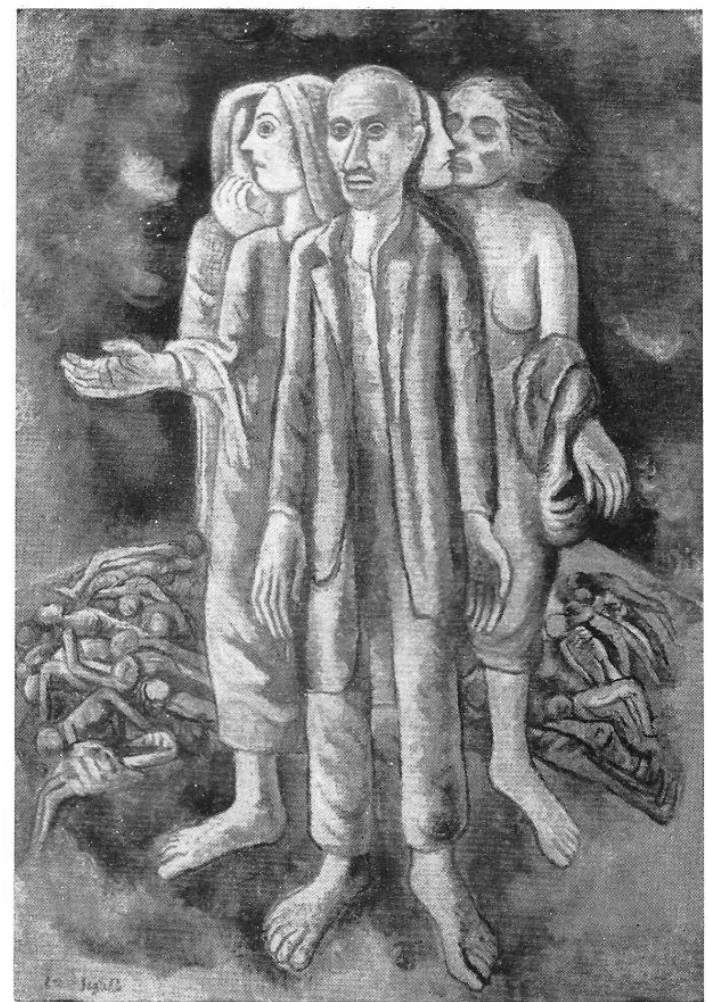

"Sobreviventes", 1941

oleo 4 - "Sobreviventes", 1941, óleo, Lasar Segall, In: Comentário, Ano III, n. 3, 1962, entre as páginas 224-225.

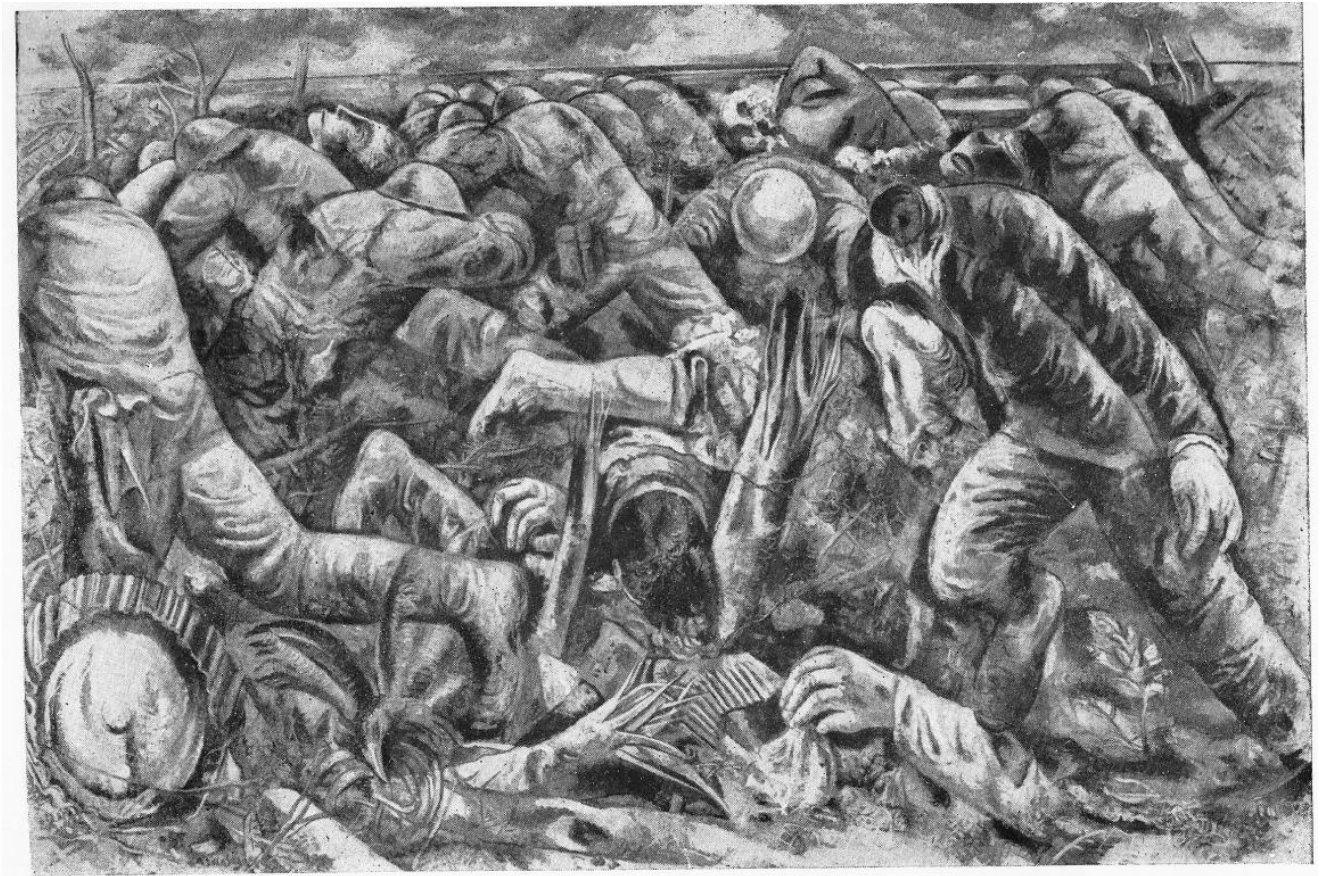

"Guerra", 1942

óleo

5 - "Guerra", 1942, óleo, Lasar Segall, In: Comentário, Ano III, n. 3, 1962, entre as páginas 224-225. 


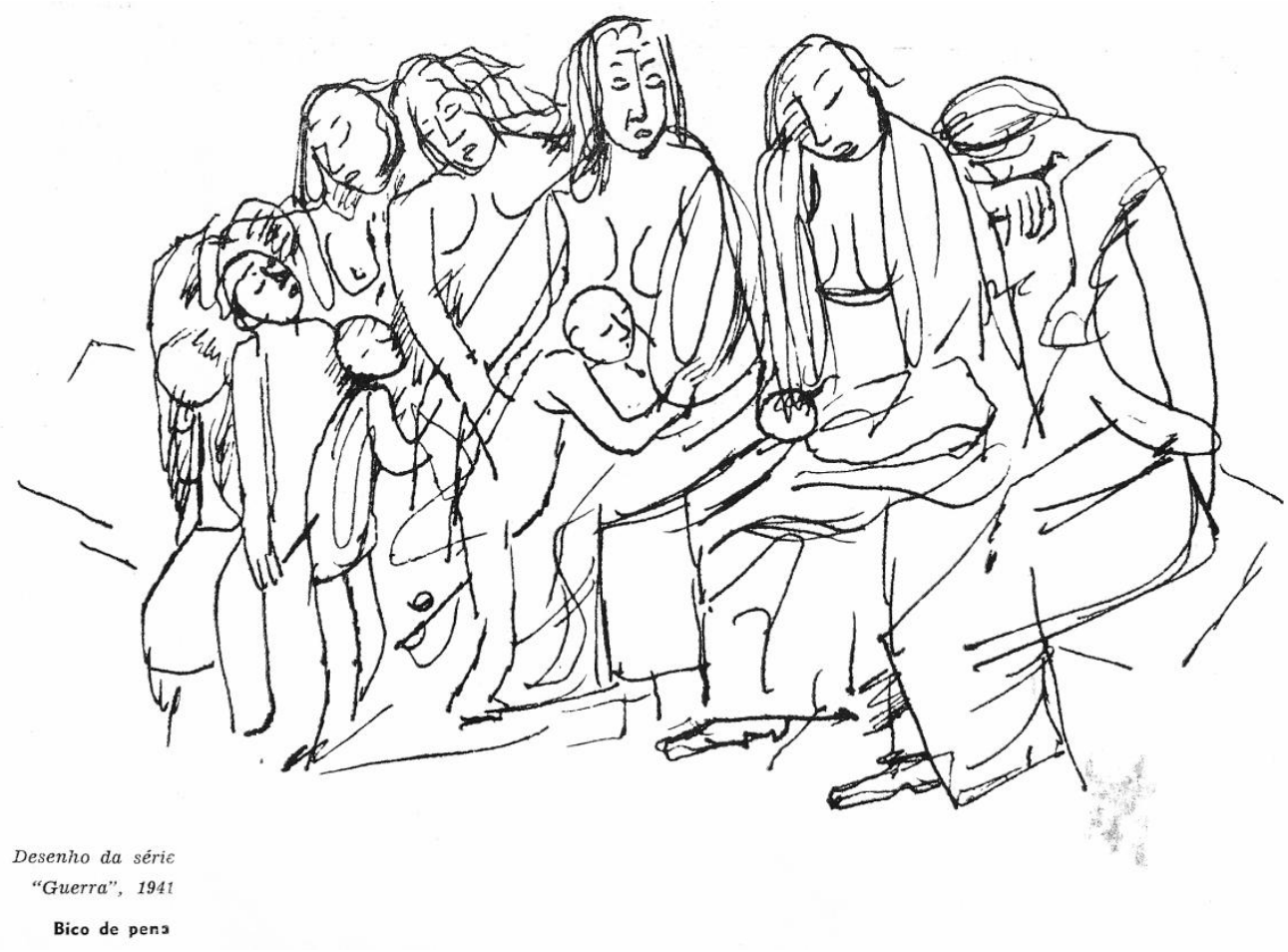

6 - Desenho da série "Guerra", 1941, bico de pena, Lasar Segall, In: Comentário, Ano III, n. 3, 1962, entre as páginas 224-225. 


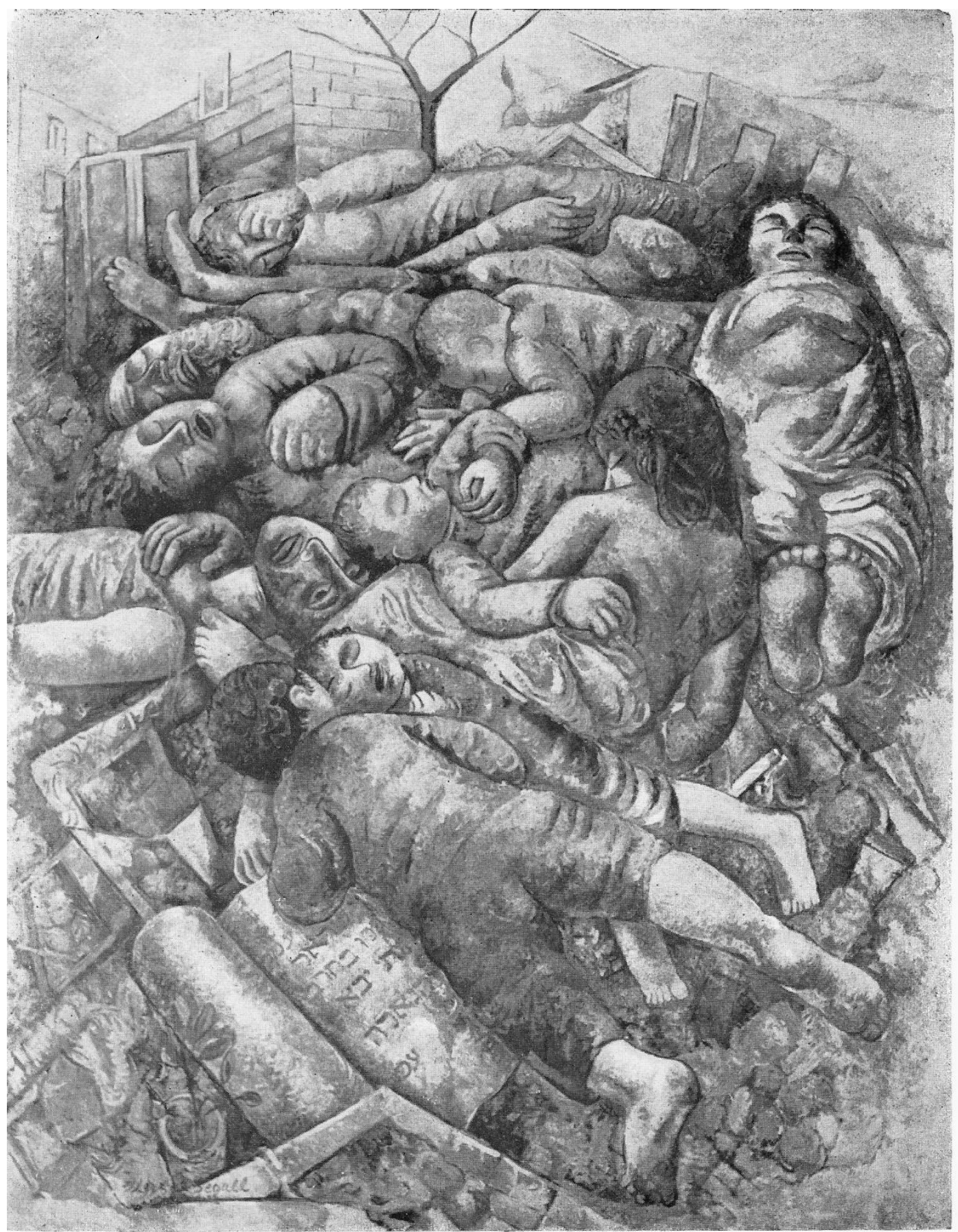

"Pogrom", 1936-37

7 - "Pogrom", 1936-37, Lasar Segall, In: Comentário, Ano III, n. 3, 1962, entre as páginas 224-225. 

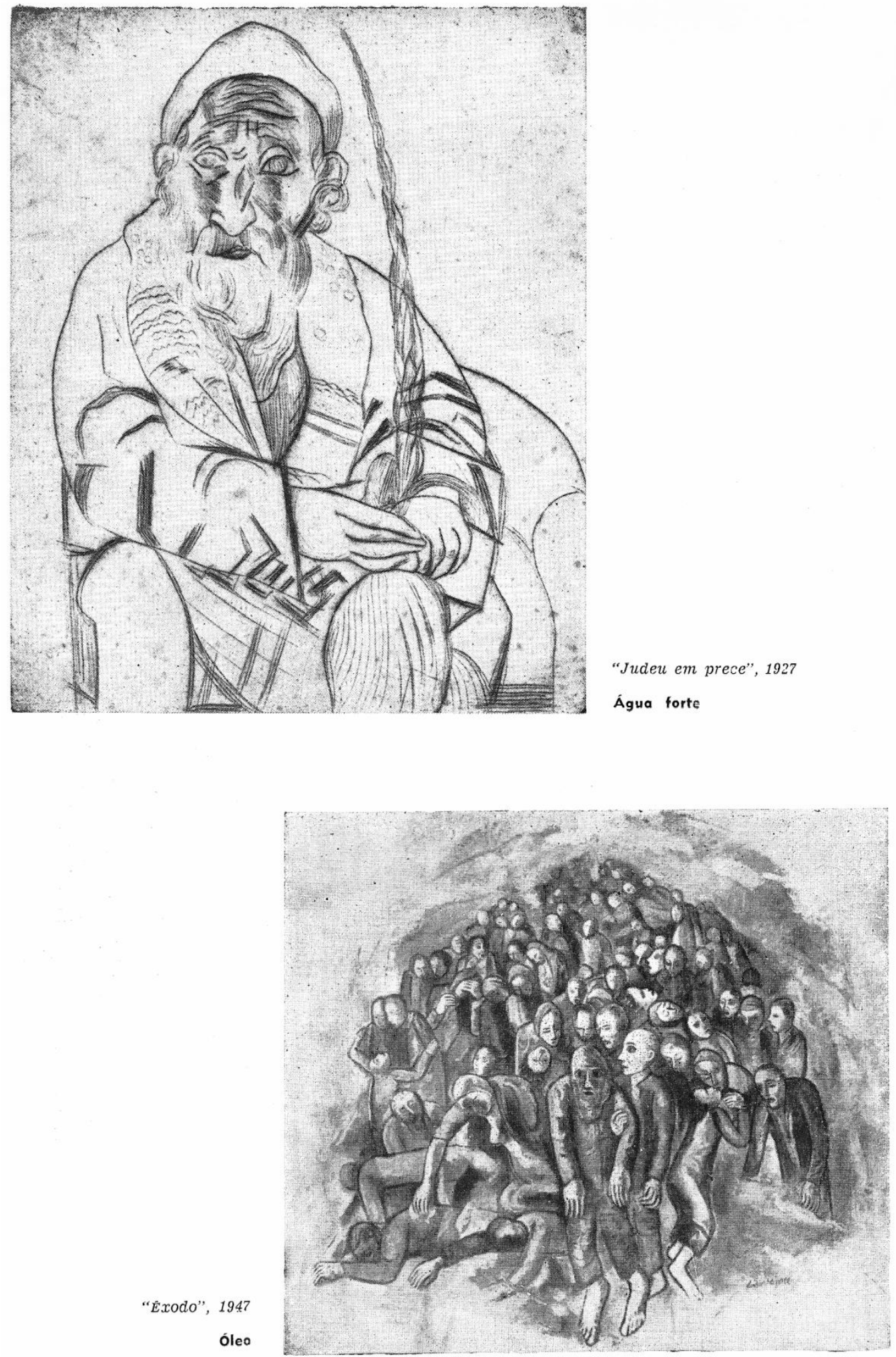

8 e 9 - "Judeu em prece", 1927, água forte e "Êxodo", 1947, óleo, Lasar Segall, In: Comentário, Ano III, n. 3, 1962, entre as páginas 224-225. 


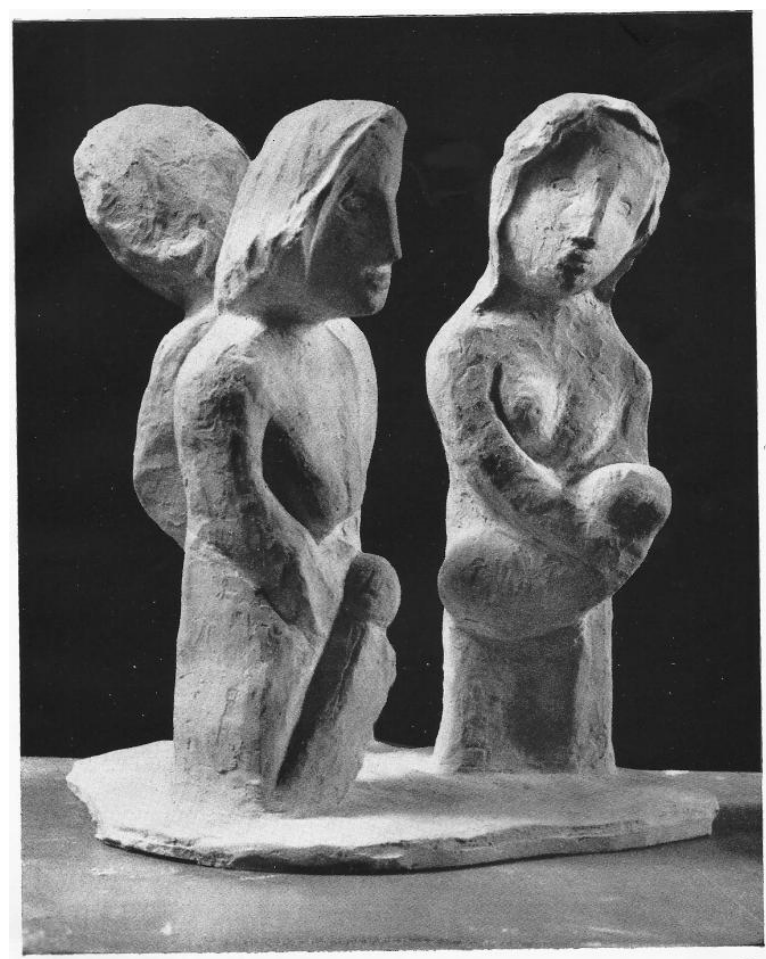

"Maes errantes", 1951 - "Mães Errantes", 1941, bronze, Lasar Segall, In: Comentário, Ano III, n. 3, 1962, entre as páginas 224-225.

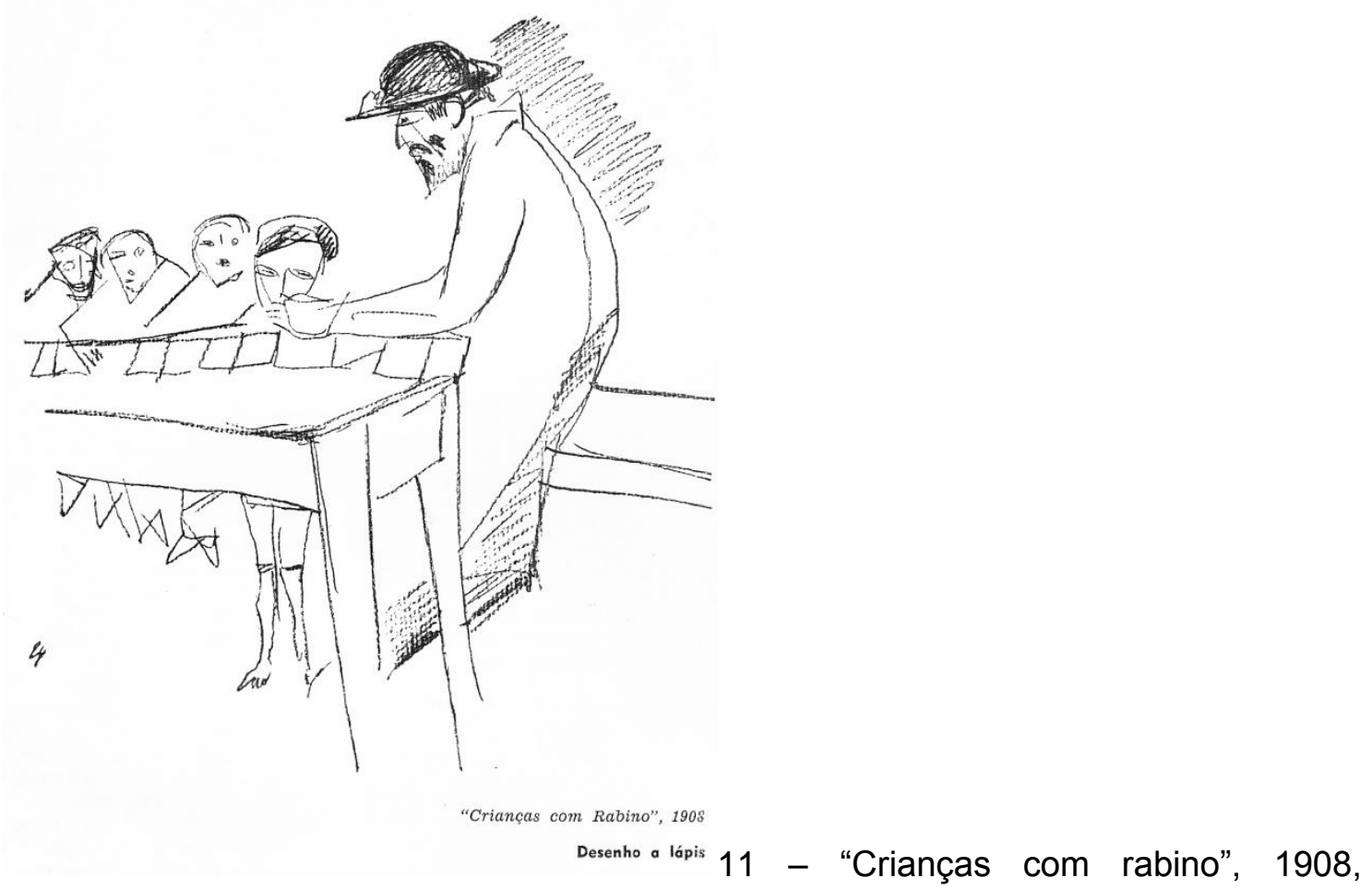

desenho à lápis, Lasar Segall, In: Comentário, Ano III, n. 3, 1962, entre as páginas 224-225. 
Estilos da Arte contemporânea mereceram análises de especialistas como José Roberto Teixeira Leite em "Reflexões sôbre a pop art" ${ }^{\text {"354, por }}$ ocasião da primeira exposição de pop art no início de 1965 no Museu de Arte Moderna de Nova lorque.

Olhares sobre o Brasil

Os estudos culturais e regionais do Brasil desenvolvidos por antropólogos e sociólogos mereceram destaque na revista Comentário que, em diferentes momentos, preocupou-se em analisar a imigração e outras tantas "questões" político-sociais como, por exemplo, a questão indígena, o direito dos naturalizados, os crimes contra a humanidade, apenas para citar alguns. Temas tabus que, certamente, melindravam as versões sustentadas pela História Oficia ${ }^{355}$. Cumpre citar o artigo de autoria de Manuel Diégues Júnior publicado em 1960, originalmente apresentado no Seminário sobre Resistência à Mudança, organizado pelo Centro Latino-Americano de Pesquisas Sociais em outubro de 1959. Neste artigo o autor aborda a imigração como uma forma de contribuição ao processo de desenvolvimento econômico e social ${ }^{356}$, citando como um trabalho de referência Race and Nationality in American Life (1957) de Oscar Handlin. Filho de imigrantes judeus russos, Handlin nasceu em Nova lorque e se tornou o historiador oficial do $A J C^{357}$, professor de Harvard, prêmio Pulitzer (por Uprooted, em 1951) e um influente pesquisador no final da década de 1950 com trabalhos nos campos dos direitos civis, liberdade, etnicidade, história urbana, história da educação, relações exteriores, migração, biografia, adolescência e até poesia ${ }^{358}$.

\footnotetext{
354 José Roberto Teixeira Leite, "Reflexões Sôbre a Pop Art", In: Comentário, Ano VII, n. 3, 1966, pp. 253-259. O autor havia sido Diretor do Museu Nacional de Belas-Artes.

${ }^{355}$ Marc Ferro. Os Tabus da História, Rio de Janeiro, Ediouro, 2003.

${ }^{356}$ Manuel Diégues Júnior, "A Imigração e o Desenvolvimento", In: Comentário, revista trimestral, Ano I, no. 2, abr-mai-jun de 1960, pp. 16-22.

${ }^{357}$ Nathan Abrams, "'America is Home' Commentary Magazine and the Refocusing of the Community of Memory, 1945-1960", In: Murray Friedman (editor), Op. Cit., 2005, p. 11.

${ }^{358}$ Sobre Oscar Handlin ver http://www.harvardsquarelibrary.org/cfs/oscar handlin.php, acesso em 22/02/2011.
} 
Entre os artigos que abordaram a questão da etnicidade está "O índio na consciência nacional", do antropólogo Roberto Cardoso de Oliveira, Diretor da Divisão de Antropologia do Museu Nacional e Secretário da Associação Brasileira de Antropologia. Valendo-se de uma abordagem científica avaliou a situação dos índios no Brasil, descortinando uma série de preconceitos que envolviam este grupo, ainda hoje uma "questão"359.

Reconhecidos intelectuais da área de direito comentaram a respeito dos direitos dos naturalizados como Arnold Wald, Procurador do Estado da Guanabara, que destacava a importância da integração no novo país daqueles que, na condição de imigrantes, haviam escolhido o Brasil como país de acolhimento. Interessante notar a persistência de uma mentalidade jurídica herdada da década de 1940, das práticas de intervenção nacionalistas e xenófobas do Estado Novo brasileiro que "via" nos chamados "Súditos do Eixo" redes de espionagem, sociedades conspirativas e inimigos para todos os lados $^{360}$. Tratando como oportuna a criação da Liga de Brasileiros Naturalizados, que em fins de novembro de 1959 pleiteara a reforma constitucional a fim de assegurar a ampliação dos direitos dos naturalizados e a sua equiparação aos brasileiros natos, Wald ressaltava a necessidade de algumas medidas de proteção, a fim de se evitar a formação de "núcleos de súditos de países estrangeiros não assimilados à vida nacional, que podem pôr em perigo a própria segurança do país, como aconteceu a certos grupos de japoneses e alemães durante a última guerra mundial”361.

Além de Arnold Wald, escreveram sobre questões jurídicas os advogados Elias Lipiner ${ }^{362}$ e Isaac Schifnagel. Este último analisou, em 1965, o

\footnotetext{
${ }^{359}$ Roberto Cardoso de Oliveira, "O Índio na Consciência Nacional", In: Comentário, Ano VI, n. 2, pp. 126-131.

${ }_{360}$ Ver a esse respeito os trabalhos de Marcia Yumi Takeuchi : O perigo amarelo em tempos de guerra, 1939-1945, São Paulo, Arquivo do Estados, Imprensa Oficial do Estado, 2002 e $O$ Perigo Amarelo: imagens do mito, realidade do preconceito, São Paulo, Humanitas, 2008. Ver ainda os trabalhos de Priscila Ferreira Perazzo: Os Súditos do Eixo" nos campos de concentração brasileiros (1942-1945), São Paulo, Humanitas/ Imprensa Oficial do Estado/ Fapesp, 2009 e O Perigo Alemão e a Repressão Policial no Estado Novo, São Paulo, Arquivo do Estado/Imprensa Oficial, 1999.

${ }^{361}$ Arnold Wald, "Os Direitos dos Naturalizados no Brasil", In: Comentário, 1960, n. 2, ano I, p. 41.

${ }^{362}$ Elias Lipiner, "Pena de Morte na Antiga Legislação Hebréia", In: Comentário, Ano II, no . 4, 1961, pp. 302-307. Lipiner também escreveu: "O Anagrama na solução de alguns problemas quinhentistas", In: Comentário, Ano V, no. 2, 1964, pp. 149-153; "Reabilitação de Sylvio Romero", In: Comentário, Ano V, no. 4, 1964, pp. 332-340; "Tendências de Arrependimento manifestadas pelos portugueses após a expulsão dos judeus", In: Comentário, Ano VII, n. 1,
} 
conceito de prescrição à luz do Direito Internacional tomando como referência o caso específico dos crimes nazista. Tema oportuno e ainda "indigesto" pois a Alemanha Ocidental acabara de prorrogar o prazo de prescrição daqueles crimes até 1 de janeiro de $1970^{363}$.

Questõs urbanísticas e econômicas também foram alvo de atenção por parte dos autores da Comentário que, sob diferentes olhares, avaliaram as carências da sociedade brasileira. Brasília, recém-inaugurada em abril de 1960, foi abordada pelo geógrafo Moisés Gikovate a partir da geopolítica. Para o autor havia a necessidade urgente de se ocupar e desenvolver o interior, respondendo às exigências demográficas e econômicas da região ${ }^{364}$.

As favelas cariocas, por sua vez, foram alvo de análise de José Arthur Rios que as interpretava como "um fenômeno de proletarização que começa no campo e chega à sua conclusão lógica nas cidades". Ele sugeriu um conjunto de reformas de estrutura para a supressão desse proletariado rural e urbano e o aumento do poder aquisitivo dessas populações ${ }^{365}$.

Os problemas econômicos também receberam espaço na revista com artigos assinados pelo economista W. A. Lewis. Os problemas decorrentes da inflação foram analisados pelo jurista e economista, então deputado Aliomar Baleeiro e o parque Industrial brasileiro foi analisado dentro da nova fase econômica do país por Eliezer Burlá, professor de Comunicação da PUC. Contribuiu também Mário Henrique Simonsen, em 1966 um economista da nova geração.

Outro assunto de grande repercussão na imprensa que se tornou alvo de debate junto a Comentário foi o projeto sobre a Reforma Agrária discutido na Câmara dos Deputados em 1962 e que mereceu um inquérito respondido por D. Eugênio Sales, Arcebispo-Auxiliar de Natal, o deputado José Joffily e o engenheiro agrônomo Wanderbilt de Barros ${ }^{366}$. Em contrapartida à

1966, pp. 39-46, "A Pena de Morte na História do Direito Nacional", In: Comentário, ano XI, n. 2, 1970, entre outros.

${ }^{363}$ Isaac Schifnagel, “Prescreverão os Crimes Nazistas?", In: Comentário, Ano VI, n. 3, 1965, pp. 207-215.

364 "Brasília - Ideologia e Revolução - o Ciclo da Civilização do Interior", In: Comentário, Ano I, o.. 3, 1960, pp. 9-15.

365 José Arthur Rios, "As Favelas na Paisagem da Guanabara", In: Comentário, Ano V, № 1, 1963, pp. 24-28.

${ }^{366}$ Ver "Reforma Agrária: Um Inquérito", In: Comentário, jan-fev-mar, ano III, n.. 1, 1962, pp. 23 27. 
necessidade de se fazer a reforma agrária no Brasil, Comentário publicou em seguida ao "Inquérito" um artigo de Abraham Granot, diretor do Keren Kayemet Leisrael (Fundo Agrário de Israel) sobre a bem sucedida política agrária de Israel.

Artigos sobre o desenvolvimento científico no Brasil reforçavam a já citada característica da revista de penetração cultural voltada para um público universitário, acadêmico. O artigo "Os Problemas do Desenvolvimento Científico no Brasil", de Octacilio Cunha, Vice-Almirante e então Presidente do Conselho Nacional de Pesquisas, apontava para a necessidade emergencial de uma política de desenvolvimento científico para se desenvolver o país.

\section{O Caso Eichmann}

Nazismo, nazistas e antissemitismo eram temas fundamentais para a revista Comentário cujos autores eram, na sua maioria, judeus que haviam vivenciado as crueldades do Holocausto, enquanto crime contra a Humanidade. Neste contexto de críticas por parte de alguém que viveu o nazismo na própria carne é que devemos entender a impressão de Varsóvia registrada pelo escritor e educador judeu Chaim A. Kaplan. Refletindo a respeito da crueldade nazista, interpretada como uma "doença", o autor valeuse de um conjunto de metáforas para analisar a questão do sadismo e da insanidade sem limites:

A crueldade é uma doença. (...) O sádico também é um infeliz, mas não merece piedade. Dêsse ponto de vista, o nazista é um ser doente e infeliz. Já tínhamos visto antes indivíduos cruéis, mas desde que o nazismo apareceu, a crueldade tornou-se a doença de todo um partido, e talvez de toda uma nação. Mesmo os sádicos costumavam sentir vergonha; sua crueldade era perpretada em lugares secretos, não em público. Mas desde o advento do nazismo, a vergonha pública despareceu e quanto mais se pratica a crueldade em público melhor. (...) O único consôlo é que nazismo é insanidade - mas isso não é conforto para o judeu espancado e sangrando... ${ }^{367}$

${ }^{367}$ Chaim A. Kaplan, “Um Diário do Gueto de Varsóvia”, In: Comentário, Ano VII, n. 2, p. 128. 
O caso Eichmann aparece a partir do terceiro trimestre de 1960 na revista Comentário em artigos como o do historiador León Poliakov intitulado "Indústria da Morte", trecho extraído de sua obra Breviário do Ódio (Os Judeus e o Terceiro Reich), selecionado pelos editores de Commentary com objetivo de contrapor as noções de jurisprudência relacionadas à soberania e ao direito internacional, assunto que vinha alcançando grande repercussão na imprensa. No artigo, Poliakov descreveu o genocídio judeu e as atividades de seus protagonistas citando "o caso Eichmann".

Os segundo, terceiro e quarto número da revista de 1961 contêm um mesmo anúncio do livro de Comer Clarke intitulado "O Retrato de um Monstro: Eichmann, Assassino de Milhões, com capa de Lazar Segall, em composição de Carybé traduzido por Tati Morais e Fernando Sabino" (que o comenta na seção "Bibliografia", p. 183 do segundo número) e apresentando visão que Hannah Arendt irá questionar em Eichmann em Jerusalém - um relato sobre a banalidade do mal (1963), que por seu título reflete o conteúdo segundo o qual - depois de assistir ao julgamento do nazista, enviada como jornalista pela revista New Yorker:

"O problema com Eichmann era exatamente que muitos eram como ele, e muitos não eram nem pervertidos, nem

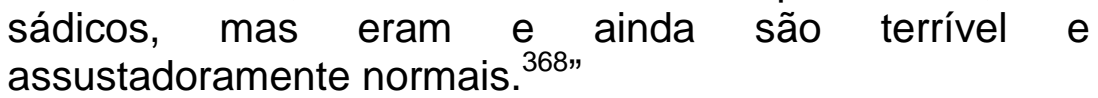

Arendt desenvolveu uma teoria onde defendia que o totalitarismo transformava os homens em engrenagens automatizando-os, desumanizandoos. Porém, Hannah Arendt não o eximiu de sua culpa diante da lei (de natureza objetiva) que o condenava, embora não encontrasse justificativa de criminalizálo por nenhuma contravenção dentro do sistema legal alemão em que ele esteve inserido enquanto responsável por diversas atividades associadas à chamada "solução final" ou extermínio dos judeus. A análise desapaixonada a respeito de se a corte de Jerusalém esteve à altura das exigências da justiça fez com que Arendt, de origem judia, sofresse reveses por parte de

${ }^{368}$ Hannah Arendt, Eichmann em Jerusalém, São Paulo, Cia das Letras, 1999, p. 299. 
organizações judaicas e acabasse por estremecer suas relações de amizade com muitos intelectuais judeus.

Norman Podhoretz escreveu em Commentary, "Hannah Arendt on Eichmann: a Study in the Perversity of Brilliance", texto onde criticou o livro gerando um afastamento entre eles, antes amigos. Depois disso, ainda que convidada por Podhoretz, Hannah nunca mais escreveu para Commentary ${ }^{369}$.

No seu segundo número do ano de 1961, Comentário publicou uma nova seção intitulada "Documentos" contendo o "Libelo de Israel contra Eichmann" redigido pelo Procurador Geral Gideon Hausner contendo as quinze acusações $^{370}$. No número seguinte, na "seção bibliografia", publicou a resenha de Mário Teles a respeito do livro do jornalista americano Quentin Reynolds Reynolds-Katz-Aldouby: Ministro da Morte (O Caso Eichmann) ${ }^{371}$ - com base em diversos documentos. Ao comentar a parte do livro que trata dos assuntos diplomáticos e legais referentes ao caso o autor indignou-se terminando com a frase "Aos homens e mulheres de Israel que preferiram não esquecer que a justiça é feita a quem a procura." 372

O debate em torno do caso Eichmann, portanto, gerou uma série de artigos e reflexões em Commentary sendo alguns escolhidos para serem publicados na revista brasileira. Um destes textos, próximo da linha de reflexão de Hannah Arendt, questionava se o episódio nazista representava tão somente a Alemanha, sugerindo que era na verdade emblemático do conjunto da civilização, apontando a guerra fria como "um sintoma ulterior e mais virulento da mesma desordem". Este é o caso, por exemplo, do artigo publicado em Comentário em 1962 do editor nova-iorquino Jason Epstein, que, mais tarde, em abril de 1967 publicará o artigo-denúncia na revista New York Review of Books, "The CIA and the Intellectuals", tratando do anticomunismo americano sendo literalmente financiado pela agência governamental norte-

\footnotetext{
${ }^{369}$ Cf. a versão dos fatos Segundo Podhoretz em Norman Podhoretz, Ex-Friends. Falling out with Allen Guinsberg, Lionel and Diana Trilling, Lillian Hellman, Hanna Arendt, and Norman Mailer, California: Encounter Books, 2000, pp. 152-177.

${ }^{370}$ Gideon Hausner, Procurador Geral, "Libelo de Israel contra Eichman", Tribunal do Distrito de Jerusalém, Jerusalém, 1/02/1961, In: In: Comentário, n. 2, ano II, 1961, pp. 176-182.

${ }^{371}$ Quentin Reynolds Reynolds-Katz-Aldouby: Ministro da Morte (O Caso Eichmann) Tradução de Diana Mello Moreira Lima - Coleção Catavento - Editôra Globo, Pôrto Alegre, 1961.

${ }^{372}$ Cf. Mário Teles, "Eichmann enfrenta a Humanidade", In: Comentário, seção "Bibliografia", n. 3, ano II, 1961, p. 285.
} 
americana envolvendo os antigos intelectuais de esquerda, cientes ou não dessa empreitada. Em "O Julgamento de Nuremberg: Comentários sobre um filme" publicado em 1962, Epstein criticou certos aspectos do filme do diretor Stanley Kramer apontando, no entanto, para a conexão que este faz entre política e morte, desenvolvendo um ensaio autocrítico e da política americana.

Quando o julgamento de Eichmann começou, o Instituto Brasileiro Judaico de Cultura e Divulgação imprimiu uma série de cartilhas e folhetos e emitiu vários comunicados de imprensa. Também patrocinou a publicação de um livro sobre os crimes de Eichmann para distribuição nacional $\left.\right|^{373}$.

Literatura de Testemunho e Culpa Alemã

A literatura de testemunho do universo concentracionário encontrou espaço na revista. Em 1962, o secretário de redação de Comentário, Paulo Rónai, reproduziu um trecho do então recente livro húngaro Subleva-se o Túmulo sob o título de "No Campo de Mulheres de Birkenau" da Sra. Gabriel Vidor (Vidor Gáborné), que narra quinze anos depois as suas terríveis experiências. Rónai justificou a publicação como "oportuna e instrutiva" naquele momento em que se acompanhava o julgamento de Eichmann ${ }^{374}$.

O depoimento do jornalista e tradutor de peças literárias Mário Silva tem valor testemunhal por estar na Alemanha como correspondente de um jornal italiano quando Hitler ascendeu ao poder em 1933. Ele foi expulso do jornal em que trabalhava em função das opiniões que expressava a respeito do nacionalsocialismo ${ }^{375}$. Ainda foram publicados materiais como as cartas trocadas entre duas amigas que também se prestam como documentos de uma época. Halina Szwambaum se correspondeu com Stefânia Lilienthal entre junho de 1941 até junho de 1942 enquanto esteve no gueto de Varsóvia ${ }^{376}$. Ainda a publicação do

\footnotetext{
${ }^{373}$ Cf. Alfred Hirschberg e Abraham Monk, "Brasil", Foreign Coutries: Latin America, American Jewish Year Book (AJYB), Vol. 63, 1962, p. 481. In:

http://www.ajcarchives.org/AJC DATA/Files/1962 16 LatinAmerica.pdf, acesso em 6/04/2011. ${ }^{374}$, Sra. Gabriel Vidor, "No Campo de Mulheres de Birkenau", In: Comentário, n. 1, ano III, 1962, pp. 63-66.

${ }^{375}$ Mário Silva, "Nazismo e Antissemitismo", In: Comentário, Ano I, n. 2, 2o trimestre de 1960, pp. 32-38.

376 "Quatro cartas do Gueto de Varsóvia", In: Comentário, n. 4, Ano III, 1961, pp. 340-347.
} 
conto do escritor Tadeusz Borowski “À Câmara de gás, por aqui”, traz a dimensão do testemunho de quem viveu em campo de concentração na Segunda Guerra ${ }^{377}$.

Em 1966, Comentário publicou fragmentos do diário produzido pelo erudito escritor e educador Chaim. A. Kaplan, morto em Treblinka com sua esposa em 1942 ou 1943. O Diário havia sido descoberto em 1960 pelo Prof. Abraham I. Katsh, da Universidade de New York, durante uma visita ao Instituto Histórico Judaico de Varsóvia. Os excertos publicados cobrem o período que vai de 7 de dezembro de 1939 a 4 de agosto de 1942 e revelam o clima de desespero do que foi a tragédia judaica no gueto de Varsóvia.

A destruição "legal" enegreceu o nosso mundo, mas até isso já se tornou assunto para piadas judaicas. Humor negro. Receio uma psicose do desepêro que permeia nossas vidas. Cessamos de reagir. Mesmo que nos proíbam de respirar, acabaremos aceitando-o. E faremos isso tema de uma nova piada. ${ }^{378}$

Por outro lado se analisou os efeitos de culpa sobre a cultura alemã pósnazismo naquele momento ainda um passado muito próximo. Através da literatura alemã, Theodore Frankel desenvolveu uma análise nesse sentido ${ }^{379}$. As exposições a respeito da cultura judaica patrocinada por cidades alemãs foram retratadas por Herbert Caro - refugiado do nazismo em Porto Alegre e um dos maiores tradutores de língua alemã no Brasil - enquanto o "desejo de cooperar na Reparação Moral”380.

Temos aqui testemunhos e traumas de diferentes naturezas partindo de pessoas que ocuparam diferentes lugares durante o Holocausto. Márcio Seligmann-Silva em seus estudos a respeito da literatura de testemunho sobre a Shoah destacou a marginalidade do tema e sua pouca receptividade no Brasil de um modo geral ${ }^{381}$. Importante notar Comentário enquanto uma publicação que colocava a questão. Daí entendermos a revista enquanto um

\footnotetext{
377 Tadeusz Borowski "'À Câmara de Gás, por aqui”, Comentário, Ano IV, n. 1, 1963, pp. 57-66. ${ }^{378}$ Chaim A. Kaplan, "Um Diário do Gueto de Varsóvia", In: Comentário, Ano VII, n. 2, p. 118. 379 Theodore Frankel, "A Ficção Alemã e a Busca da Purificação", Comentário, 1961, n. 2, Ano II, pp. 139-143.

${ }^{380}$ Herbert Caro, "A "Reparação Moral" em duas Exposições Alemãs", Comentário, Ano III, no․ 1, 1962, pp.52-62.

${ }^{381}$ Márcio Seligmann-Silva, "Literatura da Shoah no Brasil", Arquivo Maaravi, Revista Digital de Estudos Judaicos da UFMG, Vol. 1, n. 1, 2007, p. 1.
} 
espaço importante de divulgação da memória do trauma que é entendida por Selligman enquanto "uma busca de compromisso entre o trabalho de memória individual e outro construído pela sociedade"382.

A guerra do Vietnam e A Guerra dos Seis Dias

O primeiro artigo sobre a Guerra do Vietnam (1965-1975) foi publicado no número 1 do ano de 1965, sendo de autoria de Donald S. Zagoria, então membro do Instituto de Pesquisa de Assuntos Comunistas na Universidade de Columbia. A política de conter o comunismo no Vietnã por parte dos Estados Unidos foi classificada como inepta pelo autor que avaliou as raízes do comunismo na Ásia associando-a ao "comunalismo". As tensões culturais proporcionariam fácil entrada da proposta comunista num sentido de uma igualdade de classes e de uma dignidade e identidade racial e nacional, o que "perfuradoras, tratores, fertilizantes e aviões americanos" seriam incapazes de oferecer. $\mathrm{O}$ autor justificou o afastamento do Ocidente em virtude dos frutos do colonialismo, sobretudo a desintegração social ${ }^{383}$.

O segundo artigo foi publicado no quarto trimestre de 1965 na revista brasileira e redigido pelo jornalista David Halberstam do New York Times, que tratou do conflito entre a imprensa e a missão americana, denunciando a adaptação da notícia em relação à política americana que falhava naquela região. A matéria teria sido publicada com teor bem mais otimista do que de fato estaria acontecendo na região de modo a proteger as ações do geoverno perante a opinião pública ${ }^{384}$.

As inquietações diante da guerra geraram uma mesa-redonda promovida por Commentary cujo texto resultante foi reproduzido em Comentário no último número de 1966. A questão que se colocava era se a

\footnotetext{
382 Márcio Seligmann-Silva, "Narrar o trauma - A questão dos testemunhos de catástrofes históricas", In: Psicologia Clínica, Vol. 20, n. 1, Rio de Janeiro, 2008, p. 2. Ver ainda do autor: "Reflexões sobre a memória, a história e o esquecimento", In: M. Seligmann-Silva (org.) História, Memória, Literatura. O testemunho na era das catástrofes, Campinas: Editora da UNICAMP, 2003, pp. 59-89.

${ }_{383}$ Donald S. Zagoria, “As Tensões na Ásia”, In: Comentário, Ano VI, n. 1, 1965, pp. 5-13.

${ }^{384}$ David Halberstam, "Fazendo a notícia no Vietnam", In: Comentário, Ano VI, n. 4, 1965, pp. 293-300.
} 
finalidade da política norte-americana no extremo Oriente tinha por objetivo deter a expansão chinesa ou a difusão do comunismo, pois que os Estados Unidos supunham estar no Vietnam contendo a China na Ásia, tal como contiveram a União Soviética na Europa em 1947. Dentre os participantes da mesa coordena por Norman Podhoretz estavam Bernard B. Fall, professor de relações internacionais na Universidade de Harward, Richard N. Goodwin, que havia sido acessor especial dos presidentes Kennedy e Johnson, o senador George McGovern e o Professor de História e de Política da Universidade de Brandeis John P. Roche. Hannah Arendt esteve presente e fez perguntas. Em nota a revista a descreveu como autora de Eichmann in Jerusalem, "que provocou várias discussões"385.

Em artigo de 1968, o jornalista francês Richard Marienstras escreveu que os judeus de um modo geral condenaram a política de agressão ao Vietnam dos Estados Unidos. Sobre as conseqüências da Guerra de 1967, aderindo ao manifesto de Sartre e outros intelectuais em apoio a Israel, o autor associou o argumento árabe de que Israel era produto de uma violência injustificável, exercida por motivos capitalistas e comercias a um alinhamento com a política soviética, de modo que o Oriente Médio tornara-se um lugar privilegiado de combate entre as duas grandes potências da época. A relação estabelecida com o Vietnam era a de que a violência poderia cessar se os EUA saíssem da região, crítica arrojada para a época. No entanto em Israel, a paz dependia dos dois lados: os estados árabes e o judeu. Esse momento marcou uma divisão na esquerda, situação registrada pela revista Comentário ${ }^{386}$ que cumpria, também com o seu papel de órgão de crítica e combate à violência movida por questões ideológicas.

\footnotetext{
${ }^{385}$ Cf. "Para deter a China”, mesa-redonda, In: Comentário, Ano VII, n. 4, pp. 309-336.

${ }^{386}$ Richard Marienstras, "Israel não é negociável”, In: Comentário, Ano IX, 1968, pp. 117-123.
} 


\section{CONSIDERAÇÕES FINAIS}

Quais as utopias que movem os homens do século XXI? As mesmas dos séculos XIX, XX e de que tantas notícias nos traz Comentário? Uma delas, com certeza, persistiu ao longo dos séculos: o desafio de (con)viver para se bem viver, investindo no fortalecimento de laços com o outro, relações essas que por natureza são carregadas de tensão. Enfim, encarar de frente, civilizadamente ou "com tolerância" a nossa falta de respeito às diferenças, sejam elas étnicas, econômicas, religiosas, sociais e/ou políticas. Que tempo eram aqueles, ainda tão próximos de nós, "dos homens da revista Comentário"?

Uma afirmativa nos parece correta: a de que grande parte dos intelectuais que colaboravam com a Comentário foi fisgada pela ideia sedutora e muito própria de uma conjunção entre tempo/povo/lugar, capaz de aproximar culturas e promover o diálogo em todas as dimensões possíveis: étnica, religiosa, política, etc. No entanto - como nos tem demonstrado o passado e o presente - alcançar o diálogo e promover uma CULTURA DE PAZ exige muito mais do que uma [complexa] postura de tolerância para com o outro valorizando a diversidade. A postura deve ser de enfrentamento diante daquele que transforma em armas idéias e ações movidas pela intolerância e violência sem limites, apenas para citar algumas das situações possíveis.

Diante desta colocação, podemos considerar que a revista Comentário foi, durante seu curto tempo de existência, movida pelos ideais de combate á intolerância e de resistência a todas as formas de totalitarismo ou autoritarismo. Foi uma revista produzida por homens e mulheres de um mesmo tempo cujas ideologias e passado recentes, no caso de muitos judeus, não Ihes permitiam fazer quaisquer distinção de "raça", cor ou religião. A Shoah representou uma ferida aberta que ainda sangra, assim como o antissemitismo renovado, principalmente após a criação do Estado de Israel e as Guerras no Oriente Médio. 
As catástrofes promovidas na sequência de duas grandes guerras mundiais, assim como a situação de ditadura militar vivenciada pelo Brasil a partir de 1964, foram suficientes para sensibilizar um grupo de judeus e nãojudeus a criarem um movimento de resistência cultural e política que transformou a revista Comentário em seu órgão de opinião e de interferência na realidade. Aquele era o espaço que, apesar das condições de vigilância e repressão ditatoriais, e de ser mediado pela força diplomática e política do $A J C$, Ihes permitia refletir e agir em busca de tempos melhores, não tão "sombrios", como muito bem frisou Hannah Arendt em seus escritos. Por esse caminho da cultura procuraram (re)conhecer vestígios dos antigos e, portanto, solidificados registros que dão forma à civilização.

A geração de intelectuais que atua em Comentário pode ser classificada como particular na medida em que abraçou um mesmo projeto e, através dele, procurou moldar a sociedade quase que como uma conseqüência óbvia e imediata da dura realidade pós-Auschwitz. Cada qual, à sua maneira de olhar o mundo, procurou respostas para a intolerância, a violência, a miséria e a exclusão social. Como educadores, no sentido amplo da palavra, aceitaram o desafio de educar as novas gerações para a (co)existência. Como artistas, escritores, sociólogos, historiadores, economistas, psicólogos e poetas apenas para situar o perfil de alguns colaboradores - transformaram-se em tradutores do sentimento de horror diante da capacidade que os homens têm de (re)inventar o Mal.

Enfim, Comentário é um registro dos lemas e dilemas nacionais e do olhar de cada intelectual que registrou ali seu nome e suas idéias. Enquanto homens letrados defenderam "a verdade da qual se consideram os depositários" e fizeram escolhas.

A revista simboliza a resposta judaica de sobrevivência de uma cultura à tentativa de seu aniquilamento, uma reação que o erudito Chaim A. Kaplan descreve no seu Diário, do gueto de Varsóvia: "Tal como nosso ancestrais aprisionados no gueto continuaram a criar valores culturais, embora odiados e desprezados, assim faremos nós." ${ }^{387}$ Ou como enfatizou William Korey, ao tratar da persistência do antissemitismo na União Soviética em 1966: “(...) as

${ }^{387}$ Chaim A. Kaplan, “Um Diário do Gueto de Varsóvia”, In: Comentário, Ano VII, n. 2, p. 125. 
diversas práticas discriminatórias induziram muito judeus, principalmente entre os mais jovens, que já não falam iídiche e nada sabem da história e cultura judaicas, a tornar-se intensamente conscientes de seu judaísmo." ${ }^{388}$

O corpo editorial de Comentário conseguiu concentrar nas suas páginas a preocupação de um povo preocupado em resgatar as suas origens de forma a preservar a própria existência e identidade. Conseguiu também registrar um sentimento de luto judaico investido da tentativa de captura de uma atitude ocidental de culpa e de reparação das conseqüências herdadas do Holocausto.

A análise de Comentário nos coloca diante de uma geração de artistas e intelectuais dedicados a reencontrar uma posição estável no mundo através da construção "indefinida de novos discursos". O título da revista diz logo a que vem, pois pressupõe a criação de uma "possibilidade aberta de falar" aproximando-se da prática judaica de produzir Comentários a respeito dos textos sagrados. Falou-se de decepções políticas e situações que resultaram em angústias de perda, assim como do antissemitismo, de exclusão e de humilhação. A narrativa literária acerca da violência sem limites incitou-os a repetir o que já havia sido dito, ainda que com outras palavras e técnicas, mas que deveria ser sempre lembrado, retomando a definição de Comentário de Foucault, onde se diz "pela primeira vez aquilo que, entretanto, já havia sido dito e se repete incansavelmente aquilo que, no entanto, não havia jamais sido dito $389 "$, pois é da ordem inalcançável do real, impossível de simbolizar.

O florescimento do gênero teatral, o falar em ato pressupõe o desejo de tomada de posições novas então sufocadas e, portanto, suspensas. O desejo de se tornar outro. Os Direitos Humanos e suas características universalizantes foram de tal impacto que chegaram a ser comparados aos Dez Mandamentos ${ }^{390}$. Os judeus enquanto "povo do livro" cuja tradição é a de fazer leis, procura fazer valer seus princípios, muitos dos quais seculares. A conduta política liberal judaica tão associada à preservação do pluralismo e da valorização dos Direitos Humanos pensados a partir de um conjunto de

\footnotetext{
${ }^{388}$ Cf. William Korey, "A Lei Soviética e os Judeus", In: Comentário, Ano VII, n. 3, p. 221. O autor era diretor do Escritório do Conselho Internacional da B'nai B'rith de Nova lorque.

${ }^{389}$ Michel Foucault. A Ordem do Discurso. Trad. Laura Fraga de Almeida Sampaio. São Paulo Edições Loyola, 1996, pp 24.

390 Ver artigo de René Cassin, René Cassin, "Como lograr um mundo melhor", In: Comentário, n. 4, ano II, 1961, p. 363.
} 
princípios éticos e de justiça que permeiam o pensamento judaico ${ }^{391}$ pode ser encontrada na Declaração de Propósitos reproduzida em todos os números da revista.

Comentário nos oferece um panorama privilegiado das raízes do nosso presente que, em parte, expõem os motivos pelos quais ainda vivemos em um mundo intolerante e violento. Trata-se, em termos históricos, de um período não muito distante, mas o suficiente para o distanciamento de gerações que não vivenciaram a Segunda Guerra e que, portanto, não estão envolvidas diretamente com as questões ideológicas surgidas a partir dela. $\mathrm{O}$ "presente" para os produtores e autores da revista eram os anos de 1960 e 1970 cujas grandes questões encontram-se pontuadas na publicação. Foi nessa época que se estabeleceu o consenso quase que intimidador de hoje a respeito da democracia. A referência, é claro, eram os regimes totalitários, sobretudo o hitlerista responsável pelo extermínio de mais de seis milhões de judeus, milhares de ciganos, comunistas e outras minorias. Pairava no ar a idéia de que se a democracia não persistisse, os judeus cairiam para sempre.

No pós-guerra a democracia se estabeleceu enquanto tabu no discurso capitalista europeu e norte-americano visando assegurar-se de regimes que pudessem oferecer uma alternativa fosse para as ideologias de direita quanto para as de esquerda. Enquanto órgão de denúncia e combate a Comentário publicava artigos reproduzidos da sua "irmã" americana que frisavam a falta de liberdade para escrever na União Soviética. A insistência na liberdade editorial completa pela revista servia para opor-se ao amordaçamento da cultura que, no Brasil, também acontecia sob os olhares dos ditadores militares e cidadãos colaboracionistas. A lógica desse discurso democrático foi construída pela intelectualidade impregnando todas as áreas do pensamento, desde a religião, passando pela literatura e até a ciência e psicologia de modo que judaísmo e democracia foram aos poucos se amalgamando nas páginas de Comentário.

$\mathrm{Na}$ retórica antifascista e anticomunista persistia ainda o mito do complô ateu comunista contra a civilização ocidental representada pelos Estados Unidos que, durante a Guerra Fria, investiu contra o inimigo representado pela

391 A respeito de tais argumentos (substancialistas e posicionais) ver GRÜN, Roberto. "Identidade e Política: os judeus na esfera pública e a representação da comunidade." RBCS da ANPOCS, v. 26, n. 9, p. 123-148, 1994, p. 124, acessado através do site www.anpocs.org.br/ em 7/04/2008. 
União Soviética. Esse período exigiu um trabalho sistemático de associações judaicas principalmente americanas no sentido de afastar a imagem dos judeus da ideologia comunista largamente explorado pelo discurso maniqueísta do nazi-fascismo que os colocaram no pólo do mal, justificando o seu aprisionamento, humilhação e eliminação.

Os artigos publicados em Comentário nos esclarecem, em certos pontos, como o mito da conspiração judaica mundial - tão utilizado como instrumento de poder nas décadas de 1930 e 1940 - passou por transformações, típicas da lógica mítica que se assemelha à onírica, a partir do deslocamento dos antes articuladores do complô, os judeus, para o bloco oposto.

O AJC foi um dos grandes defensores da nação americana em função do papel representado pelos Estados Unidos no final da Segunda Guerra passando pela postura política liberal que aos poucos foi se delineando, pela ideologia capitalista (não sem passar antes pela crença numa sociedade democrática socialista). Os judeus enquanto americanos e vítimas dos expurgos stalinistas foram se convencendo de ser o grande modelo para 0 resto do mundo, até conquistarem, finalmente, o apoio dos Estados Unidos e Israel diante da crise no Oriente Médio.

O discurso de combate à conspiração comunista atéia, sempre comparado em nível maléfico ao nazismo (totalitarismo de esquerda e direita) foi abraçado pelo $A J C$ que, muito provavelmente, não contava com a metamorfose do mito. Ficam evidentes os desdobramentos do pensamento mítico por um antiamericanismo que se sucedeu à política imperialista norteamericana, esta sim de declarada dominação mundial. De artífices da Revolução de 1917 para capitalistas por excelência, assim se deu a nova demonização do judeu que contou com elementos de verossimilhança oriundos da defesa dos valores do Ocidente pelos judeus. Nessas circunstâncias, dentro da lógica mítica, os judeus permanecem em muitos discursos como agentes do complô.

Através da análise de Comentário procuramos identificar os dilemas, as escolhas e as reflexões que serviram de pano de fundo para esta iniciativa direcionada para o resgate cultural de uma geração, em grande parte, objeto e testemunha de "tempos sombrios". Muitos intelectuais - além daqueles do 
círculo de decisão editorial - que escreviam para a revista, faziam parte de Conselhos e órgãos estatais aproximando a plataforma da revista aos projetos políticos brasileiros e ocidentais de um modo geral. Mas em tempos de ditadura, tais aproximações exigem sempre precauções.

Assim, a revista Comentário registrou as utopias e as trajetórias destes intelectuais envolvidos com o seu projeto editorial elaborado no universo temporal da chamada Guerra Fria, uma guerra que teve a cultura como uma de suas armas. O discurso anticomunista, por exemplo, foi sendo incorporado na revista a partir de uma postura anti-stalinista. Talvez essa situação explique porque a revista tenha se sustentado - até alguns anos mesmo após o Al5, pois em nada feria a ideologia militarista no Brasil. Fica aqui parcialmente dito (sempre) que o caminho percorrido pela Comentário exigiu um extraordinário dispêndio de energia intelectual, produtora de profícuas reflexões e comentários, muitos deles marcos de combate e resistência contra a intolerância no seu sentido mais amplo. 
FONTES

$\underline{\text { Revista }}$

- Revista Comentário (Rio de Janeiro/ Brasil, 1960-1962; 1963 (n. 1); 1964-1967; 1968 (ns. 2,3,4); 1969; 1970; 1971), artigos utilizados citados nas Tabelas de Autores.

Fundos pessoais e comunitários

- Fundo Alfred Hirschberg: contém 84 caixas e permite o contato com uma variedade de documentos a respeito das instituições judaicas, seus objetivos e atividades em diferentes períodos. Consultamos: Revista Comentário (coleção); Caixas 6-10 - Documentação referente ao American Jewish Comittee - correspondência, alguns exemplares de Commentary Magazine; Caixa 61 - Instituto Brasileiro Judaico de Cultura e Divulgação (estatuto do Instituto, correspondência, artigos, revistas); Caixa 64 - Instituto Judio Argentino de Cultura e Informação (Revista Comentario - 1963 a 1970, artigos, relatórios), Revistas judaicas.

- American Jewish Year Book: disponibilizado em endereço virtual (www.ajarchives.org.) do período em que a revista circulou, onde estão contidas informações a respeito da comunidade judaica nos mais diversos países do mundo, inclusive no Brasil. Das informações constantes neste documento, a maioria do período em que circulou a revista, basicamente a década de 1960, era produzida pelo Dr. Alfred Hirschberg, cuja importância na organização da comunidade judaica no Brasil é substancial.

- American Jewish Committee (AJC): sob a guarda do AHJB representou rico material para esta pesquisa uma vez que é composta por relatórios, folhetos, boletins, memorandos, entre outros tipos documentais a respeito da atuação desta instituição de onde surgiu a revista Comentário.

\section{Documentos disponíveis on-line}

- "Elliot E. Cohen New Editor of AJC Record; Plan New Monthly Review for Fall of 1945", The Committee Reporter (maio de 1945). www.ajcarchives.org/ajarchive/DigitalArchive.aspx, acesso em 10/02/2010.

- "First Issue of AJC's New Monthly Commentary, to Appear Shortly". The Committee Reporter (outubro de 1945). www.ajcarchives.org/ajarchive/DigitalArchive.aspx, acesso em 10/02/2010. 
- $\quad$ The American Jewish Committee Memorandum from S. Andhil Fineberg to Eleanor Ashman, Subject: Brief Statement of AJC program on Communism, 1/08/1956, p. 1, In: www.ajcarchives.org/ajarchive/DigitalArchive.aspx, acesso em 10/02/2010.

- Press Release on the opening of the Israel Office, 14/02/1962, In: www.ajcarchives.org/ajarchive/Digitalrchive.aspx, acesso em 9/06/2010.

- Report on Anti-semitism in Argentina (confidential) by Julian H. Singman, setembro de 1962, The Amercan Jewish Committee, pp. 1-9, In: www.ajcarchives.org/ajarchive/DigitalArchive.aspx, acesso em 10/02/2010

- The American Jewish Committee Memorandum from Ralph Friedman, Chairman to Members of the Foreign Affairs Committee, Subject: Summary of special activities of AJC representatives in Latin America, 22/03/1960, In: www.ajcarchives.org/ajarchive/DigitalArchive.aspx, acesso em 10/02/2010, pp. 1-4.

- "Activities of the American Jewish Committee in Latin America", 5 de novembro de 1940, The Amercan Jewish Committee, p. 4 e 5, In: www.ajcarchives.org/ajarchive/DigitalArchive.aspx, acesso em 20/12/2010 e 25/02/2011.

- Israel/AJC Israel Office File, Foreign Affairs Department Collection, FAD1. Memoranda from William Frankel to Foreign Affairs Department on the question of establishing an office in Israel, 1947-1957, 14 de março de 1947, In: www.ajcarchives.org/ajarchive/DigitalArchive.aspx, acesso em 20/12/2010, p. 11.

- Mass Media/ Education Committee Minutes File, 8/03/1960, AJC Subject Files Collection. 1960 (9), p. 2, www.ajcarchives.org/ajarchive/DigitalArchive.aspx, acesso em 13/01/2011.

- Memorandum (personal and confidential) to John Slawson from Selma G. Hirsh, 3/04/1947, In: Political Philosophy/Communism Statements and Policy File, AJC Subject Files Collection. Memoranda and Policy Statements, 1947-1954 (6), pp. 1-3, In: www.ajcarchives.org/ajarchive/DigitalArchive.aspx, acesso em 25/02/2011.

- Cf. Program Statement of Foreign Affairs Department, pp. 1-15, 195x (ultimo n. ilegível), Israel/ AJC Israel Office File, Foreign Affairs Department Collection, FAD-1. Memoranda on the question of estabilishing an office in Israel, 1947-1957 (9), in: www.ajcarchives.org/ajarchive/DigitalArchive.aspx, acesso em 25/02/2011.

- Alfred Hirschberg, "Human Rights or Minority Rights", CJR, contents for February 1945, pp. 43-47, Jews \& Judaism/ File, AJC Subject Files Collection. Memoranda and reports on American Jewry. Included a report on the American Council for Judaism, 1945-1947. (4), In: www.ajcarchives.org/ajarchive/DigitalArchive.aspx, acesso em 01/03/2011.

- Minutes of Joint Meeting of Foreign Affairs Committee and Committee on Israel Commodore Hotel, 17/04/1959 (AJC 52 ${ }^{\text {nd }}$ Annual Meeting, Jews \& Judaism/ File, AJC Subject Fille Collection. Memoranda and reports on 
American Jewry. (4), In:

www.ajcarchives.org/ajarchive/DigitalArchive.aspx, acesso em 01/03/2011, pp. 1-3.

- Estatutos do Instituto Brasileiro e Judaico de Cultura e Divulgação, p. 1, Caixa 61, Instituto Brasileiro e Judaico de Cultura e Divulgação, Fundo Dr. Alfred Hirschberg, AHJB.

- Carta da Diretoria de Comentário para Sócio do Grupo Universitário Hebraico, Rio de Janeiro, agosto de 1961,1 p., encontrada solta dentro de uma das revistas que recebemos por doação do AHJB.

- Alfred Hirschberg e Abraham Monk, "Brasil", Foreign Coutries: Latin America, American Jewish Year Book (AJYB), Vol. 63, 1962, p. 480. In: http://www.ajcarchives.org/AJC DATA/Files/1962 16 LatinAmerica.pdf, acesso em 6/04/2011.

- Abraham Monk, "Brasil", Foreign Coutries: Latin America, American Jewish Year Book (AJYB), Vol. 64, 1963, p. 283. In: http://www.ajcarchives.org/AJC DATA/Files/1963 8 LatAmerica.pdf, acesso em 6/04/2011.

- Alfred Hirschberg, "Brasil", Foreign Coutries: Latin America, American Jewish Year Book (AJYB), Vol. 65, 1964, p. 190. In:

http://www.ajcarchives.org/AJC DATA/Files/1964 7 LatAmerica.pdf, acesso em 6/04/2011.

- Alfred Hirschberg, "Brasil", Foreign Coutries: Latin America, American Jewish Year Book (AJYB), Vol. 66, 1965, p. 341. In: http://www.ajcarchives.org/AJC DATA/Files/1965 8 LatAmerica.pdf, acesso em 6/04/2011.

- Cf. Alfred Hirschberg "Brasil", Foreign Coutries: Latin America, American Jewish Year Book (AJYB), Vol. 67, 1966, p. 298, 301-305. In: http://www.ajcarchives.org/AJC DATA/Files/1966 8 LatAmerica.pdf, acesso em 15/04/2011 e 16/04/2011.

- Alfred Hirschberg, "Brasil", Foreign Coutries: Latin America, American Jewish Year Book (AJYB), Vol. 68, 1967, p. 288. In: http://www.ajcarchives.org/AJC DATA/Files/1967 8 LatAmerica.pdf, acesso em 15/04/2011.

- Cf. George E. Gruen, “Nazism, Zionism, Antisemitism - The United Nations and the Arab-Israel Dispute - United States, Israel and The Middle East", United States: Communal, American Jewish Year Book (AJYB), Vol. 67, 1966, p. 263. In:

http://www.ajcarchives.org/AJC DATA/Files/1966 6 USCommunal.pdf, acesso em 14/04/2011.

- Cf. Alfred Hirschberg "Brasil”, Foreign Coutries: Latin America, American Jewish Year Book (AJYB), Vol. 69, 1968, p. 412. In:

- $\quad$ http://www.ajcarchives.org/AJC DATA/Files/1968 9 LatAmerica.pdf, acesso em 17/04/2011.

- Alfred Hirschberg "Brasil”, Foreign Coutries: Latin America, American Jewish Year Book (AJYB), Vol. 70, 1969, p. 308. In:

- http://www.ajcarchives.org/AJC DATA/Files/1969 7 LatinAmerica.pdf, acesso em 17/04/2011.

- Nissim Elnecave, "Argentina”, Foreign Coutries: Latin America, American Jewish Year Book (AJYB), Vol. 73, 1972, p. 436. In: 
http://www.ajcarchives.org/AJC DATA/Files/1972 8 LatinAmerica.pdf, acesso em 18/04/2011.

- Marcos Margulies, "Brasil", Foreign Coutries: Latin America, American Jewish Year Book (AJYB), Vol. 74, 1973, p. 326.. In:

http://www.ajcarchives.org/AJC DATA/Files/1973 7 LatinAmerica.pdf, acesso em 18/04/2011.

\section{Testemunhos Orais}

- Jacob Guinzburg, colaborador e o responsável pela edição da revista em São Paulo, professor aposentado da Escola de Comunicações e Artes da USP (11/04/2008)

- Boris Schnaiderman, colaborador e membro do conselho editorial da revista, professor aposentado da Faculdade de filosofia, Letras e Ciências sociais da USP (15/05/2009).

- Lizette Pernidji, viúva do Diretor da Revista no Brasil, o Sr. Joseph Eskenazi Pernidgi, advogado e escritor (por telefone, em maio de 2009 e pessoalmente na casa da entrevistada no Rio de Janeiro em 6/04/2010).

- Anita Novinsky, colaboradora e membro do corpo editorial da revista em São Paulo; professora aposentada do Departamento de História Social da Faculdade de Filosofia, Letras e Ciências Humanas da Universidade de Dão Paulo (por telefone em maio de 2009)

\section{Sítios e endereços eletrônicos}

- American Jewish Archives:

http://www.americanjewisharchives.org/

- Arquivo da revista Commentary:

http://www.commentarymagazine.com/

- Biografias:

Academia Brasileira de Letras:

http://www.academia.org.br/

Dicionário Histórico-Biográfico Brasileiro:

http://cpdoc.fgv.br/

Sítio de biografias vinculado à Universidade Federal de Campina Grande (UFCG):

http://www.dec.ufcg.edu.br/biografias

Oxford Chabad Society (Cecil Roth):

http://www.oxfordchabad.org/

Projeto Portinari:

http://www.portinari.org.br/

Enciclopédia Itaú Cultural - teatro:

www.itaucultural.org.br

Gladstone Chaves de Melo:

htp://www.filologia.org.br/ 
Joseph Eskenazi Pernidji:

http://www.eskenazi.com.br/cv1.asp, acesso em 27/04/2011.

Oscar Handlln:

http://www.harvardsquarelibrary.org/

Dicionário de Tradutores Literários no Brasil, Núcleo de Tradução da UFSC:

http://www.dicionariodetradutores.ufsc.brl, acessado em 22/02/2011.

- Boletim ASA:

http://www.asa.org.br/,

- Central Intelligence Agency:

https://www.cia.gov/

- Domínio Público:

http://www.dominiopublico.gov.br/

- Enciclopédia portuguesa de Direitos Humanos on line - Centro de

Direitos Humanos - lus Gentium Conimbrigae - Faculdade de Direito da Universidade de Coimbra:

http://www.fd.uc.pt/hrc/enciclopedia/index.html

- Revista Brasileira de Ciências Sociais (RBCS) da Associação Nacional de Pós-graduação e Pesquisa em Ciências Sociais (ANPOCS):

http://www.anpocs.org.br/

- World Jewish Congress:

http://www.worldjewishcongress.org/ 


\section{BIBLIOGRAFIA}

\section{OBRAS GERAIS E ESPECÍFICAS}

ALMEIDA, Maria das Graças Andrade Ataíde de. A Construção da Verdade Autoritária. São Paulo, Humanitas, FFLCH, 2001.

ANDERSON, Benedict. Nação e Consciência Nacional. São Paulo, Ática, 1989. ARENDT Hannah. Origens do totalitarismo. São Paulo, Companhia das Letras, 1989.

BALANDIER, Georges, A Desordem - Elogio ao Movimento. Ed. Bertrand do Brasil, 1997.

. O Poder em Cena. Brasília, ENB, 1982.

BARON, Salo H., História e Historiografia do Povo Judeu. São Paulo, Perspectiva, 1974.

BARTHES, Roland. Mitologias. Rio de Janeiro, Editora Bertrand Brasil, 1999.

BARRET-DUCROCQ, Françoise (dir.). A Intolerância. Foro Internacional sobre a Intolerância. UNESCO, 27 de março de 1997, Rio de Janeiro, Bertrand Brasil, 2000.

BEIRED, José Luis Bendicho. Sob o Signo da Nova Ordem - Intelectuais Autoritários no Brasil e na Argentina. São Paulo, Edições Loyola, 1999.

BHABHA, Homi K. O Local da Cultura. Belo Horizonte: Ed. UFMG, 1988.

BLAY, Eva Alterman, Judeus no Brasil: Política e cultura. V Congresso Internacional de Investigadores sobre Judaísmo. Buenos Aires, Argentina, 1988.

BOBBIO, N. Os intelectuais e o poder: dúvidas e opções dos homens de cultura na sociedade contemporânea. São Paulo, Editora UNESP, 1997.

BONAVIDES, Paulo e ANDRADE, Paes de. História Constitucional do Brasil. $3^{a}$ edição, Rio de Janeiro, Paz e Terra, 1991.

CANCELLI, Eliisabeth, O Brasil e os Outros - estranhamento, humilhação, memória e política. Trabalho apresentado para Concurso de livre-docência, Departamento de História - FFLCH/USP, 2008.

O Mundo da Violência: a Polícia da Era Vargas, Brasília, Editora Universidade de Brasília, 1993.

CAPELATO, Maria Helena Rolim e PRADO, Maria Lígia. O Bravo Matutino. Imprensa e Ideologia: O Jornal O Estado de São Paulo. São Paulo, Editora Alfa-Ômega, 1980.

São Paulo, Brasiliense, 1989.

Arautos do Liberalismo: Imprensa Paulista, 1920-1945, Imprensa e História do Brasil São Paulo, Contexto, 1988.

CARNEIRO, Maria Luiza Tucci. Brasil, um Refúgio nos Trópicos: A Trajetória dos Refugiados do Nazi-fascismo. São Paulo, Estação Liberdade, 1996.

O Veneno da Serpente. Reflexões sobre o Antissemitismo no Brasil. São Paulo, Editora Perspectiva, 2003.

- O Antissemitismo na Era Vargas. Fantasma de uma Geração (1930-1945). 3aㅡ edição, São Paulo, Editora Perspectiva, 2001.

. Cidadão do Mundo. O Brasil diante dos Judeus Refugiados

do Nazifascista, 1933-1948, São Paulo, Perspectiva, 2010. [Originalmente apresentada como Tese de Livre Docência em História à FFLCH, 2001] 
. Preconceito Racial e Brasil Colônia, São Paulo, Perspectiva:

2005

CARNEIRO, Maria Luiza Tucci; KOSSOY, Boris (orgs.) A Imprensa Confiscada pelo DEOPS, 1924-1954. São Paulo, Ateliê Editorial, 2003.

CARNEIRO, Maria Luiza Tucci; LAFER, Celso. Judeus e Judaísmo na Obra de Lasar Segall. São Paulo, Ateliê Editorial, 2004.

CHARTIER, Roger. A História Cultural: entre práticas e representações. Rio de Janeiro, Bertrand, 1990.

Práticas de Leitura. São Paulo, Estação Liberdade, 1996.

UNESP, 1998.

A Aventura do Livro: do leitor ao navegador. São Paulo,

CHAUÍ, Marilena, O que é Ideologia, São Paulo, Brasiliense, 1980.

Ideologia e Mobilização Popular. Rio de Janeiro, Paz e

Terra, 1978.

falas. São Paulo, Cortez, 1997.

Culura e Democracia: o discurso competente e outras

Brasil: mito fundador e sociedade autoritária, São Paulo,

Editora Perseu Abramo, 2000.

CLEMESHA, Arlene, Marxismo e Judaísmo - História de uma Relação Difícil. São Paulo, Boitempo Editorial, 1998.

CORRÊA, Maurício (presidente do STF). Crime de Racismo e AntissemitismoUm Julgamento Histórico do STF (Hábeas corpus no 82.424/RS). Brasília, Editora Brasília Jurídica, 2004.

DARNTON, Robert, Edição e Sedição -- o universo da literatura clandestina no séc. XVIII, São Paulo, Cia. das Letras, 1992.

A Revolução Impressa: A Imprensa na França: 1775-1800.

São Paulo, Edusp, 1996.

DOPS: a lógica da desconfiança, Rio de Janeiro, Secretaria de Estado de Justiça, Arquivo Público do Estado, 1996.

DUARTE, Paulo, História da Imprensa em São Paulo, Universidade de São Paulo, Ed. de Textos, 1973.

DULLES, J. W. F. O Comunismo no Brasil (1935-1945) Repressão em meio ao cataclismo mundial, Rio de Janeiro, Nova Fronteira, 1985.

FAGUNDES, Coriolano de Loiola Cabral, Censura e Liberdade de Expressão, São Paulo, Ed. do Autor, 1975.

FALBEL, Nachman. Manasche: sua Vida e seu Tempo. São Paulo, Perspectiva, 1996.

Edusp, 2008, p. 27.

Judeus no Brasil, Esutdos e Notas, São Paulo: Humanitas;

FAUSTO, Boris (dir.), História geral da civilização brasileira, O Brasil republicano, Sociedade e política (1930-1964), São Paulo, Difel, 1981, Tomo III, vol. 3.

(org.), Fazer a América. São Paulo, Edusp, 1999.

FEBVRE, Lucien, Combates pela História, Lisboa, Presença, 1977.

FERNANDES, Florestan, Ditadura em Questão, São Paulo, T A Queiroz, 1982.

FERRAZ JUNIOR, Tercio Sampaio. Introdução ao estudo do direito - técnica, decisão, dominação. São Paulo, Atlas, 1988.

FERRO, Marc. Os tabus da História. Rio de Janeiro, Ediouro, 2003

FOUCAULT, Michel. A Ordem do Discurso. Trad. Laura Fraga de Almeida Sampaio. São Paulo Edições Loyola, 1996. 
As Palavras e as Coisas: uma arqueologia das ciências humanas. São Paulo, Martins Fontes, 1996.

FREUD, Sigmund. "O Mal-Estar na Civilização (1930)", In: Obras Psicológicas Completas de Sigmund Freud: edição Standard Brasileira, Rio de Janeiro, Imago, 1996.

Aires, Amorrortu, $2^{a}$ ed., 2006.

FUKS,

GIRARDET, Raoul. Mitos e Mitologias Políticas. Trad. M. L. Machado. São Paulo, Companhia das Letras, 1987.

GOFFMAN, Erwin. Estigma - Notas Sobre a Manipulação da Identidade Deteriorada. Rio de Janeiro, LTC Editora, 1988.

GORENDER, Jacob. Combate nas Trevas. A Esquerda brasileira: das ilusões à luta armada, São Paulo, Ática, 1990.

GRAMSCI, Antonio. Os Intelectuais e a Organização da Cultura. Rio de Janeiro, civilização Brasileira, 1995.

GUINSBURG, Jacó (org), O Judeu e a Modernidade, São Paulo, Perspectiva, 1980.

HEALE, M. J. American Anticomunism: Combating the enemy within, 18301970. Baltimore, Johns Hopkins, 1990.

HERTZBERG, Arthur, Judaísmo, Zahar Editores, Rio de Janeiro, 1964.

HILTON, Stanley, Oswaldo Aranha - uma biografia. Rio de Janeiro, Objetiva, 1994.

HIRSCHBERG, Alice Irene, Desafio e Resposta, a História da Congregação Israelita Paulista, Edição especial por ocasião do quadragenário da Congregação Israelita Paulista, São Paulo, 1976.

HOBSBAWM, Eric, Era dos Extremos: o breve século XX (1914-1991), São Paulo: Cia. Das Letras, 1995.

IANNI, Octávio, A ideia de Brasil Moderno, São Paulo, Editora Brasiliense, 1996.

JANOTTI, Maria de Lourdes M. Os Subversivos da República. São Paulo, Brasiliense, 1986.

JAY, Martin. La Imaginacion dialética - Uma historia de La Escuela de Frankfur. Madri: Taurus, 1974.

JOHNSON, Paul. História dos Judeus. Rio de Janeiro, Editora Imago, 1995.

KOIFMAN, Fábio. Quixote nas trevas. O embaixador Souza Dantas e os Refugiados do Nazismo. Rio de Janeiro, Editora Record, 2002.

LEFORT, Claude, A invenção democrática: os limites do totalitarismo, São Paulo, Brasiliense, 1983.

LE GOFF, Jacques (e outros), História e Nova História, Lisboa, Teorema, 1986. LE GOFF, Jacques e NORA, Pierre, História: novos objetos, 3ª . ed., São Paulo, Livraria Francisco Alves Editora, 1988.

Martins Fontes, 1993.

"A História Nova", In: A História Nova, 2a․ ed., São Paulo,

História e Memória, 2ª . ed., Campinas, UNICAMP, 1992.

LESSER, Jeffrey. O Brasil e a Questão Judaica: imigração, diplomacia e preconceito. Trad. Marisa Sanematsu, Rio de Janeiro, Imago Editora, 1995.

MAGULIES, Marcos. Os Judeus na História da Rússia. Rio de Janeiro, Edições Bloch, 1971. 
MALAMUD, Samuel. Recordando a Praça Onze. Rio de Janeiro: Livraria Kosmos Editora, 1988.

MARTINS, Ana Luiza. Revistas em Revista. Imprensa e Práticas culturais em empós de República, são Paulo (1890-1922). São Paulo: Edusp, FAPESP, Imesp, 2001.

MARTINS, Wilson. História da Inteligência Brasileira. São Paulo: T. A. Querioz, 1996, v. 6 e 7.

MATOS, Olgária. Os Arcanos do Inteiramente Outro - Escola de Frankfurt Melancolia e Revolução. São Paulo: Brasiliense, 1996

MENDES - FLOHR, Paul R. and REINHARZ, Jehuda, The Jew in the Modern World, a Documentary History, Oxford University Press, New York, 1980.

MEIHY, José Carlos Sebe Bom. Manual de História Oral. São Paulo: Loyola, 2a ed., 1998.

MEIHY, José Carlos Sebe Bom. (org.). (Re)introduzindo história oral no Brasil. São Paulo: Xamã, 1996.

MICELI, Sergio. Intelectuais à brasileira, São Paulo, Cia das Letras, 2001.

MILGRAM, Avraham. Judeus do Vaticano: A tentativa de Salvação de Católicos Não Arianos da Alemanha ao Brasil através do Vaticano (1939-1942), Rio de Janeiro, Imago, 1994.

MILMAN, Luis (org.). Ensaios sobre o Antissemitismo Contemporâneo. Dos Mitos e da Crítica aos Tribunais. O Caso Siegfried Ellwanger e seus livros Neonazistas. Porto Alegre, Editora Sulina, 2004.

MIZRAHI, Rachel. Imigrantes Judeus do Oriente Médio - São Paulo e no Rio de Janeiro, São Paulo, Ateliê Editorial, 2003.

MOTA, Carlos Guilherme. Ideologia da Cultura Brasileira (1933-1974). São Paulo, Ática, 1978.

MOTTA, Rodrigo Patto Sá. Em Guarda contra o Perigo Vermelho: o Anticomunismo no Brasil (1917-1964). São Paulo, Perspectiva/FAPESP, 2002.

MOURA, Gerson, Sucessos e ilusões: relações internacionais do Brasil durante e após a II Guerra Mundial, Rio de Janeiro: FGV, 1991.

NOVINSKY, Anita Waingort e KUPERMAN Diane (orgs.). Ibéria-Judaica: Roteiros da Memória. São Paulo, EDUSP, 1996.

OLIVEIRA, Lúcia Lippi (org.). Elite Intelectual e Debate Político nos Anos 30: uma bibliografia comentada. Rio de Janeiro, FGV; Brasília, INL, 1980.

"As Raízes da Ordem: Os Intelectuais, A Cultura e O Estado". In: A Revolução de 30: Seminário Internacional. Seminário realizado pelo Centro de Pesquisa e Documentação de História Contemporânea do Brasil (CPDOC) da Fundação Getúlio Vargas, Brasília, Editora Universidade de Brasília, 1983.

ORTIZ, Carlos e GUINZBURG, Jacó. Antologia Judaica. São Paulo, Editora Rampa Ltda, 1948.

ORTIZ, Renato. Cultura Brasileira e Identidade Nacional. São Paulo, Brasiliense, 1994.

OS ARQUIVOS das Polícias Políticas: reflexos de nossa história contemporânea, Rio de Janeiro: FAPERJ, 1996.

PAILLET, Marc, Jornalismo - O Quarto Poder, São Paulo, Brasiliense, 1986.

PÉCAUT, Daniel. Os Intelectuais e a Política no Brasil: Entre o Povo e a Nação. São Paulo, Ática, 1990. 
PERAZZO, Priscila Ferreira. Os Súditos do Eixo" nos campos de concentração brasileiros (1942-1945), São Paulo, Humanitas/ Imprensa Oficial do Estado/ Fapesp, 2009.

. O Perigo Alemão e a repressão policial no Estado Novo, São Paulo, Arquivo do Estado/Imprensa Oficial, 1999.

PINKUSS, Fritz, Estudar Ensinar Ajudar: seis décadas de um rabino em dois continentes, Livraria Cultura Editora, $1^{\text {å }}$ edição: setembro de 1989.

PINSKY, Jayme, Origens do Nacionalismo Judaico, São Paulo, Hucitec, 1978.

POLIAKOV Léon. O mito Ariano. Trad. Luiz João Gaio. São Paulo, Perspectiva, Edusp, 1974.

. História do Antissemitismo I - De Cristo aos Judeus da Corte. São Paulo, Editora Perspectiva, 1979.

História do Antissemitismo II - De Maomé aos Marranos.

Trad. Ana M. Goldberger Coelho e J. Guinsburg. $2^{\text {a }}$ edição. São Paulo, Editora Perspectiva, 1996.

1933). São Paulo, Editora Perspectiva, 1985.

História do Antissemitismo IV - A Europa Suicida (1870Do anti-sionismo ao antissemitismo. São Paulo, Editora

Perspectiva, 2000.

PINSKY, Carla Bassanezi, Pássaros da Liberdade - Jovens, judeus e revolucionários no Brasil, São Paulo, Contexto, 2000.

POWERS, Richard Gids. Not without honor: the history of american anticommunism. Yale: Yale University Press, 1998.

PRESTES, Anita Leocádia et alii, Não olhe nos olhos do inimigo: Olga Benário e Anne Frank, Rio de Janeiro, Paz e Terra, 1995.

REIS FILHO, Daniel Aarão (org.). Intelectuais, História e Política: Séculos XIX e $X X$. Rio de Janeiro, 7 Letras, 2000.

Jorge Zahar, 2000.

Ditadura militar, esquerdas e sociedade. Rio de Janeiro,

SAID, Edward W. Representaciones del Intelectual. Barcelona, Ediciones Paidós, 1996.

SALIBA, Elias Thomé. As Utopias Românticas. São Paulo, Brasiliense, 1991.

SARLO, Beatriz. Tempo Passado: Cultura da Memória e Guinada Subjetiva. São Paulo: Companhia das Letras, Belo Horizonte: UFMG, 2007.

SARTRE, Jean-Paul. Em Defesa dos Intelectuais. São Paulo, Ática, 1994.

SAUNDERS, Frances Stonor. Quem pagou a conta? Rio de Janeiro, Record, 2008.

SCHIDT, A. e RUSCONI, G.E., La Scuola di Francoforte, Bari: De Donato editore, 1972

SEGATTO, José Antônio, Breve História do PCB, São Paulo, Liv. e ed. Ciências Humanas, 1981.

SELIGMANN-SILVA, M (org.). História, Memória, Literatura. O testemunho na era das catástrofes, Campinas: Editora da UNICAMP, 2003.

SEVCENKO, Nicolau. Literatura como Missão - Tensões Sociais e Criação Cultural na Primeira República. $2^{a}$ edição, São Paulo, Cia. Das Letras, 2003.

Orfeu Extático na Metrópole - São Paulo: sociedade e Cultura nos frementes anos 20, São Paulo, Cia das Letras, 1992.

SILVA, Silvia Cortez. Nos Tempos de Casa Grande, São Paulo, Perspectiva, 2009. [Originalmente Tese de Doutorado em História Social apresentada junto a FFLCH-USP, 1996]. 
SLATER, Phil. Origem e Significado da Escola de Frankfurt. Rio de Janeiro: Zahar Editores, 1978.

SODRÉ, Nelson Werneck. Do Estado Novo a Ditadura Militar: Memórias de Um Soldado, Petrópolis, Vozes, 1988.

civilização Brasileira, 1996. . Síntese da História da Cultura Brasileira. Rio de Janeiro,

Mauad, 1999. . Historia da Imprensa no Brasil, $4^{\mathrm{a}}$ edição, Rio de Janeiro,

SODRÉ, Roberto Costa de Abreu, No espelho do tempo: meio século de política, São Paulo, Ed. Best Seller, 1995.

SONTAG, Susan. A Doença como Metáfora e a Sida e as Suas Metáforas, Lisboa, Quertzal Editores, 1998.

TAKEUCHI, Marcia Yumi. O perigo amarelo em tempos de guerra, 1939-1945, São Paulo, Arquivo do Estado/ Imprensa Oficial do Estado, 2002

preconceito, São Paulo, Humanitas, 2008.

- O Perigo Amarelo: imagens do mito, realidade do

TODOROV, Tzvetan. Memória do Mal, Tentação do Bem. Indagações sobre o Século XX. Trad. Joana Angélica D’Ávila, São Paulo, Arx, 2002.

VERNANT, Jean-Pierre, Entre mito e política, São Paulo, Edusp, 2001.

VELTMAN, Henrique. A História dos Judeus em São Paulo. Rio de Janeiro, Editora Expressão e Cultura, 1996.

A História dos Judeus no Rio de Janeiro. Rio de Janeiro, Editora Expressão e Cultura, 1998.

VIEIRA, M.P.A. et alli, A Pesquisa em História, $2^{\underline{a}}$ edição, São Paulo, Ática, 1991.

WIAZOVSKI, Taciana. O mito do complô judaico comunista: gênese, difusão e desdobramentos (1907-1954). São Paulo: Humanitas, 2008. [Originalmente apresentada como Dissertação de mestrado, FFLCH, USP, Depto de Letras Orientais, 2005].

WIGGERHAUS, Rolf. Escola de Frankfurt - história, desenvolvimento teórico, significação política, tradução: Vera de Azambuja Harvey, Rio de Janeiro, Difel, 2002.

WINOCK, Michel. O Século dos Intelectuais. Rio de Janeiro, Bertrand Brasil, 2000.

WOLFF, Egon e Frieda. Guia Histórico da Comunidade Judaica de São Paulo, São Paulo, Editora B'nei B'rith S/C, 1988.

\section{BIOGRAFIAS}

PODHORETZ, Norman. Ex-Friends. Falling out with Allen Guinsberg, Lionel and Diana Trilling, Lillian Hellman, Hanna Arendt, and Norman Mailer. California: Encounter Books, 2000.

GROSS, Neil. Richard Rorty: The Making of an American Philosopher. Chicago: University of Chicago Press, 2008.

Coleção Os Pensadores - Adorno, São Paulo: Editora Nova Cultural, 1996.

\section{ARTIGOS}


ABRAMS, Nathan, "A Profoundly Hegemonic Moment: De-Mythologizing the Cold War New York Jewish Intellectuals". Shofar: An Interdisciplinary Journal of Jewish Studies - Volume 21, Number 3, Nebraska: University of Nebraska Press, Spring 2003, pp. 64-82.

BACZKO, Bronislaw. "Imaginário Social". In: Enciclopédia Einaudi, vol. 5, Lisboa, Imprensa Nacional/Casa da Moeda, 1985, pp. 296-330.

BELL, Daniel. "The Intelligentsia in American Society", In: Sociological Journeys: Essays 1960-1980, London: Heinemann, 1980, pp. 128-129.

CANCELLI, Elisabeth. "Intelectualidade e Poder: inconformidade na Guerra Fria, Revista ArtCultura, Uberlândia - MG, n. 9, jul-dez. de 2004, pp. 111-118.

DUMA, Jean. "Sobre as Elites: Abordagem Historiográfica". In Revista História UNISINOS. São Leopoldo: UNISINOS, Vol. $7^{\circ}$, n8: 89-103, jul/dez de 2003, p. 89-93.

ECO, Umberto. "Definições Léxicas". In: Françoise Barret-Ducrocq (dir.). A Intolerância, Foro Internacional sobre a Intolerância, UNESCO, 27 de março de 1997. Rio de Janeiro, Bertrand Brasil, 2000, pp. 15-19.

FALBEL, Nachman. "Crônica do Judaismo Paulista". In: Estudos Sobre a Comunidade Judaica no Brasil, São Paulo, F.I.S.E.S.P., 1984, pp. 107-117.

"Deus Absconditus: 'Yosl Rakover fala com Deus' de Zvi

Kolitz (Em memória dos mártires do Levante do Gueto de Varsóvia, 19 de abril de 1943)", Boletim Informativo do AHJB, Ano VII, no 27 - 1 Quadrimestre de 2003, 7-17.

"A imigração Israelita à Argentina e ao Brasil e a colonização agrária". In: Estudos sobre a comunidade judaica no Brasil, São Paulo, F.I.S.E.S.P., 1984, pp.37-61.

FEBROT, Luiz Izrael. "Os Clubes dos Judeus-comunistas de São Paulo Yuguent Club, Centro cultura e Progresso e Casa do Povo - Natureza e Objetivos". In: Boletim Informativo do AHJB, ano VII, n 28, 2003, pp. 19-26.

FONSECA, Guido, "Dops - um pouco de sua história", Revista Adpesp, São Paulo, dez./1989, ano 10, no 18.

GUERMAN, Michel. “'Ecos do Progressismo’: História e Memória da esquerda judaica dos anos 30 e 40". In: Boletim Informativo do AHJB, ano VI, no 24, 2002, pp. 19-23.

JACKSON, Luiz Carlos, A sociologia paulista nas revistas especializadas

(1940-1965). Tempo soc. [online]. 2004, vol.16, n.1, pp. 263-283. ISSN 0103-

2070. doi: 10.1590/S0103-20702004000100013, acesso em 7/1/2011.

JAY, Martin. "Os Judeus e a Escola de Frankfurt: teoria crítica e sua análise do anti-semitismo", In: VIEIRA, Nelson H. (org.). Construindo a imagem do Judeu: algumas abordagens teóricas. Rio de Janeiro: Imago Ed., 1994, pp. 91-117.

KINOSHITA, Dina Lida "O ICUF como uma rede de intelectuais", In: Revista UNIVERSUM, no 15, Universidad de Talca, 2000, pp. 377-398.

KUPERMAN, Esther. "ASA - Gênese e Trajetória da esquerda judaica não sionista carioca". In: Revista Espaço Acadêmico, no 28, Setembro de 2003, Mensal, ISSN 1519.6186 (www.espacoacademico.com.br, acessado em 9/5/2008 e 06/04/2011).

LINDGREN ALVES, J. A. "Excessos do Culturalismo: pós-modernidade ou americanização da esquerda?", Impulso - Revista de Ciências Sociais e Humanas: Modernidade e Pós-modernidade, n. 29, vol. 13, Piracicaba: Editora 
da UNIMEP, 2001, pp. 63-81.

(http://www.unimep.br/phpg/editora/revistaspdf/imp29art05.pdf, acessado em 14/01/2011).

MARTINS, Luciano. "A Gênese de uma Intteligentsia - Os Intelectuais e a Política no Brasil. 1920 a 1940". In: Revista Brasileira de Ciências Sociais (no 4), vol. 2, junho de 1987, pp. 65 e 87.

MEIER, Joseph B., "A Precious Legacy". In: The German-Jewish Legacy in America 1938-1988 - A Symposium, American Jewish Archives Journal, Volume XL, November, 1988, number 2, pp. 281-287.( http://americanjewisharchives.org/journal/PDF/1988 4002 00.pdf), acesso em 4/01/2011.

MENDES, Paulo Henrique Aguiar. "Metáfora/Metonímia e Discurso Político". In: PAIVA, Vera Lúcia Menezes de Oliveira e (org.). Metáforas do Cotidiano. Belo Horizonte, Universidade Federal de Minas Gerais, 1998, pp. 133-166.

PEREIRA, Mônica de S. Gouvêa França. 1987. Anhembi: criação e perfil de uma revista de cultura. Textos IDESP. Série História das Ciências Sociais, vol. 2.

SELIGMANN-SILVA, M. "Reflexões sobre a memória, a história e o esquecimento", In: M. Seligmann-Silva (org.) História, Memória, Literatura. O testemunho na era das catástrofes, Campinas: Editora da UNICAMP, 2003, pp. 59-89.

"Judeu-brasileiro: traduzindo um passado em um contexto hospitaleiro-hostil", In: Cadernos de Língua e Literatura Hebraica, n. 3, 2001 (pub. 2003). Pp. 321-336. Cadernos de Língua e Literatura Hebraica, Sao Paulo, v. n.3, p. 321-336, 2003.

M. "História como Trauma", Pulsional Revista de Psicanálise, S. Paulo, v. 116/7, p. 108-127, 1998

"Narrar o trauma - A questão dos testemunhos de catástrofes históricas", In: Psicologia Clínica, Vol. 20, n. 1, Rio de Janeiro, 2008, p. 2.

SENKMAN, Leonardo. "La política inmigratoria Del primer pernismo respecto de los refugiados de La postguerra: uma perspectiva comparada com Brasil, 1945-1954", In: GUREVICH, Beatriz e ESCUDÉ, Carlos (orgs.) El Genocídio ante La Historia y La Natureza Humana. Buenos Aires, Universidad Torcuato di Tella, Grupo Editor Latinoamericano, 1994, pp. 263-298.

TERRY, Diego. "Da Alemanha para o Rio", Boletim ASA n. 92, jan-fev. de 2005 em http://www.asa.org.br/boletim/92/92 h1.htm, acesso em 4/02/2011.

SENKMAN, Leonardo. "La Política inmigratória del Primer Peronismo Respecto de los Refugiados de la Postguerra: Uma Perspectiva Comparada com Brasil, 1945-1954". In: "O Brasil de Vargas e as relações diplomáticas com Israel: análise comparativa com a Argentina, 1949-1955". In: Norma Breda dos Santos, Brasil e Israel: Diplomacia e Sociedades, Brasília, Editora Universidade de Brasília, 2000, pp. 115-147.

SKLAROWSKY, Leon Frejda, "Crimes de Racismo - Crimes resultantes de discriminação ou preconceito de raça, cor, etnia, religião ou procedência nacional", disponível em http://www.movimentoafro.amazonida.com/crimes de racismo.htm, acessado em 21/01/2011.

WIAZOVSKI, T., "Elos de Solidariedade e Resistência: utopias da comunidade judaica paulista”, In: TUCCI CARNEIRO, M. L. (org.). São Paulo Metrópole das 
Utopias - Histórias de Repressão e Resistência no Arquivo Deops. São Paulo: Editora Lazuli/ Companhia Editora Nacional: 2009.

\section{OBRAS DE REFERÊNCIA}

ABBAGNANO, Nicola. Dicionário de Filosofia. Trad. Alfredo Bosi. $2^{\mathrm{a}}$ edição. São Paulo, Mestre Jou, 1962.

ABREU, Alzira Alves de, BELOCH, Israel (coords.), Dicionário Histórico Biográfico-Brasileiro pós-1930. 5 Vols. $2^{\mathrm{a}}$ edição. Rio de Janeiro, Editora da FGV, 2001.

BOBBIO, Norberto. Dicionário de Política. $4^{a}$ edição. Brasília, Editora da Universidade de Brasília, 1992, 2 vols.

CASHMORE, Ellis. Dicionário de Relações Éticas e Raciais. Tradução: Dinah Kleve. São Paulo, Summus, 2000.

HOLANDA, Aurélio Buarque de. O Novo Dicionário Aurélio da Língua Portuguesa. Versão atualizada e revista conforme o Novo Acordo Ortográfico da Língua Portuguesa de 7 de maio de 2008. Edição eletrônica Positivo Informática LTDA da 4a . Edição, 2009

HOUAISS, Antônio e VILLAR, Mauro de Salles, Dicionário Houaiss da Língua Portuguesa. $1^{\text {a }}$ edição, Rio de Janeiro, Editora Objetiva, 2001.

ROTH e outros - Enciclopédia Judaica - Editora Tradição S. A. Rio de Janeiro, 1967.

ROUDINESCO, Elisabeth e PLON, Michel. Dicionário de Psicanálise, Rio de Janeiro, Jorge Zahar Editor, 1998

\section{INVENTÁRIOS}

FALBEL, Nachman, Introdução ao Inventário Sumário do Fundo Dr. Alfred Hirschberg, AHJB: São Paulo: 1989, pp. 1-4.

WIAZOVSKI, Taciana., Bolchevismo e judaísmo: a comunidade judaica sob o olhar do DEOPS, Módulo VI - Comunistas Organizado por Maria Luiza Tucci Carneiro, São Paulo, Arquivo do Estado/Imprensa Oficial, 2001, 202pp. (Coleção Inventário DEOPS)

\section{CATÁLOGOS}

Maria Luiza Tucci Carneiro, 'Imagens de Israel por Portinari', In: Candido Portinari. Portinari em Israel. São Paulo, Centro de Cultura Judaica, 2010. Catálogo bilíngüe. 


\begin{tabular}{|c|c|c|}
\hline \multicolumn{3}{|c|}{ Comentário: Autores Nacionais ${ }^{393}$} \\
\hline $\begin{array}{l}\text { Nome, Data e } \\
\text { Lugar de } \\
\text { Nascimento }\end{array}$ & $\begin{array}{l}\text { Formação/Profissão/Carreira/ Reconhecimento social e } \\
\text { cultural/Obra }\end{array}$ & Artigos em Comentário \\
\hline $\begin{array}{l}\text { ANDRADE, Carlos } \\
\text { Drummond de. }\end{array}$ & Poeta brasileiro. Escreveu Antologia Poética; Lição de Coisas. & $\begin{array}{l}\text { 1. "Poemas", In: Comentário, Ano IV, no. 1, } \\
\text { 1963, p.48. }\end{array}$ \\
\hline $\begin{array}{l}\text { BALEEIRO, } \\
\text { Aliomar. }\end{array}$ & Deputado, professor de Direito, jurista e economista. & $\begin{array}{l}\text { 1. "O Velho tema da inflação", In: Comentário, } \\
\text { Ano III, no. } 3,1962 \text {, pp. 255-256. }\end{array}$ \\
\hline $\begin{array}{l}\text { BANDEIRA, } \\
\text { Manuel. }\end{array}$ & Poeta brasileiro. & $\begin{array}{l}\text { 1. "Horóscopo", poesia de André Gill traduzida } \\
\text { por Manoel Bandeira, In: Comentário, Ano I, } \\
\text { no․ 4, 1960, p. } 56 \text {. } \\
\text { 2. "A Mário Quintana”", poesia In: Comentário, } \\
\text { Ano VII, no. 4, 196, p. } 337 \text {. }\end{array}$ \\
\hline $\begin{array}{l}\text { BARATA, Mário } \\
1921 / 2007 \\
\text { (Rio de Janeiro/RJ } \\
-\quad \text { Rio de } \\
\text { Janeiro/RJ) }\end{array}$ & $\begin{array}{l}\text { Jornalista, crítico de arte, professor de História da Arte, estudou } \\
\text { Museologia, Ciências Sociais, História e Direito. Licenciou-se } \\
\text { em Letras e História da Arte na Sorbonne, diplomando-se, } \\
\text { ainda, em Ciências Políticas na Universidade de Paris. Foi } \\
\text { catedrático, por concurso, de História da Arte, da Escola de } \\
\text { Belas Artes da Universidade Federal do Rio de Janeiro. Integrou } \\
\text { o Conselho do Museu de Arte de São Paulo. Foi professor em }\end{array}$ & $\begin{array}{l}\text { 1. “'Nação Judaico-portuguesa' do Suriname e } \\
\text { suas relações com o Brasil, no século XVIII", } \\
\text { In: Comentário, Ano I, no. 1, 1960, pp. 54-57. } \\
\text { 2. “Atualidade e Expressão de Tarsila”, In: } \\
\text { Comentário, Ano IX, no‥ 2, 1968, pp. 112-116. }\end{array}$ \\
\hline
\end{tabular}

$\overline{392}$ Todas as informações a respeito dos autores e suas obras contidas nestas tabelas foram retiradas das revistas Comentário. Cabe frisar, no entanto, que nem todos os autores e artigos estão contidos nestas tabelas, que contemplam apenas auqeles citados no texto deste trabalho, com exeção dos primeiros anos da revista, completamente abarcados. Dados biográficos pesquisados em outras fontes foram devidamente citados em notas de rodapé.

${ }^{393}$ Classificamos como autores nacionais aqueles que, mesmo de origem estrangeira, escreveram para In: Comentário. Os internacionais se referem àqueles cujos artigos foram escritos para Commentary e reproduzidos na revista brasileira.

${ }^{394}$ Sobre Mario Barata, ver José Roberto Teixeira Leite, "Lembrança de Mario Barata”. In: 19\&20 - A revista eletrônica de DezenoveVinte. Volume III, n. 1, janeiro de 2008. Disponível em: http://www.dezenovevinte.net/19e20, acessada aos 20/10/2009 e DUAS TRAJETÓRIAS SENSÍVEIS, Correio da Bahia , 29/09/2007, nota reproduzida no site da Cosac Naify: www.cosacnaify.com.br/noticias/lausebarata.asp, acessado em 20/10/2009. 


\begin{tabular}{|c|c|c|}
\hline & $\begin{array}{l}\text { diversas universidades no Brasil e no exterior. Em 1946, foi um } \\
\text { dos fundadores do ICOM - International Council of Museums. } \\
\text { Organizador no Rio e em São Paulo da Seção Brasileira da } \\
\text { Association Internationali des Critiques d'Art (1949), da qual } \\
\text { seria vice-presidente e secretário regional para a América Latina } \\
\text { Participou de colóquios internacionais na Universidade de } \\
\text { Harvard, em } 1968 \text {. Foi colaborador efetivo do Hand-book of } \\
\text { Latin Americam Studies e da Biblioteca do Congresso, em } \\
\text { Washington, nos Estados Unidos. Foi Presidente de honra da } \\
\text { ABCA (Associação Brasileira de Críticos de Arte); Membro do } \\
\text { júri Internacional da IIIa Bienal de Paris e dos júris nacionais da } \\
\text { Bienal de São Paulo e Salão Nacional de Arte Moderna do Rio; } \\
\text { assessor para as artes na I Conferência Geral da UNESCO, em } \\
\text { 1945, em Paris. Teve Intensa atividade jornalística. Lançou o } \\
\text { Programa Crítica de Arte na Rádio Ministério da Educação e } \\
\text { Cultura. Escreveu A escultura de origem negra no Brasil (1957) } \\
\text { e Razões de ser e a importância da arte moderna (1958). }\end{array}$ & \\
\hline $\begin{array}{l}\text { BARRETO FILHO, } \\
\text { José. } \\
\text { 1908/1983 } \\
\text { (Aracaju/ SE - Rio } \\
\text { de Janeiro/RJ) }\end{array}$ & $\begin{array}{l}\text { Filósofo, ensaísta, poeta, romancista, crítico literário, educador, } \\
\text { advogado e político. Primo de Tobias Barreto. Participou, em } \\
1929 \text {, da fundação da Academia Sergipana de Letras, na } \\
\text { condição de sócio correspondente. Foi Deputado Federal - } \\
\text { 1935-1937). Ligado ao círculo de amigos e de intelectuais } \\
\text { vinculados ao pensamento de Jackson de Figueiredo do } \\
\text { movimento reacionário católico ou de renovação católica. A } \\
\text { partir de } 1937 \text { passou a advogar e lecionou psicologia } \\
\text { educacional na Universidade do Brasil, atual Universidade } \\
\text { Federal do Rio de Janeiro (UFRJ). De } 1962 \text { a } 1964 \text { foi membro } \\
\text { do Conselho Federal de Educação, órgão que presidiu, } \\
\text { integrando ainda a Comissão Geral de Investigações, instalada } \\
\text { logo após o movimento político-militar de abril de } 1964 \text { para } \\
\text { apurar denúncias de corrupção e subversão. Voltou a participar } \\
\text { do Conselho Federal de Educação entre } 1966 \text { e } 1968 .\end{array}$ & $\begin{array}{l}\text { 1. "Realidade norte-americana vista por } \\
\text { Maritain", In: Comentário, jan-fev-mar, 1960, n } \\
\text { 1, ano I, pp. 50-53 (resenha da obra Reflexões } \\
\text { sobre os Estados Unidos de Jacques Maritain. } \\
\text { Rio de Janeiro, Editôra Fundo de Cultura.). }\end{array}$ \\
\hline
\end{tabular}

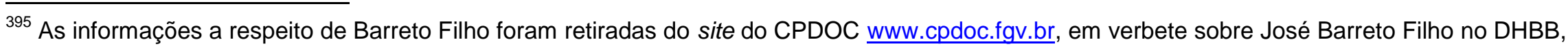
acessado em 14/02/2011. 


\begin{tabular}{|c|c|c|}
\hline & $\begin{array}{l}\text { Catedrático de psicologia educacional da Pontifícia } \\
\text { Universidade Católica do Rio de Janeiro - da qual foi fundador } \\
- \text { e do Instituto de Educação, foi ainda membro do Conselho } \\
\text { Nacional de Educação e da Ordem dos Advogados do Brasil. } \\
\text { Colaborou com jornais sergipanos antes de se mudar para o Rio } \\
\text { de Janeiro. No Rio de Janeiro: Hierarquia, Rio Jornal, O } \\
\text { Imparcial, O Brasil, O Sousa Cruz e O Norte do Rio de Janeiro. } \\
\text { Escreveu ensaios sobre Jackson de Figueiredo, Farias Brito e } \\
\text { Sílvio Romero. Publicou } \\
\text { Catedral de Ouro (1922); Sob o Olhar Malicioso dos Trópicos } \\
\text { (1929); Introdução a Machado de Assis (1947) }\end{array}$ & \\
\hline $\begin{array}{l}\text { BASSECHES, } \\
\text { Bruno. } \\
\text { (Rio de Janeiro/ } \\
\text { RJ - }\end{array}$ & Foi diretor das bibliotecas da Embaixada Americana. & $\begin{array}{l}\text { 1. "Achegas a uma bio-bilbiografia de Antônio } \\
\text { José da Silva", In: Comentário, 1961, n 1, ano } \\
\text { II, pp. } 84-90 \text {. }\end{array}$ \\
\hline $\begin{array}{l}\text { BENEDETTI, } \\
\text { Lúcia. }\end{array}$ & $\begin{array}{l}\text { Escritora. Romancista, contista e teatróloga. Escreveu } \\
\text { romances, contos e peças de teatro infantil. Romances: Entrada } \\
\text { de Serviço; Noturno sem Leito; Chão Estrangeiro e Três } \\
\text { Soldados. Contos: Vesperal com chuva. Peças de Teatro: O } \\
\text { Casaco Encantado, entre outras. }\end{array}$ & $\begin{array}{l}\text { 1. "O teatro infantil e seus problemas", } \\
\text { Comentário, 1960, n 3, ano I, pp. } 73-77 \text {. } \\
\text { 1. "O inferno de Rosauro tal como se deu", In: } \\
\text { Comentário, 1962, n 4, ano III, pp. 340-349. }\end{array}$ \\
\hline $\begin{array}{l}\text { BITTENCOURT, } \\
\text { Aluysio Régis. }\end{array}$ & Embaixador do Brasil em Israel em 1967. & $\begin{array}{l}\text { 1. "Brasil-Israel", In: Comentário, Ano VIII, n. 2, } \\
\text { 1967, pp. 101-103. }\end{array}$ \\
\hline BLOCH, Pedro. & $\begin{array}{l}\text { Médico, especialista em foniatria. Escritor. Escreveu contos, } \\
\text { argumentos cinematográficos, biografias, crônicas, obras de } \\
\text { divulgação cultural, peças de teatro traduzidas para vários } \\
\text { idiomas e representadas em diversos continentes. Recebeu } \\
\text { Medalha de ouro da crítica como "o melhor autor de 1951", } \\
\text { "Prêmio Arthur Azevedo" da ABL e Medalha de Ouro da } \\
\text { Sociedade Brasileira de Autores Teatrais. Peças: As mãos de } \\
\text { Euridice; Dona Xêpa,; Os inimigos não mandam flores; Morre } \\
\text { um gato na China, entre outras. }\end{array}$ & $\begin{array}{l}\text { 1. O Sorriso de Pedra (Peça em dois Atos), In: } \\
\text { Comentário, 1960, n } 3 \text {, ano I, pp. 49-64. } \\
\text { INÉDITA. } \\
\text { 2. "O Espetáculo não pode parar", In: } \\
\text { Comentário, revista trimestral, Ano III, no. 1, } \\
\text { jan-fev-mar, 1962, pp. } 67-72 \text {. }\end{array}$ \\
\hline $\begin{array}{l}\text { BOAL, Augusto } \\
\text { Pinto } \\
1931 / 2009 \\
\text { (Rio de Janeiro/RJ }\end{array}$ & $\begin{array}{l}\text { Diretor de teatro, autor e teórico. Cursou direção e dramaturgia } \\
\text { na Universidade de Columbia, em Nova lorque. Obteve o } \\
\text { Prêmio Sacy como melhor autor de } 1959 \text { com a peça } \\
\text { "Revolução na América do Sul" e o Sacy e a Medalha de Ouro }\end{array}$ & $\begin{array}{l}\text { 1. “A Arte Inoportuna", In: Comentário, 1964, n } \\
\text { 1, ano ,V, pp. 46-50. }\end{array}$ \\
\hline
\end{tabular}




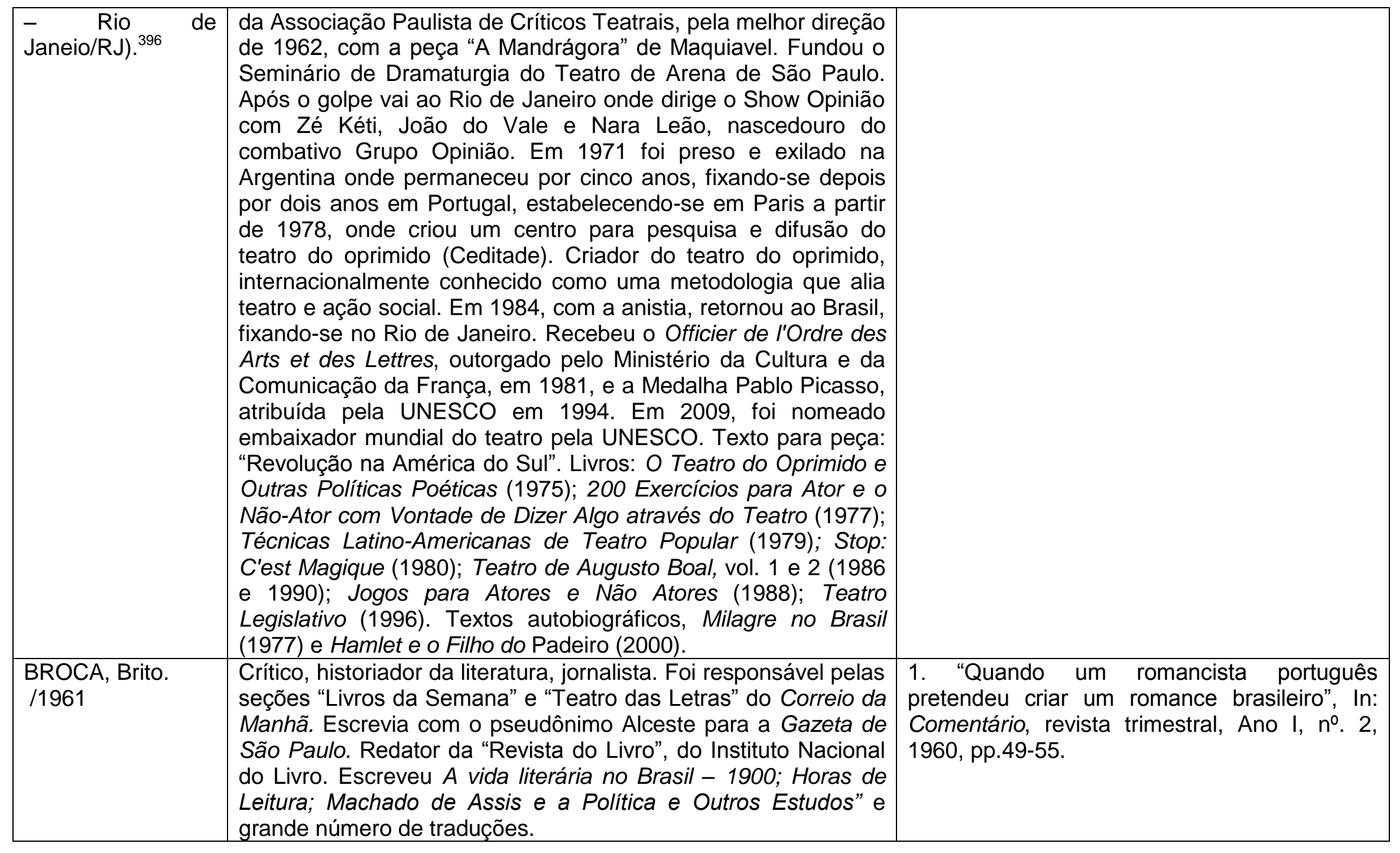

${ }^{396}$ Sobre o dramaturgo consultamos a enciclopédia de teatro do sítio www.itaucultural.org.br, acessado em 04/04/2011. 


\begin{tabular}{|c|c|c|}
\hline BURLÁ, Eliezer. & Professor de comunicações da PUC. & $\begin{array}{l}\text { 1. "Visão Geral e generalizada do Parque } \\
\text { Industrial Brasileiro", In: Comentário, Ano VIII, } \\
\text { no․ } 11967 \text {, pp. 11-14. } \\
\text { 2. "75 milhões de jovens estão lá", In: } \\
\text { Comentário, Ano VIII, no. } 2 \text { 1967, pp. 110-113.. }\end{array}$ \\
\hline CARO, Herbert. & $\begin{array}{l}\text { Intelectual formado na Alemanha e radicado em Porto Alegre. } \\
\text { Dicionarista. Tradutor. Foi representante de Comentário em } \\
\text { Porto Alegre. Traduziu: Buddenbrook e A Montanha Mágica. } \\
\text { Autor de Balcão de Livraria, coletânea de artigos sobre } \\
\text { problemas de cultura publicados pelo Serviço de Documentação } \\
\text { do Ministério da Educação e Cultura. }\end{array}$ & $\begin{array}{l}\text { 1. "A mãe brasileira de Thomas Mann", In: } \\
\text { Comentário, Ano I, no. } 3,1960 \text {, pp.65-72. } \\
\text { 2. "A "Reparação Moral" em duas Exposições } \\
\text { Alemãs", In: Comentário, Ano III, nNo. 1, 1962, } \\
\text { pp.52-62. }\end{array}$ \\
\hline $\begin{array}{l}\text { CASCUDO, Luís } \\
\text { da Câmara. (RN) }\end{array}$ & $\begin{array}{l}\text { Pesquisador e especialista em folclore com destaque para o } \\
\text { Nordeste e a África. Professor, figura pública. Fundou } \\
\text { organizações de natureza cultural, entre elas, o Instituto de } \\
\text { Música. Recebeu distinções de associações em várias partes } \\
\text { do mundo. Publicou diversos livros. }\end{array}$ & $\begin{array}{l}\text { 1. "Motivos Israelitas na Tradição Brasileira", } \\
\text { In: Comentário, Ano VII, noo. 1, 1966, pp.15-27. }\end{array}$ \\
\hline $\begin{array}{l}\text { CASTRO, Paulo } \\
\text { de. (Portugal/) }\end{array}$ & $\begin{array}{l}\text { Intelectual socialista e antifascista que vivia no Brasil. Escreveu } \\
\text { para a seção de política internacional do Diário de Notícias. }\end{array}$ & $\begin{array}{l}\text { 1. "Depoimento sobre o nasserismo", In: } \\
\text { Comentário, Ano III, №. 2, 1962, pp. 165-176. }\end{array}$ \\
\hline CHEN, Arieh. & $\begin{array}{l}\text { Brasileiro que residia em Israel e acompanhava a evolução do } \\
\text { teatro naquele país. }\end{array}$ & $\begin{array}{l}\text { 1. "Anatomia do Teatro Israelense", In: } \\
\text { Comentário, Ano II, no. 1, 1961, pp. 36-45. }\end{array}$ \\
\hline $\begin{array}{l}\text { CONRADO, } \\
\text { Aldomar. } \\
\text { (Recife } \\
\text { Pernambuco/) }\end{array}$ & $\begin{array}{l}\text { Fromado em Direito, Filosofia e Dramaturgia. Recebeu o Prêmio } \\
\text { de Teatro do Governo de Pernambuco pela peça O livro de } \\
\text { Davi, menção honrosa de autor no II Festival Nacional de Teatro } \\
\text { de Estudantes em Santos com } A \text { Grade Solene e o Prêmio } \\
\text { Curso de Teatro da Escola de Belas Artes da Universidade do } \\
\text { Recife com A Grande Noite de Olívia. Peças: Os Peregrinos; } \\
\text { Um Verão para sempre. }\end{array}$ & $\begin{array}{l}\text { 1. "A imensa janela do mundo", In: } \\
\text { Comentário, Ano IV, no. 1, 1963, pp. 103-107. }\end{array}$ \\
\hline $\begin{array}{l}\text { CORÇÃO, } \\
\text { Gustavo. }\end{array}$ & $\begin{array}{l}\text { Pensador católico. Engenheiro e professor. Escrevia no Diário } \\
\text { de Notícias. Escreveu Três Alqueires e uma vaca, Lições de } \\
\text { Abismo, Dez Anos. }\end{array}$ & $\begin{array}{l}\text { 1. "Um amigo de verdade", In: Comentário, } \\
\text { Ano II, no. } 1,1961 \text {, pp. 65-67. }\end{array}$ \\
\hline CUNHA, Octacilio. & $\begin{array}{l}\text { Vice-almirante. Foi Professor da Escola Naval e da Escola } \\
\text { Técnica do Exército e membro da Academia Brasileira de } \\
\text { Ciências. Presidiu a Comissão de Construção de Bases Navais, } \\
\text { A Comissão Organizadora do Curso de Engenharia de } \\
\text { Construção Naval de Energia Nuclear. Foi Presidente do }\end{array}$ & $\begin{array}{l}\text { 1. "Problemas do desenvolvimento Científico } \\
\text { no Brasil", In: Comentário, Ano III, №. 1, 1962, } \\
\text { pp. 35-41. }\end{array}$ \\
\hline
\end{tabular}




\begin{tabular}{|c|c|c|}
\hline & Conselho Nacional de Pesquisas. & \\
\hline $\begin{array}{l}\text { CUNHA, Ovidio } \\
\text { da. }\end{array}$ & $\begin{array}{l}\text { Estudioso da Geografia Humana. Foi docente de Economia } \\
\text { Política da Universidade Federal do Estado do Rio. Dedicou-se } \\
\text { é Sociologia Econômica situando-se na corrente estruturalista. }\end{array}$ & $\begin{array}{l}\text { 1. "Perspectivas de Atualização das Estruturas } \\
\text { Sociais nas Sociedades Subdesenvolvidas", } \\
\text { In: Comentário, Ano VI, no. 1, 1965, pp. 29-33. }\end{array}$ \\
\hline $\begin{array}{l}\text { FERNANDES, } \\
\text { Florestan } \\
\text { 1920/1995 } \\
(\text { São Paulo/ SP - } \\
\text { São Paulo/ SP) }\end{array}$ & $\begin{array}{l}\text { Sociólogo. Catedrático da Faculdade de Filosofia, Ciências e } \\
\text { Letras da USP em 1964. Recebeu em } 1948 \text { o Prêmio Fábio } \\
\text { Prado por sua tese de mestrado sobre a organização social dos } \\
\text { Tupinambá. Envolveu-se na década de } 1950 \text { no Programa de } \\
\text { Pesquisa sobre Relações Raciais no Brasil, patrocinado pela } \\
\text { UNESCO. Sua pesquisa demarcou uma nova visão do estudo } \\
\text { do negro. Preso durante o movimento civil-militar de } 1964 \text { lutou } \\
\text { contra o regime realizando palestras em defesa da } \\
\text { democratização da sociedade. Foi afastado da USP em } 1969 \text { e } \\
\text { aposentado pelo Ato Institucional no } 5 \text { (Al-5). Transferiu-se para } \\
\text { os Estados Unidos onde lecionou na Universidade de Colúmbia } \\
\text { e na Universidade de Toronto, até 1972. Vinculado à } \\
\text { Universidade de Yale de 1975 a 1978, retornou ao Brasil e } \\
\text { tornou-se professor da Pontifícia Universidade Católica de São } \\
\text { Paulo. Em 1986 foi eleito deputado federal constituinte pelo PT. } \\
\text { Ocupou diversos cargos políticos. Participou do processo de } \\
\text { elaboração, discussão e aprovação da Lei de Diretrizes e Bases } \\
\text { da Educação Nacional, iniciado em 1988. Foi reeleito em } \\
\text { outubro de } 1990 \text {. Ao longo das décadas de 1980 e } 1990 \\
\text { publicou vários livros centrados na conjuntura política. Recebeu } \\
\text { o título de doutor honoris causa da Universidade de Coimbra } \\
\text { (1990). Em 1943 começou a colaborar com os jornais } \\
\text { paulistanos: O Estado de S. Paulo e Folha da Manhã; Folha de } \\
\text { São Paulo (coluna regular de } 26 \text { de junho de 1989 a } 7 \text { de } \\
\text { agosto de 1995). Escreveu A organização social dos Tupinambá } \\
\text { (1949); Negros e brancos em São Paulo (1955); A etnologia e a } \\
\text { sociedade brasileira: ensaios sobre aspectos da formação e } \\
\text { desenvolvimento das ciências sociais no Brasil (1958); artigo: "A } \\
\text { ciência social e a educação como fatores de mudança cultural }\end{array}$ & $\begin{array}{l}\text { 1. "A Educação como problema social", In: } \\
\text { Comentário, Ano I, no. 4, 1960, pp. 7-13. }\end{array}$ \\
\hline
\end{tabular}

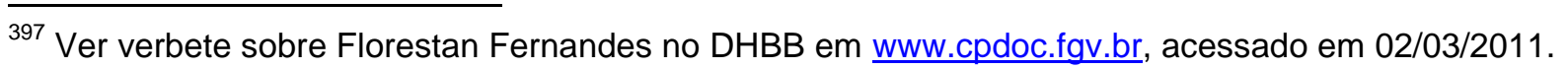




\begin{tabular}{|c|c|c|}
\hline & $\begin{array}{l}\text { provocada"; A sociologia numa era de revolução social (1962); } \\
\text { Fundamentos empíricos da explicação sociológica (1967); } \\
\text { Capitalismo dependente e classes sociais na América Latina } \\
\text { (1973); entre outros }\end{array}$ & \\
\hline \begin{tabular}{ll|} 
FIGUEIREDO, & \\
Guilherme & de \\
Oliveira & \\
$1915-1997$ & \\
(Campinas/SP & - \\
Rio & de \\
Janeiro/RJ) &
\end{tabular} & $\begin{array}{l}\text { Dramaturgo, romancista, poeta, crítico de música e teatro, } \\
\text { advogado e jornalista. Irmão do último presidente militar João } \\
\text { Figueiredo. Começou trabalhando em jornais cariocas com } \\
\text { crítica teatral em O Jornal e literária no Diário de Notícias. } \\
\text { Estreou como dramaturgo com LADY GODIVA e GREVE } \\
\text { GERAL em 1948. Suas peças eram em geral, cômicas e de } \\
\text { temática grega (mitologia). Destaque para UM DEUS DORMIU } \\
\text { LÁ EM CASA (1949), com Paulo Autran e Tônia Carreiro, no } \\
\text { elenco de amadores e dirigida por Silveira Sampaio. Traduziu } \\
\text { Moliére, Shakespeare, Bernard Shaw, entre outros. Lecionou } \\
\text { história do teatro na Escola do Serviço Nacional de Teatro } \\
\text { desde 1949. A RAPOSA E AS UVAS (1952), recebeu diversos } \\
\text { prêmios e foi sua criação mais conhecida no Brasil e no exterior. } \\
\text { Foi encenada no décimo aniversário da República Socialista da } \\
\text { China. Publicou Tratado Geral dos Chatos (1962), com a ajuda } \\
\text { de Graciliano Ramos, tornando-se conhecido nacionalmente.A } \\
\text { RAPOSA E AS UVAS, dirigida por Bibi Ferreira, no exterior } \\
\text { conheceu diversas encenações e traduções e recebeu OS } \\
\text { prêmios municipal do Rio de Janeiro e da Associação Brasileira } \\
\text { de Críticos Teatrais (ABCT). UM DEUS DORMIU LÁ EM CASA } \\
\text { foi premiada pela ABL e recebeu a medalha de ouro da ABCT. } \\
\text { Contribuiu para O Jornal (RJ) e Diário de Notícias (RJ). Poesias: } \\
\text { Um Violino nas Sombras (1936). Montagens teatrais: LADY } \\
\text { GODIVA e GREVE GERAL (1948); UM DEUS DORMIU LÁ EM } \\
\text { CASA (1949); A RAPOSA E AS UVAS (1952); MENINA SEM } \\
\text { NOME (1957); A MUITO CURIOSA HISTÓRIA DA VIRTUOSA } \\
\text { MATRONA DE ÉFESO (1958). Romance: Tratado Geral dos } \\
\text { chatos (1962), O outro lado do rio. }\end{array}$ & $\begin{array}{l}\text { 1. "O Princípio de Arquimedes - Ato único", In: } \\
\text { Comentário, Ano I, no. 1, janeiro, fevereiro e } \\
\text { março de 1960, seção 'No Prelo', pp. } 60-66 \text { - } \\
\text { INÉDITA. } \\
\text { 2. "Meu Tio Alfredo - Peça em Um Ato", In: } \\
\text { Comentário, Ano II, no } 4 \text { (8), out-nov-dez de } \\
\text { 1961, pp. 331-339 - INÉDITA. }\end{array}$ \\
\hline FRANCO, Afonso & Jurista. Professor. Político. Ensaísta. Memorialista. Historiador. & 1. "A Discriminação Racial em Face da Lei e \\
\hline
\end{tabular}

$\overline{398}$ Sobre Guilherme Figueiredo consultamos a enciclopédia de teatro do sítio www.itaucultural.org.br, acessado em 17/02/2011. 


\begin{tabular}{|c|c|c|}
\hline $\begin{array}{l}\text { Arinos de Melo. } \\
1905 / 1990 \\
\text { (Belo Horizonte - } \\
\text { MG/ Rio de } \\
\text { Janeiro - RJ) }\end{array}$ & $\begin{array}{l}\text { Crítico. Filho de Afrânio de Melo Franco e Sylvia Alvim de Melo } \\
\text { Franco. Família tradicional. Linhagem de políticos e destacados } \\
\text { na vida pública. Sobrinho do escritor e regionalista Afonso } \\
\text { Arinos. Autor da lei AFONSO ARINOS contra a discriminação } \\
\text { racial (Lei 1390, de } 3 \text { de julho de 1951). Senador (eleito em } \\
\text { 1958), pelo antigo Distrito Federal, RJ. Redigiu o capítulo sobre } \\
\text { a declaração de direitos e garantias individuais da Constituição } \\
\text { de 1967. Ministro das Relações Exteriores nomeado por Jânio } \\
\text { Quadros em 1961, desenvolveu uma política de aproximação } \\
\text { dos países do bloco socialista. Partidário do Golpe militar de } \\
1964 \text {. Um dos fundadores da Arena. Crítico dos rumos do } \\
\text { regime, abandonou a política em 1967, voltando em } 1986 \text { como } \\
\text { senador. Membro da ABL. Sócio efetivo do IHGB. Professor } \\
\text { Emérito da UFRJ e UERJ. Membro do Conselho Federal de } \\
\text { Cultura (1967 e 1973). Dirigiu os jornais O Estado de Minas e } \\
\text { Diário da Tarde. História. Política. Direito. Mémórias. Críticas. } \\
\text { Trabalhos Parlamentares. Discursos. Conferências. Prefácios. } \\
\text { Autor de: O índio brasileiro e a Revolução Francesa. }\end{array}$ & $\begin{array}{l}\text { do Sentimento Brasileiros", In: Comentário, } \\
\text { 1960, n 1, ano I, pp. } 7 \text { e } 8 .\end{array}$ \\
\hline $\begin{array}{l}\text { GIKOVATE, } \\
\text { Moisés. }\end{array}$ & $\begin{array}{l}\text { Geógrafo paulista, sócio correspondente do Instituto Geográfico } \\
\text { e Histórico da Bahia. Autor de obras didáticas. }\end{array}$ & $\begin{array}{l}\text { 1. "Brasília - Ideologia e Revolução - o ciclo } \\
\text { da civilização do interior", In: Comentário, Ano } \\
\text { I, №. 3, 1960, pp. 9-15. } \\
\text { 2. "Encontros com Kafka", In: Comentário, Ano } \\
\text { XI, no. 1, 1971, pp. 69-75. }\end{array}$ \\
\hline ISMAEL, J. C. & $\begin{array}{l}\text { Crítico de cinema desde 1953. Colaborava com as revistas } \\
\text { Divulgação, Música, Revista do DCE da PUC - SP e com o } \\
\text { Suplemento Literário dO Estado de São Paulo. Havia sido } \\
\text { assessor de cinema da Universidade Católica de São Paulo. }\end{array}$ & $\begin{array}{l}\text { 1. "Caminhos do Cinema Moderno", In: } \\
\text { Comentário, Ano V, no. 3, 1964, pp. 251-254. }\end{array}$ \\
\hline $\begin{array}{l}\text { KELLY, Prado } \\
\text { 1904/1986 } \\
\text { (Niterói/RJ-Rio de }\end{array}$ & $\begin{array}{l}\text { Advogado. Político. Empresário. Filho de Otávio Kelly, deputado } \\
\text { estadual no Rio de Janeiro (1907-1909) e, ministro do STF } \\
\text { (1934-1942). Irmão de Celso Otávio do Prado Kelly, presidente }\end{array}$ & $\begin{array}{l}\text { 1. "O Preconceito Racial e as Declarações de } \\
\text { Direitos do Homem", In: Comentário, Ano I, no. } \\
\text { 4, out-nov-dez, 1960, pp. 21-23. }\end{array}$ \\
\hline
\end{tabular}

\footnotetext{
${ }^{399}$ As informações a respeito de Afonso Arinos foram retiradas do site da ABL http://www.academia.org.brl, acessado em 30/09/2009 e do CPDOC
} http://www.cpdoc.fgv.br/comum/htm/, em 'Biografias', acessado em 07/10/2009. 


\begin{tabular}{|c|c|}
\hline Janeiro/RJ) ${ }^{400}$ & $\begin{array}{l}\text { da ABI (1965) e secretário de Educação do estado da } \\
\text { Guanabara(1972). José Eduardo do Prado Kelly estudou na } \\
\text { Faculdade de Direito da Universidade do Rio de Janeiro e } \\
\text { ingressou na política por ocasião da campanha da Aliança } \\
\text { Liberal, pra eleger Getúlio Vargas presidente da República. } \\
\text { Ocupou diversos cargos políticos, foi deputado das } \\
\text { Constituintes de } 1933 \text { e } 1946 \text { e de outras legislaturas ordinárias. } \\
\text { Em 1937, opondo-se ao regime estadonovista, afastou-se da } \\
\text { política, atuando como advogado. Com a redemocratização } \\
\text { retornou à política. Foi diretor-vice-presidente da Companhia } \\
\text { Docas de Santos (1948-1975), presidente da UDN (1948), } \\
\text { membro da Comissão de Constituição e Justiça da Câmara dos } \\
\text { Deputados (1955-1959), Ministro da Justiça e Negócios } \\
\text { Interiores (1955), presidente do conselho da OAB, seção Distrito } \\
\text { Federal (1956). Em 1959 encerrou sua carreira política. } \\
\text { Representou o Brasil na Conferência Interamericana pela } \\
\text { Manutenção da Paz e Segurança no Continente (1959). Foi } \\
\text { presidente do conselho federal da OAB (1960-1962), ministro do } \\
\text { Supremo (1964-1968) e empresário (1968-1975). Em 1973 foi } \\
\text { eleito membro da Comissão Jurídica Interamericana pela } \\
\text { Assembléia Geral da Organização dos Estados Americanos } \\
\text { (OEA), reeleito em 1974. Recebeu Prêmio da ABL pelo livro de } \\
\text { poesias Alma das coisas (1921). Prêmio Machado Portela em } \\
\text { 1925 (aluno que mais se destacara durante o curso de } \\
\text { graduação). Em 30 de junho de 1981 tomou posse na Academia } \\
\text { Carioca de Letras. Foi redator do jornal A Noite (1925-1930). } \\
\text { Livros de poesias: Poesias (1930) e Crônicas de nossos dias } \\
\text { (1937). Direito: Usufruto e fideicomisso (1931), Correição e } \\
\text { poder disciplinar (1938), Direito constitucional (1966) e Missão } \\
\text { do advogado (coletânea de discursos, 1977). Política: Estudos } \\
\text { de ciência política (3v., 1965 e 1966) e Fascínio da democracia } \\
\text { (ensaios, } 1977) \text {. Publicou conferências, discursos }\end{array}$ \\
\hline
\end{tabular}

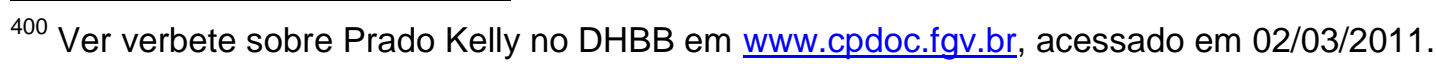




\begin{tabular}{|c|c|c|}
\hline & $\begin{array}{l}\text { parlamentares, estudos jurídicos, pareceres e artigos em } \\
\text { revistas, especialmente na Revista Forense e na Revista da } \\
\text { Academia Fluminense de Letras. }\end{array}$ & \\
\hline $\begin{array}{l}\text { LEITE, José } \\
\text { Roberto Teixeira. }\end{array}$ & Foi Diretor do Museu Nacional de Belas-Artes. & $\begin{array}{l}\text { "Reflexões sôbre a pop art", In: Comentário, } \\
\text { Ano VII, n. 3, 1966, pp. 253-259. }\end{array}$ \\
\hline $\begin{array}{l}\text { LEITE, Luiza } \\
\text { Barreto. }\end{array}$ & $\begin{array}{l}\text { Atriz. Crítica de teatro do Jornal do Comércio. Assessora de } \\
\text { teatro do C.N.C. Professora de Estética e Interpretação da } \\
\text { Escola de Dança do Estado da Guanabara. Professora de } \\
\text { Interpretação do Conservatório Nacional de Teatro. Fundadora } \\
\text { de "Os Comediantes". }\end{array}$ & $\begin{array}{l}\text { 1. "As mulheres no teatro brasileiro", In: } \\
\text { Comentário, ANO V, n. 2, 1964, pp. 118-132. }\end{array}$ \\
\hline LESSA, Orígenes. & $\begin{array}{l}\text { Escritor. "Mestre do conto". Ampla bibliografia. Destaque para O } \\
\text { Feijão e o Sonho e Rua do Sol. }\end{array}$ & $\begin{array}{l}\text { 1. "Colher de Chá", In: Comentário, Ano II, no. } \\
\text { 2, 1961, pp. 159-162. }\end{array}$ \\
\hline $\begin{array}{l}\text { LIMA, } \\
\text { Amoroso. }\end{array}$ & $\begin{array}{l}\text { Também conhecido pelo pseudônimo de Tristão de Athayde. } \\
\text { Pensador, líder católico, publicista, crítico literário, professor de } \\
\text { literatura. Dirigiu o Centro Dom Vital e a revista católica } A \\
\text { Ordem. }\end{array}$ & $\begin{array}{l}\text { 1. "Eduardo Prado", In: Comentário, Ano II, no. } \\
\text { 2, 1961, pp. 119-123. }\end{array}$ \\
\hline $\begin{array}{l}\text { LIMA, Geraldo } \\
\text { França de. }\end{array}$ & $\begin{array}{l}\text { Educador, advogado. Era assistente da Procuradoria da } \\
\text { República do Distrito Federal e da Consultoria Jurídica do } \\
\text { Ministério da Educação. }\end{array}$ & $\begin{array}{l}\text { 1. "Com Bernanos no Brasil - Dezenove anos } \\
\text { depois", In: Comentário, Ano I, no.. 2, 1960, } \\
\text { Seção "Registro", pp. 74-82. }\end{array}$ \\
\hline LINS, Osman. & $\begin{array}{l}\text { Escritor. O visitante; Os gestos; Lisbela e o prisioneiro; Os } \\
\text { animais enjaulados; O Fiel e a pedra. }\end{array}$ & $\begin{array}{l}\text { 1. "Um parisiense extranumeral", In: } \\
\text { Comentário, Ano III, n. 4, 1962, Seção "No } \\
\text { prelo", pp. } 362-366 .\end{array}$ \\
\hline $\begin{array}{l}\text { LISBOA, } \\
\text { Henriqueta. }\end{array}$ & Poetisa. Escreveu: Lírica (1958) & $\begin{array}{l}\text { 1. “Opção”, In: Comentário, Ano II, no. 1, 1961, } \\
\text { p. 46, INÉDITA. }\end{array}$ \\
\hline $\begin{array}{l}\text { LISPECTOR, } \\
\text { Clarice. }\end{array}$ & Escritora. & $\begin{array}{l}\text { 1. "A Criança e o Professor", In: Comentário, } \\
\text { Ano II, no } 1,1961 \text {, pp. 73-77, conto INÉDITO. }\end{array}$ \\
\hline MAGALDI, Sábato. & $\begin{array}{l}\text { Crítico teatral de O Estado de São Paulo. Professor da Escola } \\
\text { de Arte Dramática de São Paulo. Escreveu Panorama do Teatro } \\
\text { Brasileiro }\end{array}$ & $\begin{array}{l}\text { 1. "Perspectivas do Teatro Brasileiro", In: } \\
\text { Comentário, Ano III, no. 3, 1962, pp. 274-278. } \\
\text { INÉDITO. }\end{array}$ \\
\hline $\begin{array}{l}\text { MATTA, Roberto } \\
\text { da. }\end{array}$ & $\begin{array}{l}\text { Antropólogo. Trabalhou no Museu Nacional. Estudou na } \\
\text { Universidade de Harvard entre 1963-64, onde se especializou } \\
\text { nos grupos indígenas Jê-Timbira (Gaviões e Apinayé). }\end{array}$ & $\begin{array}{l}\text { 1. "Edgar Allan Poe, o ‘bricoleur': um exercício } \\
\text { em análise simbólica", In: Comentário, Ano, } \\
\text { VI, n. } 3,1965 \text {, pp. } 236-246 \text {. }\end{array}$ \\
\hline Mc DERMOTT, A. & $\begin{array}{l}\text { Irlandês, que como técnico de moagem trabalhou em moinhos } \\
\text { do Rio de Janeiro e da Bahia por muitos anos. Escreveu sobre o }\end{array}$ & $\begin{array}{l}\text { 1. "Um Continente em Evolução visto por } \\
\text { dentro", In: Comentário, Ano II, no. 1, 1961, pp. }\end{array}$ \\
\hline
\end{tabular}




\begin{tabular}{|c|c|c|}
\hline & $\begin{array}{l}\text { ambiente político na Rodésia e Niassalândia, enquanto vivia na } \\
\text { Rodésia do Sul. }\end{array}$ & 7-20. \\
\hline $\begin{array}{l}\text { MEIRELES, } \\
\text { Cecília. }\end{array}$ & $\begin{array}{l}\text { Escritora. Poetisa. Tradutora do escritor hindu Rabindranath } \\
\text { Tagore. }\end{array}$ & $\begin{array}{l}\text { 1. "A imortalidade de Rabindranath Tagore", } \\
\text { In: Comentário, Ano II, no. 3, 1961, pp. 219- } \\
\text { 230. } \\
\text { 2. "Rimancim para Lélia Frota", In: } \\
\text { Comentário, ANO VIII, n. 3, 1967, p. } 263 .\end{array}$ \\
\hline $\begin{array}{l}\text { MELO, Gladstone } \\
\text { Chaves de }(1917- \\
\text { 2001), mineiro }{ }^{401}\end{array}$ & $\begin{array}{l}\text { Crítico literário e linguista (ou filólogo, cf. debate a respeito). } \\
\text { Atuou no ensino, na política, no jornalismo e na diplomacia. Na } \\
\text { década de } 1940 \text { desenvolveu estrito convívio com Alceu } \\
\text { Amoroso Lima que o apoiou ao lado de outros sócios do Centro } \\
\text { Dom Vital para vereador pela UDN, eleito em 1950. Era } \\
\text { vereador (reeleito) na época em que escreveu o primeiro texto } \\
\text { para Comentário. Professor da PUC. Um dos líderes do Partido } \\
\text { Democrata Cristão. Foi deputado estadual do Estado da } \\
\text { Guanabara. }\end{array}$ & $\begin{array}{l}\text { 1. "Alceu Amoroso Lima, o Laureado do Ano", } \\
\text { In: Comentário, Ano I, no. 1, 1960, Seção } \\
\text { "Registro", pp. 79-83. }\end{array}$ \\
\hline $\begin{array}{l}\text { MIRA Y LOPEZ, } \\
\text { Emilio. }\end{array}$ & $\begin{array}{l}\text { Professor do campo da psicologia, psiquiatria e psicotécnica. } \\
\text { Doutorou-se em Medicina pela Faculdade de Madri. Ministrou } \\
\text { aulas e conferências nas principais universidades do mundo. } \\
\text { Mudou-se para o Brasil em 1945, onde fundou o Instituto de } \\
\text { Seleção e Orientação Profissional. Escreveu Guia da Saúde } \\
\text { Mental, Psicologia da Vida Moderna, quatro Gigantes da Alma. }\end{array}$ & $\begin{array}{l}\text { 1. "Visão Geral da Psicologia", In: Comentário, } \\
\text { Ano V, no. . 1, 1964, pp. 17-23. }\end{array}$ \\
\hline $\begin{array}{l}\text { MONTEIRO, } \\
\text { Adolfo Casais, } \\
\text { português. }\end{array}$ & $\begin{array}{l}\text { Escritor. Conferencista ministrou cursos universitários e } \\
\text { colaborou com a imprensa no Brasil. Romance: Adolescentes } \\
\text { (1946); Poesia: Versos (1945); Crítica literária: O Romance e } \\
\text { seus problemas (1950); Estudo e Antologia: A Poesia da } \\
\text { Presença. }\end{array}$ & $\begin{array}{l}\text { 1. "Pensamento e Ação de Anísio Teixeira", In: } \\
\text { Comentário, Ano II, no. 2, 1961, pp. 135-138. }\end{array}$ \\
\hline $\begin{array}{l}\text { MOREIRA, } \\
\text { Roberto. }\end{array}$ & $\begin{array}{l}\text { Diretor de Programa do Centro Brasileiro de Pesquisas } \\
\text { Educacionais, Prof. Visitante da Graduate School of Education } \\
\text { da Universidade de Chicago, técnico de educação do Ministério } \\
\text { de Educação e Cultura, diretor do Projeto de estudos e }\end{array}$ & $\begin{array}{l}\text { 1. "Analfabetismo e Subdesenvolvimento", In: } \\
\text { Comentário, Ano II, no. 2, 1961, pp. 103-109. }\end{array}$ \\
\hline
\end{tabular}

${ }^{401}$ Sobre Gladstone Chaves de Melo ver João Alves Pereira Penha, Gladstone Chaves de Melo (1917-2001); Elvo Clemente, Gladstone Chaves de Melo e Márcia Sipavicius Seide, "Gladstone Chaves de Melo - filólogo ou linguista?" In: Cadernos do CNLF, Série VII, $n^{\circ} 05$ - Homenagem a Gladstone Chaves de Melo, em htp://www.filologia.org.br/viicnlf/anais/caderno05.html, acessado em 22/10/2009. 


\begin{tabular}{|c|c|c|}
\hline & $\begin{array}{l}\text { Pesquisas sobre Educação e Desenvolvimento, no Centro } \\
\text { Latinoamericano de Pesquisas em Ciências Sociais, da } \\
\text { UNESCO. Escreveu: Educação e Desenvolvimento no Brasil; } \\
\text { Teoria e Prática da Escola Elementar, Education and society in } \\
\text { Brazil, The Story of Education in Brazil. }\end{array}$ & \\
\hline $\begin{array}{l}\text { OLIVERIA, } \\
\text { Roberto Cardoso } \\
\text { de. }\end{array}$ & $\begin{array}{l}\text { Antropólogo. Professor de Antropologia. Foi Diretor da Divisão } \\
\text { de Antropologia do Museu Nacional e Secretário da Associação } \\
\text { Brasileira de Antropologia. Também foi membro do Conselho } \\
\text { Diretor do Instituto de Ciências Sociais da Universidade do } \\
\text { Brasil e do Conselho Nacional de Proteção aos Î́ndios. Ministrou } \\
\text { cursos de pós-graduação e de aperfeiçoamento no Museu } \\
\text { Nacional e no Centro Brasileiro de Pesquisas Educacionais. } \\
\text { Suas pesquisas em etnologia geraram artigos e livros. Entre os } \\
\text { quais citamos: O Processo de Assimilação dos Terêna (1960); } \\
\text { O Índio e o Mundo dos Brancos: a situação dos Tukúna do Alto } \\
\text { Solimões (1964); Identidade, Etnia e Estrutura Social (1976). }\end{array}$ & $\begin{array}{l}\text { 1. "O Índio na Consciência Nacional", In: } \\
\text { Comentário, Ano VI, n. 2, pp. 126-131. }\end{array}$ \\
\hline $\begin{array}{l}\text { PASSOS, } \\
\text { Claribalte. }\end{array}$ & $\begin{array}{l}\text { Compositor. Sócio-fundador-proprietário da Orquestra Sinfônica } \\
\text { Brasileira. }\end{array}$ & $\begin{array}{l}\text { 1. "Música Popular Brasileira", In: Comentário, } \\
\text { Ano, VIII, n. 1, 1967, pp. 35-40. }\end{array}$ \\
\hline PILOTO, Valfrido. & $\begin{array}{l}\text { Escritor, jornalista, poeta, memorialista e ensaísta. Foi membro } \\
\text { da Academia Paranaense de Letras. Escreveu: Sintonias e } \\
\text { discordâncias (Curitiba, 1959); Páginas de Casa, Do Diário de } \\
\text { um Tempo Ruim, Minhas Memórias do Modernismo. }\end{array}$ & $\begin{array}{l}\text { 1. "Anne Frank, A Menina-mártir", In: } \\
\text { Comentário, Ano II, no. 2, 1961, pp. 173-175. } \\
\text { 2. "A Veneranda Esperança de Russel", In: } \\
\text { Comentário, Ano VI, №. 2, 1965, pp. 139-146. }\end{array}$ \\
\hline PIÑON, Nelida. & $\begin{array}{l}\text { Escritora. Foi editora-assistente da revista Cadernos Brasileiros. } \\
\text { Escreveu: Guia-Mapa de Gabriel Arcanjo; Madeira Feita Cruz; } \\
\text { Tempos das Frutas; Primogênito dos Mortos. Pela Teatral: } \\
\text { Beatas do Nojo. }\end{array}$ & $\begin{array}{l}\text { 1. "Menino Doente", In: Comentário, Ano IV, } \\
\text { no. 1, 1965, pp. 66-69. }\end{array}$ \\
\hline $\begin{array}{l}\text { PINTO, Lúcio A. } \\
\text { de Costa. }\end{array}$ & $\begin{array}{l}\text { Professor de Sociologia na Universidade do Brasil, Diretor do } \\
\text { Centro Latino-Americano de Pesquisas Sociais adjunto à } \\
\text { UNESCO. Escreveu: O Negro no Rio de Janeiro; Luta de } \\
\text { Famílias no Brasil; As ciências Sociais no Brasil, Migrações } \\
\text { Internas no Brasil, entre outros. }\end{array}$ & $\begin{array}{l}\text { 1. "A Opressão Racial na África do Sul" In: } \\
\text { Comentário, Ano I, no. 3, 1960, pp. 5-8. }\end{array}$ \\
\hline PONTES, Joel & $\begin{array}{l}\text { Professor da Faculdade de Filosofia e do curso de teatro da } \\
\text { Universidade do Recife. Descrito em Comentário como crítico } \\
\text { militante. Escreveu: "O aprendiz de crítica" }\end{array}$ & $\begin{array}{l}\text { 1. "Recife: um centro de renascimento teatral } \\
\text { no Brasil", In: Comentário, Ano I, n. 4, 1960, } \\
\text { pp. } 75-79 \text {. }\end{array}$ \\
\hline ROSA, & Consagrado escritor brasileiro traduzido em diversos idiomas. & 1. "Pirlimpsiquice", seção "contos", In: \\
\hline
\end{tabular}




\begin{tabular}{|c|c|c|}
\hline Guimarães. & $\begin{array}{l}\text { Escreveu: "Sagarana", "Corpo de Baile", "Grande Sertão: } \\
\text { Veredas", "Primeiras Estórias", entre outras }\end{array}$ & $\begin{array}{l}\text { Comentário, Ano III, n. 3, 1962, pp. 264-269. } \\
\text { INÉDITA }\end{array}$ \\
\hline $\begin{array}{ll}\text { TELLES, } & \text { Lygia } \\
\text { Fagundes } & \end{array}$ & $\begin{array}{l}\text { Escritora. Premiada em } 1958 \text { com "Histórias do Desencontro" } \\
\text { como a melhor obra no gênero 'conto' pelo Instituto Nacional do } \\
\text { Livro. Contos citados em Comentário: "Praia Viva" e "O Cacto } \\
\text { Vermelho". Romance: Ciranda de Pedra. }\end{array}$ & $\begin{array}{l}\text { 1. "As Cerejas", conto, In: Comentário, Ano I, } \\
\text { n. } 2,1960 \text {, pp. } 69-73 . \\
\text { 2. "Os objetos", conto, In: Comentário, Ano X, } \\
\text { n. } 1,1969, \text { pp. } 60-63 .\end{array}$ \\
\hline $\begin{array}{l}\text { PORTINARI, } \\
\text { Cândido } \\
1903 / 1962 \\
\text { (Brodowski/SP } \\
\text { Rio } \\
\text { Janeiro/RJ) }\end{array}$ & 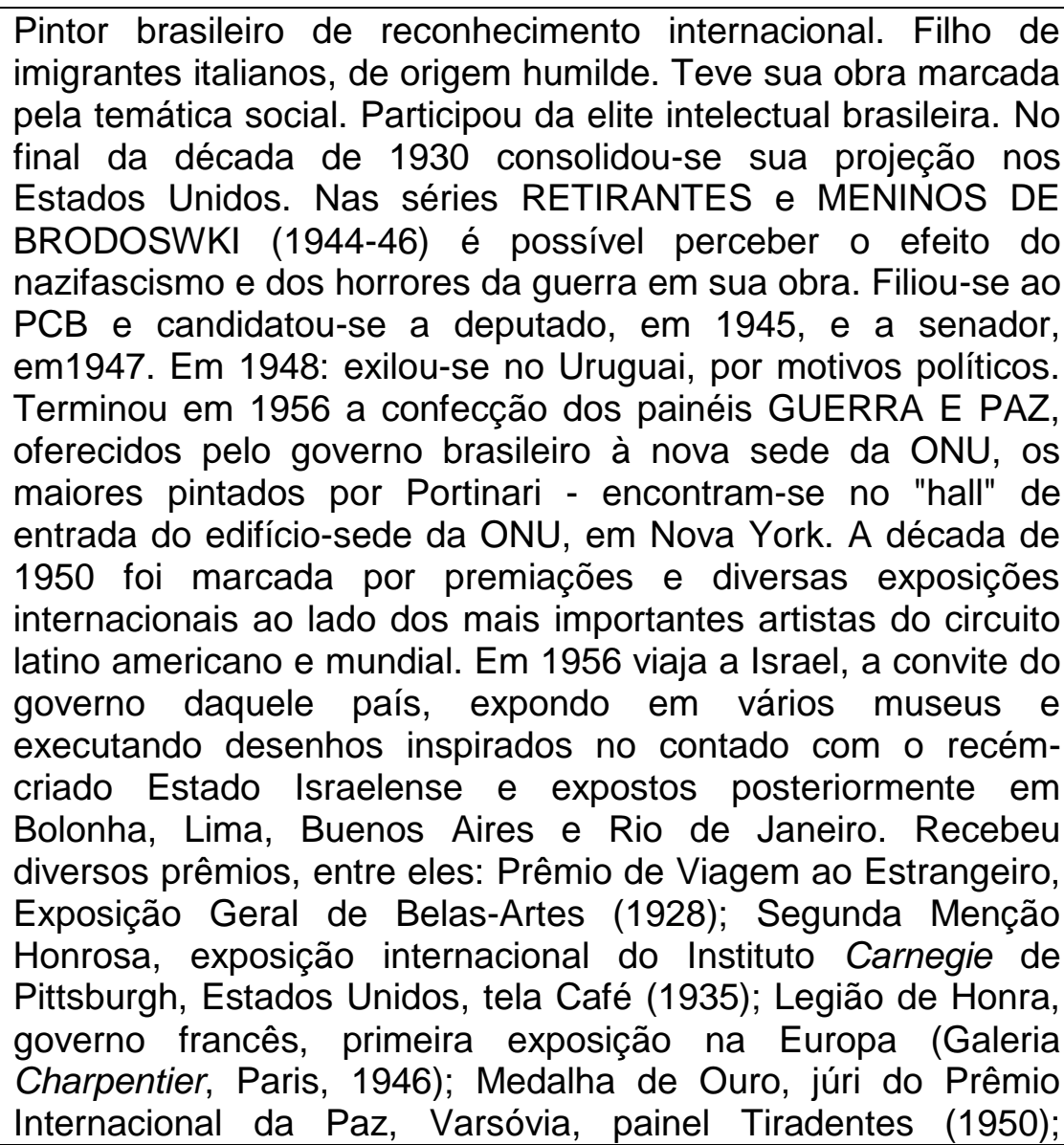 & $\begin{array}{l}\text { 1. Duas poesias: "A Beduína" - Jerusalém, } \\
\text { junho de } 1956 \text { e "Os Retirantes" - Paris, } \\
\text { outubro de } 1958 \text {, In: Comentário, revista } \\
\text { trimestral, Ano I, no. 1, janeiro, fevereiro e } \\
\text { março de 1960, pp. 58-59 (compaixão, } \\
\text { Oriente, retirantes do Norte). INÉDITAS. }\end{array}$ \\
\hline
\end{tabular}

$\overline{402}$ Dados do autor retirados de http://www.casadeportinari.com.br/poeta.htm, acessado em 21/10/2009. 


\begin{tabular}{|c|c|c|}
\hline & $\begin{array}{l}\text { Medalha de Ouro, International Fine Arts Council de Nova York, } \\
\text { melhor pintor do ano (1955); Prêmio Guggenheim do Brasil } \\
\text { (1956); Menção Honrosa no Concurso Internacional de } \\
\text { Aquarelas do Hallmark Art Award, de Nova York (1957); Único } \\
\text { artista brasileiro a participar da exposição '50 Anos de Arte } \\
\text { Moderna', no Palais des Beaux Arts, em Bruxelas (1958). Tela: } \\
\text { CAFÉ (1935). Painéis: O MORRO (1939); SÉRIE BÍBLICA } \\
\text { (1943); SÃO FRANCISCO e VIA SACRA (1944); RETIRANTES } \\
\text { E MENINOS DE BRODOWSKI (1944-46); A PRIMEIRA MISSA } \\
\text { NO BRASIL (1948); TIRADENTES (1949); A CHEGADA DA } \\
\text { FAMÍLIA REAL PORTUGUESA À BAHIA (1952); GUERRA E } \\
\text { PAZ (1956). } \\
\text { Poesias. }\end{array}$ & \\
\hline $\begin{array}{ll}\text { SASSI, } & \text { Guido } \\
\text { Wilmar. } & \end{array}$ & $\begin{array}{l}\text { Regionalista ficcionista de Lajes, Santa Catarina. Com o } \\
\text { romance São Miguel venceu o concurso literário organizado } \\
\text { pelas Edições Melhoramentos e o Círculo da Boa Leitura. } \\
\text { Escreveu: Piá (1953), Amigo Velho (1957), A Geração do } \\
\text { Deserto. }\end{array}$ & 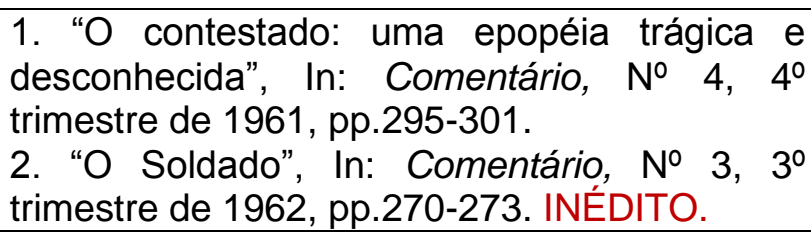 \\
\hline $\begin{array}{l}\text { SCHIFNAGEL, } \\
\text { Isaac. }\end{array}$ & Advogado e jornalista. & $\begin{array}{l}\text { 1. "Prescreverão os crimes nazistas?", In: } \\
\text { Comentário, Ano VI, n. 3, 1965, pp. 207-215. }\end{array}$ \\
\hline $\begin{array}{l}\text { SCHNEIDER, } \\
\text { Eliezer. }\end{array}$ & $\begin{array}{l}\text { Professor de Psicologia da Universidade do Brasil. Escreveu } \\
\text { muito artigos para o "Boletim do Instituto de Psicologia". } \\
\text { Formou-se pela lowa State University. }\end{array}$ & $\begin{array}{l}\text { 1. "Autoritários, Anti-semitas e liberticidas", In: } \\
\text { Comentário, № 4, 40 trimestre de 1962, } \\
\text { pp.326-330. }\end{array}$ \\
\hline $\begin{array}{l}\text { SCOLNICOV, } \\
\text { Samuel. }\end{array}$ & $\begin{array}{l}\text { Estudou na Universidade de Jerusalém, quando traduziu do } \\
\text { hebraico para o português uma antologia de poemas } \\
\text { israelenses publicadas em Comentário. }\end{array}$ & $\begin{array}{l}\text { 1. "Poemas Israelenses", trad. Samuel } \\
\text { Scolnicov, In: Comentário, № } 4 \text {, } 4^{\circ} \text { trimestre } \\
\text { de } 1960 \text {, pp. } 60-67 \text {. } \\
\text { 2. Hayim Guri, “Jazem aqui nossos corpos", } \\
\text { trad. Samuel Scolnicov, In: Comentário, № } 4 \text {, } \\
\text { 4 trimestre, } 1961, \text { p. } 356 \text {. }\end{array}$ \\
\hline SILVA, Mário da & $\begin{array}{l}\text { Morou por muitos anos na Itália onde atuou como jornalista, } \\
\text { desenvolvendo também atividade literária. Quando voltou para o } \\
\text { Brasil retomou sua atividade de tradutor especialista de peças } \\
\text { teatrais. }\end{array}$ & $\begin{array}{l}\text { 1.“Nazismo e Antissemitismo", In: Comentário, } \\
\text { № } 2,2^{\circ} \text { trimestre de } 1960 \text {, pp. } 32-38 \text {. }\end{array}$ \\
\hline $\begin{array}{l}\text { SIMONSEN, Mário } \\
\text { Henrique. }\end{array}$ & Economista. & $\begin{array}{l}\text { 1. "O PAEG e a racionalidade em política } \\
\text { econômica", In: Comentário, Ano VII, n. } 3 \text {, }\end{array}$ \\
\hline
\end{tabular}




\begin{tabular}{|c|c|c|}
\hline & & 1966, pp. 222-228. \\
\hline $\begin{array}{l}\text { TEIXEIRA, } \\
\text { Anísio }{ }^{403} \text {. } \\
\text { 1900/1971 } \\
\text { [Caitité (BA)/ Rio } \\
\text { de Janeiro (RJ)] }\end{array}$ & $\begin{array}{l}\text { Formação em Ciências Jurídicas e Sociais no Rio de Janeiro. } \\
\text { Diretor-geral de Instrução do governo da Bahia (1924-28). } \\
\text { Estudou na Universidade de Columbia (EUA). Sofreu influência } \\
\text { das ideias pedagógicas de John Dewey. Defensor da Escola } \\
\text { Nova (pública gratuita, laica e obrigatória). Acusado de } \\
\text { envolvimento no levante comunista de 1935. Enfrentou } \\
\text { oposição de expoentes do pensamento católico conservador. } \\
\text { Foi conselheiro de educação superior da UNESCO (1946), } \\
\text { dirigente da CAPES de 1952-1964 e reitor da UnB de 1963- } \\
1964 \text {. Titular da cadeira de administração escolar e educação } \\
\text { comparada da Faculdade Nacional de Filosofia. Foi nomeado } \\
\text { membro do Conselho Federal de Educação em 1962, tornando- } \\
\text { se presidente da Comissão Nacional do Ensino Primário em } \\
1963 \text {. Foi professor residente das Universidades de Columbia e } \\
\text { da Califórnia (1964-1966). Em 1966 foi consultor educacional da } \\
\text { Fundação Getúlio Vargas (FGV). Influente educador no Brasil } \\
\text { participou de diversos projetos e eventos internacionais sobre o } \\
\text { tema. Palestrou em países asiáticos e americanos. Elaborou } \\
\text { programas de intercâmbio universitário e reformou o programa } \\
\text { educacional da Organização dos Estados Americanos (OEA). } \\
\text { Escreveu em A Manhã (jornal oficioso da ANL). Autor de artigos } \\
\text { em revistas especializadas e obras, entre elas Aspectos } \\
\text { americanos da educação (1928), Educação progressiva (2ª ed., } \\
1934 \text { ), Educação para a democracia (1936), A educação e a } \\
\text { crise brasileira (1956) e Educação não é privilégio (1957). }\end{array}$ & $\begin{array}{l}\text { 1. "A Nova Lei de Diretrizes e Bases: um } \\
\text { anacronismo educacional", In: Comentário, } \\
\text { janeiro-fevereiro-março, 1960, n 1, ano I, pp. } \\
\text { 16-20. (educação) }\end{array}$ \\
\hline $\begin{array}{ll}\text { VAL, } & \text { Waldir } \\
\text { Ribeiro do. } & \end{array}$ & $\begin{array}{l}\text { Poeta. Co-diretor do Anuário da Literatura Brasileira. } \\
\text { Organizador da Obra Poética Completa de Raimundo Correia. } \\
\text { Colaborou em vários suplementos literários no Rio de Janeiro. } \\
\text { Livros: Orvalho (1949), Cântaros Vazios (1952). Ensaio: }\end{array}$ & $\begin{array}{l}\text { 1. "O Rio de Janeiro de Machado de Assis", In: } \\
\text { Comentário, 1961, n. 1, ano II, pp. 29-36. }\end{array}$ \\
\hline
\end{tabular}

\footnotetext{
${ }^{403}$ As informações a respeito de Anísio Teixeira foram retiradas do site do CPDOC www.cpdoc.fgv.br, em verbete sobre Anisio Teixeira no DHBB, acessado em 10/02/2001.
} 


\begin{tabular}{|c|c|c|}
\hline & Raimundo Correia, estudante (1955). & \\
\hline $\begin{array}{l}\text { VERISSIMO, } \\
\text { Erico. }\end{array}$ & $\begin{array}{l}\text { Escritor. Escreveu: Gato Prêto em Campo de neve; A Volta do } \\
\text { Gato Prêto e México (livros de viagem). }\end{array}$ & $\begin{array}{l}\text { 1. "Estampas da Holanda", In: Comentário, } \\
\text { 1960, n. 4, ano I, pp. 30-39. }\end{array}$ \\
\hline WALD, Arnold ${ }^{404}$. & $\begin{array}{l}\text { Docente livre da Faculdade Nacional de Direito e Catedrático da } \\
\text { Faculdade de Direito do Rio de Janeiro. Foi nomeado } \\
\text { Procurador-geral do Estado da Guanabara em dezembro de } \\
\text { 1965. Escreveu: A Responsabilidade Civil (1951); Evolução do } \\
\text { Direito (1951); A Cláusula de Escala Móvel (1956); Do mandado } \\
\text { de segurança (1958); a teoria das dívidas de valor (1958); O } \\
\text { desquite (1959). }\end{array}$ & $\begin{array}{l}\text { 1. "Os Direitos dos Naturalizados no Brasil", } \\
\text { Comentário, } 1960, \text { n. } 2 \text {, ano I, pp. 39-42. } \\
\text { 2. "O Direoto do Desenvolvimento", In: } \\
\text { Comentário, ANO VIII, n. 3, 1967, pp. 265- } \\
278 .\end{array}$ \\
\hline
\end{tabular}

\footnotetext{
${ }^{404}$ Cf. informações sobre o autor também em Alfred Hirschberg, "Brasil", Foreign Coutries: Latin America, American Jewish Year Book (AJYB), Vol. 67,
} 1966, p. 305. In: http://www.ajcarchives.org/AJC DATA/Files/1966 8 LatAmerica.pdf, acesso em 15/04/2011. 


\begin{tabular}{|c|c|c|}
\hline \multicolumn{3}{|c|}{ Comentário: Autores Internacionais } \\
\hline $\begin{array}{l}\text { Nome, Data e Lugar } \\
\text { de Nascimento }\end{array}$ & Profissão/Carreira/Obra/Observações & Artigos em Comentário \\
\hline BAECK, Leo. & $\begin{array}{l}\text { Foi rabino-chefe de Berlim, líder dos judeus alemães durante o } \\
\text { nazismo, professor do Hebrew Union College. Autoridade em } \\
\text { assuntos judaicos. Sobrevivente do nazismo. Esteve no } \\
\text { campo de concentração de Theresienstadt. Escreveu Os } \\
\text { Fariseus e outros ensaios; A essência do judaísmo. }\end{array}$ & $\begin{array}{l}\text { 1."Moisés Maimônides: o homem e a obra", } \\
\text { In: Comentário, 1961, n 3, ano II, pp. 244- } \\
\text { 253. }\end{array}$ \\
\hline BARON, Salo W. & $\begin{array}{l}\text { Historiador. Professor de História Judaica na Universidade de } \\
\text { Columbia. Ocupou o cargo de Presidente da Conferência de } \\
\text { Estudos Sociais Judaicos nos Estados Unidos. }\end{array}$ & $\begin{array}{l}\text { 1."Novas Tônicas na História Judaica”, In: } \\
\text { Comentário, 1965, n 2, ano VI, pp. 115-125. }\end{array}$ \\
\hline BORGER, Hans. & Pesquisador da História Judaica. & $\begin{array}{l}\text { 1."Antecedentes da Revolta dos Macabeus", } \\
\text { In: Comentário, Ano IV, n. 1, 1963, pp. 71- } \\
\text { 79. }\end{array}$ \\
\hline $\begin{array}{l}\text { BOROWITZ, } \\
\text { Eugene B. }\end{array}$ & $\begin{array}{l}\text { Professor do Hebrew Union College-Jewish Institute of } \\
\text { Religion dos Estados Unidos. }\end{array}$ & $\begin{array}{l}\text { 1. "Teologia Judaica: Milton Steinber e } \\
\text { depois", In: Comentário, Ano VIII, n. 2, } \\
\text { 1967, pp. 152-158. }\end{array}$ \\
\hline $\begin{array}{l}\text { BOROWSKI, } \\
\text { Tadeusz. } \\
\text { /1951 } \\
\text { (Polônia/ Varsóvia - } \\
\text { Polônia) }\end{array}$ & $\begin{array}{l}\text { Poeta ficcionista. O escritor polonês passou diversos anos } \\
\text { como preso político em campos de concentração nazistas. } \\
\text { Publicou em seguida diversos contos extremamente realistas } \\
\text { baseados na sua experiência concentracionária. Foi um } \\
\text { grande entusiasta do regime comunista no pós-guerra. } \\
\text { Suicidou-se em } 1951 \text { em Varsóvia. Escreveu Adeus, Maria. }\end{array}$ & $\begin{array}{l}\text { 1. "Á Câmara de Gás, por aqui", In: } \\
\text { Comentário, Ano IV, n. 1, 1963, pp. 57-66. }\end{array}$ \\
\hline CASSIN, René. & $\begin{array}{l}\text { "Um dos promotores da ideia de uma Declaração Universal } \\
\text { dos Direitos Humanos". Foi professor das Escolas de Direito } \\
\text { de Paris e de Lille, vice-presidente do Conselho de Estado da } \\
\text { França e membro das delegações francesas à ONU e à } \\
\text { UNESCO. Ainda foi presidente da Associação francesa dos } \\
\text { Ex-Combatentes e da Aliança Israelita Universal. }\end{array}$ & $\begin{array}{l}\text { 1."Como lograr um mundo melhor", In: } \\
\text { Comentário, } 1961, \mathrm{n} 4 \text {, ano II, pp. 358-363. }\end{array}$ \\
\hline COHEN, Samuel S. & $\begin{array}{l}\text { Educador de origem russa radicado nos Estados Unidos } \\
\text { desde 1904. Professor de teologia judaica no Jewish Institute } \\
\text { of Religion da Universidade de Cincinatti. Escreveu Authority } \\
\text { in Judaism, Saadia Gaom, Judaism: a way of life. }\end{array}$ & $\begin{array}{l}\text { 1. "Liberdade e Determinismo na concepção } \\
\text { judaica", In: Comentário, 1960, n. 4, ano I, } \\
\text { pp. 40-47. }\end{array}$ \\
\hline COOPER, Elias. & Foi Professor do Departamento de História do City College de & 1. "A Política Nazista no Oriente Médio", In: \\
\hline
\end{tabular}




\begin{tabular}{|c|c|c|}
\hline & Nova lorque. & Comentário, 1965, n 1, ano VI, pp. 14-28. \\
\hline $\begin{array}{l}\text { DESSER, Joan. } \\
\text { (Estados Unidos/) }\end{array}$ & $\begin{array}{l}\text { Visitou Israel em viagem de estudo sobre o fenômeno } \\
\text { psicológico da vida nas colônias agrícolas coletivas - o } \\
\text { "kibutz". }\end{array}$ & $\begin{array}{l}\text { 1. "A Educação Infantil no Jibitz de Israel", } \\
\text { In: Comentário, ANO III, n. 4, 1962, pp. } \\
\text { 350-354. }\end{array}$ \\
\hline $\begin{array}{l}\text { DRAPER, } \\
\text { Theodore. }\end{array}$ & $\begin{array}{l}\text { Colaborador da revista Encounter. Foi Professor visitante de } \\
\text { ciência Política na Universidade de Yale, nos EUA, em } 1968 .\end{array}$ & $\begin{array}{l}\text { 1. "Além de Berlim - Existirá um novo } \\
\text { 'equilíbrio de fôrças", In: Comentário, ANO } \\
\text { V, n. 1, 1964, pp.7-16. } \\
\text { 1. "Israel e a Política Mundial", In: } \\
\text { Comentário, ANO VIII, n. 3, 1967, pp. 209- } \\
257 \text {. }\end{array}$ \\
\hline EPSTEIN, Jason. & $\begin{array}{l}\text { Editor norte-americano que escrevia regularmente na revista } \\
\text { Commentary. Publicou o artigo-denúncia na revista New York } \\
\text { Review of Books, "The CIA and the intellectuals" em } \\
\text { 20/04/1967. }\end{array}$ & 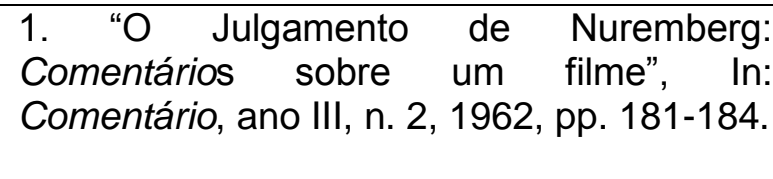 \\
\hline $\begin{array}{l}\text { FACKENHEIM, } \\
\text { Emil. }\end{array}$ & $\begin{array}{l}\text { Teólogo. Foi Professor de Filosofia da Universidade de } \\
\text { Toronto. }\end{array}$ & $\begin{array}{l}\text { 1. "Judaísmo e Sentido da Vida", In: } \\
\text { Comentário, na Ano VI, n. 3, 1965, pp. 247- } \\
\text { 256. }\end{array}$ \\
\hline $\begin{array}{l}\text { FAST, Howard } \\
1914 / 2003 \\
\text { (cidade de Nova } \\
\text { lorque/ Greenwich- } \\
\text { Connecticut) }\end{array}$ & $\begin{array}{l}\text { Escritor norte-americano reconhecido internacionalmente. Seu } \\
\text { nome consta nos arquivos do FBI. Teve seus livros } \\
\text { censurados pelo Departamento de Estado norte-americano } \\
\text { (década de 1950, macarthismo) }{ }^{405} \text {. Rompeu com o Partido } \\
\text { Comunista no final da década de } 1950 \text {. Escreveu Os nossos } \\
\text { gloriosos irmãos e O Deus Nu. (traduzidos para o português), } \\
\text { entre outros. }\end{array}$ & $\begin{array}{l}\text { 1.“A provação de Boris Pasternak", In: } \\
\text { Comentário, 1960, n 1, ano I, pp. 9-15. }\end{array}$ \\
\hline $\begin{array}{l}\text { FILKENSTEIN, } \\
\text { Louis. } \\
1895 / \\
\text { (Cincinnati/) }\end{array}$ & $\begin{array}{l}\text { Foi presidente do Seminário Teológico Judaico da América. } \\
\text { Estudou em Nova lorque no colégio e na Universidade de } \\
\text { Colúmbia. Foi ordenado em } 1919 \text { no Seminário Teológico, } \\
\text { onde fundou em } 1939 \text { o Instituto de Estudos Religiosos com a } \\
\text { colaboração de estudioso católicos, judeus e protestantes. } \\
\text { Escreveu Jewish Self-government in the Middle Ages (1924); } \\
\text { Maimonides and the Tannaitic Midrashim (1925); Akiba, } \\
\text { Scholar, Saint and Martyr (1936), /the Pharisees (1938) e The } \\
\text { Beliefs and Practices of Judaism (1941). }\end{array}$ & $\begin{array}{l}\text { 1. "A Inquietação do Homem Moderno e seu } \\
\text { remédio", In: Comentário, 1962, n 3, ano III, } \\
\text { pp. 235-244. }\end{array}$ \\
\hline
\end{tabular}

$\overline{405}$ F. S. Saunders, Quem pagou a conta? A CIA na Guerra Fria da Cultura. Rio de Janeiro/ São Paulo: Editora Reoord, 2008, pp. 214-216 


\begin{tabular}{|c|c|c|}
\hline $\begin{array}{l}\text { FRANKEL, } \\
\text { Theodore. }\end{array}$ & $\begin{array}{l}\text { Professor. Lecionou no Programa de Ultramar da Universidade } \\
\text { norte-americana de Maryland. Foi colaborador de } \\
\text { Commentary, Yale Review e Midstream (revista sionista). }\end{array}$ & $\begin{array}{l}\text { 1. "A ficção alemã e a busca da purificação", } \\
\text { In: Comentário, 1961, n 2, ano II, pp. 139- } \\
\text { 143. } \\
\text { 2. "Arte, Política - Liberdade Soviética", In: } \\
\text { Comentário, 1967, n. 1, ano VIII, pp. 5-16. }\end{array}$ \\
\hline FREIBERG, Selma. & $\begin{array}{l}\text { Foi membro da School os Social Work, da Universidade de } \\
\text { Tulane. Escreveu The Magic Years. }\end{array}$ & $\begin{array}{l}\text { 1. "A Ciência do Contrôle Mental", In: } \\
\text { Comentário, 1963, n. 1, ano IV, pp. 91-102. }\end{array}$ \\
\hline $\begin{array}{l}\text { FRIEDMAN, } \\
\text { Maurice. }\end{array}$ & $\begin{array}{l}\text { Professor de Filosofia no Sarah Lawrence College. Ensinou } \\
\text { filosofia religiosa como convidado no Hebrew Union College, } \\
\text { em Cincinnati. Escreveu Martin Buber: The Life of Dialogue }\end{array}$ & $\begin{array}{l}\text { 1. "Três Pensadores Judeus } \\
\text { Contemporâneos - Kaplan - Heschel - } \\
\text { Buber", In: Comentário, 1961, n 4, ano II, } \\
\text { pp. 318-330. }\end{array}$ \\
\hline FYVEL, T. R. & Colaborador da revista sionista Midstream. & $\begin{array}{l}\text { "A vida tormentosa de Ilya Ehrenburg", In: } \\
\text { Comentário, Ano III, n. 4, pp. 295-308. }\end{array}$ \\
\hline GILBERT, Arthur. & $\begin{array}{l}\text { Rabino. Foi diretor de atividades Inter-religiosas da Anti } \\
\text { defamation league dos Estados Unidos. Gilbert atuou junto à } \\
\text { National Conference of Christians and Jews, organização que } \\
\text { trabalhava no sentido de aproximar judeus e cristãos. }\end{array}$ & $\begin{array}{l}\text { 1. "O Concílio Ecumênico e os Judeus", In: } \\
\text { Comentário, 1962, n 3, ano III, pp. 199-209. }\end{array}$ \\
\hline $\begin{array}{l}\text { GRADENWITZ, } \\
\text { Peter. }\end{array}$ & Musicólogo israelense. Pesquisador de música judaica. & $\begin{array}{l}\text { 1. “A Ópera 'Moisés e Aarão' - Um gênio } \\
\text { musical como filósofo religioso", In: } \\
\text { Comentário, } 1961, \mathrm{n} 1 \text {, ano II, pp. } 68-72 \text {. }\end{array}$ \\
\hline GRANOT, Abraham. & $\begin{array}{l}\text { Foi Professor da Universidade Hebraica e diretor do Keren } \\
\text { Kayemet Leisrael (Fundo Agrário de Israel). Escreveu O } \\
\text { Regime de Terras em Israel, A Terra e o Lavrador. }\end{array}$ & $\begin{array}{l}\text { 1. "Política Agrária para Israel", In: } \\
\text { Comentário, Ano III, no 1, 1962, pp. 28-34. }\end{array}$ \\
\hline $\begin{array}{l}\text { GROSSMAN, Meir. } \\
\text { (Israel/) }\end{array}$ & $\begin{array}{l}\text { Especialista em problemas do Oriente Médio. Escrevia } \\
\text { regularmente em publicações européias, americanas e } \\
\text { israelenses. }\end{array}$ & $\begin{array}{l}\text { 1. "Nasser tem problemas", In: Comentário, } \\
\text { Ano III, № 2, 1962, pp. 177-180. }\end{array}$ \\
\hline $\begin{array}{l}\text { HALBERSTAM, } \\
\text { David. }\end{array}$ & $\begin{array}{l}\text { Jornalista ganhador do Prêmio Pullitzer por sua cobertura } \\
\text { sobre o Vietnam para o New York Times. }\end{array}$ & $\begin{array}{l}\text { 1. "Fazendo a notícia no Vietnam", In: } \\
\text { Comentário, Ano VI, n. 4, 1965, pp. 293- } \\
\text { 300. }\end{array}$ \\
\hline $\begin{array}{l}\text { HALKIN, Simon. } \\
\text { (Rússia/) }\end{array}$ & $\begin{array}{l}\text { Poeta hebraico e estudioso dessa literatura. Professor-adjunto } \\
\text { da cátedra de Literatura Hebraica na Universidade Hebraica } \\
\text { de Jerusalém. Estudou na Universidade de Columbia e na de } \\
\text { Nova Iorque. Dirigiu a cadeira no Instituto Judeu de Religião } \\
\text { nos Estados Unidos. Traduziu para o hebraico comédias de } \\
\text { Shakespeare, poemas de Shelley, de Walt Whitman e de }\end{array}$ & $\begin{array}{l}\text { 1. "A Literatura Hebraica Moderna", In: } \\
\text { Comentário, Ano I, no 2, 1960, pp. 43-48. }\end{array}$ \\
\hline
\end{tabular}




\begin{tabular}{|c|c|c|}
\hline & $\begin{array}{l}\text { Maurice Maeterlinck; publicou romances em hebraico e } \\
\text { monografias sobre literatura européia e norte-americana. }\end{array}$ & \\
\hline $\begin{array}{l}\text { HENRIQUEZ, Raul } \\
\text { Silva. }\end{array}$ & Cardeal-Arcebispo de Santiago do Chile. & $\begin{array}{l}\text { 1. "Direitos Humanos no Antigo } \\
\text { Testamento", In: Comentário, Ano VII, n. 1, } \\
\text { 1966, pp. 33-38. }\end{array}$ \\
\hline HERBERG, Will. & $\begin{array}{l}\text { Professor de Filosofia na Duke University Escreveu Católico- } \\
\text { Protestante-Judeu. }\end{array}$ & $\begin{array}{l}\text { 1. “O 'Pluralismo Religioso' nos Estados } \\
\text { Unidos", In: Comentário, 1961, n. 1, ano I, } \\
\text { pp. 21-28. }\end{array}$ \\
\hline $\begin{array}{l}\text { HESCHEL, } \\
\text { Abraham Joshua } \\
\text { (Alemanha/) }\end{array}$ & $\begin{array}{l}\text { Professor de Filosofia Judaica no Seminário Teológico Judeu } \\
\text { de Nova lorque, na Universidade de Columbia. Considerado } \\
\text { pelo sociólogo Joseph H. Lockstein como um renovador do } \\
\text { hassidismo. Escreveu A Terra é do Senhor; O Homem não } \\
\text { está só; } \text { A Filosofia do Judaísmo, Sábado, entre outros. }\end{array}$ & $\begin{array}{l}\text { 1. "A Crise da Religião em nosso tempo", } \\
\text { Comentário, 1960, n. 2, ano I, pp. 23-31. } \\
\text { 2. "A Imagem Sagrada do Homem", In: } \\
\text { Comentário, n. 2, ano III, 1962, pp. 144-150. }\end{array}$ \\
\hline JOUHY, Ernst & Psicólogo. & $\begin{array}{l}\text { 1. "A Juventude Alemã e a História Alemã", } \\
\text { In: Comentário, 1960, n. 4, ano I, pp. 14-20. }\end{array}$ \\
\hline $\begin{array}{l}\text { KAUFMAN, } \\
\text { Jehezkel. }\end{array}$ & $\begin{array}{l}\text { Professor da Universidade Hebraica de Jerusalém. Detentor } \\
\text { do Prêmio Bialik da municipalidade de Tel-Aviv. Estudou na } \\
\text { Academia de Ciências Judaicas de Leningrado e na } \\
\text { Universidade de Berna. Estudioso da filosofia Judaica. } \\
\text { Escreveu vários artigos a respeito. }\end{array}$ & $\begin{array}{l}\text { 1. "A Fé de Israel - gênese e natureza", In: } \\
\text { Comentário, 1962, n 4, ano III, pp. 317-325. }\end{array}$ \\
\hline KECHET, Yoel. & Jornalista israelense. Escrevia para o jornal Davar de Telaviv. & $\begin{array}{l}\text { 1. "A Sorte dos Refugiados Árabes", In: } \\
\text { Comentário, 1961, n. 1, ano III, pp. 18-22. }\end{array}$ \\
\hline KOHN, Leo. & $\begin{array}{l}\text { Professor de Relações Internacionais na Universidade } \\
\text { Hebraica de Jerusalém. Entre 1934-1948 foi secretário político } \\
\text { da Agência Judaica. Foi, a partir de } 1948 \text {, Conselheiro Político } \\
\text { do Ministério das Relações Exteriores de Israel. O artigo } 1 \text { foi } \\
\text { reproduzido por Comentário diretamente da revista } \\
\text { International Affairs. }\end{array}$ & $\begin{array}{l}\text { 1. "Relações Internacionais de Israel", In: } \\
\text { Comentário, } 1961 \text {, n. 2, ano II, pp. 110-118. }\end{array}$ \\
\hline KOREY, William. & $\begin{array}{l}\text { O autor era diretor do Escritório do Conselho Internacional da } \\
\text { B'nai B'rith de Nova lorque. }\end{array}$ & $\begin{array}{l}\text { 1. "A Lei Soviética e os Judeus", In: } \\
\text { Comentário, Ano VII, n. 3, p. } 221 .\end{array}$ \\
\hline $\begin{array}{ll}\text { LAPIDE, } & \text { Phinn } \\
\text { (Pinchas) E. } & \\
\text { (Canadá/ ) } & \end{array}$ & $\begin{array}{l}\text { Escritor e diplomata. Jornalista. Foi alto funcionário do } \\
\text { Ministério das Relações Exteriores de Israel. Serviu no Rio de } \\
\text { Janeiro como adido cultural de Israel. Escreveu The Prophet of } \\
\text { San Nicandro: A Modern Adventure in the Discovery of Faith e } \\
\text { O Canhão e a foice. }\end{array}$ & $\begin{array}{l}\text { 1. "O Canhão e a Foice", trecho, In: } \\
\text { Comentário, } 1960, \text { n 1, ano I, Seção "No } \\
\text { prelo", pp. } 67-72 \text {. } \\
\text { 2. "Uma história de duas aldeias", resumo } \\
\text { de The Profet of San Nicandro escrito }\end{array}$ \\
\hline
\end{tabular}




\begin{tabular}{|c|c|c|}
\hline & & $\begin{array}{l}\text { exclusivamente para Comentário, 1963, n. } \\
\text { 1, Ano IV, pp. 7-19. } \\
\text { 3. "Paulus Peregrinus", In: Comentário, } \\
\text { 1964, n. 2, ANO V, pp. 115-117. }\end{array}$ \\
\hline LEHRMAN, Hal. & $\begin{array}{l}\text { Conferencista. Colaborador das revistas Midstream (revista } \\
\text { sionista) e Commentary, entre outras. }\end{array}$ & $\begin{array}{l}\text { 1.“Uma Língua volta à vida", In: Comentário, } \\
1961, \text { n. 2, ano II, pp. 150-158. }\end{array}$ \\
\hline LESLAU, Wolf. & $\begin{array}{l}\text { Prof. Especialista no idioma etíope. Lecionou na Sorbonne e } \\
\text { na Escola Nacional de Línguas Orientais de Paris. }\end{array}$ & $\begin{array}{l}\text { 1."Os Judeus Pretos da Etiópia", In: } \\
\text { Comentário, } 1961, \mathrm{n} 2 \text {, ano II, pp.144-149. }\end{array}$ \\
\hline LEVIN, Shaul. & $\begin{array}{l}\text { Foi Ministro Conselheiro para Assuntos Culturais de Israel na } \\
\text { América Latina, membro do Conselho de Cultura de Israel e } \\
\text { Diretor-geral de Educação e Cultura de Telaviv. Foi } \\
\text { condecorado por diversos governos, tendo recebido a "Legião } \\
\text { de Honra" da França. }\end{array}$ & $\begin{array}{l}\text { 1.“Israel e o Judaísmo", In: Comentário, } \\
\text { 1964, n 2, ano V, pp.177-179. }\end{array}$ \\
\hline LEWIS, W. A. & Economista. Foi diretor da Universidade das Índias Orientais. & $\begin{array}{l}\text { 1. "Problemas dos novos Estados", In: } \\
\text { Comentário, } 1961 \text {, n. } 1 \text {, ano II, pp. 52-58. }\end{array}$ \\
\hline $\begin{array}{l}\text { LEWY, Immanuel. } \\
\text { (Berlim - Alemanha/ } \\
\text { ) }\end{array}$ & $\begin{array}{l}\text { Ensaísta. Nascido em Berlim, Immanuel Lewy transferiu-se } \\
\text { para os estados Unidos em 1945. Formado pelas } \\
\text { Universidades de Berlim, Leipzig e por uma academia } \\
\text { rabínica. Escreveu The birth of the Bible - a new approach } \\
\text { (1950). }\end{array}$ & $\begin{array}{l}\text { 1. "A Arqueologia e a verdade histórica da } \\
\text { Bíblia", In: Comentário, ano II, n. } 3,1961 \text {, } \\
\text { pp. 231-240. }\end{array}$ \\
\hline $\begin{array}{l}\text { LOCKSTEIN, } \\
\text { Joseph H. }\end{array}$ & $\begin{array}{l}\text { Professor de sociologia da Universidade leshiva de Nova } \\
\text { lorque. }\end{array}$ & $\begin{array}{l}\text { 1. "O Existencialismo Judaico", In: } \\
\text { Comentário, ano II, n. 2, 1961, pp. 166-172. }\end{array}$ \\
\hline $\begin{array}{l}\text { LOWENTHAL, } \\
\text { Richard. }\end{array}$ & $\begin{array}{l}\text { Escritor e jornalista. Morava em Londres e colaborava com a } \\
\text { revista Commentary de Nova lorque, onde publicou em } 1959 \\
\text { estudo sobre "O comunismo flexível de Krushev". Trabalhou } \\
\text { no Centro de Pesquisas Russas da Harvard University. }\end{array}$ & $\begin{array}{l}\text { 1. "O novo exame do totalitarismo", In: } \\
\text { Comentário, ano II, n. 3, 1961, pp. 199-208. }\end{array}$ \\
\hline $\begin{array}{l}\text { MARIENSTRAS, } \\
\text { Richard. }\end{array}$ & Jornalista francês. & $\begin{array}{l}\text { 1. "Israel não é negociável", In: Comentário, } \\
\text { Ano IX, 1968, pp. 117-123. }\end{array}$ \\
\hline $\begin{array}{l}\text { NEWMAN, William } \\
\text { J. }\end{array}$ & $\begin{array}{l}\text { Professor da Universidade de Boston. Especialista em } \\
\text { problemas africanos. }\end{array}$ & 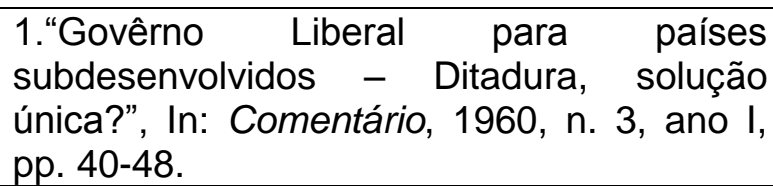 \\
\hline PALLY, Paul de. & $\begin{array}{l}\text { Jornalista canadense. Estudou em Israel o problema da } \\
\text { integração dos imigrantes judeus provenientes dos países }\end{array}$ & $\begin{array}{l}\text { 1."Os Refugiados dos países árabes", In: } \\
\text { Comentário, 1962, n. 1, ano III, pp. 7-17. }\end{array}$ \\
\hline
\end{tabular}




\begin{tabular}{|c|c|c|}
\hline & árabes. & $\begin{array}{l}\text { 2.“Livros na Terra dos Livros", Comentário, } \\
\text { 1965, n. 1, ano IV, pp. } 70-75 \text {. }\end{array}$ \\
\hline $\begin{array}{l}\text { PETUCHOWSKI, } \\
\text { Jacob J. }\end{array}$ & $\begin{array}{l}\text { Ensaista de temas religiosos. Foi professor do Hebrew Union } \\
\text { College de Cincinnati - Seminário rabínico do ramo reformista } \\
\text { do judaísmo. }\end{array}$ & $\begin{array}{l}\text { 1. "Paulo e a teologia judaica", In: } \\
\text { Comentário, Ano VI, no 3, 1965, pp. 268- } \\
\text { 274. }\end{array}$ \\
\hline POLIAKOV, Léon. & Historiador. & $\begin{array}{l}\text { 1. "A Indústria da Morte", In: Comentário, } \\
\text { Ano I, № } 3,1960, \text { pp. } 16-24 \text {. }\end{array}$ \\
\hline REINES, Ch. W. & $\begin{array}{l}\text { Rabino norte-americano. Ensaísta e investigador da filosofia } \\
\text { judaica. O artigo "Religião e Trabalho" foi publicado antes na } \\
\text { revista Judaism de Nova lorque. }\end{array}$ & $\begin{array}{l}\text { 1. "Religião e Trabalho", In: Comentário, } \\
\text { Ano I, no 3, 1960, pp. 33-39. }\end{array}$ \\
\hline $\begin{array}{l}\text { RODITI, Edouard. } \\
\text { (Paris/) }\end{array}$ & $\begin{array}{l}\text { Trabalhou como intérprete no processo dos criminosos } \\
\text { nazistas de guerra em Nuremberg e na Conferência de S. } \\
\text { Francisco. }\end{array}$ & $\begin{array}{l}\text { 1. "Uma Família Sefaradita", In: Comentário, } \\
\text { Ano II, no } 4,1961 \text {, pp. 348-355. }\end{array}$ \\
\hline $\begin{array}{l}\text { ROTH, Cecil }{ }^{406} \\
1899 / 1970 \\
\text { (Londres/Jerusalém) }\end{array}$ & $\begin{array}{l}\text { Historiador. Especialista em Arte Judaica. Professor. } \\
\text { Acadêmico. Estudou na Universidade de Oxford onde se } \\
\text { doutorou em 1924, foi professor assistente em Estudos } \\
\text { Judaicos em Oxford entre } 1939 \text { e } 1964 \text {. Depois foi professor } \\
\text { visitante na Universidade Bar-llan, em Israel (1964-1965), e } \\
\text { na City University of New York (1966-1969). Foi editor da } \\
\text { Encyclopaedia Judaica de } 1965 \text { até a sua morte. Roth } \\
\text { escreveu uma carta de protesto ao London Times contra a } \\
\text { declaração de boicote aos estabelecimentos judaicos de Hitler. } \\
\text { Escreveu numerosos artigos e livros a respeito da cultura } \\
\text { judaica, especificamente para que os alemães e o mundo } \\
\text { pudessem valorizá-la, numa tentativa de minimizar os maus } \\
\text { tratos sofridos pelos judeus. Publicou mais de } 600 \text { artigos e } \\
\text { livros traduzidos em diversas línguas, ente eles Histories of the } \\
\text { Jews in England (1941) and Italy (1946), A History of the } \\
\text { Marranos (3d ed. 1966), The Jews in the Renaissance (1959), } \\
\text { Jewish Art (1961), and The Dead Sea Scrolls (1965); The } \\
\text { House of Nasi, A Short History of the Jewish People, The } \\
\text { Jewish Contribution to Civilization e The Standard Jewish }\end{array}$ & $\begin{array}{l}\text { 1. "Manuscritos do Mar Morto - Chaves } \\
\text { para uma Época", In: Comentário, revista } \\
\text { trimestral, Ano I, no. 1, 1960, pp. 42-49. } \\
\text { 2. "Simão Bar Giora, Herói Judeu", In: } \\
\text { Comentário, Ano I, no 3, 1960, pp. 25-32. } \\
\text { 3. "Ainda os Manuscritos do Mar Morto", In: } \\
\text { Comentário, revista trimestral, Ano V, no. 3, } \\
\text { 1964, pp. 242-250. } \\
\text { 4. "Cabeças de Aves e Imagens gravadas", } \\
\text { In: Comentário, Ano X, №. 2, 1969, pp. 147- } \\
\text { 152. }\end{array}$ \\
\hline
\end{tabular}

${ }^{406}$ As informações a respeito de Cecil Roth foram retiradas do site da Oxford Chabad Society http://www.oxfordchabad.org/templates/articlecco_cdo/AID/457404, acesso em 07/10/2009. 


\begin{tabular}{|c|c|c|}
\hline & Encyclopedia. & \\
\hline $\begin{array}{l}\text { SCHECHTMAN, } \\
\text { Joseph B. }\end{array}$ & $\begin{array}{l}\text { Colaborador de várias revistas americanas e européias, entre } \\
\text { elas, a revista Midsream. }\end{array}$ & $\begin{array}{l}\text { 1. "Uma visita a Babiy-yar", In: Comentário, } \\
\text { 1962, n. 1, ano III, pp. 42-51. } \\
\text { 1. "Índia e Israel", In: Comentário, Ano VIII, } \\
\text { no. } 2 \text { 1967, pp. 127-139. }\end{array}$ \\
\hline $\begin{array}{l}\text { SCHOLEM, } \\
\text { Gershom. } \\
\text { (Alemanha/) }\end{array}$ & $\begin{array}{l}\text { Historiador. Foi Professor de Misticismo Judaico da } \\
\text { Universidade Hebraica de Jerusalém. Escreveu: Principais } \\
\text { Tendências do Misticismo Judaico e Da Cabala e seu } \\
\text { Simbolismo. }\end{array}$ & $\begin{array}{l}\text { 1. "Autoridade Religiosa e Misticismo", In: } \\
\text { Comentário, Ano VI, n. 1,1965, pp. 42-54. } \\
\text { 2. "Judeus e Alemães", In: Comentário, Ano } \\
\text { VIII, n. 1, 1967, pp. 17-28. }\end{array}$ \\
\hline SCHULMAN, Elias. & $\begin{array}{l}\text { Bibliotecário do Comitê de Educação Judaica de Nova lorque } \\
\text { e autor de Jewish Education in the Soviet Union. }\end{array}$ & $\begin{array}{l}\text { 1. "Scholem Aleichem", In: Comentário, Ano } \\
\text { VIII, n, 1, 1967, pp. 78-82. }\end{array}$ \\
\hline SHERMAN, A. V. & $\begin{array}{l}\text { "...jornalista inglês que residiu em Israel durante sete anos na } \\
\text { qualidade de correspondente do Observer de Londres e da } \\
B B C \text {. Colaborou também no Jerusalem Post..." } 407\end{array}$ & $\begin{array}{l}\text { 1. "Ben Gurion e o novo Panorama Político } \\
\text { em Israel", In: Comentário, 1960, n. 2, ano I, } \\
\text { pp. 5-16. }\end{array}$ \\
\hline SHERMAN, John. & Ensaísta de Chicago. & $\begin{array}{l}\text { 1. "Martin Buber: o não-conformista judeu”, } \\
\text { In: Comentário, Ano VI, n. 2, 1965, pp. 132- } \\
\text { 135. }\end{array}$ \\
\hline $\begin{array}{l}\text { SHNAIDERMAN, S. } \\
\text { L. }\end{array}$ & $\begin{array}{l}\text { Escritor, jornalista e ensaísta. Escrevia em revistas } \\
\text { americanas regularmente e colaborava com o jornal iídiche } \\
\text { Day-Morning Journal. Escreveu: The Warsaw Heresy e } \\
\text { Between Fear and Hope. }\end{array}$ & $\begin{array}{l}\text { 1. “llya Ehrenburg: revisão ou redenção?", } \\
\text { In: Comentário, n. 1, Ano X, 1969, pp. 15- } \\
\text { 30. }\end{array}$ \\
\hline SIEGMAN, Henry. & $\begin{array}{l}\text { Especialista em assuntos do Oriente Médio, foi encarregado } \\
\text { de estudar os aspectos das questões internacionais nas } \\
\text { relações comunitárias para o Conselho Consultivo de } \\
\text { Relações Comunitárias dos Estados Unidos. Colaborava } \\
\text { noMiddle East Journal Muslim World e New International Year } \\
\text { Book. }\end{array}$ & $\begin{array}{l}\text { 1. "Árabes e Judeus: o encontro histórico", } \\
\text { In: Comentário, Ano VII, n. 2, 1966, pp. 150- } \\
\text { 159. }\end{array}$ \\
\hline $\begin{array}{l}\text { STEINBACH, } \\
\text { Alan. }\end{array}$ & Rabino. Líder espiritual no Brooklin, Nova Iorque. & $\begin{array}{l}\text { 1. "Democracia: a medida do homem", In: } \\
\text { Comentário, 1965, n. 2, ano VI, pp. 110- } \\
\text { 114. }\end{array}$ \\
\hline $\begin{array}{l}\text { SUZKEWER, } \\
\text { Abraham. }\end{array}$ & $\begin{array}{l}\text { Poeta í́diche preso durante a guerra no gueto de Vilna. } \\
\text { Combateu com os guerrilheiros e foi chamado como uma das } \\
\text { principais testemunhas no processo contra os nazistas em }\end{array}$ & $\begin{array}{l}\text { 1. "Diálogos com Peretz Markish", In: } \\
\text { Comentário, 1961, n 1, ano II, pp. 78-83. }\end{array}$ \\
\hline
\end{tabular}

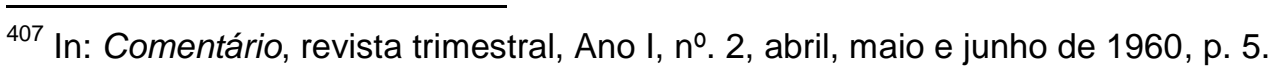




\begin{tabular}{|c|c|c|}
\hline & $\begin{array}{l}\text { Nuremberg. Foi diretor da revista em língua iídiche Di Goldene } \\
\text { Keit. }\end{array}$ & \\
\hline WEIGHTMAN, J. G. & $\begin{array}{l}\text { Prof. de Literatura Francesa no King's College, Londres. } \\
\text { Colaborou para vários periódicos britânicos. Foi redator do } \\
\text { The Twentieth Century. Especialista em civilização francesa. }\end{array}$ & $\begin{array}{l}\text { 1. "A Nova Onda na Cultura Francesa", In: } \\
\text { Comentário, 1961, n 2, ano II, pp. 124-134. }\end{array}$ \\
\hline WEINER, Herbert & $\begin{array}{l}\text { Rabino e ensaísta norte-americano. O rabino Weiner não } \\
\text { compartilhava a crença de seu movimento de que o judaísmo } \\
\text { reformista (liberal) era necessariamente um presente de Deus } \\
\text { para o Estado Judeu }{ }^{408} \text {. }\end{array}$ & $\begin{array}{l}\text { 1. "A Bíblia dos Israelenses - O Sagrado e } \\
\text { o Profano", In: Comentário, 1960, n 1, ano I, } \\
\text { pp. 21-33. }\end{array}$ \\
\hline $\begin{array}{l}\text { YAARI, Yehuda. } \\
\text { 1900/ } \\
\text { (Polônia/) }\end{array}$ & $\begin{array}{l}\text { Escritor de romances contos e dramas. Em } 1920 \text { chegou na } \\
\text { Palestina e foi um dos fundadores do kibutz Beth-Alfa no vale } \\
\text { de Jezréel, ganhando a vida como pastor. Foi então para os } \\
\text { Estados Unidos onde estudou três anos voltando para Israel e } \\
\text { se formando pela Universidade Hebraica de Jerusalém. } \\
\text { Recebeu o Prêmio Ussischkin em } 1951 \text {. }\end{array}$ & $\begin{array}{l}\text { 1. O Julgamento de Salomão, In: } \\
\text { Comentário, 1960, n 3, ano I, pp. } 78-89\end{array}$ \\
\hline $\begin{array}{l}\text { ZAGORIA, Donald } \\
\text { S. }\end{array}$ & $\begin{array}{l}\text { Professor-assistente de administração e membro do Instituto } \\
\text { de Pesquisa de Assuntos Comunistas na Universidade de } \\
\text { Columbia. Escreveu para outras revistas, entre elas, a Foreign } \\
\text { Affairs. Escreveu The Sino-soviet Conflict (1962). }\end{array}$ & $\begin{array}{l}\text { 1. "As Tensões na Ásia", In: Comentário, } \\
\text { Ano VI, n. 1, 1965, pp. 5-13. }\end{array}$ \\
\hline
\end{tabular}

${ }^{408}$ Cf. Ruth R. Wisse, a partir de avaliação de artigo do rabino intitulado "A Mission to Israel", Commentary 36 (August 1963): 118. In: "The Jewishness of Commeantary". In: FRIEDMAN, Murray. Commentary in American Life. Philadelphia: Temple University Press, p. 66. 


\begin{tabular}{|c|c|c|c|c|}
\hline \multicolumn{5}{|c|}{ Comentário: Diretoria, Conselho Editorial, Secretaria de Redação, IBJCD e colaboradores da Seção "Bibliografia" } \\
\hline $\begin{array}{l}\text { Nome, Data e Lugar } \\
\text { de Nascimento }\end{array}$ & $\begin{array}{l}\text { Profissão/ Carreira; } \\
\text { Atuação Junto à Comunidade Judaica; } \\
\text { Reconhecimento Social e cultural; Atuação em } \\
\text { Jornais e Revistas; Obra/Gênero }\end{array}$ & $\begin{array}{l}\text { Colaborou com } \\
\text { artigos ou } \\
\text { escreveu na Seção } \\
\text { Bibliografia da } \\
\text { revista }\end{array}$ & $\begin{array}{l}\text { Cargos que } \\
\text { ocupou na revista }\end{array}$ & $\begin{array}{l}\text { Cargos que } \\
\text { ocupou no } \\
\text { Instituto Brasileiro- } \\
\text { Judaico de Cultura } \\
\text { e Divulgação }\end{array}$ \\
\hline $\begin{array}{l}\text { ALBAGLI, Isaac. } \\
/ 1961\end{array}$ & $\begin{array}{l}\text { Líder da comunidade Sefaradita do Rio de } \\
\text { Janeiro. Foi presidente do Lion's Club e do } \\
\text { Centro Israelita Brasileiro }{ }^{409} \text {. }\end{array}$ & & & $\begin{array}{l}\text { Primeiro } \\
\text { Presidente (até } \\
\text { 1961). }\end{array}$ \\
\hline AMARAL, Rubens. & $\begin{array}{l}\text { Advogado e Jornalista de destaque que trabalhou } \\
\text { na BBC de Londres por oito anos. Assumiu o } \\
\text { nome de Rubens Amaral no Brasil, chamando-se } \\
\text { antes Isaac Ruben Israel. }{ }^{410}\end{array}$ & & $\begin{array}{l}\text { Membro } \quad \text { do } \\
\text { Conselho } \\
\text { Editorial } \\
1970)\end{array}$ & \\
\hline $\begin{array}{l}\text { ANTÔNIO, João. } \\
\text { (colaborador da } \\
\text { seção "Bibliografia") }\end{array}$ & & $\begin{array}{l}\text { 1961: n. 4; 1962: n. } \\
2,\end{array}$ & & \\
\hline $\begin{array}{l}\text { ASTOR, Charles } \\
\text { (colaborador da } \\
\text { seção "Bibliografia") }\end{array}$ & $\begin{array}{l}\text { Instrutor na Escola de Aeronáutica, lecionava } \\
\text { ocasionalmente nos Estágios Internacionais } \\
\text { organizados pelo Ministério da Educação e } \\
\text { Cultura. Escreveu contos e artigos, assim como } \\
\text { programas de rádio e televisão. }\end{array}$ & $\begin{array}{l}\text { 1960: n. 2; 1962: n. } \\
\text { 2, 4; 1963: n. } 1 .\end{array}$ & & \\
\hline $\begin{array}{l}\text { AYALA, Walmir. } \\
\text { (colaborador da } \\
\text { seção "Bibliografia") }\end{array}$ & & $\begin{array}{l}\text { 1964: n. 3; 1965: n. } \\
2,4 .\end{array}$ & & \\
\hline $\begin{array}{l}\text { BARBOSA, João } \\
\text { Alexandre. } \\
\text { (colaborador da } \\
\text { seção "Bibliografia") }\end{array}$ & & 1961: n. 4. & & \\
\hline $\begin{array}{l}\text { BARRETO, Elsa } \\
\text { Fichman. }\end{array}$ & & & Assistente (1970) & \\
\hline
\end{tabular}

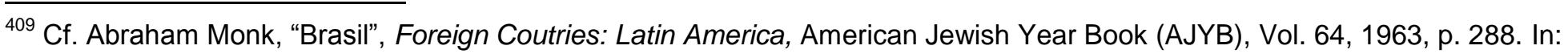
http://www.ajcarchives.org/AJC DATA/Files/1963 8 LatAmerica.pdf, acesso em 6/04/2011.

${ }^{410}$ Rachel Mizrahi, Imigrantes Judeus do Oriente Médio - São Paulo e no Rio de Janeiro, São Paulo, Ateliê Editorial, 2003, p. 73 


\begin{tabular}{|c|c|c|c|c|}
\hline $\begin{array}{lr}\text { BATISTA, José. } & \\
\text { (colaborador } & \text { da } \\
\text { seção "Bibliografia") }\end{array}$ & & 1966: n. 2, 4. & & \\
\hline BECKER, Scholem & & & & $\begin{array}{l}2^{0} \text {. Tesoureiro } \\
(1962, \text { n. } 4-1964)\end{array}$ \\
\hline BELOCH, Gregório. & & & & $\begin{array}{l}\text { Membro da } \\
\text { Diretoria (1964) }\end{array}$ \\
\hline $\begin{array}{l}\text { BERLINER, } \\
\text { Bernardo. }\end{array}$ & & & & $\begin{array}{lr}\text { Membro } & \text { do } \\
\text { Conselho } & \text { Fiscal } \\
(1965-1971) & \end{array}$ \\
\hline $\begin{array}{l}\text { BERNARDES, Nilo. } \\
\text { (colaborador da } \\
\text { seção "Bibliografia") }\end{array}$ & Geógrafo. & 1960: n. 1. & & \\
\hline $\begin{array}{l}\text { BERNARDINI, } \\
\text { Aurora Tornoni. } \\
\text { (colaborador da } \\
\text { seção "Bibliografia") }\end{array}$ & & 1970: n. 4. & & \\
\hline $\begin{array}{l}\text { BILDNER, Patrícia } \\
\text { (colaborador da } \\
\text { seção "Bibliografia") }\end{array}$ & & $\begin{array}{l}\text { 1960: n. 2, 4; 1961: } \\
\text { n. } 4 .\end{array}$ & & \\
\hline $\begin{array}{l}\text { BOAS, Henriette. } \\
\text { (colaborador da } \\
\text { seção "Bibliografia") }\end{array}$ & & 1970: n. 2. & & \\
\hline $\begin{array}{l}\text { BOLAFFI, Gabriel. } \\
\text { (colaborador da } \\
\text { seção "Bibliografia") }\end{array}$ & $\begin{array}{l}\text { Sociólogo formado pela Universidade de São } \\
\text { Paulo (USP). Trabalhou na Divisão de estudos e } \\
\text { Pesquisas Sociais do Centro Regional de } \\
\text { Pesquisas Educacionais de São Paulo. Escreveu } \\
\text { artigos para o suplemento literário de O Estado } \\
\text { de São Paulo e para a revista Anhembi. }\end{array}$ & $\begin{array}{l}\text { 1960: n. } 4 \text { (artigo), } \\
\text { 1961: n. 1; 1962: n } \\
\text { 4. }\end{array}$ & $\begin{array}{l}\text { Membro da } \\
\text { Comissão } \\
\text { Editorial de São } \\
\text { Paulo (1962: n. 3- } \\
\text { 1964). Membro } \\
\begin{array}{l}\text { da comissão } \\
\text { Editorial (1964- } \\
\text { 1968) }\end{array}\end{array}$ & \\
\hline BORGER, Hans. & & & & $\begin{array}{lr}\text { Membro } & \text { da } \\
\text { Comissão } & \text { de } \\
\text { Programação } & \text { e } \\
\text { Planejamento } & \\
\end{array}$ \\
\hline
\end{tabular}




\begin{tabular}{|c|c|c|c|}
\hline & & & (1971) \\
\hline BRAKARZ, Jack. & & & $\begin{array}{lr}\text { Membro ro } & \text { do } \\
\text { Conselho } & \text { Fiscal } \\
(1965-1970) & \end{array}$ \\
\hline $\begin{array}{lr}\text { BRASIL, } & \text { Assis. } \\
\text { colaborador } & \text { da } \\
\text { seção "Bibliografia") }\end{array}$ & & 1968: n.4. & \\
\hline $\begin{array}{l}\text { CARMICHAEL, Joel } \\
\text { (colaborador da } \\
\text { seção "Bibliografia") }\end{array}$ & $\begin{array}{lll}\text { Colaborador de } & \text { Commentary. } & \text { Historiador } \\
\text { americano, editor da revista sionista } & \text { Midstream } \\
\text { por } 24 \text { anos (1975-88) e tradutor. } & \end{array}$ & 1960: n. 1. & \\
\hline $\begin{array}{l}\text { CARNEIRO, Edison. } \\
\text { (colaborador da } \\
\text { seção "Bibliografia") }\end{array}$ & Crítico literário. & 1960: n. 3. & \\
\hline $\begin{array}{l}\text { CESAR, Waldo A. } \\
\text { (colaborador da } \\
\text { seção "Bibliografia") }\end{array}$ & & 1968: n. 2. & \\
\hline COHEN, Abraham. & & & $\begin{array}{ll}2^{0}= & \text { Tesoureiro } \\
(1962)\end{array}$ \\
\hline COHEN, Aron. & & & $\begin{array}{lr}\text { Membro } & \text { do } \\
\text { Conselho } & \text { Fiscal } \\
(1970) & \end{array}$ \\
\hline COHEN, Umberto. & & & $\begin{array}{lr}\text { Membro ro } & \text { do } \\
\text { Conselho } & \text { Fiscal } \\
(1960-1964) & \end{array}$ \\
\hline COHEN, Vivian & & & $\begin{array}{l}\text { Diretora Cultural } \\
(1965-1971)\end{array}$ \\
\hline $\begin{array}{l}\text { CONRADO, } \\
\text { Aldomar. } \\
\text { (colaborador da } \\
\text { seção "Bibliografia") }\end{array}$ & & 1962: 4. & \\
\hline $\begin{array}{l}\text { CUDISCHEVITCH, } \\
\text { Leon. (colaborador } \\
\text { da } \\
\text { "Bibliografia") }\end{array}$ & & $\begin{array}{l}\text { 1961: n. 4; 1962: n. } \\
\text { 1; 1965: n. 3, 4; } \\
\text { 1967: n. 1; 1968: n. } \\
\text { 3. }\end{array}$ & \\
\hline
\end{tabular}




\begin{tabular}{|c|c|c|c|c|}
\hline $\begin{array}{l}\text { DAICHES, } r \text { David. } \\
\text { (colaborador da } \\
\text { seção "Bibliografia") }\end{array}$ & $\begin{array}{l}\text { Deão da Escola de Estudos Ingleses e } \\
\text { Americanos da Escola de Sussex. }\end{array}$ & $\begin{array}{l}\text { 1964: n. 2. 1966: n. } \\
1 .\end{array}$ & & \\
\hline $\begin{array}{l}\text { DAWIDOWICZ, } \\
\text { Lucy, S. } \\
\text { (colaborador da } \\
\text { seção "Bibliografia") }\end{array}$ & & 1961: n. 2 & & \\
\hline $\begin{array}{l}\text { DECTER, Midge. } \\
\text { (colaborador da } \\
\text { seção "Bibliografia") }\end{array}$ & & 1962: n. 1 & & \\
\hline DEMAJO, Stevan. & & & & $\begin{array}{l}\text { Bibliotecário } \\
\text { (1961); Membro } \\
\text { do Conselho } \\
\text { Fiscal (1962- } \\
\text { 1964); Membro da } \\
\text { Comissão de } \\
\text { Programação e } \\
\begin{array}{l}\text { Planejamento } \\
\text { (1971) }\end{array}\end{array}$ \\
\hline $\begin{array}{l}\text { DOURADO, } \\
\text { Mecenas. } \\
\text { (colaborador da } \\
\text { seção "Bibliografia") }\end{array}$ & & 1960: n. 2; & & \\
\hline EMANUEL, Isaac. & & & & $\begin{array}{lr}\text { Membro } & \text { do } \\
\text { Conselho } & \text { Fiscal } \\
(1960) . & \end{array}$ \\
\hline FEITLER, Rudi. & & & & $\begin{array}{lr}\text { Membro } & \text { do } \\
\text { Conselho } & \text { Fiscal } \\
(1960) & \\
\end{array}$ \\
\hline FILHO, Ferreira. & & & $\begin{array}{l}\text { Assistente } \\
\text { Editorial (1969) }\end{array}$ & \\
\hline $\begin{array}{l}\text { FILHO, Leodegário } \\
\text { A. de Azevedo. } \\
\text { (colaborador da } \\
\text { seção "Bibliografia") }\end{array}$ & & 1966: n. 3. & & \\
\hline
\end{tabular}




\begin{tabular}{|c|c|c|c|c|}
\hline $\begin{array}{l}\text { FROMM, Ernst. } \\
\text { (colaborador da } \\
\text { seção "Bibliografia") }\end{array}$ & & 1961: n. 1, & & \\
\hline $\begin{array}{l}\text { GALVÃO, Walnice } \\
\text { Nogueira } \\
\text { (Colaboradora da } \\
\text { seção "Bilbiografia"). }\end{array}$ & & 1965: n. 3. & & \\
\hline $\begin{array}{l}\text { GARCIA, Ana Lucia. } \\
\text { (colaboradora da } \\
\text { seção "Bibliografia") }\end{array}$ & & 1967: n. 2. & & \\
\hline $\begin{array}{l}\text { GARCIA, Othon } \\
\text { Moacyr. } \\
\text { (Colaborador da } \\
\text { seção "Bilbiografia"). }\end{array}$ & & 1964: n. 1. & & \\
\hline GENOVESI, Walter. & & & $\begin{array}{l}\text { Diagramação } \\
\text { (1969) } \\
\text { Produção (1970) }\end{array}$ & \\
\hline $\begin{array}{l}\text { GERSEN, Bernardo. } \\
\text { (colaborador da } \\
\text { seção "Bibliografia") }\end{array}$ & Ensaísta e crítico literário & 1960: n. 1, 3; & & \\
\hline GLEISER, Izaac. & & & & $\begin{array}{l}\text { Diretor Cultural } \\
(1962-1964) ; 19 \\
\text { Tesoureiro (1965- } \\
1971) \text {. }\end{array}$ \\
\hline $\begin{array}{l}\text { GOFMAN, Eny Léa } \\
\text { Gass. }\end{array}$ & & $\begin{array}{l}\text { 1962: n. 3; 1964: n. } \\
4 .\end{array}$ & & \\
\hline $\begin{array}{l}\text { GOLFFING, Francis } \\
\text { (colaborador da } \\
\text { seção "Bibliografia") }\end{array}$ & $\begin{array}{l}\text { Colaborador de Commentary. } \\
\text { Professor } \\
\text { acadêmico da área de cultura inglesa, poeta. }\end{array}$ & 1960: n. 1; & & \\
\hline $\begin{array}{l}\text { GOMES, Eugênio. } \\
\text { (colaborador da } \\
\text { seção "Bibliografia") }\end{array}$ & & 1966: n. 4. & & \\
\hline $\begin{array}{l}\text { GRAVES, Robert. } \\
\text { (colaborador da } \\
\text { seção "Bibliografia") }\end{array}$ & Colaborador de Commentary. & 1960: n. 4; & & \\
\hline
\end{tabular}




\begin{tabular}{|c|c|c|c|c|}
\hline $\begin{array}{l}\text { GRAZIANI-LEVY, } \\
\text { Roberto }\end{array}$ & & & $\begin{array}{lr}\text { Membro } & \text { do } \\
\text { Conselho } \\
\text { Editorial } \\
1961)\end{array}$ & $\begin{array}{lr}10 . & \text { Vice- } \\
\text { presidente } & (1960- \\
1961) & \end{array}$ \\
\hline $\begin{array}{l}\text { GRIESSMANN, } \\
\text { Walter. }\end{array}$ & & & $\begin{array}{lr}\text { Membro } & \text { do } \\
\text { Conselho } & \\
\text { Editorial } & \text { (1960- } \\
1968) & \end{array}$ & $\begin{array}{lr}2^{0} . & \text { Vice- } \\
\text { Presidente } & \text { (1960- } \\
\text { 1961); 1ㅇ. Vice- } \\
\text { Presidente (1962- } \\
\text { 1964) }\end{array}$ \\
\hline $\begin{array}{l}\text { GRUENBAUM, G. } \\
\text { E. Von. (colaborador } \\
\text { da } \\
\text { "Bibliografia") }\end{array}$ & Colaborador de Commentary. & 1960: n. 2; & & \\
\hline GUINSBURG, Jacó. & $\begin{array}{l}\text { Editor e tradutor. Crítico de literatura iídiche. Foi } \\
\text { colaborador do "Suplemento Literário" d'O Estado } \\
\text { de São Paulo, tendo editado uma antologia da } \\
\text { literatura hebraica naquele suplemento. Publicou } \\
\text { em Comentário tradução de poesias do poeta } \\
\text { nacional hebreu Haim Bialik. É tradutor ainda de } \\
\text { Peretz, Heine, Descartes e Sartre para o } \\
\text { português. Publicou As Portas de Sion e Motivos. } \\
\text { Fundador da Editora Perspectiva em São Paulo } \\
\text { (1966-até os dias de hoje). }\end{array}$ & $\begin{array}{l}\text { 1961: n. 2; 1962: n. } \\
\text { 4; 1965: n.1; 1966: } \\
\text { n. 1, 2. }\end{array}$ & $\begin{array}{lr}\text { Membro } & \text { da } \\
\text { Comissão } & \\
\text { Consultiva de } & \text { de } \\
\text { São Paulo (1962, } \\
\text { n. 2); Membro da } \\
\text { Comissão } & \\
\text { Editorial de } & \text { São } \\
\text { Paulo } & \\
(19621964) . & \\
\text { Membro } & \text { da } \\
\text { Comissão } & \\
\text { Editorial } & - \\
\text { presidente } & \text { a } \\
\text { partir de } & 1969 \\
\text { (1964-1970). }\end{array}$ & \\
\hline HABERER, Fritz. & & & & $\begin{array}{ll}2^{\circ} . & \text { Tesoureiro } \\
(1961) & \end{array}$ \\
\hline $\begin{array}{ll}\text { HASSON, } & \text { Hélio } \\
\text { Gilberto. } & \end{array}$ & & & & $\begin{array}{lr}\text { Membro } & \text { da } \\
\text { Comissão } & \text { de } \\
\text { Programação } & \text { e } \\
\text { Planejamento } & \\
(1971) & \\
\end{array}$ \\
\hline
\end{tabular}




\begin{tabular}{|c|c|c|c|c|}
\hline $\begin{array}{l}\text { HEILBORN, } \\
\text { Gunther. }\end{array}$ & & & & $\begin{array}{l}2^{\circ} \text {. Secretário da } \\
\text { Diretoria (1961- } \\
\text { 1964). Membro do } \\
\text { Conselho Fiscal } \\
(1965-1971)\end{array}$ \\
\hline $\begin{array}{l}\text { HEILBORN, Ivette } \\
\text { Khouri. }\end{array}$ & & & $\begin{array}{l}\text { Coordenadora } \\
(1971)\end{array}$ & \\
\hline HEILIG, Otto. & & & & $\begin{array}{l}\text { Bibliotecário } \\
\text { (1971) }\end{array}$ \\
\hline HERZBERG, Rolf. & & & & $\begin{array}{lr}\text { Membro } & \text { da } \\
\text { Comissão } & \text { de } \\
\text { Programação } & \text { e } \\
\text { Planejamento } & \\
(1971) & \end{array}$ \\
\hline $\begin{array}{l}\text { HILEL, David Bem. } \\
\text { (colaborador da } \\
\text { seção "Bibliografia") }\end{array}$ & & 1968: n. 2. & & \\
\hline $\begin{array}{l}\text { HIRSHBERG, } \\
\text { Alfred. } \\
\text { (Alemanha) } \\
(-111 \\
(1971)\end{array}$ & $\begin{array}{l}\text { Judeu alemão radicado em São Paulo a partir de } \\
1940 \text { e um dos maiores responsáveis pela } \\
\text { criação, administração, organização de entidades } \\
\text { judaicas e publicações judaicas no Brasil. } \\
\text { Orientador experiente e formador de uma } \\
\text { geração de líderes judaicos. Alfred Hirschberg } \\
\text { exerceu atividade jornalística no Brasil e no } \\
\text { exterior (Argentina, Estados Unidos e Inglaterra). } \\
\text { Foi o editor da Crônica Israelita por muitos anos e } \\
\text { participou da criação do Centro de Estudos } \\
\text { Judaicos da USP. Era amigo de Fritz Pinkuss, } \\
\text { tendo exercido o cargo de superintendente da } \\
\text { CIP. O Arquivo Histórico Judaico-Brasileiro }\end{array}$ & & 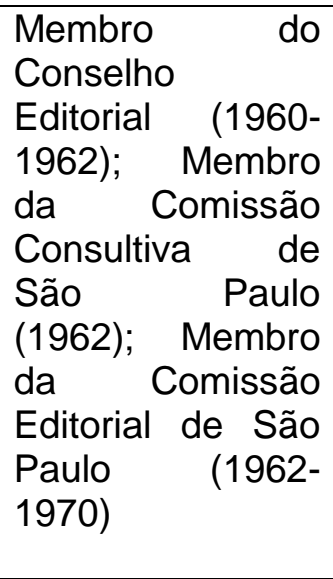 & $\begin{array}{l}\text { Diretor } \\
\text { Conselheiro } \\
\text { (1971) }\end{array}$ \\
\hline
\end{tabular}

$\overline{{ }^{411} F r i t z ~ P i n k u s s, ~ O p . ~ c i t ., ~ 1989, ~ p . ~ 92 ; ~ I n t r o d u c ̧ a ̃ o ~ d e ~ N a c h m a n ~ F a l b e l ~ a o ~ I n v e n t a ́ r i o ~ S u m a ́ r i o ~ d o ~ F u n d o ~ D r . ~ A l f r e d ~ H i r s c h b e r g, ~ A H J B: ~ S a ̃ o ~ P a u l o: ~ 1989, ~}$ pp. 1-4;

Nachman Falbel, Judeus no Brasil, Estudos e Notas, São Paulo: Humanitas; Edusp, 2008, p. 38, nota 26. 


\begin{tabular}{|c|c|c|c|}
\hline & $\begin{array}{l}\text { (AHJB) possui documentos reunidos por esse } \\
\text { intelectual e ativista, o Fundo Dr. Alfred } \\
\text { Hirschberg (1901-1971), considerado um dos } \\
\text { mais importantes do seu acervo. Hirschberg } \\
\text { participou da Confederação Israelita do Brasil, da } \\
\text { Liga dos Direitos Humanos da B'nai B'rith, do } \\
\text { World Council of Synagogues, CENTRA } \\
\text { (Associação de Comunidades O Organizações na } \\
\text { América Latina originária de imigrantes vindos da } \\
\text { Europa Central) e, finalmente, e o que nos } \\
\text { interessa mais de perto, do AJC e da revista } \\
\text { Comentário. }\end{array}$ & & \\
\hline $\begin{array}{l}\text { HIRSHBERG, A. } \\
\text { Irene } \\
\text { (colaboradora da } \\
\text { seção "Bibliografia") }\end{array}$ & & 1960: n. 4; & \\
\hline HOULI, Jacques. & & & $\begin{array}{l}\text { Diretor Cultural } \\
(1960)\end{array}$ \\
\hline $\begin{array}{l}\text { IANNONE, Carlos } \\
\text { Alberto. } \\
\text { Colaborador da } \\
\text { seção "Bibliografia") }\end{array}$ & & 1967: n. 2 & \\
\hline ISRAEL, José. & & & \begin{tabular}{lr}
\multicolumn{2}{l}{ Tesoureiro (1960); } \\
10 r & Tesoureiro \\
$(1961) ;$ & Membro \\
do & Conselho \\
Fiscal & $(1962-1964)$ \\
\end{tabular} \\
\hline $\begin{array}{l}\text { JEAN, Yvonne } \\
\text { (colaborador da } \\
\text { seção "Bibliografia") }\end{array}$ & Escritora e jornalista. & $\begin{array}{l}\text { 1960: n. 2; 1961: n. } \\
3\end{array}$ & \\
\hline $\begin{array}{l}\text { JERUSALMI, } \\
\text { Marcel. }\end{array}$ & & & $\begin{array}{lr}\text { Membro } & \text { do } \\
\text { Conselho } & \text { Fiscal } \\
(1962-1964) ; & \\
\text { Membro } & \text { da } \\
\text { Comissão } & \text { de }\end{array}$ \\
\hline
\end{tabular}




\begin{tabular}{|c|c|c|c|}
\hline & & & $\begin{array}{l}\text { Programação e } \\
\text { Planejamento } \\
(1971)\end{array}$ \\
\hline $\begin{array}{l}\text { JOSEF, Bella. } \\
\text { (colaborador da } \\
\text { seção "Bibliografia") }\end{array}$ & $\begin{array}{l}\text { Crítica literária. Professora de Literatura Hispano- } \\
\text { Americana da Faculdade de Filosofia da } \\
\text { Universidade Federal do Rio de Janeiro e } \\
\text { Catedrática Honorária da Universidade de San } \\
\text { Marcos no Peru. Conferencista. Jornalista. }\end{array}$ & $\begin{array}{l}\text { 1965: n. 2, 3, 4; } \\
\text { 1966: n. 2, 3; 1967: } \\
\text { n. 3; 1968: n. 3; } \\
\text { 1970: n. 4. }\end{array}$ & \\
\hline \begin{tabular}{|lr} 
JÚNIOR, & Manuel \\
Diégues & \\
1912-1991 & \\
(Maceió - AL/ & Rio \\
de Janeiro - & RJ) \\
(colaborador da \\
seção "Bibliografia")
\end{tabular} & $\begin{array}{l}\text { Antropólogo e sociólogo brasileiro. Era professor } \\
\text { de Antropologia Cultural e Etnografia do Brasil da } \\
\text { PUC - Rio de Janeiro quando escreveu o seu } \\
\text { primeiro artigo para Comentário em 1960. Nesta } \\
\text { época já tinha várias obras publicadas, tendo } \\
\text { escrito para a UNESCO estudos sobre a } \\
\text { assimilação do imigrante italiano no Brasil e } \\
\text { sobre a educação do imigrante. Foi presidente da } \\
\text { Associação Latino-Americana de Sociologia } \\
\text { (1967-1969) e da Associação Brasileira de } \\
\text { Antropologia (1966-1968). Escreveu diversos } \\
\text { ensaios e estudos sobre antropologia, sociologia } \\
\text { e problemas culturais e regionais do Brasil. Obra: } \\
\text { Etnias e Culturas no Brasil; O Engenho de Açúcar } \\
\text { no Nordeste; Introducción a La Sociologia } \\
\text { Regional (México, 1954); Estudos de Relações } \\
\text { de cultura no Brasil; Assimilação Cultural do } \\
\text { Imigrante no Brasil (com Artur H. Neiva); } \\
\text { Assimilação cultural do Imigrante (com Pe. } \\
\text { Fernando Bastos de Ávila; Regiões Culturais do } \\
\text { Brasil (1960) }\end{array}$ & $\begin{array}{l}\text { 1960: n. 2; 1965: n. } \\
\text { 1, 3; 1966: n. 2; } \\
\text { 1967: n. 1; 1968: n. } \\
\text { 3. }\end{array}$ & \\
\hline $\begin{array}{l}\text { JÚNIOR, Raimundo } \\
\text { Magalhães. } \\
\text { (colaborador da } \\
\text { seção "Bibliografia") } \\
\end{array}$ & $\begin{array}{l}\text { Teatrólogo, publicista, biógrafo, historiador, } \\
\text { ensaísta e tradutor. Membro da ABL e do IHGB. }\end{array}$ & $\begin{array}{l}\text { 1960: n. 1; 1962: n. } \\
\text { 2; 1964: n. } 3 .\end{array}$ & \\
\hline KAISER, Max. & & & $\begin{array}{lr}\text { Membro } & \text { do } \\
\text { Conselho } & \text { Fiscal } \\
\end{array}$ \\
\hline
\end{tabular}




\begin{tabular}{|c|c|c|c|c|}
\hline & & & & $\begin{array}{l}(1960-1961) \text {. } \\
\text { Consta como } \\
\text { falecido no n. } 4 \text { do } \\
\text { ano de } 1961 .\end{array}$ \\
\hline $\begin{array}{l}\text { KANNER. Richard. } \\
\text { (colaborador da } \\
\text { seção "Bibliografia") }\end{array}$ & & 1969: n. 4. & & \\
\hline KAUFMANN, Adolf . & & & & $\begin{array}{lr}\text { Membro } & \text { do } \\
\text { Conselho } & \text { Fiscal } \\
(1961-1964) & \end{array}$ \\
\hline KAUFFMANN, Nuni. & & & & $\begin{array}{l}10 \text { Tesoureiro } \\
(1962-1964)\end{array}$ \\
\hline KOOGAN, A. & $\begin{array}{l}\text { Editor. Recebeu a medalha de mérito da } \mathrm{ABL} \text { em } \\
1963 .\end{array}$ & & $\begin{array}{l}\text { Membro } \quad \text { da } \\
\text { Comissão } \\
\text { Editorial } \\
1970)\end{array}$ & \\
\hline KRAUSZ, Rosa R. & $\begin{array}{l}\text { Socióloga. Foi Instrutora da Faculdade de higiene } \\
\text { e Saúde Pública da Universidade de São Paulo e } \\
\text { da acessória Técnica da Assessoria do Bem } \\
\text { Estar Social da Prefeitura de São Paulo. }\end{array}$ & 1969: n. 4. & $\begin{array}{lr}\text { Membro } & \text { da } \\
\text { Comissão } & \\
\text { Editorial } & (1969- \\
1970) & \text { e } \\
\text { responsável pela } \\
\text { Secretaria } \\
\text { Editorial. }\end{array}$ & \\
\hline $\begin{array}{l}\text { KRINKER, } \\
\text { Raymond. }\end{array}$ & & & & $\begin{array}{lr}\text { Membro } & \text { da } \\
\text { Comissão } & \text { de } \\
\text { Programação } & \text { e } \\
\text { Planejamento } & \\
(1971) & \end{array}$ \\
\hline LÁFER, Celso. & $\begin{array}{l}\text { Tinha } 21 \text { anos e era estudante da Faculdade de } \\
\text { Direito e da Faculdade de Filosofia, Ciências e } \\
\text { Letras da Universidade de São Paulo quando } \\
\text { escreveu pela primeira vez para a revista. Havia } \\
\text { obtido o Prêmio Gastão Vidigal de } 1960 \\
\text { destinado ao melhor aluno de Economia Política } \\
\text { da F.D. Era redator da revista Onze de Agôsto e }\end{array}$ & $\begin{array}{l}\text { 1962: n. } 1 ; 1964: \text { n. } \\
2 .\end{array}$ & $\begin{array}{l}\text { Membro da } \\
\text { Comissão } \\
\text { Editorial de São } \\
\text { Paulo (1964) } \\
\text { Membro da } \\
\text { Comissão } \\
\text { Editorial (1964- }\end{array}$ & \\
\hline
\end{tabular}




\begin{tabular}{|c|c|c|c|c|}
\hline & $\begin{array}{l}\text { Diretor cultural do centro acadêmico que levava o } \\
\text { mesmo nome da revista. }\end{array}$ & & 1970) & \\
\hline $\begin{array}{l}\text { LARA, Jorge Torres } \\
\text { (colaborador da } \\
\text { seção "Bibliografia") }\end{array}$ & & 1961: n. 2, & & \\
\hline $\begin{array}{l}\text { LEITE, } \\
\text { Uchôa. }\end{array}$ & & $\begin{array}{l}\text { 1961: n. 4; 1962: n. } \\
\text { 1, 2, }\end{array}$ & & \\
\hline $\begin{array}{l}\text { LEMLE, Henrique } \\
\text { (Heinrich) }{ }^{412} \text {. } \\
\text { (Augsburgo } \\
\text { Alemanha/ ) }\end{array}$ & $\begin{array}{l}\text { Rabino. Sua formação se deu nos seminários } \\
\text { rabínicos e nas Universidades de Berlim, Breslau } \\
\text { e Wuerzburg. Esteve no campo de concentração } \\
\text { de Bunchenvald antes de sua vinda ao Brasil em } \\
\text { dezembro de 1940. Exerceu o cargo de professor } \\
\text { de civilização hebraica na Faculdade de Filosofia } \\
\text { da UFRJ e recebeu o título de doutor honoris } \\
\text { causa em teologia pela Universidade Hebraica de } \\
\text { Jerusalém. Foi líder espiritual da Associação } \\
\text { religiosa Israelita (ARI) no Rio de Janeiro e } \\
\text { parceiro de trabalho de Fritz Pinkuss da CIP em } \\
\text { São Paulo. As duas eram "organizações-irmãs", } \\
\text { segundo Pinkuss. Lemle veio ao Brasil a convite } \\
\text { de Pinkuss e como enviado do World Union for } \\
\text { Progressive Judaism. Ele foi o primeiro rabino } \\
\text { liberal do Rio de Janeiro no final dos anos } 1930 \text { e } \\
\text { um importante interlocutor, constantemente } \\
\text { ouvido pelas autoridades do governo brasileiro } \\
\text { durante a II Guerra. Escreveu O Drama Judaico e } \\
\text { Jornada sem fim. }\end{array}$ & $\begin{array}{l}\text { 1960: n. 2; 1971: n. } \\
1 .\end{array}$ & $\begin{array}{l}\text { Membro } \quad \text { do } \\
\text { Conselho } \\
\text { Editorial } \\
1970)\end{array}$ & \\
\hline $\begin{array}{l}\text { LEONARDOS, } \\
\text { Stella. } \\
\text { (colaboradora da } \\
\text { seção "Bibliografia") }\end{array}$ & $\begin{array}{l}\text { Escritora e tradutora. Escreveu poesia, literatura } \\
\text { infantil, ensaio, peça de teatro, romance. } \\
\text { Colaboradora permanente da revista como crítica } \\
\text { de livros. Foi secretária da União Brasileira de }\end{array}$ & $\begin{array}{l}\text { 1964: ns. 2, 3, 4; } \\
\text { 1965: n. 1, 2, 3, 4; } \\
\text { 1966: n. 1, 2, 3, 4; } \\
\text { 1967: n. 2, 3. }\end{array}$ & & \\
\hline
\end{tabular}

\footnotetext{
${ }^{412}$ Fritz Pinkuss, Op. cit., 1989, p. 91; Henrique Veltman, A História dos Judeus no Rio de Janeiro. Rio de Janeiro, Editora Expressão e Cultura, 1998, p. 146; Diego Terry, "Da Alemanha para o Rio", Boletim ASA n. 92, jan-fev. de 2005 em http://www.asa.org.br/boletim/92/92 h1.htm, acesso em 4/02/2011.
} 


\begin{tabular}{|c|c|c|c|c|}
\hline & $\begin{array}{l}\text { Escritores. Entre as suas obras estão: } \\
\text { Romanceiro de Estácio, Ar Lírico e Tempos } \\
\text { alados. }\end{array}$ & & & \\
\hline $\begin{array}{l}\text { LIPINER, Elias. (SP) } \\
\text { (colaborador da } \\
\text { seção "Bibliografia") }\end{array}$ & $\begin{array}{l}\text { Advogado, professor e jornalista. Pesquisador da } \\
\text { literatura judaica do período quinhentista, } \\
\text { especialmente Portugal e Espanha. Traduziu } \\
\text { para o ií́diche Consolaçam às Tribulaçoens de } \\
\text { Israel, de Samuel Usque. }\end{array}$ & $\begin{array}{l}\text { 1961: n. 4; 1964: n. } \\
\text { 2,4; 1966: n. 1; } \\
\text { 1967: n. 2. 1968: n. } \\
\text { 2; 1970: n.2. }\end{array}$ & & \\
\hline $\begin{array}{l}\text { LISBOA, Luis } \\
\text { Carlos. } \\
\text { (colaborador da } \\
\text { seção "Bibliografia") }\end{array}$ & & 1967: n. 3. & & \\
\hline LUFTIG, Roman. & & & & $\begin{array}{lr}\text { Membro } & \text { do } \\
\text { Conselho } & \text { Fiscal } \\
(1971) & \\
\end{array}$ \\
\hline $\begin{array}{l}\text { MALAMUD, } \\
\text { Samuel. }\end{array}$ & $\begin{array}{l}\text { Advogado e jornalista carioca. Primeiro cônsul } \\
\text { honorário de Israel no Brasil. Em } 1927 \text { tornou-se } \\
\text { secretário da Biblioteca Israelita Scholem } \\
\text { Aleichem (BIBSA), fundada nos anos de } 1920 \text { e } \\
\text { principal espaço político de reunião da esquerda } \\
\text { judaica carioca a partir de } 1928^{413} \text {. Um dos } \\
\text { fundadores e ativistas do Centro Cultural Brasil- } \\
\text { Israel. Foi eleito Presidente do Executivo da } \\
\text { FIERJ em 1968. }\end{array}$ & $\begin{array}{l}\text { 1961: n. 3; 1962: n. } \\
\text { 3; 1964: n. 2; 1965: } \\
\text { n. } 1 .\end{array}$ & $\begin{array}{lr}\text { Membro } & \text { da } \\
\text { comissão } & \\
\text { Editorial } & \text { (1965- } \\
\text { 1970). } & \end{array}$ & \\
\hline $\begin{array}{l}\text { MARGULIES, } \\
\text { Marcos. }\end{array}$ & $\begin{array}{l}\text { Jornalista. Colaborador de O Estado de São } \\
\text { Paulo e da revista Anhembi. }\end{array}$ & 1962: n. 4. & $\begin{array}{lr}\text { Membro } & \text { da } \\
\text { Comissão } & \\
\text { Consultiva } & \text { de } \\
\text { São Paulo (1962- } \\
\text { 1964); } & \text { Membro } \\
\text { da } & \text { comissão } \\
\text { Editorial } & \text { (1964- } \\
\text { 1968); } & \text { Diretor } \\
\end{array}$ & \\
\hline
\end{tabular}

${ }^{413}$ Cf. Esther Kuperman, "ASA - Gênese e Trajetória da esquerda judaica não sionista carioca". In: Revista Espaço Acadêmico, no 28, Setembro de 2003, Mensal, ISSN 1519.6186 (www.espacoacademico.com.br, acessado em 9/5/2008 e 06/04/2011). 


\begin{tabular}{|c|c|c|c|c|}
\hline & & & Editorial (1971) & \\
\hline $\begin{array}{l}\text { MARTINS, } \\
\text { Henrique. }\end{array}$ & & & $\begin{array}{l}\text { Arte e Produção } \\
\text { (1971) }\end{array}$ & \\
\hline $\begin{array}{lr}\text { MARTINS, Luís. } \\
\text { (Colaborador da } \\
\text { seção "Bilbiografia"). }\end{array}$ & & 1965: n. 2. & & \\
\hline $\begin{array}{l}\text { MATTA, Ary da. } \\
\text { (Colaborador da } \\
\text { seção "Bilbiografia"). }\end{array}$ & & 1964: n.1. & & \\
\hline $\begin{array}{lr}\text { MEDINA, Carlos } \\
\text { Alberto r de. } \\
\text { (colaborador da } \\
\text { seção "Bibliografia") }\end{array}$ & & $\begin{array}{l}\text { 1965: n. 1, 3; } 1966: \\
\text { n. 2; 1968: n. } 4 \text {. }\end{array}$ & & \\
\hline $\begin{array}{l}\text { MEGED, Mati } \\
\text { (Colaborador da } \\
\text { seção "Bilbiografia"). }\end{array}$ & Colaborador de Commentary. & 1960: n. 4; & & \\
\hline $\begin{array}{lr}\text { MELO, } & \text { Paulo } \\
\text { Pereira r de. } \\
\text { (Colaborador } \\
\text { seção "Bilbiografia"). }\end{array}$ & & 1965: n. 2. & & \\
\hline $\begin{array}{l}\text { MENASHÉ, } \\
\text { Matheus. }\end{array}$ & & & & $\begin{array}{ll}\text { Presidente do } & \text { do } \\
\text { Conselho } & \\
\text { Deliberativo } & \\
\left(1960-1970^{414}\right) & \end{array}$ \\
\hline MINDLIN, José. & $\begin{array}{l}\text { Foi presidente da Federação Nacional das } \\
\text { Indústrias. }\end{array}$ & & & $\begin{array}{lr}10 . & \text { Vice- } \\
\text { presidente } & \text { da } \\
\text { Diretoria } & (1965- \\
1971) & \\
\end{array}$ \\
\hline $\begin{array}{lr}\text { MIRANDA, } & \text { Dilmar } \\
\text { Santos } & \text { de. } \\
\text { (colaborador } & \text { da } \\
\text { seção "Bibliografia") }\end{array}$ & & 1967: n. 2 & & \\
\hline MONAT, Olympio. & Romancista. Crítico literário. & 1965: n. 1, 2, 4; & & \\
\hline
\end{tabular}

$\overline{414}$ O Conselho Deliberativo deixa de aparecer a partir do terceiro número da revista do ano de 1962 e volta a aparecer no número 1 de 1963. 


\begin{tabular}{|c|c|c|c|c|}
\hline $\begin{array}{l}\text { (colaborador da } \\
\text { seção "Bibliografia") }\end{array}$ & & 1966: n. 1. & & \\
\hline $\begin{array}{l}\text { MONK, Abraham. } \\
\text { (Colaborador da } \\
\text { seção "Bilbiografia"). }\end{array}$ & $\begin{array}{l}\text { Ensaísta. Monk foi membro do conselho editorial } \\
\text { da revista Comentário desde o seu surgimento e } \\
\text { ligação com o AJC, escrevendo sobre a } \\
\text { comunidade judaica no Brasil no American } \\
\text { Jewish Year Book. Publicou em co-autoria com } \\
\text { Jose Isaacson, Comunidades Judias de Latino } \\
\text { America, Buenos Aires, Comité Judío Americano } \\
\text { Instituto de Relaciones Humanas/Candelabro, } \\
\text { 1968, } 287 \text { pp. }\end{array}$ & 1960: n. 1, 4. & $\begin{array}{lr}\text { Membro } & \text { da } \\
\text { Comissão } & \\
\text { Editorial } \\
1970)\end{array}$ & \\
\hline $\begin{array}{l}\text { MORAES, Santos } \\
\text { (Colaborador da } \\
\text { seção "Bilbiografia"). }\end{array}$ & & 1965: n. 3. & & \\
\hline $\begin{array}{l}\text { MOREIRA, } \\
\text { Fernando. } \\
\text { (Maranhão). } \\
\text { Colaborador da } \\
\text { seção "Bibliografia". }\end{array}$ & $\begin{array}{l}\text { Escritor. Teatrólogo e contista. Professor de } \\
\text { francês da Faculdade de Filosofia de São Luís. } \\
\text { Obteve o Prêmio de Teatro da sua cidade (1957) } \\
\text { com "Estás em tua casa, Carolina", e o primeiro } \\
\text { lugar no concurso de peças Teatro Duse - } \\
\text { Leitura (1958) com "Reunião de Família. "Inês } \\
\text { sem Pedro" representou o Maranhão no Festival } \\
\text { do Teatro do estudante em Santos. Foi várias } \\
\text { vezes premiado no concurso permanente da } \\
\text { revista A Cigarra. }\end{array}$ & $\begin{array}{l}\text { 1961: n. 4; 1962: n. } \\
\text { 4; 1963: n. 1; 1964: } \\
\text { n. 1, 3. 1965: n. 3, } \\
\text { 4; 1966: n. 1, 4; } \\
\text { 1967: n. 2. }\end{array}$ & & \\
\hline $\begin{array}{l}\text { MOUSSATCHÉ, } \\
\text { Raphael G. }\end{array}$ & & & & $\begin{array}{l}\text { Membro da } \\
\text { Diretoria (1964) }\end{array}$ \\
\hline $\begin{array}{l}\text { MUCCIOLO, } \\
\text { Genaro. } \\
\text { (colaborador da } \\
\text { seção "Bibliografia") }\end{array}$ & & 1965: n. 2. & & \\
\hline $\begin{array}{l}\text { NAFTALI, Ben. } \\
\text { (colaborador da } \\
\text { seção "Bibliografia") }\end{array}$ & & 1970: n. 4. & & \\
\hline NEUFELD, Arnold. & & & & $\begin{array}{lr}\text { Membro } & \text { do } \\
\text { Conselho } & \text { Fiscal } \\
\end{array}$ \\
\hline
\end{tabular}




\begin{tabular}{|c|c|c|c|c|}
\hline & & & & $(1961)$ \\
\hline NEUMANN, Júlio. & & & & $\begin{array}{l}2^{0} \text {. Secretário da } \\
\text { Diretoria (1965) }\end{array}$ \\
\hline $\begin{array}{l}\text { NOVINSKY, Anita. } \\
\text { (colaborador da } \\
\text { seção "Bibliografia") }\end{array}$ & $\begin{array}{l}\text { Historiadora. Professora do Departamento de } \\
\text { História Social da Faculdade de Filosofia, } \\
\text { Letras e Ciências Humanas da Universidade } \\
\text { de Dão Paulo. }\end{array}$ & $\begin{array}{l}\text { 1967: n. 2; 1969: n. } \\
4 .\end{array}$ & $\begin{array}{l}\text { Membro } \quad \text { da } \\
\text { Comissão } \\
\text { Editorial } \\
1969)\end{array}$ & $\begin{array}{l}\text { Bibliotecária } \\
(1965-1970)\end{array}$ \\
\hline $\begin{array}{l}\text { PASTORINO, } \\
\text { Carlos Tôrres. } \\
\text { (colaborador da } \\
\text { seção "Bibliografia") }\end{array}$ & & 1966: n. 3. & & \\
\hline $\begin{array}{ll}\text { PERNIDJI, Joseph } \\
\text { Eskenazi. } \\
\text { 1920/2007 }\end{array}$ & $\begin{array}{l}\text { Advogado, escritor. O carioca Joseph Eskenazi } \\
\text { Pernidji atuava na área de Direito Empresarial. } \\
\text { Foi advogado pro bono da Embaixada de Israel } \\
\text { no Brasil. "Participou de negociações e } \\
\text { elaboração de contratos entre o governo } \\
\text { brasileiro e companhia estrangeiras e brasileiras } \\
\text { que resultaram em obras de grande porte nas } \\
\text { áreas de ferrovias, hidroelétricas, oleodutos, } \\
\text { sistemas de irrigação e financiamento } \\
\text { internacional" }{ }^{215} \text {. Estudioso da história dos judeus } \\
\text { e cristãos-novos da Península Ibérica participou } \\
\text { de congressos e simpósios nacionais e } \\
\text { internacionais a respeito do assunto e publicou } \\
\text { diversos artigos e livros. Entre eles, Das } \\
\text { Fogueiras da Inquisição às Terras do Brasil - a } \\
\text { viagem de 500 anos de uma família judia pela } \\
\text { Imago em 2002, o trabalho "A Inquisição e os } \\
\text { Judeus", publicado no livro Tribunal da História- } \\
\text { Julgando as controvérsias da História Judaica } \\
\text { pela editora Relume Dumará e A Saga dos } \\
\text { Cristãos-Novos, pela Imago, ambos em } 2005 \text {. }\end{array}$ & & $\begin{array}{l}\text { Diretor } \\
\text { Responsável } \\
(1960-1971)\end{array}$ & $\begin{array}{l}10 . \quad \text { Secretário } \\
\text { (1960-1961); } \\
\text { Presidente (1962- } \\
\text { 1971) }\end{array}$ \\
\hline PERPIGNAN, & & & & Membro \\
\hline
\end{tabular}

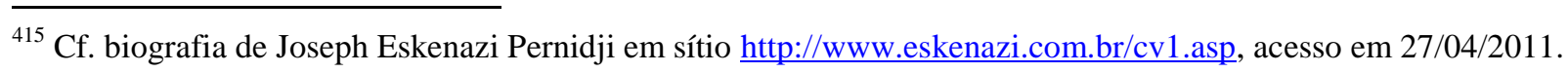




\begin{tabular}{|c|c|c|c|c|}
\hline Maurice. & & & & $\begin{array}{l}\text { Conselho Fiscal } \\
(1965-1970)\end{array}$ \\
\hline $\begin{array}{l}\text { PINKUSS, Fritz }{ }^{416} \\
1905 / 1994 \\
\text { (Egln - Alemanha } \\
\text { /São Paulo - Brasil) }\end{array}$ & $\begin{array}{l}\text { Rabino. Fritz Pinkuss fez sua formação no } \\
\text { Seminário Rabínico de Breslau e na Academia } \\
\text { para as Ciências do Judaísmo. Estudou } \\
\text { psicologia, pedagogia e línguas orientais } \\
\text { doutorando-se em filosofia, na Universidade de } \\
\text { Breslau. Frequentou a Universidade de } \\
\text { Würzburg. Entre 1930-1936 foi rabino do distrito } \\
\text { de Heidelberg onde manteve contato com o } \\
\text { filósofo Karl Jaspers, cuja esposa era judia e } \\
\text { sócia de sua congregação. Ajudou judeus e } \\
\text { inimigos do regime a emigrarem falsificando } \\
\text { documentos e utilizando os fundos das fundações } \\
\text { judaicas no período dos boicotes aos } \\
\text { estabelecimentos judaicos. Passou a viajar a } \\
\text { partir de } 1933 \text { com a intenção de estabelecer } \\
\text { contatos internacionais tendo em vista a situação } \\
\text { que ia se agravando em relação aos judeus. Em } \\
\text { 1936, imigrou para o Brasil radicando-se em São } \\
\text { Paulo onde logo foi procurado por pequenas } \\
\text { comunidades, passando a ofereceu orientação } \\
\text { judaico-religiosa a judeus alemães refugiados, } \\
\text { que começavam a se organizar na América do } \\
\text { Sul. Com o objetivo de construir no Brasil uma } \\
\text { filosofia religiosa segundo os princípios do } \\
\text { judaísmo liberal alemão, Pinkuss iniciou suas } \\
\text { atividades na SIP (Sociedade Israelita Paulista), } \\
\text { precursora da CIP (Congregação Israleita } \\
\text { Paulista), cuja fundação em 1936 recebeu sua } \\
\text { participação ativa. A Congregação Israelita } \\
\text { Paulista (CIP), apoiada financeiramente pelo }\end{array}$ & 1961: n. 1, & 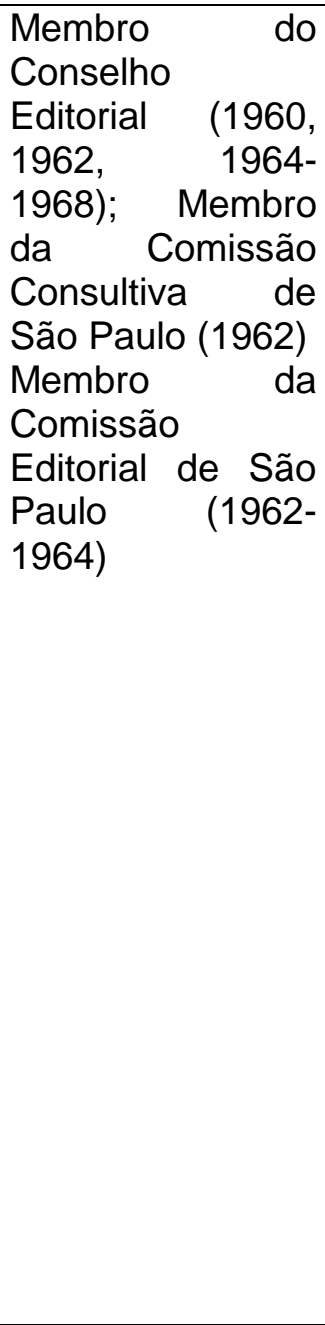 & \\
\hline
\end{tabular}

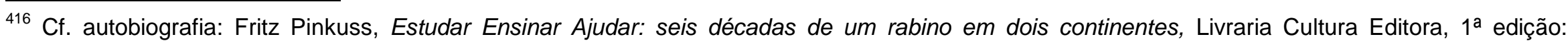
setembro de 1989. 


\begin{tabular}{|c|c|c|c|}
\hline & $\begin{array}{l}\text { American Jewish Joint Distribution Committee } \\
\text { (Joint), foi se consolidando através da assistência } \\
\text { social para a radicação dos recém-chegados } \\
\text { fugidos da perseguição nazista e, em 1946, } \\
\text { recebendo os sobreviventes do holocausto. Foi } \\
\text { rabino da congregação atuando até } 1955 \text { e } \\
\text { rabino-mor até a sua aposentadoria em } \\
10 / 03 / 1987 \text { quando passou a rabino-mor } \\
\text { emérito. Pinkuss tornou-se membro da Central } \\
\text { Conference of American Rabbis e fez parte do } \\
\text { World Union for Progressive Judaism. Lecionou } \\
\text { na Universidade de São Paulo de } 1945 \text { a } 1975 \\
\text { como titular da cadeira de hebraico do } \\
\text { Departamento de Linguistica e Estudos Orientais, } \\
\text { tendo proferido a aula inaugural em } 28 / 03 / 1946 . \\
\text { Foi co-fundador e diretor do Centro de Estudos } \\
\text { Judaicos (CEJ) da Universidade de São Paulo } \\
\text { (USP). Foi nomeado Professor Emérito da } \\
\text { Faculdade Renascença. Recebeu os títulos de } \\
\text { Doutor em Divindade, Honoris Causa, pelo } \\
\text { Hebrew Union College, de Cincinnati, Estados } \\
\text { Unidos e Honorary Fellow, na Universidade } \\
\text { Hebraica de Jerusalém. }\end{array}$ & & \\
\hline $\begin{array}{l}\text { PINTO, José } \\
\text { Alcides. } \\
\text { (Colaborador da } \\
\text { seção "Bilbiografia"). }\end{array}$ & & 1968: n. 3. & \\
\hline PLAUT, Luiz. & & & $\begin{array}{l}2^{\circ} \text {. Tesoureiro da } \\
\text { Diretoria (1965- } \\
\text { 1971). }\end{array}$ \\
\hline $\begin{array}{l}\text { PONTES, Themira. } \\
\text { (colaboradora da } \\
\text { seção "Bibliografia") }\end{array}$ & & 1961: n. 2, & \\
\hline $\begin{array}{l}\text { PROENÇA, Manuel } \\
\text { Cavalcanti. }\end{array}$ & "Biologista" e Crítico. & $\begin{array}{l}\text { 1960: n. } 1 ; 1965: \text { n. } \\
1 .\end{array}$ & \\
\hline
\end{tabular}




\begin{tabular}{|c|c|c|c|c|}
\hline $\begin{array}{l}\text { (Colaborador da } \\
\text { seção "Bilbiografia"). }\end{array}$ & & & & \\
\hline $\begin{array}{l}\text { RATTNER, } \\
\text { Henrique. }\end{array}$ & $\begin{array}{l}\text { Sociólogo. Professor da Universidade de São } \\
\text { Paulo (USP). }\end{array}$ & $\begin{array}{l}\text { 1965: n. 3; 1968: n. } \\
\text { 4; 1969: n. 1, 2; } \\
\text { 1970: n. 1. }\end{array}$ & $\begin{array}{l}\text { Membro } \quad \text { da } \\
\text { Comissão } \\
\text { Editorial } \\
1970)\end{array}$ & \\
\hline REHFELD, Walter. & & & $\begin{array}{l}\text { Membro } \quad \text { da } \\
\text { Comissão } \\
\text { Editorial } \\
1970)\end{array}$ & \\
\hline $\begin{array}{l}\text { REIS, Marcos } \\
\text { Konder. } \\
\text { (colaborador da } \\
\text { seção "Bibliografia") }\end{array}$ & & 1967: n. 3. & & \\
\hline $\begin{array}{l}\text { RIBEIRO, Leo } \\
\text { Gilson }{ }^{417} \\
1929 / 2007 \\
\text { (Varginha (MG)/ } \\
\text { São Paulo (SP) } \\
\text { (Colaborador da } \\
\text { seção "Bilbiografia"). }\end{array}$ & $\begin{array}{l}\text { Jovem ensaísta na época em que começou a } \\
\text { colaborar com seus textos em Comentário. } \\
\text { Escreveu séries de conferências sobre literatura } \\
\text { estrangeira. Foi o primeiro crítico literário da } \\
\text { América Latina a ter um artigo publicado em The } \\
\text { Kenyon Review. Em } 1969 \text { foi descrito como o } \\
\text { único brasileiro formado em Literatura } \\
\text { Comparada na Alemanha (Universidades de } \\
\text { Hamburgo e Heidelberg). Foi leitor de literatura } \\
\text { brasileira junto à Universidade de Heidelberg, } \\
\text { depois de estudar história da arte com Lionello } \\
\text { Venturi na Universitá di Roma e literatura inglesa } \\
\text { na University of California (Berkeley). Crítico } \\
\text { literário no Rio do jornal "Diário de Notícias". } \\
\text { Entre os prêmios que recebeu estão o Esso de } \\
\text { Jornalismo, em 1969, pela matéria A Noite dos } \\
\text { Balões; Prêmio de Melhor Crítico }\end{array}$ & $\begin{array}{l}\text { 1960: n. 1; n. 4; } \\
\text { 1962: n. 3; 1969: n. } \\
\text { 1. }\end{array}$ & & \\
\hline
\end{tabular}

${ }_{417}$ As informações a respeito de Léo Gilson Ribeiro foram retiradas de matéria publicada no jornal O Estado de S. Paulo em 12/01/2007, por ocasião de seu falecimento. A matéria foi reproduzida no site do Obervatório de Imprensa

http://www.observatoriodaimprensa.com.br/artigos. asp? ?cod=415ASP013, acessado em 07/10/2009. 


\begin{tabular}{|c|c|c|c|c|}
\hline & $\begin{array}{l}\text { Jornalístico/Literário do Brasil (1976) pela Editora } \\
\text { Nórdica, Prêmio de Melhor Ensaio, da } \\
\text { Associação Paulista de Críticos de Arte (APCA) } \\
\text { pelo livro O Continente Submerso (1988). } \\
\text { Trabalhou em: Diário de Notícias (assinava a } \\
\text { seção "Caminhos da Cultura"); Correio da Manhã } \\
\text { (Rio de Janeiro); Jornal do Brasil, Jornal da } \\
\text { Tarde; Veja; Caros Amigos; The Kennyon Review } \\
\text { EUA); Christ und Welt (Alemanha); Lever } \\
\text { (Inglaterra). Autor de Cronistas do Absurdo } \\
\text { (1964); O Continente Submerso (1988). }\end{array}$ & & & \\
\hline $\begin{array}{l}\text { RIOS, José Arthur. } \\
\text { (Colaborador da } \\
\text { seção "Bilbiografia"). }\end{array}$ & $\begin{array}{l}\text { Sociólogo brasileiro com títulos nacionais e } \\
\text { estrangeiros. Colaborou por meio de seus } \\
\text { conhecimentos técnicos com diversos governos } \\
\text { estaduais. Foi professor da PUC e Preseidente } \\
\text { do Instituto de Estudos para o Desenvolvimento } \\
\text { Social e Econômico. }\end{array}$ & $\begin{array}{l}\text { 1963: n. 1; 1964: n. } \\
\text { 3, 4; 1966: n. 2; } \\
\text { 1967: n. 1; 1968: n. } \\
\text { 4. }\end{array}$ & & \\
\hline $\begin{array}{l}\text { RODRIGUES, } \\
\text { Jaime. (Colaborador } \\
\text { da Seção } \\
\text { "Bibliografia"). }\end{array}$ & & 1969: n. 2. & & \\
\hline $\begin{array}{l}\text { RÓNAI, Paulo } \\
1907 / 1992 \\
\text { (Budapeste } \\
\text { Hungria/ } \\
\text { Friburgo (RJ) }{ }^{418} \\
\text { (Colaborador da } \\
\text { Seção } \\
\text { "Bibliografia"). }\end{array}$ & $\begin{array}{l}\text { Ensaísta e tradutor judeu. Doutor em Filologia } \\
\text { Latina e Neolatina. Estudou na Sorbonne, na } \\
\text { Alliance Française de Paris e na Università per } \\
\text { Stranieri di Perugia, na Itália. Em Budapeste, } \\
\text { lecionou latim, francês e italiano entre } 1934 \text { e } \\
1940 \text {, e foi professor da Societá Dante Alighieri, } \\
\text { de } 1933 \text { a } 1938 \text {. Foi tradutor e redator da } \\
\text { Nouvelle Revue de Hongrie, além de colaborar } \\
\text { em diversos jornais e revistas húngaros e } \\
\text { franceses. Estudou e aprendeu sozinho a língua }\end{array}$ & $\begin{array}{l}\text { 1960: n. 1, 2, 3; } \\
\text { 1961: n. 1, 2, 3; } \\
\text { 1962: n. 2, 3, 4; } \\
\text { 1963: n. 1. }\end{array}$ & $\begin{array}{lr}\text { Secretário } & \text { da } \\
\text { Redação } & (1960- \\
\text { 1962). } & \end{array}$ & \\
\hline
\end{tabular}

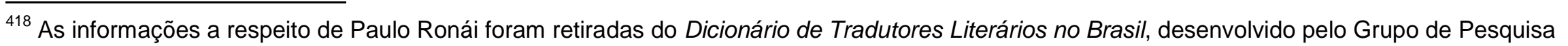
Literatura Traduzida do Núcleo de Tradução da UFSC, consultado em http://www.dicionariodetradutores.ufsc.br/pt/index.htm, acessado em 22/02/2011. 


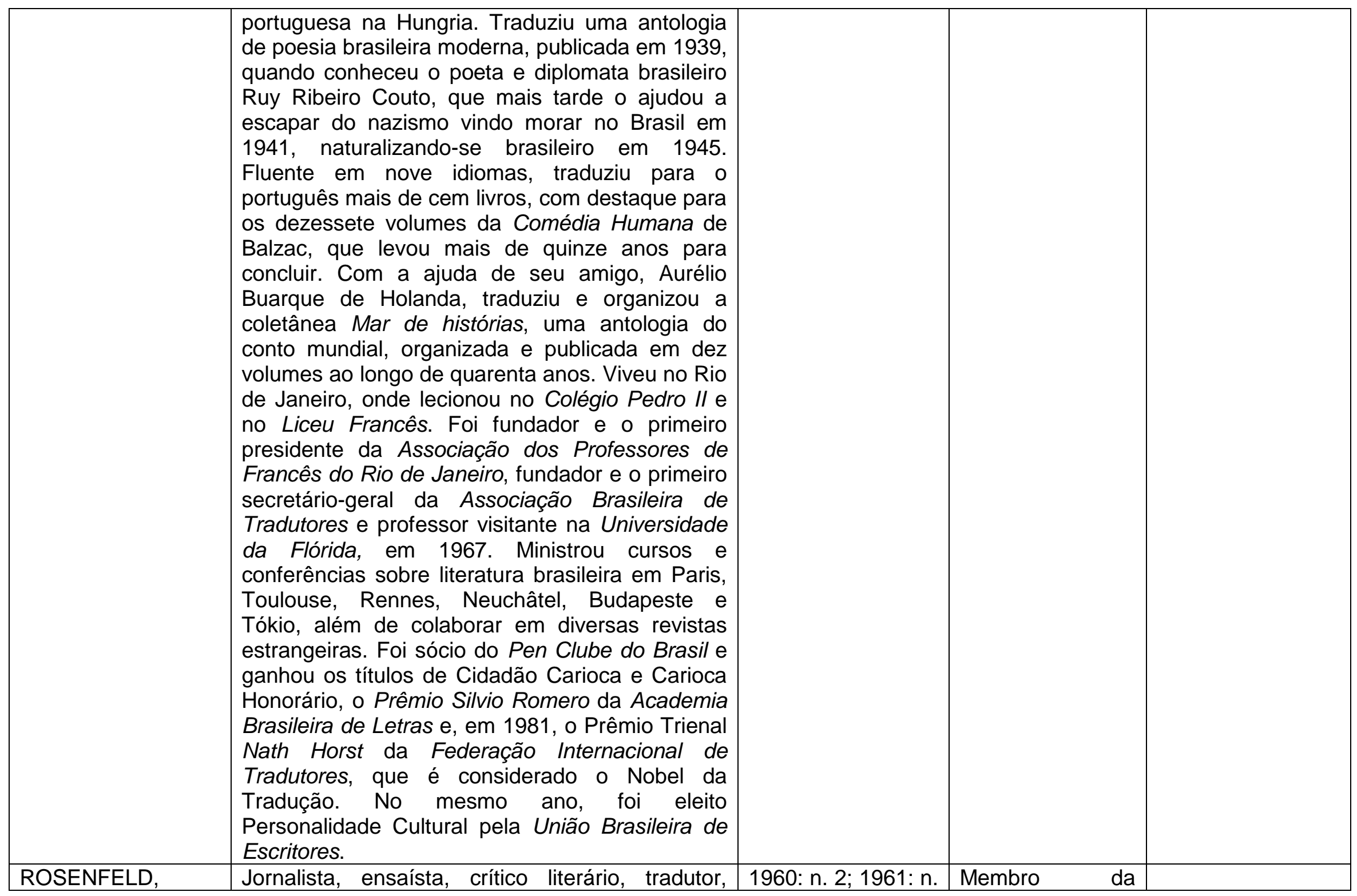




\begin{tabular}{|c|c|c|c|c|}
\hline $\begin{array}{l}\text { Anatol. } \\
1912-1973 \\
\text { (Berlim/Alemanha - } \\
\text { São Paulo/Brasil) }\end{array}$ & $\begin{array}{l}\text { poeta, professor de filosofia e de estética do } \\
\text { teatro. Intelectual de origem judaica. Estudou } \\
\text { letras alemãs filosofia e história na Universidade } \\
\text { de Berlim (1930-34). Radicou-se no Brasil em } \\
\text { 1937, vindo para São Paulo. Trabalhou como } \\
\text { colono numa fazendo do interior do estado, } \\
\text { lustrador de portas no Paraná e vendedor de } \\
\text { gravatas Baeck. Escreveu regularmente no } \\
\text { Suplemento Literário do jornal O Estado de São } \\
\text { Paulo, além de colaborar na Crônica Israelita. } \\
\text { Entre os anos 1950-1970 ocupou lugar de } \\
\text { destaque na vida cultural paulistana, enquanto } \\
\text { intermediário entre as culturas brasileira e alemã. } \\
\text { e publicou vários ensaios na Revista Brasileira de } \\
\text { Filosofia. Traduziu Thomas Mann, Brecht, Kafka, } \\
\text { Mário de Andrade e Augusto dos Anjos. Deixou } \\
\text { estudos sobre o moderno teatro alemão e } \\
\text { reflexões sobre a estrutura da obra literária, } \\
\text { pensamento literário, antissemitismo, cultura } \\
\text { popular brasileira, entre outros assuntos. } \\
\text { Publicou: Texto e contexto (1969) e Teatro } \\
\text { Alemão (1969). }\end{array}$ & $\begin{array}{l}\text { 4; 1962: n. 4; 1965: } \\
\text { n. 2, 4; 1969: n. 2, } \\
4 ; 1970: \text { n. } 2 .\end{array}$ & 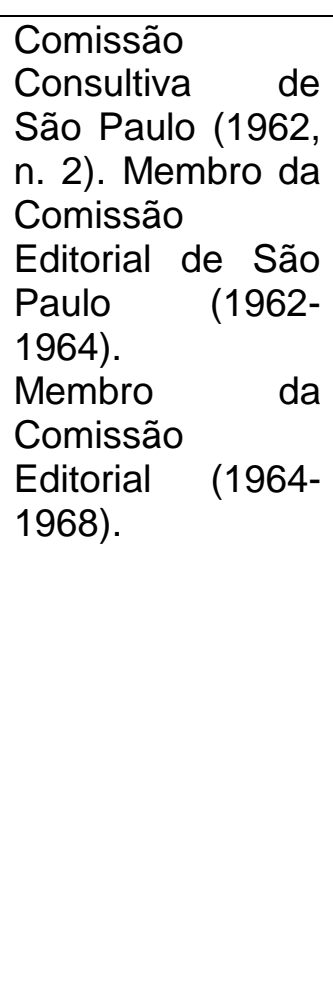 & \\
\hline ROTSTEIN, Jaime. & $\begin{array}{l}\text { Foi Presidente da Associação Brasileira } \\
\text { deEengenharia e Saneamento e da Câmara de } \\
\text { Comércio e Indústria Brasil-Israel. Foi membro do } \\
\text { Conselho Diretor do Clube de Engenharia. } \\
\text { Publicou trabalhos em jornais e revistas. }\end{array}$ & $\begin{array}{l}\text { 1965: n. 4; 1966: n. } \\
3\end{array}$ & & $\begin{array}{l}1^{\circ} \text {. Secretário } \\
(1962-1971)\end{array}$ \\
\hline SABINO, Fernando. & & 1961: n. 2 & & \\
\hline SALGADO, Paulo. & & & Secretário (1971) & \\
\hline $\begin{array}{l}\text { SCHAALMAN, } \\
\text { Ernesto. }\end{array}$ & & & & $\begin{array}{lr}\text { Membro } & \text { do } \\
\text { Conselho } & \text { Fiscal } \\
(1971) & \end{array}$ \\
\hline $\begin{array}{l}\text { SCHIFNAGEL, } \\
\text { Isaac. }\end{array}$ & & & & $\begin{array}{l}2^{2} \text { Secretário } \\
(1966-1971)\end{array}$ \\
\hline SCHLESINGER, & & & & Membro \\
\hline
\end{tabular}




\begin{tabular}{|c|c|c|c|c|}
\hline Jony. & & & & $\begin{array}{lr}\text { Comissão } & \text { de } \\
\text { Programação } & \text { e } \\
\text { Planejamento } & \\
(1971) & \end{array}$ \\
\hline $\begin{array}{l}\text { SCHNEIDER, } \\
\text { Eliezer. } \\
\text { (colaborador da } \\
\text { seção "Bibliografia") }\end{array}$ & & 1967: n. 1. & & \\
\hline $\begin{array}{l}\text { SCHNEIDERMAN, } \\
\text { Bóris. } \\
1917- \\
\text { (Úman - Ucrânia) } \\
\text { (colaborador da } \\
\text { seção "Bibliografia") }\end{array}$ & $\begin{array}{l}\text { Tradutor. Imigrou para o Brasil aos oito anos de } \\
\text { idade com os pais em 1925. Formou-se pela } \\
\text { Escola Nacional de Agronomia. Fez a campanha } \\
\text { da Itália na Força Expedicionária Brasileira (FEB). } \\
\text { Começou a traduzir autores russos em } 1944 \text { e a } \\
\text { colaborar na imprensa a partir de } 1957 \text {. Entre os } \\
\text { escritores que traduziu estão: Fiódor Dostoiévsky, } \\
\text { Anton Tchekhov e vários poetas. } \\
\text { Schaneidermann estimulou o estudo de tradução } \\
\text { de obras da literatura russa. Não fez formação } \\
\text { acadêmica na área de Letras, porém foi o } \\
\text { precursor do curso de Língua e Literatura Russa } \\
\text { da Universidade de São Paulo onde obteve o } \\
\text { título de Doutor e Livre-docente, sendo professor } \\
\text { dês } 1960 \text {. }\end{array}$ & $\begin{array}{l}\text { 1965: n. 1; 1969: n. } \\
4 .\end{array}$ & $\begin{array}{lr}\text { Membro } & \text { da } \\
\text { Comissão } & \\
\text { Consultiva } & \text { de } \\
\text { São } & \text { Paulo } \\
(1962) & \text { Membro } \\
\text { da } & \text { Comissão } \\
\text { Editorial } & \text { de São } \\
\text { Paulo } & (1962- \\
1964) . & \text { Membro } \\
\text { da } & \text { Comissão } \\
\text { Editorial } & (1964- \\
\text { 1970) } & \end{array}$ & \\
\hline SCHWABE, Peter. & & & $\begin{array}{lr}\text { Membro } & \text { do } \\
\text { Conselho } & \\
\text { Editorial } & (1960- \\
1964) . & \text { Membro } \\
\text { da } & \text { Comissão } \\
\text { Editorial } & (1964- \\
1968) . & \end{array}$ & $\begin{array}{l}\text { Bibliotecário } \\
\text { (1960); Diretor } \\
\text { Cultural (1961); } 2^{\circ} \\
\text { Vice - Presidente } \\
(1962-1971)\end{array}$ \\
\hline SELOVICZ, Fiszel. & & & & $\begin{array}{lr}\text { Membro } & \text { do } \\
\text { Conselho } & \text { Fiscal } \\
(1965-1970) & \end{array}$ \\
\hline SICHEL, Walter. & & & & $\begin{array}{lr}\text { Membro } & \text { do } \\
\text { Conselho } & \text { Fiscal }\end{array}$ \\
\hline
\end{tabular}




\begin{tabular}{|c|c|c|c|c|}
\hline & & & & (1960). \\
\hline $\begin{array}{l}\text { SILVA, Fernando Py } \\
\text { de Mello e. } \\
1935- \\
\text { (Rio de Janeiro - } \\
\text { Brasil) } \\
\text { (colaborador da } \\
\text { seção "Bibliografia") }\end{array}$ & $\begin{array}{l}\text { Tradutor. Colunista Literário (Diário de } \\
\text { Petrópolis). Formou-se em Direito. Costumava } \\
\text { redigir resenhas para Comentário. E para a } \\
\text { revista Cadernos Brasileiros. Publicou, entre } \\
\text { outros: Aurora de vidro, Livraria São José, Rio de } \\
\text { Janeiro, 1962; Vozes do corpo, Editora Fontana, } \\
\text { Rio de Janeiro, 1981; Chão da crítica, Francisco } \\
\text { Alves, Rio de Janeiro, 1984; e Antiuniverso, Sette } \\
\text { Letras, Rio de Janeiro, 1994.. }\end{array}$ & $\begin{array}{l}\text { 1961: n. 4; 1962: } \\
\text { ns. 1, 4; 1964: ns. } \\
\text { 2, 3, 4; 1965: n. 1, } \\
\text { 2, 3; 1966: n. 3, 4. }\end{array}$ & & \\
\hline $\begin{array}{l}\text { SPICEHANDLER, } \\
\text { Ezra. }\end{array}$ & & $\begin{array}{l}\text { 1961: n. 4;1962: n. } \\
1,\end{array}$ & & \\
\hline STEINBERG, José. & $\begin{array}{l}\text { Escrevia poesias. Algumas foram publicadas nos } \\
\text { suplementos literários da Guanabara. }\end{array}$ & & $\begin{array}{lr}\text { Assistente } & \text { da } \\
\text { Direção: } & (1963- \\
\text { 1968) }\end{array}$ & \\
\hline STRAUSS, Ernesto. & & & & $\begin{array}{lr}\text { Membro } & \text { da } \\
\text { Comissão } & \text { de } \\
\text { Programação } & \text { e } \\
\text { Planejamento } & \\
(1971) & \\
\end{array}$ \\
\hline $\begin{array}{l}\text { STRAUSS, Gerald. } \\
\text { (colaborador } \\
\text { internacional da } \\
\text { seção "Bibliografia") }\end{array}$ & & 1961: n. 2, & & \\
\hline TELES, Mário. & & 1961: n. 3, & & \\
\hline $\begin{array}{l}\text { TREVOR-ROPER, } \\
\text { H. R. (colaborador } \\
\text { internacional da } \\
\text { seção "Bibliografia") }\end{array}$ & $\begin{array}{l}\text { Historiador, especialista em História Moderna } \\
\text { Britânica e Alemanha nazista. Anticomunista. } \\
\text { Contribuía também na revista Encounter do } \\
\text { Congress for Culture Freedom. }\end{array}$ & 1960: n. 1; & & \\
\hline $\begin{array}{l}\text { VARGAS, Maria } \\
\text { Thereza. } \\
\text { (colaboradora da } \\
\text { seção "Bibliografia") }\end{array}$ & & 1969: n. 1 & & \\
\hline $\begin{array}{l}\text { VELHO, Octavio } \\
\text { Alves. (colaborador }\end{array}$ & $\begin{array}{l}\text { Tenente-Coronel. Foi professor de Português da } \\
\text { Academia Militar de West Point. Escreveu }\end{array}$ & 1961: ns. 1, 3. & & \\
\hline
\end{tabular}




\begin{tabular}{|c|c|c|c|c|}
\hline $\begin{array}{ll}\text { da } & \text { seção } \\
\text { "Bibliografia") }\end{array}$ & $\begin{array}{l}\text { trabalhos de literatura militar. Tradutor de Erich } \\
\text { Fromm, R. Mc Iver, David Lilenthal, Jay Rumney, } \\
\text { Joseph Meier, Howard R. Bowen, Karen Horney, } \\
\text { James Stockley, W. W. Rostow, Karl Mannheim e } \\
\text { outros. }\end{array}$ & & & \\
\hline VENTURA, Hélio. & & & & $\begin{array}{lr}\text { Membro } & \text { da } \\
\text { Comissão } & \text { de } \\
\text { Programação } & \text { e } \\
\text { Planejamento } & \\
(1971) & \\
\end{array}$ \\
\hline $\begin{array}{l}\text { WAITZFELDER, } \\
\text { Joseph. }\end{array}$ & & & & $\begin{array}{ll}\text { Secretário } & \text { do } \\
\text { Conselho } & \\
\text { Deliberativo } & \\
(1960-1970) & \end{array}$ \\
\hline WALD, Arnold. & & & & $\begin{array}{l}\text { Bibliotecário } \\
(1962-1964)\end{array}$ \\
\hline $\begin{array}{lr}\text { XAVIER, } & \text { Raul. } \\
\text { (colaborador } & \text { da } \\
\text { seção "Bibliografia") }\end{array}$ & & $\begin{array}{l}\text { 1966: n. 3, 4; 1967: } \\
\text { n. 1, 3; 1968: n. 2, } \\
\text { 3. }\end{array}$ & & \\
\hline ZAPLER, Balfour. & & & $\begin{array}{l}\text { Diretor Editorial } \\
(1969-1970)\end{array}$ & \\
\hline ZAPLER, Flora. & & & $\begin{array}{l}\text { Diretora } \\
\text { Comercial (1969); } \\
\text { Relações } \\
\text { Públicas (1970) }\end{array}$ & \\
\hline
\end{tabular}




\begin{tabular}{|c|c|c|}
\hline \multicolumn{3}{|c|}{ Comentário: Seção "Sôbolos rios que vão..." - cultura judaica - excertos } \\
\hline Autor & Breve referência biográfica & Tema/ Título \\
\hline $\begin{array}{l}\text { Itzchak Leib } \\
\text { Perez } \\
\text { ou Isaac Leão } \\
\text { Peretz } \\
(1851-1915)^{419}\end{array}$ & $\begin{array}{l}\text { Reconhecido novelista da literatura judia. Nascido na Polônia, } \\
\text { escreveu em iídiche e hebraico sobre o hassidismo e o gueto de } \\
\text { Varsóvia. Seus contos retratavam os costumes e as tradições de } \\
\text { seu povo. Escreveu poesia também. Detido em } 1910 \text { pelo governo } \\
\text { russo ao queixar-se da amarga sorte dos judeus poloneses. }\end{array}$ & $\begin{array}{l}\text { 1. "'Neila' no Inferno", In: Comentário, Ano I, } \\
\text { nó. 4, 1960, pp. 71-74. } \\
\text { 2. "Prodígios do Mar", In: Comentário, Ano } \\
\text { III, no. 3, seção “contos", 1962, pp. 260-263. }\end{array}$ \\
\hline $\begin{array}{l}\text { Malbim } \\
(1809-1879)^{420}\end{array}$ & $\begin{array}{l}\text { Rabino do leste europeu que produziu diversos trabalhos literários, } \\
\text { entre eles, um Comentário minucioso da Bíblia. }\end{array}$ & $\begin{array}{l}\text { 1. “O Amor ao Próximo", In: Comentário, Ano } \\
\text { I, no. 1, 1960, pp. } 77-78 \text {. }\end{array}$ \\
\hline $\begin{array}{l}\text { Sholem } \\
\text { Aleichem } \\
(1859 / 1916)\end{array}$ & $\begin{array}{l}\text { O consagrado escritor e humorista russo, Salomão Rabinovich, } \\
\text { dedicou-se ao comércio e mais tarde à literatura. Sua obra de } \\
\text { contos, novelas e dramas é vasta e ele foi descrito como um } \\
\text { escritor cujo "estilo tem o calor, a facilidade e a influência } \\
\text { espontânea dos grandes escritores do povo que escreveram para o } \\
\text { povo." } 21 \text {. }\end{array}$ & $\begin{array}{l}\text { 1. "Como me tornei escritor - Contribuição } \\
\text { para minha biografia". In: Comentário, Ano I, } \\
\text { nº. } 1,1960 \text {, pp. } 73-76 \text {. }\end{array}$ \\
\hline $\begin{array}{l}\text { Theodor Herzl } \\
(1860-1904)\end{array}$ & $\begin{array}{l}\text { Líder do sionismo político nascido em Budapeste. Foi o } \\
\text { emblemático Caso Dreyfus que o moveu. Herzl lutou pela causa } \\
\text { sionista pelas vias literária, política e diplomática. }\end{array}$ & $\begin{array}{l}\text { 1. "Autobiografia", In: Comentário, Ano I, no. } \\
\text { 4, 1960, pp. 68-70. }\end{array}$ \\
\hline
\end{tabular}

\footnotetext{
$\overline{419}$ Informações biográficas retiradas do texto na revista e de Carlos Ortiz e Jacó Guinsburg. Antologia Judaica, São Paulo, Editora Rampa Ltda, 1948, p. 224.

420 Informações biográficas retiradas de In: Comentário, Ano I, no .1 , janeiro, fevereiro e março de 1960, p. 77.

${ }^{421}$ Carlos Ortiz e Jacó Guinsburg. Op. cit., 1948, p. 242.

422 Ídem, p. 266.
} 